Министерство образования и науки Республики Адыгея Федеральное государственное бюджетное образовательное учреждение высшего образования «Адыгейский государственный университет» Экономический факультет

\title{
ПРОБЛЕМЫ И ПЕРСПЕКТИВЫ \\ СОЦИАЛЬНО-ЭКОНОМИЧЕСКОГО \\ РАЗВИТИЯ РЕГИОНОВ ЮГА РОССИИ
}

III Всероссийская научно-практическая конференция (24 ноября 2016 г., г. Майкоп)

СБОРНИК НАУЧНЫХ ТРУДОВ

Майкоп

2017 
Министерство образования и науки Республики Адыгея Федеральное государственное бюджетное образовательное учреждение высшего образования «Адыгейский государственный университет»

Экономический факудьтет

\section{Троблемы и перспективы сочиально-экономического развития регионов Юга России}

III Всероссийская научно-практическая конференция (24 ноября 2016 г., г. Майкоп)

СБОРНИК НАУЧНЫХ ТРУДОВ

Майкоп

2017 
УДК 332.142(470.6)

ББК 65.04(235.7)л0

$\Pi 78$

Публикуется по решению научно-методического совета экономического факультета Адыгейского государственного университета

\section{РЕЦЕНЗЕНТЫ:}

доктор экономических наук, профессор, заведующий кафедрой экономики

ЧОУ ВО Южный институт менеджмента

Ермоленко А. .

доктор экономических наук, профессор кафедры производственного менеджмента и экономики отраслей народного хозяйства

ФГБОУ ВО «Кубанский государственный технологический университет»

Прохорова В.В.

Научный редактор-д.э.н., профессор, декан экономического факультета Тамов А.А.

Члены редакционной коллегии: д.п.н., проф. Шелехова Л.В.;

к.э.н., доц. Тхагапсо Р.А.;

к.э.н., доц. Силина Т.А.,

Бабалян Э.Б.

П78 Проблемы и перспективы социально-экономического развития регионов Юга России [Электронный ресурс] : сборник научных трудов по материалам III Всероссийской научно-практической конференции / под науч. редакцией А.А. Тамова- Майкоп: ЭлИТ, 2017.

ISBN 978-5-9909192-9-7

doi 10.18411/elit-040/

В сборник вошли результаты актуальных научных исследований ученых, докторантов, преподавателей, аспирантов и студентов по материалам III Всероссийской заочной научно-практической конференции «Проблемы и перспективы социально-экономического развития регионов Юга России» (Адыгейский государственный университет, Майкоп).

Сборник предназначен для преподавателей и студентов экономических специальностей. Может использоваться в учебном процессе, в том числе при подготовке аспирантов, магистров и бакалавров в целях углубленного рассмотрения соответствующих проблем.

УДК 332.142(470.6)

ББК 65.04(235.7)л0

Сборник научных трудов подготовлен по материалам, представленным в электронном виде, сохраняет авторскую редакцию, всю ответственность за содержание несут авторы.

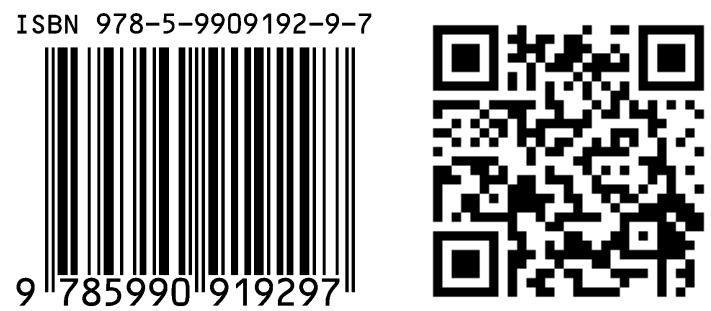

(C) ФГБОУ ВО «Адыгейский государственный университет», 2016

(C) Коллектив авторов, 2016

(C) Оформление электронного издания ООО «ЭлИТ», 2017 


\section{ОГЛАВЛЕНИЕ}

РАЗДЕЛ 1. РЕГИОНАЛЬНАЯ ЭКОНОМИКА

Аджайи A.O. Потенциал целевой среднесрочной программы как инструмента реализации региональных приоритетов.

Алыев Н.А. оглы Обоснование стратегии управления конкурентными преимуществами региона. 12

Берестенева О.В. Стратегические аспекты формирования субрегиональных кластеров в республиках Северного Кавказа 16

Картамышев В.В., Тхакушинова С.А. Зарубежный опыт развития государственно-частного партнерства .. 20 Картамышев В.В., Тхакушинова С.А. Оценка результатов деятельности субъектов малого и среднего предпринимательства в Республике Адыгея.

Ковалева М.К. «Олимпийское наследие» как фактор повышения аттрактивности сочинской дестинации .. 33 Меджидов Ш.М. Особенности и проблемы экономического сотрудничества Краснодарского края и Республики Адыгея 36

Мукба А.В. Сравнительный анализ региональных программ социально-экономического развития Республики Адыгея .

Мырадов С.Б. Особенности диверсификации экономики как инструмента сбалансированного развития региона 43

Услистый В.И. Имидж муниципального образования, как один из ключевых аспектов на пути к экономическому развитию региона.

Устова Г.М. Тенденции формирования внутрирегиональных социально-экономических различий 50

Хамуков А.А. Инвестиционная привлекательность муниципального образования «Город Майкоп» и меры, принимаемые для ее повышения. 53

Хамуков А.А. Основные аспекты инвестиционной привлекательности муниципального образования. ........ 58

Юрченко Е. А. Региональные аспекты кадровой политики в системе государственного управления.............63

РАЗДЕЛ 2. ЭКОНОМИКА И УПРАВЛЕНИЕ ПРЕДПРИЯТИЯМИ, ОТРАСЛЯМИ, КОМПЛЕКСАМИ ........................ 68

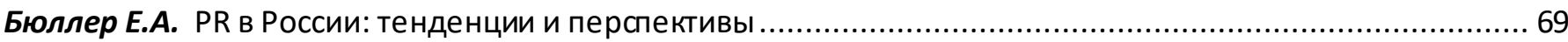

Гидзова 3.А. Основные тенденции развития денежно-кредитной сферы Республики Адыгея..................... 72

Гидзова 3.А. Роль ипотечного кредитования в развитии рынка жилья Республики Адыгея .......................... 76

Ковалева М.К., Юрханян К.А. Сферауслуг Краснодарского края в условиях ухудшения общеэкономической конъюнктуры.

Кубашичев А.А. Государственно-частное партнерство, как новая форма взаимоотношения государства и бизнеса

Кубашичев А.А. Государственно-частное партнерство в Республике Адыгея.

Мамсирова A. A. Сетевой формат как инструмент обеспечения устойчивости торгового бизнеса в условиях нестабильной внешней среды

Оганнисян М.А. Актуальные вопросы совершенствования рекламной компании применительно к ООО «МПК» пивоваренный завод «Майкопский». 
Оганнисян М.А. Проблемы и перспективы развития рынка мобильного маркетинга в России

Татлок А.P, Шелеова Л.В. Меры государственной поддержки малого и среднего предпринимательства в современной экономике

Тлехатук Ф.Р. Проблемы государственного регулирования развития агропромышленного комплекса.....107

Тлехатук Ф.Р. Территориально-отраслевые особенности развития АПК Республики Адыгея ......................110

Хатков М.А. Формирование бизнес-групп и их воздействие на экономику страны...............................115

Хуранов А.А. Проблемы и перспективы развития сети многофункциональных центров предоставления государственных и муниципальных услуг в Республике Адыгея.

Андрюхина Д.В., Бореева Е.Р. Проблемы аудиторской деятельности в РФ: сущность и пути ре шения.

Андрюхина Д.В., Бореева Е.Р. Сравнительный анализ российского и международного подходов к учету научно-исследовательских и опытно-конструкторских работ .....

Бекирова К.Н., Тхаркахова М.Н. Международный подходк подготовке финансовой отчетности организаций строительной отрасли

Бжунаева А.М., Ордынская М.E. Амортизация активов как экономическая категория. .138

Бзегежева С.А. Актуальные вопросы пенсионного обеспечения в современных условиях .142

Кондратенко А.В. Классификация и учет затрат на благоустройство территории и приобретение многолетних насаждений в санаторно-курортных организациях и организациях гостиничного бизнеса.....147

Костюкова И.Н., Луговский Д.В. Отраслевые особенности индустрии общественного питания и их влияние на систему бухгалтерского учета

Костюкова И.Н., Луговский Д.В., Тхагапсо Р.А. Понятие, классификация и учет специальной оснастки и специальной одежды.

Лафишева А.А., Нехай З.А. Значение и первые результаты внедрения пилотного проекта «Прямые выплаты»...

Мирзова С.Г. Пользователи аудита и анализ их информационных потребностей. .169

Намоев А.P. Особенности бухгалтерского учета добавочного капитала организации

Науменко Н.В. Понятие, роль и принципы формирования и раскрытия учетной политики в рыночной экономике

Нехай А.X. Финансово-экономические аспекты развития туризма в Республике Адыгея .183

Ордынская М.Е., Нестерова И.Л. Анализ законодательной базы по учету расходов будущих периодов ...187 Охезина К.Ю., Погосян С.А. Особенности формирования продажных цен на продукцию общественного питания

Погосян С.A. Специфика организации и ведения бухгалтерского учета на предприятиях пищевой промышленности.

Путренко А.В., Ордынская М.Е. Анализ нормативно-правовой базы по учету резервов..........................198

Самохвалова А.В. Особенности учета операций с финансовыми инструментами ................................203

Сидорук Ю.В., Погосян С.А. К вопросу учета затрат на производство продукции общественного питания..206

Стакозов А.В. Бухгалтерский учет основных средств в гостинично-ресторанном бизнесе. .210 
Тхакушинова С.A. Об особенности применения территориальных различий налогообложения в налоговой оптимизации (на примере ЕНВД в гостиничном бизнесе) .215

Хатков М.А. Модернизация контрольно-кассовой техники и ее применение .....................................218

Хашиг И.О., Бекирова К.Н. Бухгалтерский учет выручки: международный подход................................222

Хоретлева Б.М. Взаимодействие аудита и экономического анализа …...........................................227

Хоретлева Б.М., Мирзова С.Г. Особенности финансовой отчетности в зарубежных странах.....................231

Хоретлева Б.М., Мирзова С.Г. Некоторые аспекты бухгалтерской отчетности малых форм бизнеса

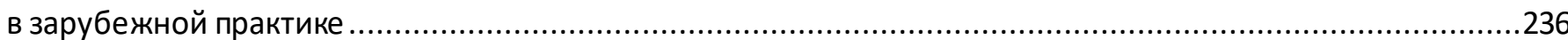

РАЗДЕЛ IV. АКТУАЛЬНЫЕ ВОПРОСЫ ЭКОНОМИЧЕСКОЙ ТЕОРИИ

Пшиканокова Н. И., Шалатов В. В. Основные принципы, направления и императивы использования механизма государственно-частного партнерства на мезоуровне .241

Хатков М.А. Монетарное стимулирование деловой активности малого и среднего бизнеса. .245

Шитухина Н.С. Информационные услуги как важнейшая форма сервисной деятельности в современных условиях

РАЗДЕЛ 5. ПРОБЛЕМЫ ЭКОНОМИЧЕСКОГО ОБРАЗОВАНИЯ В ВЫСШЕЙ ШКОЛЕ В УСЛОВИЯХ ИННОВАЦИОННОГО РАЗВИТИЯ.

Кочконян B.A. Некоторые аспекты PR-стратегии по продвижению на рынке образовательных услуг (на примере факультета) .254

Оганнисян М.А. Рольстудентов экономического факультета АГУ в профессиональном ориентировании абитуриентов.

Шелехова Л.В., Глебова К.А. Нетворкинг как сетевая форма организации экономического образования...262

РАЗДЕЛ 6. ЭКОНОМИКА ТРУДА И УПРАВЛЕНИЕ ПЕРСОНАЛОМ .268

Бюллер Е.А., Сиюхова А.К, Чич И.В. Мотивация персонала в условиях кризиса .269 


\section{РАЗДЕЛ I}

РЕГИОНАЛЬНАЯ ЭКОНОМИКА 


\title{
ПОТЕНЦИАЛ ЦЕЛЕВОЙ СРЕДНЕСРОЧНОЙ ПРОГРАММЫ КАК ИНСТРУМЕНТА РЕАЛИЗАЦИИ РЕГИОНАЛЫНЫХ ПРИОРИТЕТОВ
}

Аджайи Афолаби Олатунджи

Магистрант 2 курса, Адыгейский государственный университет, г. Майкоп

Научный руководитель: Тамов А.А.

д.э.н., профессор Адыгейский государственный университет, г. Майкоп

\begin{abstract}
Аннотация. В статье рассматриваются возможности иелевой среднесрочной программы как инструмента реализации различных региональных приоритетов. Особое внимание уделено возможностям программного инструмента по обеспечению конкурентоспособности Республики Адыгея.
\end{abstract}

Ключевые слова: программа, региональная экономика, конкурентоспособность, конкурентные преимущества, стратегия, приоритеть.

\section{POTENTIAL TARGET AS A MEDIUM-TERM PROGRAMME IMPLEMENTATION INSTRUMENT REGIONAL PRIORITIES}

\author{
Adzhayn Afolabi Olatundzhi \\ Undergraduate of 2 courses, Adyghe State University, Maikop \\ Supervisor: Tamov A.A. \\ PhD, professor of Adyghe State University, Maikop
}

\begin{abstract}
The article deals with the possibility of mid-term target program as a tool for the implementation of the different regional priorities. Particular attention is paid to the possibilities of a software tool to ensure the competitiveness of the Republic of Adygea.

Keywords: program, regional economy, competitiveness, competitive advantage, strategy, priorities.
\end{abstract}

Отсутствие стратегической направленности в деятельности органов региональной власти заметно снижает эффективность принимаемых управленческих решений, что не позволяет поэтапно достигать намеченных стратегических и тактических целей его развития. В связи с этим в последние годы в субъектах федерации все больше внимания стали уделять различным инструментам регулирующего воздействия, в числе которых наиболее эффективным является программно-целево й метод.

Региональные среднесрочные целевые программы представляют собой согласованный и увязанный по ресурсам, исполнителям и срокам комплекс различных мероприятий, реализуемых при активной поддержке органов ре- гионально й власти и обеспечивающих эффективное решение важнейших задач развития, Они служат наиболее эффективным инструментом для стратегического управления региональной экономикой, поскольку использование программно-целевого метода позволяет осуществить централизацию действий при формировании стратегии социально-экономического развития региона, концентрацию его ресурсов на решение приоритетных проблем, включая проблемы обеспечения конкурентоспособности региона.

Региональное целевое программирование как инструмент прямого воздействия органов власти на экономику обеспечивает сочетание принципов саморегулирования и целенаправленности ее развития. В современ- 
ных условиях новая сущность целевых программ состоит в том, что они воплощают в себе синтез «жесткого плана» и «свободного рынка», когда строго направленная хозяйственная и иная деятельность осуществляется и стимулируется на коммерческой основе. При этом обязательность выполнения всеми участниками целевой программы запланированных мероприятий обеспечивается не директивностью заданий, как это было в период планово-директивной экономики, а договорами в сочетании с системой экономических стимулов [1].

Использование программно-целевого подхода при формировании региональной экономической политики реализует программнопроблемный аспект, являясь эффективным средством централизованного управления решением крупных проблем на основе определения целей, приоритетных направлений, формирования целевых заданий, выражаемых в соответствующих показателях, определения потребности в ресурсах, разработку мер для реализации поставленных целей.

В условиях посткризисного развития удерживать существенные конкурентные преимущества смогут только те регионы, где региональная администрация проводит хорошо продуманную структурную политику. Поэтому при реализации региональных проблем структурного характера возникает необходимость кардинального изменения неблагоприятных пропорций, структуры, тенденций развития экономики и социальной сферы, что может быть достигнута наибольшая результативность от применения программного инструмента.

Программы могут применяться как эффективное средство целенаправленного воздействия органов регионального управления структурно-динамическими процессами независимо от форм собственности, и в этом качестве они сегодня особенно востребованы [2].

Преимущества программно-целевого метода управления структурно-динамическ им и процессами в экономике региона характеризуют следующие особенности принципиального характера:

- индикативный характер программы, сроки и результативность реализации которой находятся в прямой зависимости от ее обеспеченности необходимыми материальными и финансовыми ресурсами;

- системный характер основных целей и задач программы по решению сложных структурно-динамических проблем развития экономики и социальной сферы региона;

- способность конщентрировать материальные и финансовые ресурсы на решение приоритетных задач социально-экономического развития региона, от которых зависит поступательное развитие экономики и рост ее конкурентоспособности;

- возможность использовать эффект мультипликатора при целевом использовании ограниченных бюджетных ресурсов за счет дополнительного привлечения внебюджетных средств, собственных средств заинтересованных государственных и коммерческих предприятий, банковского кредита и иных привлеченных средств потенциальных отечественных и иностранных инвесторов;

- возможность эффективно сочетать в ходе государственного управления развитием региональной экономики программно-целево й метод управления с методами регионального прогнозирования и индикативного планирования;

- потенциальная возможность обеспечения действенного общественного контроля при формировании целей и задач программного развития и использовании финансовых ресурсов при реализации программы. 
В посткризисных условиях создавать и удерживать существенные конкурентные преимущества смогут только те регионы, где региональная администрация проводит хорошо продуманную целенаправленную политику, направленную на обеспечение конкурентоспособности региона. В связи с этим представляет интерес оценка того, насколько были учтены проблемы усиления конкурентных позиций Республики Адыгея в двух региональных среднесрочных программах еe coциально-экономического развития, реализованных в 1997-2000 гг. и 2004-2008 гг. [3,4].

Следует подчеркнуть, что в сложнейших предкризис ных условиях 1997 года, когда была разработана первая из рассматриваемых Программ, задача повышения конкурентоспособности региона прямо не ставилась, В ней акцент был сделан на стабилизацию производства в основных отраслях экономики республики, повышение ее финансового потенциала, снижение дотационности регионального бюджета, что, в конечном счете, могло позитивно сказаться и на конкурентоспособности региона.

В Программе экономического и социального развития Адыгеи на 2004-2008 гг., разработанной в период восстановительного роста экономики, повышение конкурентоспособности региона было отнесено к числу важнейших программных задач, а ее реализацию призваны были обеспечить стратегические приоритеты Программы, ориентированные на ускорение динамики ВРП, диверсификацию экономики региона, повышение регионального имиджа и др.,

Исследуя проблемы, связанные с повышением роли программного инструмента в обеспечении региональной конкурентоспособности, следует отдать приоритет, очевидно, финансовому обеспечению программы. В этом смысле обе комплексные программы развития Республики Адыгея оказались недостаточно результативными, поскольку были профинансированы менее чем на одну четверть от предусмотренных объемов.

Разработчики программ, как правило, концентрируют свои усилия на поиске источников финансирования, прежде всего, внутри региона с дополнительным привлечением средств федерального бюджета. Однако возможности привлечения и использования данных источников финансового обеспечения ограничены в связи с недостаточностью самих средств.

В качестве основы обеспечения саморазвития регионов, реализации их структурной политики, можно наряду с бюджетным финансированием предложить следующие, слабо используемые региональные источники финансовых ресурсов: производственные фонды и площади на промышленных предприятиях, являющиеся на сегодня омертвленным капиталом; земельные участки, непригодные для сельскохозяйственного использования; акции предприятий, находящиеся в собственности государства; свободные средства населения и предприятий региона в региональных финансово-кредитных учреждениях [5].

Эффект от вовлечения в хозяйственный оборот указанных источников в современных условиях возвращения отечественной экономики на траекторию устойчивого развития может оказаться довольно высоким.

Повышению роли программного инструмента в реализации региональной стратегии развития может способствовать создание региональных структур рыночного характера, которые, действуя на основе российского законодательства, призваны оказывать финансовую и организационную поддержку подразделениям, реализующим программу. 


\section{ЛИТЕРАТУРА}

1. Узун, В.Я. Программно-целевой подход к управлению территорией: анализ современного отечественного опыта // Региональная экономика: теория и практика, 2014. № 4 - C. $42-46$.

2. Тамов, А.А. Методологические аспекты формирования системы стратегического управления экономикой муниципального образования / А.А.Тамов, А.В. Науменко // Вестник Адыгейского государственного универс итета. Выпуск 4 (80), 2011 - С. 60-62.

3. Федеральная целевая программа «Социально-экономическое развитие Республики Адыгея на 1997-2000 гг.»/Советская Адыгея, 1997 - 2007. - 17 апреля.

4. Программа экономического и социального развития Республики Адыгея на 20042008 годы // Советская Адыгея, 2004. - 9 марта.

5. Мокрушин, А.А. Стратегические приоритеты развития региональных экономических систем // Вестник Адыгейского государственного университета. Серия 5: Экономика, 2010. № 3 - С. 36-38. 


\title{
ОБОСНОВАНИЕ СТРАТЕГИИ УПРАВЛЕНИЯ КОНКУРЕНТНЫМИ ПРЕИМУЩЕСТВ АМИ РЕГИОНА
}

Алыев Нураддин Али огль Магистрант 2 курса, Адыгейский государственный университет, г. Майкоп Научный руководитель: Тамов А. . д.э.н., профессор Адыгейский государственный университет, г. Майкоп

\begin{abstract}
Аннотация. В статье раскрываются некоторые аспекты, связанные с обоснованием стратегия управления конкурентными преимуществами региона. Исследовательский интерес представляет характеристика роли региональных органов власти в обосновании и реализации конкурентных преимуществ региона.

Ключевые слова: регион, конкурентоспособность, конкурентные позиции, природно-ресурсный потенциал, стратегия.
\end{abstract}

\section{RATIONALE FOR THE STRATEGY OF COMPETITIVE ADVANTAGES OF THE} REGION

\author{
Alyev Nuraddin Ali oglu \\ Undergraduate of 2 courses, Adyghe State University, Maikop \\ Supervisor: Tamov A.A. \\ PhD, professor of Adyghe State University, Maikop
}

\begin{abstract}
The article describes some aspects related to the justification for the control strategy competitive advantages of the region. Research interest is the characterization of the role of regional authorities in a substantiation and realization of competitive advantages of the region. Keywords: region, competitiveness, competitive position, natural resources potential, strategy.
\end{abstract}

Эффективное использование потенциальных конкурентных преимуществ региона предполагает переход к системе стратегического управления. Само по себе его внедрение не является гарантией достижения высокой конкурентоспособности региона, поскольку всегда остается высокая вероятность принятия далеко не самых лучших управленческих решений. Однако в случае, если стратегические решения принимаются обоснованно, возможности этой системы резко возрастают.

Разработка стратегии управления региональными конкурентными преимуществам и предполагает решение следующих проблем:

- исследование ключевых аспектов региональной конкурентоспособности как комплексной проблемы;

- оценка производственных ресурсов региона как источников его конкурентных преимуществ;
- разработка предложений по главным направлениям реализации стратегии повышения региональной конкурентоспособности [1].

Основная цель властей любого российского региона при формировании его конкурентоспособности состоит, главным образом, в создании условий для эффективного использования имеющихся и потенциаль ных факторов производства. При этом основным детерминантом роста благосостояния населения региона является повышение производительности труда. Для этого региональные администрации должны энергично подталкивать местные компании к постоянному повышению качества, внедрению новых ресурсосберегающих технологий, новых, более совершенных методов управления для создания на этой основе долговременного конкурентных преимуществ. 
Роль региональных органов власти в решении указанной задачи состоит, на наш взгляд, в следующем:

- содействие в развитии предприятий и отраслей, в которых концентрируются решающие факторы конкурентного преимущества региона;

- повышение инвестиционной привлекательности в регионе посредством разработки программы стимулирования долгосрочных инвестиций, а также налоговых стимулов для новых компаний, открывающих в регионе свои подразделения;

- создания благоприятных условий для развития малого и среднего предпринимательства;

- создание специализированных факторов производства, включая развитие системы профильного образования и научно-исследовательских центров, а также стимулирование интеграции образования, науки и производства;

- стимулирование процесса притока в регион новых крупных финансовых структур;

- опережающее развитие инфраструктуры;

- внедрение инновационных механизмов управления регионом, ориентированных на создание конкурентных преимуществ, взаимовыгодное сотрудничество многоуровневой системы власти с бизнесом.

Осознание тесной взаимосвязи состояния экономики и ее конкурентоспособности, с одной стороны, и условий для проживания, с другой стороны, позволит вовлечь в реализацию задачи повышения конкурентоспособности взрослое население региона [2].

В дотационных регионах в современных условиях продолжает оставаться:

- довольно напряженная ситуация в области занятости экономически активного населения, особенно в сельской местности;
- значительное отставание от более развитых регионов по реальным денежным доходам в расчете на душу населения;

- несущественной роль зарплаты в формировании доходов населения;

- малодоступной для населения возможность получения качественного образования.

Основные этапы процесса стратегического управления активизацией конкурентных преимуществ региона выглядят следующим образом:

На первом этапе осуществляется формирование концепции развития, которая состоит из следующих разделов:

анализ социально-экономического положения, оценка его преимуществ и недостатков, имеющихся ресурсов, внешних и внутренних факторов;

разработка целей и задач развития региона;

определение стратегических приоритетов и основных направлений социально-эконо м ического развития региона;

формирование необходимых для их реализации механизмов.

На втором этапе происходит формирование комплексной программы социально-эко но м ического развития и программных мероприятий с использованием бизнес-планов.

Третий этап посвящен мониторингу реализации и использованию механизмов обратной связи, позволяющих вносить при необходимости соответствующие корректировки в действующие программы и бизнес-планы.

Одним из ключевых конкурентных преимуществ региона может стать проживающее в нем население. Для того, чтобы это потенциальное преимущество стало реальным, необходимо дать ему на практике возможность участвовать в принимаемых решениях, затрагивающих вопросы социально-эконом ического развития этой территории. Для успешного решения этой проблемы необходимо выстроить механизм коммуникатив но- 
кооперативных структур, учитывающий особенности социокультурной среды региона и обеспечивающий вовлечение общественности, профессиональных сообществ, бизнеса и власти.

Участники разработки региональной стратегии должны понимать, что реализация приоритетов не может быть обеспечена без консолидации усилий, а каждый участник должен внести свой вклад в общий процесс - кадровый, финансовый, инфраструктурный, политический и т.д. При этом следует учитывать, что способы использования ресурсов должны обеспечивать мультипликатив ный эффект, обеспечивая продвижение в нужном направлении и одновременно порождая новые ресурсные возможности.

Процесс стратегического управления включает в себя изучение предшествующих неудач и достижений, смену приоритетов, возможные изменения в организационно управленческой структуре, штатном расписании и практике управления. Все это может создать определенные проблемы для карьеры сотрудников аппарата регионального управления, может порождать напряженность, особенно в сфере трудовых отношений. При этом значение целеустремленности органа регионального управления нельзя переоценить . Этому аспекту управленческой деятельности в специальной литературе уделяется большое внимание [3, 4, 5].

Поскольку на региональном уровне взаимно переплетаются федеральные, региональные и муниципальные интересы, необходимо в процессе стратегического управления обеспечивать динамичное сочетание этих интересов.

В стратегической перспективе позицио нирование проблемных регионов Юга России может привести к превращению их в центры международного значения. Такие потенци- альные возможности предоставляет глобализация, которая требует многоаспектного рассмотрения, учитывая в комплексе и позитивные, и негативные ее последствия.

Отметим, что специализация многих регионов в предшествующие десятилетия формировалась на основе относительных преимуществ местного производства. Другим значимым фактором конкуренции было также расстояние. Предприятия и организации стремились эффективно использовать локальные преимущества, проистекавшие из доступности местного сырья, спроса местных потребителей, а в богатых регионах это давало еще и преимущества большого внутреннего рынка.

В связи с возрастанием значимости глобализация, которая лишает регионы этих традиционных преимуществ, локальные возможности становятся для большинства хозяйствующих субъектов достоянием. Особенно важно для дальнейшего развертывания социальноэкономических процессов то, что к преимуществам дотационных регионов, обусловленных относительно низкой стоимостью труда и природных ресурсов, получают доступ глобальные производители, которые стремятся использовать эти преимущества.

Неуклонное стремление получить доступ к этим преимуществам становится одним из стимулирующих факторов самой глобализации. В этих условиях обеспеченность региона собственными природными или трудовыми ресурсами больше не является важным конкурентным преимуществом с учетом того, что эти ресурсы представлены на глобальных рынках по ценам, сопоставимым с внутрирегиональным и ценами.

Распространенной формой использования ресурсов регионов является также привлечение рабочей силы и определенных категорий населения (молодежи, женщин). Быстро развивающие фирмы в центральных городах все 
более притягивают к себе наиболее качественные трудовые ресурсы из дотационных регионов. Ликвидация барьера расстояния проявляется и в том, что основные экономические позиции регионов, даже самых отдаленных, становятся самым непосредственным образом зависимыми от событий, происходящих в других более развитых регионах.

В условиях глобализации для дотационных регионов Юга России становится жизненно важной проблема удержания конкурентных преимуществ, поскольку от этого зависит сохранение в регионе социально-политической стабильности. У многих из указанных регионов вместе с появляющимися новыми возможностями развития, одновременно возникают и потенциальные угрозы, которые могут значительно снизить потенциальные конкурентные преимущества этих регионов.

Суть положительных конкурентных преимуществ для дотационных регионов Юга России состоит в том, что глобализация спо- собствует вовлечению их в мировые экономические взаимоотношения. Эти регионы могут получить доступ к всемирным рынкам практически на условиях, которые имеют корпорации более развитых стран. Однако на практике многие дотационные регионы не готовы эффективно использовать позитивные результаты и достижения глобализации. Не готовы, в первую очередь, кадры, у которых нет достаточного опыта работы с высокоэффективными технологиями.

Все это обусловливает неравные условия участия в конкуренции для глобальных и остальных фирм, а также для передовых и дотационных регионов. В этих условиях, с одной стороны, дотационным регионам становится все сложнее конкурировать с более развитыми регионами и реальный разрыв в их развитии может со временем нарастать, если федеральный центр не будет предпринимать своевременных мер по сглаживанию усиливающейся дифференциации.

\section{ЛИТЕРАТУРА}

1. Калюжнова, Н. Я. Конкурентоспособность российских регионов в усло виях глобализации - М: ТЕИС, $2004-524$ с.

2. Джаримов, А.А. Регион в едином региональном пространстве. - Ростов-нД, 1996. $434 \mathrm{c}$.

3. Тамов, А.А. Сравнительный анализ региональных среднесрочных программ развития Республики Адыгея как инструмента ее конкурентоспособности / А.А. Тамов, Д.В. Скульчес // Вестник Адыгейского государственного университета. Сер. 5, Экономика. - Майкоп: Изд-во АГУ, 2012. - Вып. 4(97). - С. 48-53.

4. Джаримов, А.А. Конкурентоспособность как характеристика устойчивости региональной экономической системы / А.А. Джаримов, А.А. Мокрушин // Вестник Адыгейского государственного университета. Серия 5: Экономика, 2015 . № 2 (160). - С. 97-103.

5. Мокрушин, А.А. Стратегические приоритеты развития региональных экономических систем // Вестник Адыгейского государственного университета. Серия 5: Экономика, 2010. № 3 - С. $102-104$. 


\title{
СТРАТЕГИЧЕСКИЕ АСПЕКТЫ ФОРМИРОВАНИЯ СУБРЕГИОНАЛЬНЫХ КЛАСТЕРОВ В РЕСПУБЛИКАХ СЕВЕРНОГО КАВКАЗА
}

Берестенева О.В.

Магистрант II курса, Адыгейский государственный университет, г. Майкоп

Научный руководитель: Пиизова А.Р.

кандидат экономических наук, доцент,

Адыгейский государственный университет, г. Майкоп

\begin{abstract}
Аннотация. В статье рассматриваются особенности формирования субрегиональных кластеров в республиках Северного Кавказа как инструмента реализации стратегических приоритетов социально-экономического развития отдельных территорий этих регионов. Ключевые слова: республика, Северный Кавказ, субрегиональный кластер, субрегиональный локалитет, потенциал, стратегия.
\end{abstract}

\section{STRATEG IC ASPECTS OF SUB-REGIONAL CLUSTERS IN THE NORTH CAUCASUS REPUBLICS}

Beresteneva $O . V$. Undergraduate of 2 courses, Adyghe State University, Maikop

Scientific adviser:

Pshizova A.R.

PhD, Associate Professor, Adyghe State University, Maikop

\begin{abstract}
The article discusses the features of the formation of sub-cluster in the North Caucasus as an instrument for the implementation of the strategic priorities of socio-economic development of certain areas of these regions.

Keywords: Republic, North Caucasus, a sub-regional cluster suregionalny locality, potential, strategy.
\end{abstract}

В современных кризисных функционирования российской экономики, в которой бюджетно-обеспеченные регионы играют ключевую роль, сужаются возможности получения остальными регионами ресурсов централизованной поддержки.

В складывающейся ситуации проблемным регионам, в частности республикам Северного Кавказа, предстоит, по существу, заново определить свое место и роль в общеэкономическом пространстве. Для этого они должны пересмотреть систему приоритетов и сконцентрироваться на тех направлениях, где возможно повышение своей конкурентоспособности с использованием различных факторов. Одним из таких факторов выступает стратегическое развитие субрегиональных кластеров.
Субрегиональные кластеры можно представить как муниципальные образования и их группы, сформированные по территориаль но хозяйственному принципу и ориентированные на реализацию однородных или взаимодополняемых функциональных задач.

В условиях глобализации развитие субрегиональных кластеров посредством их превращения в выгодные сферы инвестиций может оказывать существенное влияние на все основные параметры, характеризующие региональную конкурентоспособность.

Значимость субрегиональных кластеров как фактора повышения конкурентоспособности регионов особенно важна для республик Северного Кавказа, в которых ресурсы природно-ресурс ного, географического характера, как их потенциальные конкурентные 
преимущества, локализованы в периферийных субрегиональных территориях. Вовлечение этих конкурентных преимуществ в хозяйственный оборот предполагает разработку стратегии развития субрегиональных кластеров в русле региональной стратегии социально-экономического развития.

Недостаточная теоретико-методологическая и методическая проработанность проблемы стратегического развития субрегиональных кластеров как инструмента повышения конкурентоспособности проблемных регионов Северного Кавказа и отсутствие стратегического начала в деятельности региональных управленческих органов, очевидно, сдерживают вовлечение в оборот этого ресурса развития пространственно-локализованных территорий, ограничивая результативность мер по их развитию.

Другими не менее значимыми причинам и более низкой конкурентоспособности проблемных регионов Северного Кавказа в сравнении с развитыми регионами являются:

- ограниченные ресурсные возможности осуществления структурной политики; низкая инвестиционная привлекательность;

- слабая восприимчивость экономики территорий субрегиональных локалитетов к инновациям;

- неразвитый кадровый потенциал;

- отсутствие достаточной стратегической ориентированности в действиях властных структур по обеспечению однородности социально-экономической среды региона [1].

В указанных условиях для обеспечения конкурентоспособности республик Северного Кавказа особое значение приобретают их потенциальные конкурентные преимущества, обусловленные экономико-географическим положением и природно-ресурсным потенциалом, эффективное использование которых предполагает создание в местах их локализации субрегиональных кластеров.
Обоснование роли субрегиональных кластеров в повышения конкурентоспособности региона сводится к выявлению их функциональных возможностей, способствующих более динамичному и эффективному социально-экономическому развитию образующих их субрегиональных локалитетов. Эти возможности в значительной мере определяются следующими качественными характеристиками.

Особенности субрегиональных кластеров общего характера, способствующие более динамичному и эффективному социально-экономическому развитию отдельных территорий кластера. Ценность субрегиональных кластеров состоит, прежде всего, в том, что они способствуют вовлечению в хозяйственный оборот пространственно локализованных на определенных территориях региона ресурсов, которые сложно или невозможно приобрести на рынке: способность к творчеству, социальный капитал, уникальные знания, уникальные природные объекты, экономико-географическое положение региона, имидж региона и др.

Потенциал субрегионального кластера, как подсистемы региональной социально-экономической системы, развитие которой базируется на формировании, распределении и использовании пространственно локализованных ресурсов, выше, чем совокупный потенциал каждого из образующих его хозяйствующих субъектов. Управление экономикой субрегионального кластера нацелено на комплексное социально-экономическое развитие субрегиональной территории в целом и каждого из расположенных на ней муниципального образования.

Рост за последние годы интереса со стороны крупных иностранных и отечественных инвесторов к природно-ресурсному потенциалу Республики Адыгея обусловили начало реального смещения приоритетов в развитии 
экономики региона в сторону активизации освоения ее туристско-рекреационных, аграрно-продовольственных и прочих ресурсов, что привело к заметному повышению роли соответствующих субрегиональных локалитетов в формировании ключевых конкурентозначимых параметров развития региона и, соответственно, - в расширении возможностей создания на указанных территориях субрегиональных кластеров.

Возможности создания в Республике Адыгея субрегиональных кластеров в целях обеспечения конкурентоспособности региона сдерживаются нерешенностью следующих проблем:

- обеспечение необходимых масштабов деятельности (критического объема производства);

- дефицитность коммерческих и инфраструктурных услуг;

- недостаток подходящих помещений для размещения предприятий;

- острая нехватка капитала для предпринимательской деятельности;

- преобладание в экономике муниципальных образований аграрной и (или) одной отрасли промышленности;

- узкая сфера трудовых навыков;

- низкая культура предпринимательства;

- ограниченность финансовой поддержки со стороны муниципальной власти;

- сопротивление развитию нового бизнеса со стороны существующих предприятий;

- ограниченность источников и низкое качество информации для бизнеса;

- психологическая неготовность местного населения к росту предпринимательства и др.

Несмотря на то, что говорить о создании эффективного института управления экономикой субрегиональных локалитетов в лице субрегиональных кластеров на данном этапе развития российской экономики преждевре- менно, обоснование и систематизация инструментальных средств, позволяющих стратегически ориентировать процесс ускоренного их формирования и сбалансированного развития на основе активизации межмуниципальных интеграционных процессов, является насущной управленческой задачей.

Учитывая сложность, многоуровневость и многоаспектность процессов функцио ниров ания субрегиональных кластеров, как сложного социально-экономического формирования, необходимо в основу методологии конструирования механизмов управления ими заложить системный подход, позволяющий расчленить эту конструкцию на ряд взаимосвязанных подсистем: организационный, экономический, финансово-бюджетный, правовой, социальный, мотивационный и другие механизмы.

При этом процесс стратегического управления субрегиональным кластером представляет собой практически непрекращающи йся динамичный процесс комплексного решения актуальных проблем, выдвигаемых практикой социально-экономического функцио нирования в условиях растущей неопределенности внешней среды и ужесточения ресурсной ограниченности. Указанные явления обусловливают необходимость разработки и реализации стратегии развития субрегионального кластера в рамках системы стратегического управления социально-экономическим развитием региона.

В современных условиях одним из ключевых требований к механизму реализации стратегических приоритетов развития субрегионального кластера должно быть определение состава инструментов и последовательности их применения таким образом, что обеспечить эффективное вовлечение в хозяйственный оборот его потенциальных конкурентных преимуществ и как результат - повышение конкурентоспособности охваченной 
кластером территории и региона в целом. К совокупности таких инструментов отнесены:

- повышение инвестиционной привлекательности субрегионального кластера;

- эффективное использование возможностей среднесрочной программы развития субрегионального кластера;

- формирование конструктивного взаимодействия муниципальных органов управления с бизнесом и населением территории [3, 4].

Системное использование предложенных инструментов обеспечивает эффективное вовлечение в хозяйственный оборот потенциальных конкурентных преимуществ входящих в состав кластера хозяйствующих субъектов и территорий.

Стратегическое управление развитием субрегиональных кластеров предполагает решение комплекса задач, взаимоувязанных по времени, ресурсам и некоторым другим параметрам и реализуемых в долгосрочной перспективе. При этом неизбежно возникает проблема согласования долгосрочных решений и текущих задач. В качестве инструмента разрешения указанного противоречия особая роль принадлежит среднесрочной целевой программе развития субрегионального кластера, являющейся в современных условиях наиболее эффективным инструментом механизма реализации его стратегических приоритетов.

Наблюдаемое в последнее время формирование в Республике Адыгея зон активизации тонуса хозяйственной деятельности («точек роста») создает благоприятные предпосылки для развертывания в них субрегиональных кластеров:

- агропромышленного типа (в субрегионе, охватывающем территории Гиагинского, Кошехабльского, Красногвардейского и Шовгеновского районов);

- туристско-рекреационного типа (в субрегионе, представленном территорией Майкопского района);

- транспортно-логистического типа (в субрегионе, включающем территории г. Адыгейска, Тахтамукайского и Теучежского районов) [2].

Возможность использования кластерного инструмента для опережающего развития периферийных муниципальных образований Республики Адыгея обусловлена значительной степенью соответствия выделенных субрегионов признакам, требуемым для создания и последующего развития территориальнохозяйственных кластеров.

\section{ЛИТЕРАТУРА}

1. Апишев, А.А. Методологические аспекты обоснования стратегических приоритетов развития АПК проблемного региона в посткризисных условиях / А.А. Апишев, А.А. Тамов // Вестник Адыгейского государственного университета. Cep. 5, Экономика. - Майкоп: Изд-во АГУ, 2012. Вып. 1(91). - С. 55-59.

2. Тамов, А.А. Роль АПК в реализации региональных интересов / А.А. Тамов, М.К. Тамова // Вестник Адыгейского государственного университета. Сер. 5, Экономика. - Майкоп: Изд-во АГУ, 2014. Вып. 2(141). - С. 55-60.

3. Мокрушин, А.А. Потенциал кластерных структур в развитии взаимодействия вертикально интегрированных корпораций с региональными экономическими системами Юга России // Вестник Адыгейского государственного университета. Серия 5: Экономика, 2014. № 3(150). - С. 152-161.

4. Мокрушин, А.А. Стратегические приоритеты развития региональных экономических систем // Вестник Адыгейского государственного университета. Серия 5: Экономика, 2010. № 3. - С. 60-65. 


\title{
ЗАРУБЕЖНЫЙ ОПЫТ РАЗВИТИЯ ГОСУДАРСТВЕННО-ЧАСТНОГО ПАРТНЕРСТВА
}

Картамышев В.В. аспирант, Адыгейский государственный университет, г. Майкоп

Тхакушинова С.A. Адыгейский государственный университет, г. Майкоп Научный руководитель: Мокрушин А.A. д.э.н., профессор, Адыгейский государственный университет, г. Майкоп

Аннотация: В данной статье рассматривается зарубежный опыт реализации проектов государственно-частного партнерства (ГЧП). Раскрывается сущность форм ГЧП и сферы его применения, характерные черты, присущие данному виду партнерства. Также представлен рейтинг ГЧП в сферах экономики.

Ключевые слова: ГЧП, проекты, регионы, финансовые ресурсы, бизнес, государство.

\section{FOREIGN EXPERIENCE OF DEVELOPMENT OF PUBLIC-PRIVATE PARTNERSHIP}

Kartamishev $V . V$. Post-Graduate Student, Adyghe State University, Maikop,

Tkhakushinova S.A. Adyghe State University, Maikop Supervisor: Mokrushin A.A. PhD, Full Professor, Adyghe State University, Maikop

\begin{abstract}
This article examines the public-private partnership (PPP) as an effective toolfor the implementation of socially significant projects. The essence of the forms of PPP and its scope. Also consider the dynamics of industry projects.

Keywords: PPP, transport infrastructure, municipal infrastructure, social infrastructure, energy infrastructure, projects, regions, financial resources, business and the state.
\end{abstract}

Public-private partnership в переводе на русский «государственно-частное партнерство», распространенная форма партнерства между государством и бизнесом. В зарубежной литературе также используется термин «частногосударственное партнерство», с целью подчеркнуть приоритетную роль частного сектора.

Партнёрство между бизнесом и государством создается при сохранении в государственной собственности важнейших нацио- нальных объектов, часть прав при этом делегируются собственнику частного сектора. А это значит, что в традиционно государственную сферу экономики привносятся своего рода частные товары и услуги (private goods), что дает возможность создавать условия для оптимального управления, эффективного функционирования и рационального использования ресурсов.

В разных странах существуют свои трактовки государственно-частного партнёрства (рисунок 1). 


\begin{tabular}{|c|c|}
\hline Страна & Определение \\
\hline США & $\begin{array}{l}\text { Закрепленное в договорной форме соглашение } \\
\text { между государством и частной компанией, } \\
\text { позволяющее последней определенным образом } \\
\text { участвовать в государственной собственности в } \\
\text { большей степени по сравнению с } \\
\text { существующей практикй. }\end{array}$ \\
\hline Страны EC & $\begin{array}{l}\text { Форма кооперации между общественными } \\
\text { властями и бизнесом, целями которой являются } \\
\text { обеспечение финансирования, строительства, } \\
\text { модернизации, управления, эксплуатации } \\
\text { инфраструктуры или оказания услуг. }\end{array}$ \\
\hline Великобритания & $\begin{array}{l}\text { Ключевой элемент стратегии правительства по } \\
\text { обеспечению современного } \\
\text { высококачественного обслуживания и } \\
\text { повышения конкурентоспособности страны, } \\
\text { имеющий широкий диапазон бизнес-структур и } \\
\text { форм товарищества: от частной инициативы и } \\
\text { продажи части акций в принадлежащих } \\
\text { государству предприятий, осуществляющих } \\
\text { коммерческую деятельность. }\end{array}$ \\
\hline Ирландия & $\begin{array}{l}\text { Сотрудничество государственного частного } \\
\text { сектора в целях реализации конкретного } \\
\text { проекта или оказание населению услуг } \\
\text { социального характера, обязанность } \\
\text { предоставления которых возлагается на } \\
\text { государственный сектор }\end{array}$ \\
\hline
\end{tabular}

Рисунок 1 - Различные трактовки ГЧП в зарубежных странах 
Сущность ГЧП в международных документах раскрывается как «форма партнерства между органами государственной власти и бизнесом, чьей главной целью является обеспечение финансирования, реконструкция, сооружение, управление и содержание объекта инфраструктуры или предоставления услуги» [1]. ГЧП может определяться как «партнерство между государственным и частным секторами с целью осуществления проекта или оказания услуги, которые традицио нно предоставляются государственным сектором [3].

Государственно-частное партнерство рассматривается как определенный формат взаимодействия государства и бизнеса, включаю- щий различные формы долгосрочных контрактов, которые заключены между юридическими лицами и государственными органами с целью обеспечения финансирования, исполнения, планирования и эксплуатации объектов, производств и предоставления услуг государственного сектора [4]. Государство рассматривается как «обобщающий субъект общественной власти, который включает все уровни управления - федеральный региональный и муниципальный, и который реализует властные полномочия [5].

Характерные черты, присущие государственно-частному партнерству в разных зарубежных странах, схематично представлены на рис. 2.

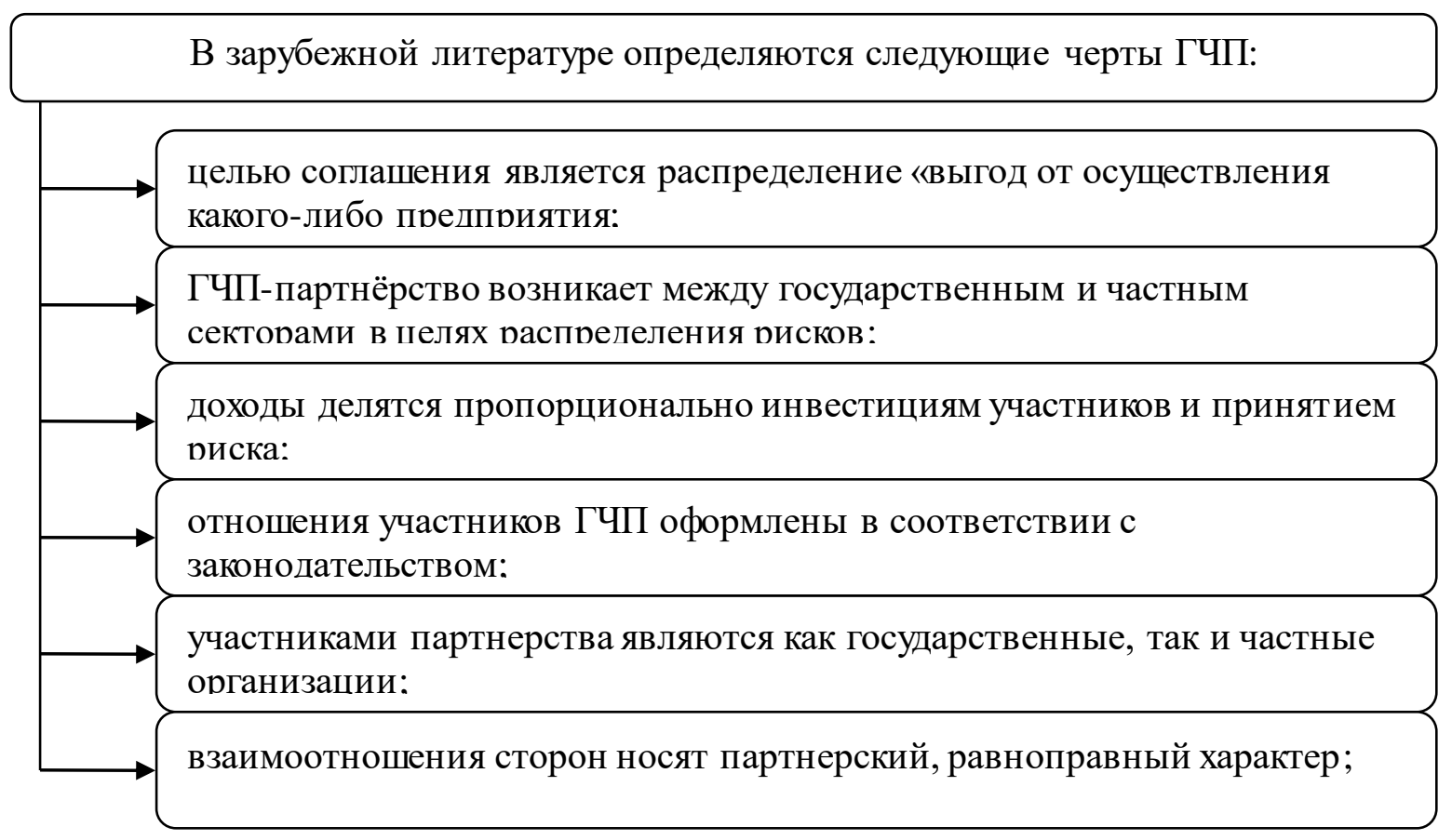

Рисунок 2 - Характерные черты, присущие ГЧП (согласно зарубежсным источникам)

В качестве лидеров в области государственно-частного партнерства можно назвать такие страны как Бразилия, Индия, Аргентина, Таиланд, Турция, Мексика, Великобритания, США, Франция и Германия. При этом в США, кооперации властей и частников особенно широко распространяется на муниципальном уровне государственной иерархии.
В Бразилии принятие следующих законодательных актов: Национальная программа по приватизации (National Privatization Program) и Закон о конщессиях (№ 8987/95) способствовало распространению механизмов ГЧП. Благодаря этим документам была заложена основа участия частного сектора в бразильской экономике. В Бразилии нормативно-правовая база выстроена на основе 
принципа предоставления услуг государством в развитии инфраструктуры только в том случае, если есть необходимость, и нет других альтернатив, что соответствует фундаментальным изменениям, которые вносятся в государственную политику. Уже в 1995 г. в Бразилии приняли ключевые норматив ноправовые акты, однако положение по ГЧП было закреплено позже в Законе о государственно-частном партнёрстве № 11079 от
2004 г., который и дополнил закон о концессиях. ГЧП в Бразилии можно определить как концессионный договор, но фактически он является формой концессии ВОТ (Build Operate - Transfer), предназначе нной для проектов, которые нуждаются в дополнитель но й поддержке государства. Сфера энергетики ЖКХ является наиболее популярной сферой в Бразилии, в которой реализуются проекты ГЧП.

Отношение частных инвестиций в проектах ГЧП к номинальному ВВП

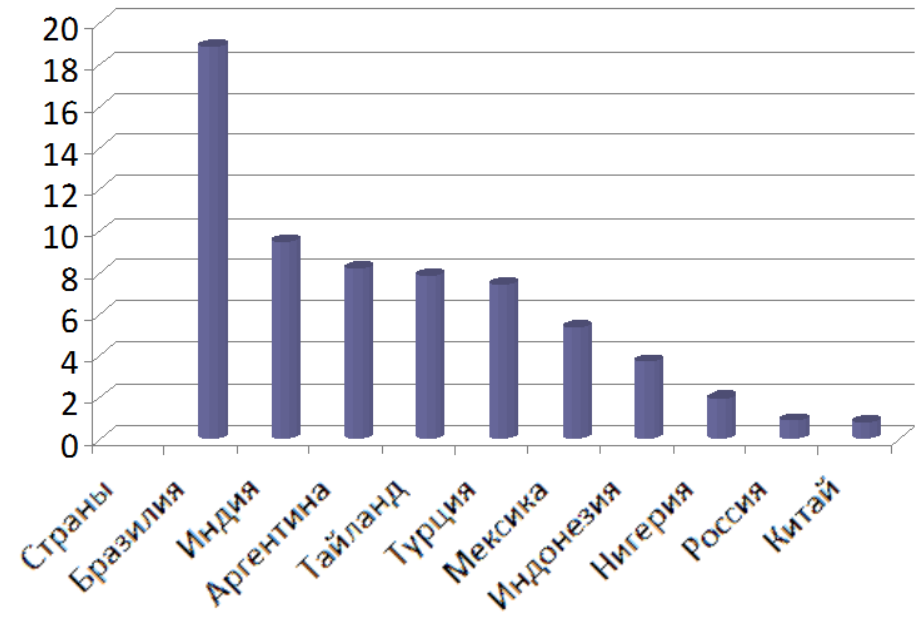

Рисунок 3 - Отночение частных инвестиций в проектах ГЧП к номинальному ВВП

Азиатский рынок ГЧП - это один из наиболее динамично развивающихся рынков государственно-частного партнерства. Азиатские страны имеют меньше финансовых возможностей по реализации проектов в социальной сфере и в модернизации инфраструктуры, но количество проектов, которые здесь реализуются, с каждым годом растет.

Ведущими странами по количеству проектов, которые заключались в последние годы, являются страны, которые характеризую тся значительным ростом ВВП: Индия, Китай, Тайланд, Япония. В Индии множество положительных примеров организации государственно-частных партнерств с применением различных механизмов их поддержки. Лидерами в структуре проектов в Индии является электроэнергетика и дорожное строительство. Количество проектов в инфраструктурной сфере за последние двадцать лет в Индии перевалило за 600, с общим объемом капиталовложений в 273 млрд долл.

Среди показательных проектов в Индии можно выделить такие как:

1) строительство в стране первого частного водопровода в Тирупуре (шт. Тамилнаду). Средства затраченные правительством штата составили всего около 12,5 млн долл., 217,5 млн долл. были внесены частным инвестором. Данный проект реализовывался путем создания проектной компании, уставный 
капитал которой был сформирован правительством штата Тамилнаду и компанией IL\&FS;

2) расширение и реконструкция дороги восточного побережья, в котором затраты частной компании в 12 раз превысили вложения правительства штата Тамилнаду;

3) строительство двухпричального морского контейнерного терминала Nhava Sheva. Проект был реализован совместно компание й P\&O Australia и Jawaharlal Nehru Port 'Crust.

В Аргентине была реализована одна из крупнейших концессий в сфере водоснабжения во всем мире. Действие проекта распространяется на территории города, в котором проживают около 12 млн. жителей. При принятии решения администрацией города о необходимости привлечения частных инвестиций в форме конщессии система водоснабжения и канализации Буэнос-Айреса характеризовалась износом оборудования, низким доступом к услугам и постоянно растущим и тарифами на услуги. Около 80\% труб нуждались в срочной замене. В Буэнос-Айресе только лишь 70\% населения имело доступ к услугам центрального водоснабжения и лишь 58\% к услугам канализации, а в пригороде эти показатели составляли «соответственно 55\% и $36 \%$.

Некоторые результаты проекта:

- увеличение инвестиций в сфере водоснабжения примерно в 10 раз;

- рост производства питьевой воды на 39\%;

- уменьшение тарифов;

- процент оплаты счетов возрос до 90\%.

- расширение сетей водоснабжения и канализации на 28\% и $19 \%$ соответственно;

- расширение систем водоснабжения и канализации на 27\% и 19\% соответственно, что позволило 2 млн. жителей получить доступ к водоснабжению и 1 млн. жителей к канализации.
Плюсом для бизнеса была возможность получения прибыли уже после первых 5 лет инвестиций от незначительного роста тарифов.

В США в настоящее время для реализации проектов государственно-частного партнерства существует институциональная основа, которая позволяет бизнесу принимать участие в ранее недоступных для него сферах экономики, иметь долгосрочную возможность реализовывать продукцию и загруженные мощности а государству в условиях недостатка бюджетных средств привлекать альтернативные источники финансирования.

Что касается Франции, она обладает богатыми традициями государственно-частного партнерства, которые включают в себя деятельность сообществ смешанной экономики (SEM) и предоставление конщессий. Местные органы власти и государственный сектор в соответствии с законодательством должны иметь большую долю в составе активов SEM и следовательно они играют главенствующую роль в управлении ими. SEM осуществляют свою деятельность на основе заключаемого местными властями соответствующего договора.

Соединенное Королевство Великобритания является государством, в котором механизм ГЧП был внедрен в национальную правовую систему уже в 1992 году. Уникальность опыта государственно-частного партнерства состоит в отсутствии соответствующего законодательства каким-либо образом ограничивающая сферу применения ГЧП. Согласно практике реализации ГЧП их следует рассматривать как гражданско-правовой договор. Основными признаками, которого являются:

1) государственная собственность или любые другие формы совместной деятельности государства и частного сектора как предмет взаимодействия;

2) распределение рисков и расходов; 
3) распределение прав и обязанностей государства и частного сектора;

Зарубежный опыт вместе с отечественной практикой показывают, что государственно - частное партнерство способно содействовать реализации программ социально-экономической модернизации с наименьшими потерями и издержками для общественного сектора.

\section{ЛИТЕРАТУРА}

1. Варнавский, В.Г. Партнерство государства и частного сектора: формы, проекты, риски. - М.: Наука, 2005 г. - С. 28.

2. Гафурова, Г.Т. Опыт Индии в поддержке и развитии государственно-частного партнерства // Актуальные проблемы экономики и права, 2013 . №3 (27). [Электронный pecypc]. - Режим доступа: http://cyberleninka.ru/article/n/opyt-indii-v-podderzhke-irazvitii-gosudarstvenno-chastnogo-partnerstva.

3. Рейтинг регионов ГЧП-2016. Развитие государственно-частного партнерства в субъектах Российской Федерации. - М.: Центр развития государственно-частного партнерства, 2016.

4. Smirnov, A. Artificial intelligence: Concepts and Applicable Uses. Lambert Academic Publishing, 2013 - P 105.

5. Smirnov, A. The potential effectiveness of the detection of pulsed signals in the nonuniform sampling. / A. Smirnov, A. Abraham, S. Vorobiev // - IEEE, 2013 - P. 120-121.

6. Zakharova, E.N. Forms and Mechanisms of Public-Private Partnerships in Innovative Modernization of the Western Europe Economies / E.N. Zakharova, A.A. Mokrushin, A.R. Pshizova, S.A. Khatukay, S.K. Chinazirova. // Asian Social Science, 2015. T. 11. № 21. - C. 321-330.

7. Керашев, А.А. Потенциал государственно-частного партнерства в развитии взаимодействия вертикально-интегрированных корпораций с региональными экономическими системами России / А.А. Керашев, А.А. Мокрушин // Вестник Адыгейского государственного университета. Серия 5: Экономика, 2014. № 2(141). - С. 48-57. 


\title{
ОЦЕНКА РЕЗУЛЬТАТОВ ДЕЯТЕЛЬНОСТИ СУБЪЕКТОВ МАЛОГО И СРЕДНЕГО ПРЕДПРИНИМАТЕЛЬСТВА В РЕСПУБЛИКЕ АДЫГЕЯ
}

Картамышев В.В. аспирант, Адыгейский государственный университет, г. Майкоп

Тхакушинова С.A.

Адыгейский государственный университет, г. Майкоп

Научный руководитель: Мокрушин А.A.

д.э.н., профессор, Адыгейский государственный университет, г. Майкоп

\begin{abstract}
Аннотация: В данной статье рассмотрень основнье результаты деятельности субъектов малого и среднего предпринимательства Республики Адыгея. Проведен анализ динамики изменения выручки субъектов малого предпринимательства в разрезе районов Республики Адыгея, видов хозяйственной деятельности. Представлень результаты анализа динамики оборота мальх предприятий по районам Республики Адыгея.

Ключевые слова: малый бизнес, средний бизнес, Республика Адыгея, инвестиционная активность, инвестиции.
\end{abstract}

\section{EVALUATING THE RESULTS OF SMALL AND MEDIUM ENTREPRENEURSHIP IN THE REPUBLIC ADYGEA}

Tkhakushinova S.A. Adyghe State University, Maikop Supervisor: Mokrushin A.A. PhD, Professor, Adyghe State University, Maikop

\begin{abstract}
This article describes the main results of the activities of small and medium-sized enterprises of the Republic of Adygea. The article presents the analysis of trends in the revenues of small businesses in terms of regions of the Republic of Adygea, types of economic activity. The results of the analysis of the dynamics of the turnover of small enterprises of regions of the Republic of Adygea are presented.
\end{abstract}

Keywords: small business, medium business, the Republic of Adygea, investment activity, investment

Малое предпринимательство играет очень важную роль в экономике любой страны. Развитие данного сектора предпринимательской деятельности способствует позитивному воздействию на социально-экономическое положение как отдельно взятых регионов, так и стран в целом.

Сфера малого и среднего бизнеса Республики Адыгея включает в себя 5,2 тысячи малых и средних предприятий и 15,3 тысячи индивидуальных предпринимателей, где трудится 45 тысяч человек. Развитие малого и среднего предпринимательства является приоритетным направлением территориаль но й экономической политики, осуществляемой государством, которая направлена на создание конкурентных преимуществ территорий. В соответствии с долгосрочной стратегией социально-экономического развития России до 2020 г. планируется увеличение доли малого и среднего бизнеса в ВВП страны к 2020 г. до 60-70\% [2].

Аналитическим центром ОАО «МСП Банк» в 2015 году был составлен рейтинг «Индекс качества условий для малого и среднего бизнеса в 2013-2014 гг. Региональные диспропорции». Республика Адыгея в данном рейтинге входит в группу «В» (группа «дого- 
няющих» регионов), характеризующуюся показателями интегрального индекса выше средних по стране.

Малое и среднее предпринимательство внесло весомый вклад в экономику региона это третья часть валового регионального продукта республики, всех занятых в экономике, 47 \% налоговых поступлений, более $45 \%$ общего оборота организаций по республике. Только за 2015 год поступило более 4 млрд. руб. налогов от субъектов малого и среднего предпринимательства, что превышает уровень 2014 года в 1,3 раза. Также в 2015 году по сравнению с предыдущим возросла доля налоговых поступлений от субъектов малого и среднего предпринимательства на 6,2\% [3].

Аналитиками агентства деловой информации Top-RF.ru в 2015 г. был составлен рейтинг регионов России по предпринимательской активности, который рассчитывается по доле индивидуальных предпринимателей в экономически активном населении региона. По результатам данного рейтинга Республика Адыгея занимает второе место (8,21\%) после Краснодарского края (8,78\%) [4].

Число субъектов малого бизнеса (юридических лищ), не являющихся микро-предприя тиями в 2014 году составило 457 единиц, что на 2,0\% больше, чем в 2012 году. Из-за небольших размеров бизнеса малые предприятия острее реагируют как на глобальные так и на региональные экономические процессы: быстрее приостанавливают производство или закрываются при неблагоприятной конъюнктуре рынка, меняют профиль деятельности, а также территориальное размещение. Наиболее подвержены территориальной миграции малые предприятия Тахтамукайского и Теучежского районов и г. Адыгейска из-за близости к г. Краснодару.

Таблица 1 - Число малых предприятий и их распределение по районам Республики Адыгея

\begin{tabular}{|l|c|c|c|c|c|c|c|c|}
\hline & \multicolumn{2}{|c|}{2012} & \multicolumn{2}{c|}{2013} & \multicolumn{2}{c|}{2014} & \multicolumn{2}{c|}{$\begin{array}{c}\text { Прирост(+), } \\
\text { снижение(-) } \\
\text { единиц }\end{array}$} \\
\cline { 2 - 11 } & единиц & $\begin{array}{c}\text { в \% к } \\
\text { итогу }\end{array}$ & единиц & $\begin{array}{r}\text { в \% к } \\
\text { итогу }\end{array}$ & единиц & $\begin{array}{c}\text { в \% к } \\
\text { итогу }\end{array}$ & за 2013 & за 2014 \\
\hline Всего & 448 & 100,0 & 428 & 100,0 & 457 & 100,0 & -20 & 29 \\
\hline в том числе: & & & & & & & & \\
\hline г. Майкоп & 219 & 48,9 & 208 & 48,6 & 234 & 51,2 & -11 & 26 \\
\hline г. Адыгейск & 14 & 3,1 & 16 & 3,7 & 15 & 3,3 & 2 & -1 \\
\hline районы: & & & & & & & & -1 \\
\hline Гиагинский & 22 & 4,9 & 21 & 4,9 & 20 & 4,4 & -1 & -1 \\
\hline Кошехабльский & 11 & 2,5 & 11 & 2,6 & 10 & 2,2 & 0 & -1 \\
\hline Красногвардейский & 20 & 4,5 & 21 & 4,9 & 19 & 4,1 & 1 & -2 \\
\hline Майкопский & 43 & 9,6 & 36 & 8,4 & 38 & 8,3 & -7 & 2 \\
\hline Тахтамукайский & 91 & 20,3 & 88 & 20,6 & 94 & 20,6 & -3 & 6 \\
\hline Теучежский & 18 & 4,0 & 17 & 4,0 & 17 & 3,7 & -1 & 0 \\
\hline Шовгеновский & 10 & 2,2 & 10 & 2,3 & 10 & 2,2 & 0 & 0 \\
\hline
\end{tabular}

Как видно из таблицы 1 распределение малых предприятий по районам Республики Адыгея неравномерно. Больше половины (в 2014 году - 51,2\%) от общего числа малых предприятий сосредоточено в г. Майкопе, по сравнению с 2012 годом наблюдается тенденция к увеличению (на 2,3\%). В Тахтамукай- 
ском районе, характеризующемся наибольшей инвестиционной привлекательностью, отмечается незначительное увеличение доли малых предприятий за 2012-2014 годы (на $0,3 \%)$.

Наименьшим уровнем развития характеризуется малое предпринимательство в Кошехабльском и Шовгеновском районах республики (на их долю в сумме приходится менее 5\% малых предприятий Адыгеи). В 2012-2014 годах число малых предприятий в Шовгеновском районе не менялось и стабильно составляет 10 единиц. Наибольшее снижение числа малых предприятий в Республике Адыгея в 2012-2014 годах сложилось в Майкопском (на
$11,6 \%)$ и Гиагинском (на 9,1\%) районах. В Кошехабльском, Теучежском и Красногвардейском районах число малых предприятий сократилось на одну единицу. Причинами снижения числа малых предприятий явились ликвидация, банкротство, изменение типа на «микропредприятие», а также миграция на территорию соседних регионов.

В 2014 году сумма выручки от продаж продукции, товаров, работ, услуг (без НДС, акцизов и иных аналогичных платежей), полученной малыми предприятиями, составила 26231,3 млн. рублей, что на 4,2\% больше выручки 2012 года (с учетом инфляции - меньше на $12,6 \%)$.

\section{Таблица 2 - Выручка малых предприятий по видам экономической деятельности}

\begin{tabular}{|c|c|c|c|c|c|c|}
\hline & \multicolumn{2}{|l|}{2012} & \multicolumn{2}{|l|}{2013} & \multicolumn{2}{|l|}{2014} \\
\hline & $\begin{array}{l}\text { млн. } \\
\text { рублей }\end{array}$ & $\begin{array}{l}\text { В \% к } \\
\text { итогу }\end{array}$ & $\begin{array}{l}\text { млн. } \\
\text { рублей }\end{array}$ & $\begin{array}{l}\text { В } \% \text { к } \\
\text { итогу }\end{array}$ & $\begin{array}{l}\text { млн. } \\
\text { рублей }\end{array}$ & $\begin{array}{l}\text { в \% к } \\
\text { итогу }\end{array}$ \\
\hline Всего & 25186,0 & 100,0 & 21662,5 & 100,0 & 26231,3 & 100,0 \\
\hline $\begin{array}{l}\text { Сельское хозяйство, охота и лесное хозяй- } \\
\text { ство }\end{array}$ & 1200,1 & 4,8 & 1249,3 & $\overline{5,8}$ & 1137,6 & 4,3 \\
\hline Рыболовство, рыбоводство & - & - & - & - & 6,5 & 0,0 \\
\hline Добыча полезных ископаемых & 1024,1 & 4,1 & 246,5 & 1,1 & 206,5 & 0,8 \\
\hline Обрабатывающие производства & 5446,3 & 21,6 & 4488,8 & 20,7 & 4917,9 & 18,8 \\
\hline $\begin{array}{l}\text { Производство и распределение электроэнен } \\
\text { гии, газа и воды }\end{array}$ & 192,2 & $\overline{0,8}$ & 200,0 & 0,9 & 250,1 & 1,0 \\
\hline Строительство & 4405,8 & 17,5 & 3507,5 & 16,2 & 4097,0 & 15,6 \\
\hline $\begin{array}{l}\text { Оптовая и розничная торговля; ремонт ав- } \\
\text { тотранспортных средств, мотоциклов, бы- } \\
\text { товых изделий и предметов личного поль- } \\
\text { зования }\end{array}$ & 9551,8 & 37,9 & 9593,6 & 44,3 & 12461,7 & 47,5 \\
\hline Гостиницы и рестораны & 316,7 & 1,3 & 357,5 & 1,6 & 367,6 & 1,4 \\
\hline Транспорт и связь & 1739,6 & 6,9 & 555,2 & 2,6 & 879,4 & 3,4 \\
\hline $\begin{array}{l}\text { Операции с недвижимым имуществом, } \\
\text { аренда и предоставление услуг }\end{array}$ & 1008,2 & $\overline{4,0}$ & 1162,0 & 5,4 & 1402,4 & 5,3 \\
\hline Образование & 6,5 & $\overline{0,0}$ & 5,2 & $\overline{0,0}$ & 3,4 & 0,0 \\
\hline $\begin{array}{l}\text { Здравоохранение и предоставление соци- } \\
\text { альных услуг }\end{array}$ & 29,0 & 0,1 & 35,3 & 0,2 & 138,2 & 0,5 \\
\hline $\begin{array}{l}\text { Предоставление прочих коммунальных, } \\
\text { социальных и персональных услуг }\end{array}$ & 265,7 & 1,0 & 261,6 & 1,2 & 363,0 & 1,4 \\
\hline
\end{tabular}


За исследуемый период удельный вес выручки торговых предприятий стабильно составляет в среднем около $43 \%$ общей суммы выручки, но имеет тенденцию к увеличению (за 2012-2014гг - на 9,6 процентного пункта). Доля выручки предприятий, занятых в обрабатывающих производствах и строительстве, сократилась на 2,8 процентного пункта и 1,9 процентного пункта соответственно (в среднем за период составляла $20 \%$ и $16 \%$ ).

Более $71 \%$ объема выручки приходится на малые предприятия г. Майкопа и Тахтамукайского района (рост за 2012-2014 гг. на 1,9 процентного пункта).

Таблица 3 -Выручка малых предприятий по районам Республики Адыгея

\begin{tabular}{|c|c|c|c|c|c|c|c|c|}
\hline & \multicolumn{2}{|c|}{2012} & \multicolumn{2}{|c|}{2013} & \multicolumn{2}{|c|}{2014} & \multirow{2}{*}{$\begin{array}{l}2014 \\
6 \% \kappa \\
2013\end{array}$} & \multirow{2}{*}{$\begin{array}{l}2013 \\
\text { в \% к } \\
2012\end{array}$} \\
\hline & $\begin{array}{c}\text { млн. } \\
\text { рублей }\end{array}$ & $\begin{array}{l}\text { в\% } \% \\
\text { итогу }\end{array}$ & $\begin{array}{c}\text { млн. } \\
\text { рублей }\end{array}$ & $\begin{array}{l}\text { в\% } \% \\
\text { итогу }\end{array}$ & $\begin{array}{c}\text { млн. } \\
\text { рублей }\end{array}$ & $\begin{array}{l}\text { в\% } \% \\
\text { итогу }\end{array}$ & & \\
\hline Всего & 25186,0 & 100,0 & 21662,5 & 100,0 & 26231,3 & 100,0 & 121,1 & 86,0 \\
\hline в том числе: & & & & & & & & \\
\hline г. Майкоп & 10033,6 & 39,8 & 8229,8 & 38,0 & 11458,3 & 43,7 & 139,2 & 82,0 \\
\hline г. Адыгейск & 491,6 & 2,0 & 719,0 & 3,3 & 1144,3 & 4,4 & 159,2 & 146,3 \\
\hline районы: & & & & & & & & \\
\hline Гиагинский & 2345,7 & 9,3 & 1787,7 & 8,3 & 2121,6 & 8,1 & 118,7 & 76,2 \\
\hline Кошехабльский & 1315,9 & 5,2 & 808,0 & 3,7 & 337,8 & 1,3 & 41,8 & 61,4 \\
\hline Красногвардейский & 561,6 & 2,2 & 808,0 & 3,7 & 585,8 & 2,2 & 72,5 & 143,9 \\
\hline Майкопский & 1502,7 & 6,0 & 1706,6 & 7,9 & 1884,9 & 7,2 & 110,4 & 113,6 \\
\hline Тахтамукайский & 7510,7 & 29,8 & 5638,0 & 26,0 & 7301,2 & 27,8 & 129,5 & 75,1 \\
\hline Теучежский & 976,9 & 3,9 & 1312,2 & 6,1 & 1109,2 & 4,2 & 84,5 & 134,3 \\
\hline Шовгеновский & 447,3 & 1,8 & 653,2 & 3,0 & 288,2 & 1,1 & 44,1 & 146,0 \\
\hline
\end{tabular}

По сравнению с предыдущим периодом, наиболее значительно возросла за 2014 год выручка, полученная в г. Адыгейске (на 47,8 процентного пункта выше уровня инфляции), г. Майкопе (на 27,8 процентного пункта выше уровня инфляции), а в Шовгеновском районе выручка сократилась в 2,3 раза, за счет введения на ряде предприятий процедуры банкротства или смены юридического адреса [5].

Выручка в расчете на одно малое предприятие в 2012-2014гг. увеличилась на 2,1\% и составила 57,4 млн. рублей (в 2012 году - 56,2 млн. рублей; в 2013 году - 50,6 млн. рублей). Выше среднереспубликанского уровня выручка в расчете на одно предприятие в 2014 году была в Гиагинском (106,1 млн. рублей) и
Тахтамукайском (77,7 млн. рублей) районах, г. Адыгейске (76,3 млн. рублей) и Теучежском районе (65,2 млн. рублей).

Важнейшим экономическим показателем производственно-хозя йственной деятельности предприятия является его оборот, который включает в себя показатели «Отгружено товаров собственного производства, выполнено работ и услуг собственными силами» (в 2014 году 54,4\%, в 2013 году - 54,5\%) и «Продано товаров несобственного производства» (45,6\% и 45,5\% соответственно). Оборот малых предприятий в 2014 году по сравнению с 2012 годом увеличился незначительно (на $4,2 \%$ ) и составил 26262,1 млн. рублей. 


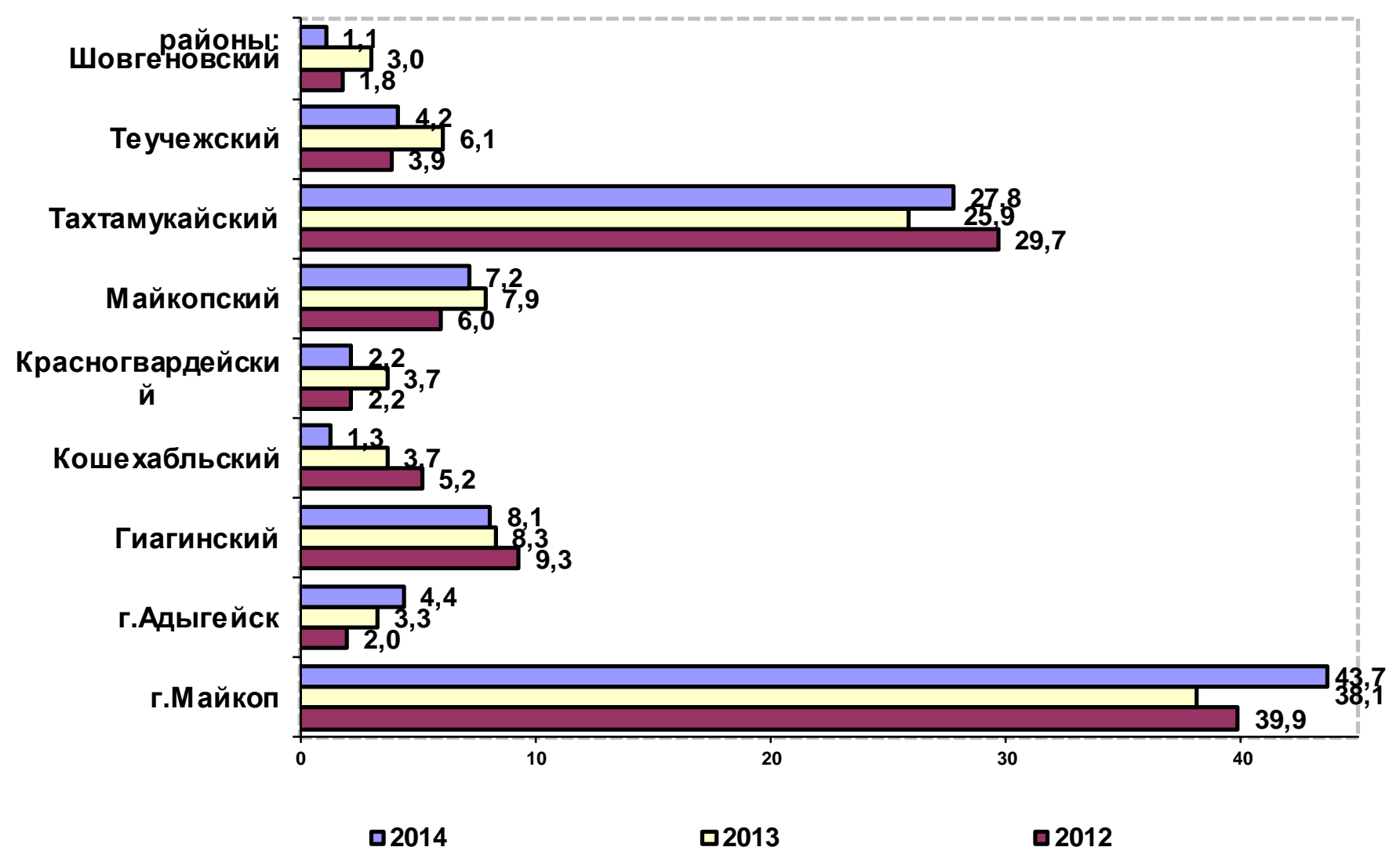

Рисунок 1 - Структура оборота по районам Республики Адыгея, в \% к итогу

В среднем $68 \%$ от общей величины оборота в 2012-2014 годах приходилось на малые предприятия г. Майкопа и Тахтамукайского района. Максимальный рост оборота в 2014 году наблюдался в г. Адыгейске (за период в 2,3 раза). Наиболее значительное снижение оборота произошло в Кошехабльском районе - в 3,9 раза против величины 2012 года и в 2,4 раза против 2013 года. Основная причина значительного изменения оборота - миграция предприятий из типа «малое» в тип «среднее» по критерию «выручка».

\section{Таблица 4 - Оборот малых предприятий по районам Республики Адыгея}

\begin{tabular}{|c|c|c|c|c|c|}
\hline & $\begin{array}{c}2012 \\
\text { (млн. руб.) }\end{array}$ & $\begin{array}{c}2013 \\
\text { (млн. руб.) }\end{array}$ & $\begin{array}{c}2014 \\
\text { (млн. руб.) }\end{array}$ & $\begin{array}{c}2014 \text { в \% } \\
\kappa 2013\end{array}$ & $\begin{array}{c}2013 \text { в \% } \\
\kappa 2012\end{array}$ \\
\hline Всего & 25208,5 & 21647,5 & 26262,1 & 121,3 & 85,9 \\
\hline \multicolumn{6}{|l|}{ в том числе: } \\
\hline г. Майкоп & 10049,6 & 8242,2 & 11480,7 & 139,3 & 82,0 \\
\hline г. Адыгейск & 500,0 & 723,8 & 1145,2 & 158,2 & 144,8 \\
\hline \multicolumn{6}{|l|}{ районы: } \\
\hline Гиагинский & 2355,9 & 1787,8 & 2121,6 & 118,7 & 75,9 \\
\hline Кошехабльский & 1315,9 & 808,0 & 337,8 & 41,8 & 61,4 \\
\hline Красногвардейский & 564,8 & 808,0 & 586,0 & 72,5 & 143,1 \\
\hline Майкопский & 1512,7 & 1717,7 & 1891,6 & 110,1 & 113,6 \\
\hline Тахтамукайский & 7490,6 & 5592,5 & 7301,8 & 130,6 & 74,7 \\
\hline Теучежский & 974,6 & 1314,3 & 1109,2 & 84,4 & 134,9 \\
\hline Шовгеновский & 444,4 & 653,2 & 288,2 & 44,1 & 147,0 \\
\hline
\end{tabular}


Общий прирост оборота малых предприятий республики по сравнению с 2012 годом на $61 \%$ был обеспеченпредприятиями г. Адыгейска, по сравнению с 2013 годом на 70\% - предприятиями г. Майкопа.

По сопоставимому кругу организаций рост оборота в реальном выражении в 2014 году обеспечили 135 малых предприятий (29,5\% от общего числа), в том числе 70 предприятий в г. Майкопе и 28 - в Тахтамукайском районе.

Около половины оборота малого бизнеса в 2014 году приходится на предприятия оптовой и розничной торговли; по ремонту автотранспортных средств, мотоциклов, бытовых изделий и предметов личного пользования (47,5\%, увеличение на 9,6 процентного пункта против
2012 года), около пятой части - на предприятия обрабатывающих производств (18,8\%, уменьшение на 2,8 процентного пункта) и около шестой части - на строительные организации (15,6\%, снижение на 1,8 процентного пункта).

Инвестиционная активность малых предприятий Республики Адыгея в 2012-2014 годах была нестабильна. Инвестиции малых предприятий в основной капитал в 2014 году составили 721,5 млн. рублей, что на 47,7\% меньше, чем в 2013 году и на 39,2\% меньше, чем в 2012 году. Индекс физического объемаинвестиций в основной капитал в 2014 году по сравнению с 2013 годом составил 46,9\%, в 2013 году по сравнению с 2012 годом - 108,8\%.

Таблица 5 - Инвестиции в основной капитал в разрезе районов Республики Адыгея

\begin{tabular}{|c|c|c|c|c|c|c|c|c|}
\hline & \multicolumn{2}{|c|}{2012} & \multicolumn{3}{|c|}{2013} & \multicolumn{3}{|c|}{2014} \\
\hline & $\begin{array}{c}\text { млн. } \\
\text { рублей }\end{array}$ & $\begin{array}{c}\text { в\% } \\
\kappa \text { итогу }\end{array}$ & $\begin{array}{c}\text { млн. } \\
\text { рублей }\end{array}$ & $\begin{array}{c}\text { в\% } \\
\kappa \text { итогу }\end{array}$ & $\begin{array}{l}\% \% \kappa \\
2012\end{array}$ & $\begin{array}{c}\text { млн. } \\
\text { рублей }\end{array}$ & $\begin{array}{c}\text { в\% } \\
\kappa \text { итогу }\end{array}$ & $\begin{array}{l}6 \% \kappa \\
2013\end{array}$ \\
\hline Всего & 1185,8 & 100,0 & 1379,6 & 100,0 & 116,3 & 721,5 & $\mathbf{1 0 0 , 0}$ & 52,3 \\
\hline в том числе: & & & & & & & & \\
\hline г. Майкоп & 249,2 & 21,0 & 290,1 & 21,0 & 116,4 & 160,5 & 22,3 & 55,3 \\
\hline г. Адыгейск & 3,9 & 0,3 & 25,0 & 1,8 & в $6,4 \mathrm{p}$. & 12,1 & 1,7 & 48,4 \\
\hline районы: & & & & & & & & \\
\hline Гиагинский & 205,9 & 17,4 & 601,0 & 43,6 & в 2,9p. & 181,3 & 25,1 & 30,2 \\
\hline Кошехабльский & 30,0 & 2,5 & 7,9 & 0,6 & 26,3 & 13,9 & 1,9 & 175,9 \\
\hline Красногвардейский & 48,6 & 4,1 & 31,1 & 2,3 & 64,0 & 24,6 & 3,4 & 79,1 \\
\hline Майкопский & 88,7 & 7,5 & 88,9 & 6,4 & 100,2 & 75,0 & 10,4 & 84,4 \\
\hline Тахтамукайский & 495,8 & 41,8 & 318,2 & 23,1 & 64,2 & 214,6 & 29,7 & 67,4 \\
\hline Теучежский & 48,8 & 4,1 & 11,5 & 0,8 & 23,6 & 22,9 & 3,2 & 199,1 \\
\hline Шовгеновский & 14,9 & 1,3 & 5,9 & 0,4 & 39,6 & 16,6 & 2,3 & в $2,8 \mathrm{p}$. \\
\hline
\end{tabular}

Из муниципальных образований Республики Адыгея наибольший объем инвестиций малого бизнеса привлекли Гиагинский, Тахтамукайский районы и г. Майкоп (свыше 77\% в 2014г.). Инвестиционный вклад малых предприятий Гиагинского района по сравнению с 2012 годом увеличился на 7,7\%,г. Майкопа - 1,3\%. Ростинвестиций в 2013 годубыл обеспеченсельскохозяйственными малыми предприятиями Гиагинского района в части развития садоводства. В
Тахтамукайском районе и г. Майкопе основной объем инвестиций был направлен на строительство складских помещений и жилых домов.

В 2014 году инвестиционная активность в целом по Республике Адыгея значительно уменьшилась в связи с завершением ряда инвестиционных проектов. Рост объема инвестиций наблюдался только в Шовгеновском, Теучежском и Кошехабльском районах, доля которых 
в общем объеме инвестиций малых предприятий в 2012-2014гг. не превышала 8\% [6].

Последствия кризиса, отразившиеся на экономике всех регионов РФ, в значительной степени затронули предприятия малого бизнеса, что привело к снижению инвестиционной активности, замедлению темпов прироста оборота, сокращению численности постоянных работников и реальных зарплат. При этом роль малого бизнеса в экономике Республики Адыгея возросла. Доля малых предприятий (включая микропредприятия) в структуре производства ВРП Республики Адыгея существенно возросла.

При этом приоритетным направлением развития субъектов малого и среднего бизнеса Рес- публики Адыгея является развитие взаимодействия с крупными корпоративными структурами, внерегиональными инвестиционным и пулами [7].

Таким образом, проведенный анализ показал, что малый бизнес Республики Адыгея характеризуется следующими особенностями: во-первых, подвержен тем же кризисогенным факторам, что и другие сектора экономики Республики Адыгея; во-вторых, крайне неравномерно дислоцирован по территории Республики Адыгея. При этом учет территориальноотраслевых особенностей региона играет важную роль при регулировании деловой активности субъектов малого предпринимательства.

\section{ЛИТЕРАТУРА}

1. О Концепции долгосрочного социально-экономического развития Российской Федерации на период до 2020 года: Распоряжение Правительства РФ от 17.11.2008 № 1662 -р (ред. от 08.08.2009 № 1121 -р). // Информационно-правовой портал «КонсультантПлюс» [Электронный ресурс]. http://base.consultant.ru/cons/cgi/online.cgi ?req=doc;base=Law;n=90601 .

2. Интернет-ресурс «Малый бизнес в Республике Адыгея» [Электронный ресурс]. - Peжим доступа: http://sbra.ru/.

3. Итоги развития малого предпринимательства за 2015 года // Интернет-ресурс «Министерство экономического развития и торговли Республики Адыгея» [Электронный ресурс]. - Режим доступа: http://www.minecora.ru/doc/Itog_2014.doc.

4. Рейтинг регионов по предпринимательской активности// Интернет-ресурс «Клуб регионов» [Электронный ресурс]. - Режим доступа: http://club-rf.ru/theme/388.

5. Тхакушинова, С.А. Инвестиционная привлекательность региона на примере Республики Адыгея // Экономика и управление в современных условиях: проблемы и перспективы: сборник научных трудов по материалам 2 Международной научно-практической конференции, 2015. - С. 148-155.

6. Интернет-ресурс «Территориальный орган государственной статистики по Республики Адыгея» [Электронный ресурс]. - Режим доступа: http://www.adg.gks.ru/.

7. Мокрушин, А.А. Стратегические приоритеты развития региональных экономических систем // Вестник Адыгейского государственного университета. Серия 5: Экономика, 2010. № 3 - С. 134-136.

8. Апишев, А.А. Стартовые условия вхождения регионального АПК в рынок / А.А. Апишев, А.А. Тамов, М.К. Тамова // Вестник Адыгейского государственного университета. Серия 5: Экономика, 2015. № 3 (165). - С. 215-219.

9. Тамов, А.А. Роль агропромышленного комплекса в реализации региональных интересов // Экономист, 2002. №4. С. 84. 


\section{«ОЛИМПИЙСКОЕ НАСЛЕДИЕ» КАК ФАКТОР ПОВЫШЕНИЯ АТТР АКТИВНОСТИ СОЧИНСКОЙ ДЕСТИНАЦИИ}

Ковалева М.К. аспирант, Майкопский государственный технологический университет, г. Майкоп

Аннотация. В статье рассматриваются особенности формирования аттрактивности дестинации в цеелом и организации аттрактивных событий, в частности. Проанализирован опыт использования «олимпийского наследия» в контексте повышения степени аттрактивности города-курорта Сочи.

Ключевые слова: аттрактивность, «олимпийское наследие», искусственная аттракция, событийный туризм.

\section{"OLYMPIC LEGACY" AS A FACTOR OF SOCHI DESTINATION ATTRACTIVENESS Post-Graduate student, Maikop State Technological University, Maikop

\begin{abstract}
The paper discloses the peculiarities of the destination attractiveness formation as a whole and the organization of attractive events in particular. The author studies the experience in the use of "Olympic legacy" in improving the degree of Sochi attractiveness.

Keywords: attractiveness, "Olympic legacy", artificial attraction, eventful tourism.
\end{abstract}

Kovalyova M.K.

Одним из ключевых параметров, имманентно присущих любой дестинации, является ее аттрактивность, которая определяется специалистами в качестве основного системного свойства туристских ресурсов, свидетельствующего об их туристской ценности [3, c. 89]. Как отмечает О.А. Артемьева, аттрактивность является способностью туристского ресурса привлекать к себе внимание посетителей дестинации, тем самым мотивируя и стимулируя их к туристскому путешествию. Аттрактивность являет собой качественную характеристику туристского ресурса, в то время как ее физическим воплощением является формирование аттракции, т.е. создание на основе туристского ресурса определенных объектов, побуждающих интерес туристов, доступных для них и формирующих позитивное восприятие дестинации [1, с. 12].

При этом степень аттрактивности дестинации определяется соотношением доступности этих объектов и восприятия их важности [7, с. 11]. Таким образом, с экономической точки зрения об аттрактивности позволяет судить зависимость между элементами туристского предложения и туристским спросом.

В современных условиях развития туристического бизнеса все большее внимание привлекают к себе объекты искусственной аттракции, т.е. объекты показа, которые целенаправленно создаются с целью привлечения внимания туристов вне контекста культурноисторического наследия и природных ресурсов дестинации [4, с. 108]. Подобные объекты во многих случаях становятся тем базисом, на котором создается специфический туристский продукт, созданный целевым образом. Вследствие этого, формирование туристского продукта, основанного на искусственной аттракции, становится действенным инструментом повышения туристского потенщиала территории. При этом к числу основных условий формирования искусственной аттракции относят [2, с. 40]:

- основанность на концептуальном туристском ресурсе;

- способность привлечь интерес; 
- включенность в системы и источники распростране ния туристской информации;

- высокая туристская доступность;

- способность к формированию позитивного восприятия дестинации.

Одними из важнейших объектов искусственной аттракции являются т.н. «аттракт ивные события» - проводящиеся единовременно или на традиционной основе культурные, спортивные, деловые и т.п. мероприятия, способствующие повышению туристской привлекательности места проведения данных событий. Особое место в ряду подобных событий занимают летние и зимние Олимпийс кие игры, что во многом объясняется формированием в процессе их проведения т.н. «олимпийского наследия», характеризуемого в качестве комплекса материальных и нематериальных последствий для принимающей территории, возникающих вследствие проведения в еe рамках указанных мегаспортивных событий.

Проведение в 2014 году XXII зимних Олимпийских игр обусловило формирование качественно нового туристского пространства как совокупности элементов разнообразной природы и назначения, обеспечивающих аттрактивность Сочи как специфической постолимпийской дестинации. К их числу, помимо местных достопримечательностей, традиционно обладавших аттрактивным потенциалом, относятся комплекс объектов олимпийского наследия, приведенная в соответствие с международными стандартами инфраструктура, новые туристские маршруты, комплекс туристских услуг международного уровня качества и диверсифицированный туристский продукт.

В этой связи можно констатировать, что помимо повышения степени аттрактивности сочинской дестинации, проведение зимних Олимпийских игр 2014 года, обусловило осуществление следующих трансформационных изменений в контексте обеспечения туристической привлекательности новой олимпийской столицы $[5$, с. 55]:

1. ориентированный преимущественно на организацию летнего пляжного отдыха курорт трансформируется в международный круглогодичный центр по оказанию широкого спектра туристских услуг;

2. модернизация городской инфраструктуры привела к появлению новых предприятий размещения высокого класса обслуживания, что способствует продвижению дестинации как курорта мирового уровня;

3. в городе формируется новый кластер туристских предприятий, ориентированных на спортивный, событийный и деловой туризм.

Однако необходимо отметить, что проведение единовременного аттрактивного события (даже такого крупного как Олимпийс кие игры) обеспечивает получение положительного эффекта для развития туристической сферы лишь в рамках жизненного цикла, присущего этому событию.

В этой связи ключевой задачей в рамках реализации аттрактивного эффекта подобного события является формирование событийного ряда менее значимых мероприятий различного профиля, как правило, проводящихся в традиционные сроки. Наличие объектов «олимпийского наследия» и развитой инфраструктуры, а также имидж олимпийской столицы позволяют сформировать очень привлекательную площадку для проведения таких мероприятий в контексте сохраняющегося повышенного интереса со стороны потенциальных участников этих событий, туристов, инвесторов и других заинтересованных лиц, что, в свою очередь, повышает степень аттрактивности туристской дестинации.

При этом специалисты указывают на желательность формирования цельного событий- 
ного пакета с фиксированными датами мероприятий, описанием организационных и экономических механизмов, обеспечивающих их проведение. В подобном случае аттрактив ные мероприятия позволят привлечь больший поток туристов вследствие обеспечения возможности бронирования мест размещения, планирования транспортных маршрутов к месту проведения мероприятий и т.п. [6, с. 47]
В этой связи одной из важнейших задач в рамках управления «олимпийским наследием» является грамотное выстраивание системы событийных мероприятий, использующих материальный и нематериальный потенциал данного наследия с целью обеспечения высокой аттрактивности региона проведения Олимпийских игр в постсоревновательный период.

\section{ЛИТЕРАТУРА}

1. Артемьева, О.А. Формирование туристских продуктов, основанных на искусственной аттракции: дис. ... канд. экон. наук. - М., $2011-246$ с.

2. Гурьева, М.В. Аттрактивный потенциал как фактор социально -экономического развития территории: дис. ... канд. экон. наук. - СПб., 2015 - 252 с.

3. Зорин, И.В. Туристский терминологический словарь. / И.В. Зорин, В.А. Квартальнов // - М.: Советский спорт, $1999-167$ с.

4. Казакова, С.А. Методы рыночного позиционирования турпродуктов, основанных на искусственной аттракции // Сервис в России и за рубежом, № 2, 2012 - С. 69-71.

5. Кружков, Д.А. Роль олимпийского наследия в развитии туристской инфраструктуры Краснодарского края / Д.А. Кружков, Н.М. Мартыненко // Материалы научной и научно-методической конференции профессорско-преподавательского состава Кубанского государственного университета физической культуры, спорта и туризма, № $2,2015-$ C.56-57.

6. Кулишкин, Д.Ю. Социально-экономические проблемы постолимпийского развития городов: туристский аспект // Науковедение. - 2015, № 3-C. 13-15.

7. Formica S. Destination attractiveness as a function of supply and demand interaction. Blacksburg, $2000-$ P. 11. 


\title{
ОСОБЕННОСТИ И ПРОБЛЕМЫ ЭКОНОМИЧЕСКОГО СОТРУДНИЧЕСТВА КРАСНОДАРСКОГО КРАЯ И РЕСПУБЛИКИ АДЫГЕЯ
}

Меджидов Ш.М.

Магистрант II курса, Адыгейский государственныий университет, г. Майкоп

Научный руководитель: Пиизова А.P.

кандидат экономических наук, доиент,

Адыгейский государственный университет, г. Майкоп

\begin{abstract}
Аннотация. В статье рассматриваются различные аспекты экономического сотрудничества Краснодарского края и Республики Адыгея, как двух смежных регионов. Особое внимание уделено факторам, стимулирующим и сдерживающим развитие межрегиональных экономических связей.

Ключевые слова: регион, сотрудничество, Краснодарский край, Республика Адыгея, региональная экономика, фактор, потенциал, стратегия, структура.
\end{abstract}

\section{FEATURES AND CHALLENGES FOR ECONOMIC CRASNODAR REGION AND REPABLIC ADYGEA}

Mejidov Sh.M.

Undergraduate of 2 courses, Adyghe State University, Maikop Supervisor: Pshizova A.R.

PhD, Associate Professor, Adyghe State University, Maikop

\begin{abstract}
The article discusses the various aspects of economic cooperation between Krasnodar Region and the Republic of Adygea, as the two adjacent regions. Particular attention is paid to the factors that stimulate and inhibit the development of inter-regional economic relations.

Keywords: region, cooperation, Krasnodar Territory, the Republic of Adygea, regional economy, factor, capacity, strategy, structure
\end{abstract}

Характер и интенсивность экономического сотрудничества Краснодарского края и Республики Адыгея зависят не только от факторов общего характера, которым подвержены практически все соседние регионы. Они зависят еще от целого комплекса других факторов, в числе которых наиболее значимыми, на наш взгляд, являются следующие:

- особенности географического положения обоих регионов;

- экономическое взаимодействие этих регионов в прошлом;

- позиционирование обоих регионов в пространстве ЮФО и страны в целом;

- реализуемые обоими регионами стратегии социально-экономического развития [1].

В целом, геоэкономическое положение и производственно-экономический потенциал Краснодарского края позволяют развивать экономические взаимосвязи на взаимовыгодной основе с любым регионом Юга России, чего нельзя сказать о Республике Адыгее, которая и по масштабам, и по потенциалу, значительно уступает и Краснодарскому краю, и наиболее развитым регионам ЮФО. Для экономики Республики Адыгея характерны: преобладание низкорентабельных отраслей, трудно адаптирующиеся к условиям рынка; высокая доля неорганизованного сельскохозяйственного производства, торговли, транспорта, составляющих основу теневой экономики.

Следует отметить, что территориальная организация хозяйства Республики Адыгея характеризуется неравномерностью размещения имеющегося потенциала и концентрацие й его, прежде всего, в г. Майкопе, причем эта 
неравномерность имеет тенденцию к усилению. Указанная неравномерность препятствует развитию межмуниципальных связей между районами Краснодарского края и сельскими районами Республики Адыгея.

Из других факторов, препятствующих активизации экономического взаимодействия Краснодарского края и Республики Адыгея, следует привести асимметричные позиции их в пространстве Южного макрорегиона. Краснодарский край является одним из наиболее крупных регионов ЮФО, бюджетно-обеспеченных, занимающих лидирующие позиции по многим важнейшим показателям. Республика Адыгея, несмотря на ряд позитивных изменений в последние годы, все еще остается сильно дотационным регионом с неустойчивой экономикой, перспективы которого во многом обусловлены финансовой помощью Центра. В этих условиях сильно дотационному региону сложно проводить самостоятельную финансово обеспеченную стратегию развития, важной составляющей которой является стратегия межрегионального взаимодействия.

Если перейти к факторам, благоприятствующим активизации экономического сотруднического двух соседних регионов, то следует, прежде всего, указать на близость отраслевой структуры их экономик, в которых важные позиции занимают АПК и туристско-рекреационный комплекс, которые в обоих регионах считаются наиболее приоритетными. В то же время в структуре ВРП рассматриваемых регионов есть и серьезные различия, в частности, по транспорту и связи, что может также служить направлением активизации взаимодействия в смысле подключения Республики Адыгея к системному развитию общей инфраструктуры единой с экономикогеографической точки зрения территории.
Отсутствие достоверной статистической информации по многим аспектам, характеризующим межрегиональные связи Краснодарского края и Республики Адыгея, как и между ними и остальными регионами Южного федерального округа, косвенно подтверждает наличие серьезных проблем как исследовательского, так и управленческого характера в сфере межрегиональных экономических связей вообще.

Тем не менее, имеющиеся данные позволяют получить представления о структуре и динамике товарооборота. Из Краснодарского края в Республику Адыгея поступают: листы асбестоцементные (шифер), продукция деревообрабатывающей промышленности, телевизоры, магнитофоны, холодильники бытовые, машины швейные, машины стиральные, компьютеры, электропылесосы, кожгалантерейные изделия, ювелирные изделия, посуда фарфорофаянсовая, лакокрасочные материалы в мелкой расфасовке, пленки полимерные, удобрения минеральные, станки деревообрабатывающие, насосы центробежные, кабель телефонной связи, молоко и молочные изделия, кондитерские изделия, крупы, сахар, рыба, пиво, спирт этиловый, колбасные изделия и т.П.

В целом, Республика Адыгея, как и Краснодарский край, практически самодостаточна по наличию продовольственных товаров на ее рынках, так как объем производства почти по всем видам продукции значительно превышает ее ввоз извне. Исключение в основном составляют товары, производство которых по климатическим причинам в нашей республике невозможно или экономически нецелесообразно. Это цитрусовые культуры, чай, кофе, рыбные консервы, соль, а также шелковые ткани, шерстяные ткани, ковры и табачные изделия. Из Республики Адыгея в Краснодарский край поставляют: пиломатериалы, фанера склеенная, картон, щебень и гравий, 
мука, цельномолочная продукция, сыры жирные, мяса и птицы, водка и ликероводочные изделия, вина виноградные и т.п. [2].

В целом, для поставок товаров из Краснодарского края в Республику Адыгея и из Республики Адыгея в Краснодарский край характерны нестабильность, отсутствие устойчивых тенденщий роста или снижения. Указанное явление имеет место при устойчивом росте объемов производства потребительских товаров и общих объемов товарооборота на внутренних рынках обоих регионах.

В последние годы имеет место преобладание вывоза товаров из Республики Адыгея в Краснодарский край над ввозом из края в республику, что сложно однозначно объяснить, поскольку такая ситуация может быть связана с неполным охватом статистикой всего объема товарооборота, что было отмечено выше, хотя, вероятно, имеет место и недостоверность данных, и отражение в статистике реальных потребностей потребителей Республики Адыгея в товарах, производимых в Краснодарском крае.

Особо следует отметить сотрудничество между исследуемыми регионами в агропромышленной сфере, включая закупки молочного сырья молочными заводами Адыгеи на территории края, активные контакты населения близлежащих мунищипальных образований (Кошехабльского,. Шовгеновского, Гиагинского районов Республики Адыгея с Белореченским, Курганинским и Лабинским районами Краснодарского края) по реализации продукции подворья, особенно плодоовощного сырья.

Что касается иных форм проявления экономического взаимодействия (ввоз и вывоз капиталов, услуг, перемещение рабочей силы между регионами и т.д., то отсутствие достоверной статистической информации по Краснодарскому краю и Республике Адыгея не позволяет получить объективные представления о масштабах такого взаимодействия. В то же время, проведенный анализ позволил выявить, что:

- значительная часть трудоспособного населения близлежащих к Краснодару муниципальных образований Республики Адыгея работают в г. Краснодаре;

- устойчиво растет количество выпускников школ Краснодарского края и Республики Адыгеи, обучающихся в вузах соседнего региона;

- в процессе миграционного перемещения молодежи и квалифицированных специалистов между исследуемыми регионами большую долю составляет поток из Республики Адыгея в Краснодарский край, главным образом, в г. Краснодар;

- в связи с расширением в последние годы строительства крупных торговых и торговоразвлекательных комплексов на территории Республики Адыгея, близлежащей к г. Краснодару, непрерывно увеличивается объем товарооборота и услуг, оказываемых в республике в том числе и за счет жителей Краснодарского края;

- существенную часть отдыхающих в Майкопском районе составляют жители Краснодарского края, причем все большее развитие получает корпоративный отдых в выходные дни; расширяется поток отдыхающих из г. Майкопа в Белореченском районе Краснодарского края.

Если систематизировать качественные признаки экономического взаимодействия Краснодарского края и Республики Адыгея, то можно сделать вывод о том, что: ресурсу взаимодействия друг с другом не придается должного значения; наибольший позитив ны й эффект от их взаимодействия имеет место в тех сферах, где оно опирается на потенциальный конкурентные преимущества обоих реги- 
онов, обусловленные их природно-ресурсными, географическими, производственноэкономическими и прочими особенностями; имеются значительные резервы, как на межрегиональном, так и на межмуниципальном и межхозяйственном уровнях для активизации взаимовыгодного сотрудничества указанных регионов[3, 4].

Географическое положение и природно-ресурсный потенщиал двух соседних регионов «обрекают» их на взаимодействие по направлениям: развитие сферы туристско-рекреационных услуг на взаимодополняемой основе; производство агропромышленной продукции с учетом общей сырьевой зоны, удовлетворяющей потребности перерабатывающих предприятий обоих регионов; производство строительных материалов для нужд обоих регионов; строительство инфраструктурных объектов на близлежащих к Краснодару территориях Республики Адыгея.

\section{ЛИТЕРАТУРА}

1. Архангельский, В.Н. Эффективность функционирования экономики региона. Межрегиональные потоки и товарная специализация регионов. Учебное пособие. - M: Изд-во РАГС, 2015. - 72 с.

2. Тамов, А.А. Теоретико-методологические аспекты исследования межрегиональной социально -экономической дифференциации в пространстве макрорегиона / А.А. Тамов, А.Г. Добровольский // Вестник Адыгейского государственного университета. Сер. 5, Экономика. - Майкоп: Изд-во АГУ, 2013. Вып. 2(115). - С. 71-76.

3. Тамов, А.А. К вопросу о системном моделировании регионального АПК в рыночных условиях / А.А. Тамов, М.Г. Коваленко // Вестник Адыгейского государственного университета. Сер. 5, Экономика. - Майкоп: Изд-во АГУ, 2013. - Вып. 4. - С. 182185.

4. Мокрушин А.А. Перспективы развития межрегиональной агропромышленной интеграции в условиях глобализации южно-российской экономики // Национальные интересы: приоритеты и безопасность, 2008. № 12. - С. 70-75.

5. Мокрушин, А.А. Корпоративное управление интеграционными трансакциями в АПК региона: функциональные особенности, критерии эффективности / А.А. Мокрушин, С.В. Кесян // Новые технологии, 2013. № 4. - С. 61-67. 


\title{
СРАВНИТЕЛЬНЫЙ АНАЛИЗ РЕГИОНАЛЬНЫХ ПРОГРАММ СОЦИАЛЬНО- ЭКОНОМИЧЕСКОГО РАЗВИТИЯ РЕСПУБЛИКИ АДЫГЕЯ
}

Мукба А.В.

Магистрант II курса, Адыгейский государственный университет, г. Майкоп

Научный руководитель: Пииканокова Н.И. к.э.н., профессор, Адьгейский государственньй университет, г. Майкоп

\begin{abstract}
Аннотация. В статье в сравнительном плане рассматривается ряд аспектов, характеризуюших особенности региональных программ сочиильно-экономического развития, реализованных в Республике Адыгея. Особое внимание уделено оченке ключевых мероприятий обеих программ по их роли в обеспечению динамичного развития региона.

Ключевые слова: программа, сочиально-экономическое развитие, конкурентные преимущества, инструмент, структура, ресурсы, стратегия, механизмы.
\end{abstract}

\section{COMPARATIVE ANALYSIS OF REGIONAL PROGRAMMES FOR SOCIAL AND ECONOMIC DEVELOPMENT OF THE REPUBLIC ADYGEA}

Mukba A.V.

Undergraduate of 2 courses, Adyghe State University, Maikop

Supervisor: Pshikanokova N.I.

Ph.D., professor, Adyghe State University, Maikop

\begin{abstract}
In an article in the comparative plan addresses a number of aspects that characterize the features of the regional programs of socio-economic development, implemented in the Republic of Adygea. Particular attention is paid to the evaluation of the key measures of both programs on their role in ensuring the dynamic development of the region.

Keywords: program, socio-economic development, competitive advantages, tools, structure, resources, strategies, mechanisms.
\end{abstract}

За последние годы, несмотря на продолжающийся финансово-экономический кризис в российской экономике, в регионах стали уделять все больше внимания среднесрочным программам, под которыми мы понимаем согласованный и увязанный по ресурсам, исполнителям и срокам комплекс различных мероприятий, реализуемых при поддержке органов региональной власти и обеспечивающих наиболее эффективное решение важнейших задач регионального развития. Вместе с тем, в силу недостаточной научно-методической обеспеченности разработчиков программ, многочисленных проблем, связанных с их реализацией, главным образом, - ресурсным обеспечением, на практике далеко не всегда удается в полной мере раскрыть потенциальные возможности этого инструмента [1].
За последние 20 лет в Республике Адыгея в полномасштабном формате были разработаны и реализованы две региональные программы - Федеральная целевая программа «Социально-экономическое развитие Республики Адыгея на 1997-2000 годы» и «Программа экономического и социального развития Республики Адыгея на 2004-2008 годы», которые были включены в Федеральный реестр региональных программ [2,3].

Указанные среднесрочные программы имели в качестве объекта программного развития один и тот же регион и содержат в себе много общего. Основная их цель состоит в повышении уровня жизни населения республики. В то же время, охватывая различные периоды развития региона и потому призванные решать неодинаковые задачи, к тому же раз- 
работанные на различной методической основе и различными авторскими коллективами, эти программы существенно различаются.

Так, в программе «Социально-экономическое развитие Республики Адыгея на 19972000 годы» акцент сделан на преодоление тенденций спада в экономике республики и постепенную стабилизацию производства в основных отраслях ее экономики, рост финансового потенциала и снижение дотационности регионального бюджета. Эти меры направлены на противодействие факторам и последствиям наиболее сложного начального периода рыночных реформ в российской экономике.

Программу экономического и социального развития Республики Адыгея на 2004-2008 гг. разрабатывали в период, когда качественно улучшилась общеэкономическая ситуация , стали проявляться позитивные тенденции в социально-экономическом развитии региона. В таких условиях разработчики этой программы сочли необходимым поставить в ней ряд амбициозных задач, включая задачу повышения конкурентоспособности региона, что получило отражение в той или иной мере в структуре программы, в структуре целей; в системе программных мероприятий; в приоритетах программ и, наконец, в ресурсном обеспечении программы и механизмах еe peaлизации.

Приоритеты в каждой программе были определены исходя из задач, поставленных разработчиками для реализации главной цели - повышения уровня жизни населения региона (табл. 1).

\section{Таблица 1 - Стратегические задачи ФЦП «Социально-экономическое развитие Республики Адыгея на 1997-2000 годы» и Программы экономического и социального развития Республики Адыгея на 2004-2008 годы [2,3].}

\begin{tabular}{|c|c|}
\hline $\begin{array}{l}\text { Программа развития Республики Адыгея на } \\
\text { 1997-2000 гг. }\end{array}$ & $\begin{array}{l}\text { Программа развития Республики Адыгея на } \\
2004-2008 \text { гг. }\end{array}$ \\
\hline $\begin{array}{l}\text { 1. Обеспечение экономического роста и фи- } \\
\text { нансовой стабилизации в регионе }\end{array}$ & $\begin{array}{l}\text { 1. Сокращение отставания региона по показа- } \\
\text { телю производства ВРП на душу населения. }\end{array}$ \\
\hline $\begin{array}{l}\text { 2. Улучшение условий для предприниматель- } \\
\text { ской активности }\end{array}$ & $\begin{array}{l}\text { 2. Повышение инвестиционной привлекательно- } \\
\text { сти региона }\end{array}$ \\
\hline $\begin{array}{l}\text { 3. Привлечение отечественных и иностран- } \\
\text { ных инвесторов }\end{array}$ & $\begin{array}{l}\text { 3. Обеспечение опережающего роста собствен- } \\
\text { ных доходов бюджета }\end{array}$ \\
\hline $\begin{array}{l}\text { 4. Рациональное использование уникальных } \\
\text { природно-климатических и рекреационных } \\
\text { ресурсов }\end{array}$ & 4. Значительное снижение общей безработицы \\
\hline $\begin{array}{l}\text { 5. Резкое уменьшение зависимости бюджета } \\
\text { республики от федеральных трансфертов }\end{array}$ & 5. Реш \\
\hline $\begin{array}{l}\text { 6. Создание благоприятной социальной об- } \\
\text { становки в районах }\end{array}$ & $\begin{array}{l}\text { вление ситуации в зоне Краснодарского } \\
\text { илища }\end{array}$ \\
\hline 7. Оздоровление & \\
\hline
\end{tabular}

Как видно из табл. 1, в Программе развития Адыгеи на 2004-2008 гг. почти вдвое больше программных мероприятий. При этом в первой программе в качестве приоритетных секторов экономики рассматриваются АПК, топливно-энергетический комплекс и промыш- ленный комплекс, тогда как во второй - туристско-рекреационный комплекс, агропромышленный комплекс и промышленный комплекс, включая транспорт и связь.

В то же время, заслуживают внимания те программные мероприятия более поздней программы, которые оказались в разделе 
«прочие мероприятия», включая мероприятия по созданию благоприятного инвестицио нного и предпринимательского климата в регионе. Подобных мероприятий в Программе 1997-2000 гг. не было, что является серьезным преимуществом и достоинством второй программы.

Обосновывая ресурсное обеспечение, разработчики обеих программ исходили из общеэкономической ситуации, а также из текущего состояния и прогнозов развития экономики региона. Что касается первой программы, то при определении сценариев развития экономики Республики Адыгея, которые были положены в основу этого документа, не были в достаточной степени учтены экономические реалии того периода. Был выбран сценарий инвестиционного типа, базирующийся на одновременном развитии всех основных секторов экономики региона. Будучи расплывчатой по целям, охватив практически всю экономику Адыгеи, рассчитанная на ресурсное обеспечение, которого ни по внешним, ни по внутрирегиональным источникам не могло быть, Программа 1997-2000 года изначально была обречена на значительное недовыполнение, что характерно для практики финансирования Федеральных среднесрочных программ того периода. К сожалению, такая же участь постигла и вторую из рассматриваемых программ.

Вместе с тем, обе рассматриваемые программы сыграли положительную роль в социально-экономическом развитии исследуемого региона. Во многом благодаря этим программам, республика, начиная с 1997 года, вплоть до разработки в 2008 г., когда была разработана и принята Стратегии развития Адыгеи до 2025 года, имела определенный сценарий развития, а управленческие кадры, участвовавшие в разработке и реализации программ, приобрели соответствующий опыт. Были привлечены значительные средства из федерального бюджета на развитие республики.

\section{ЛИТЕРАТУРА}

1.Тамов, А.А. Методологические аспекты формирования системы стратегического управления экономикой муниципального образования / А.А. Тамов, А.В. Науменко // Вестник Адыгейского государственного университета. Сер. 5, Экономика. - Майкоп: Изд-во АГУ, 2011 . Вып. 2(87). - С. 45-49.

2. Федеральная целевая программа «Социально-экономическое развитие Республики Адыгея на 1997-2000 гг.» / Советская Адыгея, 1997 - 2007- 17 апреля.

3. Программа экономического и социального развития Республики Адыгея на 20042008 годы / Советская Адыгея, 2004 - 9 марта. 


\title{
ОСОБЕННОСТИ ДИВЕРСИФИКАЦИИ ЭКОНОМИКИ КАК ИНСТРУМЕНТА СБАЛАНСИРОВАННОГО РАЗВИТИЯ РЕГИОНА
}

Мырадов С.Б.

Магистрант I курса, Адыгейский государственный университет, г. Майкоп

Научный руководитель: Тамов А. А. доктор экономических наук, профессор, Адыгейский государственный университет, г. Майкоп

\begin{abstract}
Аннотация. В статье рассматриваются особенности диверсификации как инструмента развития регионов Северного Кавказа на примере Республики Адыгея. Особое внимание уделено активизации процессов диверсификаџии в сельских районах Республики Адыгея. Ключевые слова: диверсификация, сбалансированное развитие, республика, Северный Кавказ, потенциал, стратегия.
\end{abstract}

\section{FEATURES DIVERSIFY THE ECONOMY AS INSTRUMENT OF BALANCED REGIONAL DEVELOPMENT}

Myradov S.B. Master of I course, Adyghe State University, Maikop

Supervisor: AA Tamov Doctor of Economics, professor, Adyghe State University, Maikop

\begin{abstract}
The article discusses the features of diversification as a tool for development in the regions of the North Caucasus by the example of the Republic of Adygea. Particular attention is paid to the activation of processes of diversification in rural areas of the Republic of Adygea.

Keywords: diversification, balanced development, the Republic and the North Caucasus, potential, strategy
\end{abstract}

В современной высококонкурентной среде проблема устойчивого и сбалансированного развития российских регионов по-прежнему остается весьма актуальной, что получило свое подтверждение в ходе прохождения ими активной фазы текущего финансово-эконом ического кризиса. В разрабатываемых региональных стратегиях, хотя и отражена необходимость устойчивого и сбалансированного развития, тем не менее, они формируются без учета структурных особенностей региональной экономики, потенщиала развития и динамических характеристик внешней среды.

В экономике большинства субъектов Российской Федерации наряду с неустойчивостью региональной динамики имеют место значительные диспропорции, влияющая негативно, как на эффективность функционирова- ния региональной экономики, так и на социальное благополучие проживающего в них населения. В то же время, органы региональной власти не относят указанное явление к разряду доминирующих проблем. Между тем, магистральным направлением обеспечения устойчивого развития и структурной сбалансированности экономики регионов, преодоления социально-экономических различий территорий является их саморазвитие с использованием возможностей различных инструментов, одним из которых является диверсификация экономики.

Диверсификация экономики региона представляет собой непрерывный процесс, направленный как на обеспечение текущих конкурентных преимуществ, так и на формирование стратегической устойчивости и сбалансированности социально-экономического 
развития региона. Диверсификация позволяет обеспечить такие условия для деятельности экономики, которые формируют инвестиционную и социальную привлекательность региона для бизнеса и населения и, как следствие, обеспечивают динамичное развитие и структурную сбалансированность.

Процесс диверсификации является откликом экономической системы на существующие или прогнозные изменения в ситуациях, вызывающих возмущения в региональ но й экономической системе и влияющих на показатели ее функцио нирования.

Следует отметить, что идея диверсификации имеет многолетнюю историю. Она, прежде чем приобрела современные черты, в рамках глобальной стратегии фирм прошла сложный путь развития, меняясь под влиянием внешних обстоятельств, так и внутрифирменных критериев.

Характер диверсификации определяется социально-экономическими особенностями страны и ее регионов. Вместе с тем на ее развитие влияют и некоторые общие факторы (относящиеся ко всем странам): научно-техническая революция, борьба за высокие прибыли, необходимость изыскивать сферы для приложения своих накоплений, милитаризация экономики, конкурентная борьба, боязнь отстать от технического прогресса.

Преимущества диверсифицированного предприятия заключаются так же в возможности объединения усилий для достижения единых целей. Успешный результат такого объединения обуславливается действием синергетического эффекта, т.е. когда целое представляет собой нечто большее, нежели сумму частей. Так, некоторые крупные корпорации повышают прибыльность своих вновь приобретенных компаний путем совершенствования на них систем руководства и финансового контроля, а также путем реорганизации этих компаний на специализированные по видам деятельности подразделения. В этом случае положительный результат дает совместное использование ресурсов и опыта. Наибольшее значение синергетический эффект имеет место в случае, если подразделения находятся в родственных отраслях.

Основной целью диверсификации в регионе является обеспечение стабильности региональной экономики. Это достигается посредством выполнения основных задач диверсификации, таких как создание новых рабочих мест, сокращение производственных издержек и развитие малого и среднего бизнеса. Но в то же время при диверсификации всей экономики, важное место отводится решению задач, которые необходимо решить на уровне конкретных отраслей и регионов.

Диверсификация экономики особенно важна для проблемных регионов, в том числе и для Республики Адыгея. Она позволяет преодолевать монополизм предприятий-гиг антов, который отрицательно сказывается на общем состоянии их экономики.

К сожалению, в Стратегии социально-экономического развития Республики Адыгея на период до 2020 года проблемы и перспектив ы диверсификации экономики региона не получили должного отражения, а само слово «диверсификация» в объемистом документе упоминается лишь единожды.

Между тем, на современном этапе развития российских регионов диверсификация экономики выступает одной из приоритетных задач, причем само понятие диверсификации на региональном уровне приобретает все большую актуальность и трансформируется в качественно новую категорию, представленную комплексом многофункциональных механизмов, обеспечивающих реальный эффект от их реализации [1].

Диверсификация региональной экономики предполагает проведение активной политики 
региональных властей по изменению структуры экономики, ее совершенствованию на основе стимулирования, в том числе финансового, отдельных отраслей и предприятий. В диверсификации структуры экономики исключительная роль отводится стимулированию и поддержке частной предпринимательской инициативы, поскольку предприятия бизнеса несут в себе огромный инновацио нный потенциал, способствуя созданию новых рабочих мест и снижению безработицы, что, в свою очередь, ведет к смягчению социально й напряженности. Региональные власти должны проявлять особую заботу о динамичном развитии контрактных отношений между крупным и малым бизнесом, обеспечивающим достижение синергетического эффекта от совместной деятельности [2].

Региональные власти, содействуя процессам диверсификации, могут оказывать прямую финансово-имущественную, кадровую и прочую поддержку, участвовать в финансовохозяйственной деятельности в качестве самостоятельного рыночного игрока, а также воздействовать на указанные процессы косвенно, создавая и стимулируя негосударственные институты диверсификации экономики - гарантийные фонды, технопарки, особые экономические зоны и т.п.

Динамика ситуации в экономике Республики Адыгея за последние годы, особенно в ее периферийных муниципальных образованиях, позволяет судить об усилении в ней процессов диверсификации. Введен в действие и успешно функционирует в указанном локалитете первый в регионе свинокомплекс ЗАО «Киево-Жураки» с использованием современных канадских технологий выращивания. Компания «Атомэнергомаш» с дочерними предприятиями приступила к проектированию строительства ветропарков с суммарной установленной мощьностью 750 МВТ на наиболее подходящих по ветровым нагрузкам территориях Гиагинского, Шовгеновского и Кошехабльского районов, входящих в зону Армавирско-Гиагинского ветрового коридора. Ожидаемые налоговые поступления в региональный бюджет от функционирования совместного предприятия составят порядка 150 млн. руб. в год.

В субрегиональном кластере торговотранспортно-логистического типа, охватывающем периферийные муниципальные образования Адыгейск, Тахтамукайский и Теучежский районы, начато строительство нефтеперерабатывающего завода, стоимостью в 30 млрд. рублей, что позволит создать 1,5 тыс. новых рабочих мест и еще дополнительно порядка 400 рабочих мест в сфере малого и среднего бизнеса.

Новый импульс развитию малого и среднего бизнеса в субрегиональном локалитете туристско-рекреационного типа придаст вхождение Республики Адыгея в создаваемый на Юге России туристический кластер.

Как видно из практики производственнохозяйственных процессов в регионах Юга России, одним из способов диверсификацио нных изменений региональной экономики является развитие ее кластерной организации. Кластер, как форма организации производства в экономике региона, изначально предполагает самостоятельность, стихийность и спонтанность создания, что вытекает из самого термина. Однако определенная степень управляемости при создании, развитии и функционировании кластера существует и требует своего методического обеспечения [3].

При формировании кластеров с учетом спроса и предложения экономических субъектов проводится оценка потенциала региона с точки зрения соблюдения интересов участников экономической политики. Кластер необ- 
ходимо рассматривать как одну из интеграционных форм организации производства в экономике региона, основанную на балансе интересов, как его участников, так и других субъектов социально-экономической системы.
Поэтому кластеры являются перспектив но й формой организации производства, обеспечивающей высокий мультипликативный эффект.

\section{ЛИТЕРАТУРА}

1. Стратегия социально-экономического развития Республики Адыгея до 2025 года// Майкоп 20 марта 2008 года - Закон Республики Адыгея № 327 - Р3.

2. Конкурентоспособность регионов: Теоретико-прикладные аспекты. Под редакцией Ю. Перского, М. Колюжного - М.: ТЕИС, 2003 - 472с.

3. Тамов, А.А. Теоретико-методологические аспекты исследования межрегиональной социально-экономической дифференциации в пространстве макрорегиона / А.А. Тамов,

А.Г. Добровольский // Вестник Адыгейского государственного университета. Сер. 5, Экономика. - Майкоп: Изд-во АГУ, 2013. Вып. 2 (115). - С. 71 -76.

4. Мокрушин, А.А., Корпоративное управление интеграционными трансакциями в АПК региона: функциональные особенности, критерии эффективности / А.А. Мокрушин, С.В. Кесян // Новые технологии, 2013. №4. - С. 61-67. 


\title{
ИМИДЖ МУНИЦИПАЛЬНОГО ОБРАЗОВАНИЯ, КАК ОДИН ИЗ КЛЮЧЕВЫХ АСПЕКТОВ НА ПУТИ К ЭКОНОМИЧЕСКОМУ РАЗВИТИЮ РЕГИОНА
}

Услистый В.И.

Студент 1 курса магистратуры, Адыгейский государственный университет, г. Майкоп

Научный руководитель: Хатукай С.A.

к.э.н., доцент, Адыгейский государственньий университет, г. Майкоп

\begin{abstract}
Аннотация. В данной статье проведен анализ имиджа муниципального образования «Город Майкоп». Раскрыты проблемы, и пути их решения, в формировании положительного имиджа города.

Ключевые слова: Имидж, муниципальное образование, Маркетинг территорий, бренд, репутация города, качество жизни населения.
\end{abstract}

\section{RESEARCH IMAGE MUNICIPALITIES AND WAYS OF ITS DEVELOPMENT, BY THE EXAMPLE OF MAIKOP}

Uslisty $V . I$. student 1 course magistracy, Adygei state university, Maikop Research supervisor: Khatukay S.A. Cand.Econ.Sci., associate professor, Adygei state university, Maikop

\begin{abstract}
This article analyzes the image of the municipality "City of Maikop". Solved problems and their solutions, in the formation of a positive image of the city.

Keywords: Image, municipality, Marketing areas, brand, reputation of the city, the quality of life.
\end{abstract}

Имидж региона - это его стереотипизированный образ в массовом сознании. В этом образе слить представления людей по поводу социокультурных, исторических, социально-экономических, политических и других особенностей данной территории.

При этом субъективное представление каждого человека о регионе может складываться как на основе конкретных личных впечатлений, так и опосредованным образом, из материалов масс-медиа, литературных и кинематографических источников, на основе рассказов очевидцев, слухов и домыслов. Таким образом, имидж региона имеет многослойную структуру - образ одного и того же региона в сознании разных людей может серьезно различаться.

Но имиджем региона можно и нужно управлять. Многие эксперты полагают, что именно культура может стать реальным локомотивом развития российских городов и территорий. Российские города обладают колоссальным неиспользованным символическим капиталом культуры . И не всегда городские власти понимают: культура обладает таким потенциалом, который фактически по долговременности и значимости перевешивает потенциал собственно индустриального или торгового секторов экономики.

Мировой опыт показывает, что культура в виде культурных проектов и сценариев развития может вывести депрессивные территории и города на новый уровень развития. Широко известен опыт испанской Барселоны, которая за двадцать лет из грязного, задымленного промышленного центра превратилась в чистый, открытый культурный город мирового значения. Программа ребрендинга Барселоны была основана на активизации культурных и экологических факторов: демонтаж морально и технически устаревшей промышленно й зоны, вывод промышленных предприятий за черту города, регулярное проведение 
музыкальных и театральных фестивалей, реставрация памятников, организация Олимпиады, привлечение

туристо в.

Следствием этой культурной и экологической имиджевой программы стала капитализация территории, приток новых капиталов и людей, привлеченных новым имиджем города.

По этому актуальность развития имиджа муниципальных образований, на территории Российской федерации не поддается сомнениям, безусловно, это долгий и трудоемкий процесс, но результаты превосходят, все ожидания.

Основой для формирования имиджа, бренда и репутации города является территориаль ная индивидуальность. Это, во-первых, его официальные, "опознавательные" характеристики, своеобразный "паспорт" территории (место на карте, государственная и субфедеральная принадлежность, название, герб, флаг и т.д.). Во-вторых, территориальная индивидуальность включает в себя совокупность особенностей и ресурсов города. Это природные, демографические, исторические, социальные и культурные особенности и ресурсы; экономические особенности и ресурсы; организацио нно-правовые, а также информацио нные особенности и ресурсы; в-третьих, выделяются технологии и подходы к работе, доверие партнеров и экспертная информация, уровень и качество руководства, особенности общения и многое другое. На базе территориальной индивидуальности формируются имидж, бренд и репутация города

Основными, являются, следующие параметры, определяющие имидж города:

- качество жизни - наличие жилья для различных социальных групп населения, социальные услуги, качество продуктов питания, сооружения для отдыха, уровень и доступность образования, лечения;

- кадровые ресурсы - подготовка, повышение квалификации, адаптация к новым условиям и требованиям;

- инфраструктура - транспорт, связь, средства передачи данных, гостиницы, бытовые услуги и пр.;

- высокие технологии - способность территории развивать и поддерживать высокотехнологичные виды экономической деятельности, обновлять существующую базу;

- капитал - мaсca капитала, сконцентрированная на территории в виде собственных и привлеченных средств;

- контролирующие органы - рациональность, мобильность, эффективность, честность, отсутствие бюрократизма;

- инфраструктура бизнеса - доступность и уровень услуг в области консалтинга, аудита, рекламы, права, информации, публичные отношения, институциональные условия осуществления сделок с титулам и собственности;

- власть - команда личностей, компетентность членов команды, нестандартность идей, стиль принятия решений, прозрачность законотворчества, отношение к социальным проблемам.

Bce представленные параметры в той или иной степени влияют на формирование благоприятного имиджа Муниципального образования, а в перспективе и на имидж региона.

Исходя из перечисленных выше параметров, мы провели анализ имиджа города Майкопа, и вывели следующие выводы.

С точки зрения стоимости жизни в городе, Майкоп довольно привлекателен, сравнительно дешевое жилье, в сравнении с г. Краснодаром. Низкие цены на продукты первой необходимости. Но в тоже время, недостаток рабочих мест и низкая заработная плата, снижают его привлекательность.

По возможНОсти

удовлетворения потребностей населения, Майкоп уступает 
некоторым своим соседям, к примеру, городу Краснодару, это заключается в менее развитой инфраструктуре, в меньшем количестве учебных заведений, и меньшем количестве рабочих мест. Так же у города есть связь с прошлым, большое количество памятных досок, памятников, и архитектурных шедевров, которые необходимо сохранять для следующих поколений. Реконструкция зданий относящихся к исторической ценности, позволит развить имидж исторического города, что в свою очередь привлечет инвесторов, для реконструкции таких зданий, улучшения инфраструктуры в городе, и как следствие развития туристического кластера.

В Майкопе, как столице Республики Адыгея, сосредоточены основные Промышленность и Культурное наследие всей Адыгеи. Таким образом, это создает имидж города Майкопа как промышленной и культурной столицы республики. В тоже время, можно утверждать, что наш город не лишен и туристического кластера, хотя и слабо развитого из-за отсутствия финанс ирования.

Безусловно, не обойдется и без определенных проблем, основными проблемами формирования имиджа города, по нашему мнению являются:

1. Отсутствие единого понятия «Имидж».

2. Отсутствие четкой, понятной грамотной информационной конщепщии образа муниципального образования.

3. Не заинтересованность населения в получении актуальной информации. (Социальные сети, Газеты, Телевидение, Радио.)

4. Низкий уровень правосознания населения.

5. Незнание населением своих прав и обязанностей

В первую очередь необходимо заинтересовать в развитии имиджа города самих жителей, тогда в будущем оглядываясь на их желания, местная власть будет принимать необходимые для этого решения. Развитие молодежной политики, привлечение молодых специалистов на государственную службу, и в другие сферы развития нашего города, позволит привнести свежие идеи и дух новаторства в развитие города. Многие идеи молодых жителей нашего города, лишены необходимого внимания, и считаются либо очень дорогими, либо не существенными, не смотря на то, что возможно именно реализация данных идей, даст необходимый толчок нашему городу к развитию, что в свою очередь позволит городу заработать репутацию, и стать известным в России.

\section{ЛИТЕРАТУРА}

1. Ирина Важенина ИЭ УрО РАН Advertology.Ru «Имидж, бренд и репутация города» [Электронный ресурс]. - Режим доступа: http://www.repcom.ru/content/view/113/83/.

2. Соколова Н.Г. Качество жизни населения города в маркетинге территории монография. - Электрон. текстовые данные. - Саарбрюккен: LAP LAMBERT Academic Publishing, 2013. - 324 c. [Электронный ресурс]. - Режим доступа: http://www.iprbookshop.ru/54501. 


\title{
ТЕНДЕНЦИИ ФОРМИРОВАНИЯ ВНУТРИРЕГИОНАЛЬНЫХ СОЦИАЛЬНО- ЭКОНОМИЧЕСКИХ РАЗЛИЧИЙ
}

Устова Г.М.

Магистрант II курса, Адыгейский государственный университет, г. Майкоп

Научный руководитель: Пииканокова Н.И.

к.э.н., профессор, Адыгейский государственный университет, г. Майкоп

\begin{abstract}
Аннотация. В статье рассматриваются тенденции формирования внутрирегиональных различий в Республике Адыгея за последние годы. Особое внимание уделено причинам, вызвавиим углубление или уменьшение этих различий в различных сферах.

Ключевые слова: Республика Адыгея, регион, внутрирегиональные социально-экономические различия, территории, ресурсы, уровень жизни, миграция, принципь, стратегия.
\end{abstract}

\section{TRENDS SHAPING INTRAREGIONAL SOCIOECONOMIC DIFFERENCES}

Ustova G.M.

Undergraduate of 2 courses, Adyghe State University, Maikop

Supervisor: Pshikanokova N.I.

Ph.D., professor, Adyghe State University, Maikop

\begin{abstract}
This article examines trends in the formation of intra-regional differences in the Republic of Adygea in recent years. Particular attention is paid to the reasons that caused the deepening or reduction of these differences in the various fields.

Keywords: Republic of Adygea, the region, intra-regional socio-economic differences, territory, resources, quality of life, migration, principles, strategy.
\end{abstract}

В современных кризисных условиях для бюджетно-дефицитных регионов Юга России характерна значительная социально экономическая неоднородность, влияющая негативно на эффективно сть функционирования и развития региональной экономики и, соответственно, на социальное благополучие проживающего населения. Однако, как показывает практика, органы региональной власти не относят указанное явление к разряду ключевых проблем. Со своей стороны, внутрирегиональ ная социально-эко ном ическая дифференциация является весьма чувствительным сегментом в сфере обеспечения социально-политической стабильности в регионе. Нерешенность проблем в этом сегменте негативно сказывается и на эффективности регионально й экономики.

Из всевозможных внутрирегио нально й проявлений социально экономической неоднородности наибольшего внимания заслуживают различия, которые образуют:
- муниципальные образования, входящие в состав одного региона;

- экономико-географические районы, которые выделяются в границах отдельно взятого региона страны;

- отдельные групाы муниципаль ны х образований;

- региональный центр и остальные муниципальные образования региона.

В совокупности аспектов, которые характеризуют

межмуниципаль ную социально-эко номическую неоднородность, заслуживает большего внимания, на наш взгляд, сравнительно-эволюционный анализ различий, охватывающих основные показатели уровня жизни населения, бюджетоформирующие возможности муниципальных образований и ситуация в сфере занятости населения. Указанные аспекты в наибольшей мере характеризуют то, как реализуются региональные интересы на межмуниципальном уровне [1].

Следует отметить, что при определении системы характеризующих уровень жизни 
населения региона показателей, среди специалистов имеют место существенные различия в подходах и позициях. Однако преобладающая их часть придерживае тся того мнения, что многочисленные показатели уровня жизни населения можно свести к трем группам:

- потреблению основных видов продовольствия;

«денежным»

показателям, характеризующим уровень жизни населения; - обеспеченности жильем и предметами длительного пользования.

Последняя группа показателей формируется под определяющим влиянием денежных доходов населения, что позволяет эту группу углубленно не рассматривать.

В проведенных за последние годы в исследованиях по проблематике внутрирегио нальных социально экономических различий, как было указано выше, выявлено, что указанные различия, имеющиеся между региональными центрам и и остальной территорией субъекта федерации, как правило, качественно более глубокие, чем различия между самими муниципальными образованиями [2].

Республика Адыгея в указанном смысле не является исключением, поэтому при анализе тенденций межмуниципальной социально экономической неоднородности разрез «Майкоп - остальные муниципалитеты региона» представляет наибольший исследовательский интерес.

За последнее десятилетие на фоне общего ухудшения социально-эко номичес ко го положения в стране, равно как и в большинстве регионов, произошло определенное сокращение межмуниципальной неоднородности в разрезе «Майкоп - остальные муниципалитеты региона» (табл. 1).

\section{Таблица 1 - Динамика удельного веса Майкопа и остальных муниципальных образований в основных показателях социально-экономического развития Республики Адыгея в 2004 -2014 г2., \%.}

\begin{tabular}{|l|c|c|c|c|}
\hline \multirow{2}{*}{} & \multicolumn{2}{|c|}{ Майкоп } & \multicolumn{2}{c|}{ Остальные МО } \\
\cline { 2 - 5 } & 2004 & 2014 & 2004 & 2014 \\
\hline Среднегодовая численность занятых & 48,5 & 48,7 & 51,5 & 51,3 \\
\hline Денежные доходы населения & 49,1 & 48,7 & 50,9 & 51,3 \\
\hline Розничный товарооборот & 51,8 & 46,6 & 48,2 & 53,8 \\
\hline Объем платных услуг & 67,5 & 70,0 & 32,5 & 30,0 \\
\hline Строительство жилья & 38,4 & 36,2 & 61,6 & 63,8 \\
\hline Платежи в бюджет РА & 50,2 & 51,7 & 49,8 & 48,3 \\
\hline
\end{tabular}

В целом резервы дальнейшего роста производства в большинстве крупных и средних предприятиях как Майкопа, так и сельских районов с использованием действующих мощностей исчерпаны.

Исключительно важной составляющей системы показателей, внутрирегио нальную определяющей социально экономическую неоднородность, являются различия в потреблении продуктов питания. Потребность населения в продовольствии, определяемая физиологическими нормами душевого потребления, зависит от различных факторов, прежде всего, от демографической структуры населения, характера трудовой деятельности, климатических условий, национальных традиций и пр. [3].

В последнее десятилетие произошло заметное улучшение качественных характеристик рациона как городских, так и сельских жителей, что выражается, в частности, в увеличении в рационе таких продуктов, как мясо и мясопродукты, овощи и фрукты. Увеличение потребления таких продуктов, как хлебобулочные изделия и картофель можно объяснить тем, что в уровне потребления население Адыгеи еще не достигло количественного насыщения. В 
целом, за последнее десятилетие, горожане Адыгеи стали было питаться лучше, имея сопоставимый по качеству рацион с сельскими жителями, однако за последние три-четыре года рацион городских жителей стал из-за текущего кризиса вновь ухудшаться.

Для Республики Адыгея, как и для большинства бюджетно-дефицит ны х регионов Юга России характерна ситуация, когда преобладающая часть местного населения расходует на приобретение потребительских товаров и услуг почти все денежные поступления. Следует еще отметить, что значительная часть населения мунищипальных образований Республики Адыгея, территории которых непосредственно примыкают к Краснодару, предпочитает отвариваться в краевом центре. Это одна из причин того, что свыше $2 \backslash 3$ денежных средств, которые вводятся в оборот в Адыгее, вывозится за ее пределы.

\section{ЛИТЕРАТУРА}

1. Гершкович, Б.Я. Необходимость смягчения асимметрии экономического и социального развития Юга России // Экономика развития региона: проблемы, поиски, перспективы: Ежегодник. Вып.2. - Волгоград: Изд-во ВолГУ, 2012. - С. 388-389.

2. Тамов, А.А. Теоретико-методологические аспекты исследования межрегиональной социально-экономической дифференциации в пространстве макрорегиона / А.А. Тамов, А.Г. Добровольский // Вестник Адыгейского государственного университета. Сер. 5, Экономика. - Майкоп: Изд-во АГУ, 2013. Вып. 2(115). - С. 71-76.

3. Тургель И.Д. Локальная асимметрия регионального развития: содержание, оценка, социально-экономические последствия. http://ec socman.edu.ru/data/771/668/1219/012_Turgel_I.pdf ]. 


\title{
ИНВЕСТИЦИОННАЯ ПРИВЛЕКАТЕЛЬНОСТЬ МУНИЦИПАЛЬНОГО ОБРАЗОВАНИЯ «ГОРОД МАЙКОП» И МЕРЫ, ПРИНИМАЕМЫЕ ДЛЯ ЕЕ ПОВЫШЕНИЯ.
}

Хамуков А. $A$. Студент 2 курса магистратуры, Адыгейский государственный университет, г. Майкоп Научный руководитель: Тамов А. $А$. д.э.н., профессор, Адыгейский государственный университет, г. Майкоп

\begin{abstract}
Аннотация. В данной статье анализируется инвестиционной привлекательность мунициипального образования «Город Майкоп», а так же основные мероприятия по ее улучшению.

Ключевые слова: инвестиционная привлекательность, инвестиционный потенцииал, инвестиционный риск, факторы инвестиционной привлекательности.
\end{abstract}

\section{INVESTMENT ATTRACTIVENESS OF THE MUNICIPALITY «CITY OF MAIKOP» AND THE WAYS OF THE MEASURES TAKEN TO IMPROVE IT.}

Khamukov A.A. student of 2 course of magistracy, Adygei state university, Maikop Research supervisor: Tamov A.A. Doct.Econ.Sci., professor, Adygh state university, Maikop

\begin{abstract}
This article analyzes the investment attractiveness of the municipality "City of Maikop" and basic measures for its improvement.

Key words: investment attractiveness, investment potential, investment risk, investment attractiveness factors.
\end{abstract}

В социально-экономическом развитии муниципальных образований Российской Федерации важнейшую роль играют инвестиционные процессы, проходящие на их территории. В последнее время большую актуальность приобрела проблема создания эффективной системы управления инвестиционной активностью территории, как важнейшей составной части действующего инвестиционного процесса.

Муниципальное образование «Город Майкоп〉 является столицей Республики Адыгея, а также его административным и культурным центром Республики Адыгея. Майкоп можно назвать и промышленно й столицей республики. Ведь именно здесь сосредоточено $60 \%$ всего промышленного потенциала Адыгеи. Основными отраслями являются пищевая, деревообрабатывающая, целлюлозно-бумажная, машиностро итель ная промышленность.

Сейчас в городе стабильно работают крупные предприятия, среди которых наиболее известны ОАО «Редукторный завод «ЗАРЕМ», ОАО «Майкопс к ий машиностроительный उавод», $3 А О$ «Картонтара». В черте города, на реке Белой расположена Майкопская ГЭС. На сегодняшний день территория Майкопа с пригородной зоной составляет 28,2 тыс. кв. метров. В состав муниципального образования входят 8 населенных пунктов: ст. Ханская, х. Гавердовский, х. Веселый, пос. Родниковый, пос. Северный, пос. Подгорный, х.Косинов, пос. Западный.

Сегодня Майкоп - крупный экономический и культурный центр, хорошо известный в регионе, на Юге России, в Российской Федерации.

Майкоп обладает наиболее мощным предпринимательским потенциалом среди всех муниципальных образований Республики Адыгея в силу исторически сложившихся условий. Этому способствует наличие трудовых, финансовых ресурсов, рынков сбыта, статус столичного 
административного центра региона.

Экономика города представляет собой многоотраслевое хозяйство и включает 13 основных видов деятельности. На долю 8 базовых отраслей экономики приходится
96,2\% всего оборота, основными из которых являются промышленное производство и торговля.

\section{Таблица 1 - Оборот по видам экономической деятельности по крупным} и средним организациям муниципального образования "Город Майкоп" за 2015 год, млн. руб.

\begin{tabular}{|c|c|c|c|c|c|c|}
\hline $\begin{array}{c}\text { № } \\
\Pi / \Pi\end{array}$ & ОКВЭД & $\begin{array}{l}\text { Количество } \\
\text { организаций }\end{array}$ & $\begin{array}{c}\text { Объем за } \\
\text { 2015г., млн. } \\
\text { руб. }\end{array}$ & $\begin{array}{c}\text { Объем за } \\
2014 \text {., млн. } \\
\text { руб. }\end{array}$ & $\begin{array}{c}\text { Темп роста } \\
\text { 2015г. к } \\
2011 \Gamma . \\
\%\end{array}$ & $\begin{array}{c}\text { Уд.вес } \\
\text { раздела в } \\
\text { общем } \\
\text { обороте } \\
\text { за 2015г., } \\
\%\end{array}$ \\
\hline & $\begin{array}{l}\text { Республика Адыгея - } \\
\text { ВСЕГО }\end{array}$ & 382 & 89921,7 & 77214,7 & 116,5 & \\
\hline & Майкоп - ВСЕГО & 179 & 32473,8 & 31302,8 & 103,7 & 100,0 \\
\hline 1. & $\begin{array}{l}\text { Оптовая и розничная } \\
\text { торговля; }\end{array}$ & 30 & 12142,1 & 10440,4 & 116,3 & 37,4 \\
\hline 2. & $\begin{array}{l}\text { Производство и } \\
\text { распределение } \\
\text { электроэнергии }\end{array}$ & 10 & 6714,9 & 6438,8 & 104,3 & 20,7 \\
\hline 3. & $\begin{array}{l}\text { Обрабатывающие } \\
\text { производства }\end{array}$ & 21 & 6326,8 & 6798,9 & 93,1 & 19,5 \\
\hline 4. & Транспорт и связь & 24 & 3671,9 & 3342,1 & 109,9 & 11,3 \\
\hline 5. & $\begin{array}{l}\text { Сельское хозяйство, } \\
\text { охота и лесное хозяйство }\end{array}$ & 10 & 1684,5 & 2080,3 & 81 & 5,2 \\
\hline 6. & Строительство & 2 & 494,1 & 530,2 & 93,2 & 1,5 \\
\hline 7. & $\begin{array}{l}\text { Добыча полезных } \\
\text { ископаемых }\end{array}$ & 2 & 354,1 & 558,0 & 63,5 & 1,1 \\
\hline 8. & $\begin{array}{l}\text { Операции с недвижимым } \\
\text { имуществом }\end{array}$ & 24 & 344,3 & 386,8 & 89 & 1,1 \\
\hline 9. & Образование & 19 & 318,2 & 307,4 & 103,5 & 1,0 \\
\hline 10 & $\begin{array}{l}\text { Здравоохранение и } \\
\text { предоставление } \\
\text { социальных услуг }\end{array}$ & 5 & 195,3 & 196,5 & 99,4 & 0,6 \\
\hline 11 & $\begin{array}{l}\text { Государственное } \\
\text { управление }\end{array}$ & 5 & 118,2 & 94,5 & 125 & 0,4 \\
\hline 12 & $\begin{array}{l}\text { Предоставление прочих } \\
\text { коммунальных услуг }\end{array}$ & 20 & 83,5 & 106,1 & 78,7 & 0,3 \\
\hline 13 & Гостиницы и рестораны & 7 & 25,3 & 22,7 & 111,5 & 0,1 \\
\hline
\end{tabular}

Удельный вес муниципального образования «Город Майкоп» в общем обороте Республики Адыгея составляет $36,1 \%$. По сравнению с 2014 годом этот показатель снизился на 4,4 процентных пункта.

По данным Госкомстата по РА в Майкопе зарегистрировано более 4,1 тыс. (4136) предприятий, организаций, их филиалов и других обособленных подразделений, что составляет $49,5 \%$ от общего количества субъектов по РА. Из них занято в рыночных отраслях $88,6 \%$ или 3664 субъектов, что свидетельствует о значительно м экономическом потенциале и преобладании экономики над социальной сферой.

В экономику и социальную сферу города за период 2011 - 2015 годы направлялись инвестиции из бюджетов всех уровней, 
средства предприятий и организаций, финансирования за 2011-2015 годы составил индивидуальных предпринимателей и 26,0 млрд. руб.

средства граждан.

Для сравнения объемов инвестиций возьмем

Объем инвестиций в основной капитал в столицы республик, входящих в Северомуниципальном образовании «Город Кавказский Федеральный округ [3].

Майкоп〉 за счет всех источников

Таблица 2 - Объем инвестиций в муниципальном образовании «Город Майкоп» за период $2011-2015$ года, млн. руб.

\begin{tabular}{|l|l|l|l|l|l|}
\hline & 2011 г. & 2012 г. & 2013 г. & 2014 г. & 2015 г. \\
\hline $\begin{array}{l}\text { Объем инвестиций за счет всех } \\
\text { источников финанс ирования, млн. } \\
\text { руб. }\end{array}$ & 4703,9 & 4260,4 & 5014,0 & 6208,8 & 7828,7 \\
\hline
\end{tabular}

\section{Сравнение объемов инвестиций в города СКФО и МО "Город Майкоп"}

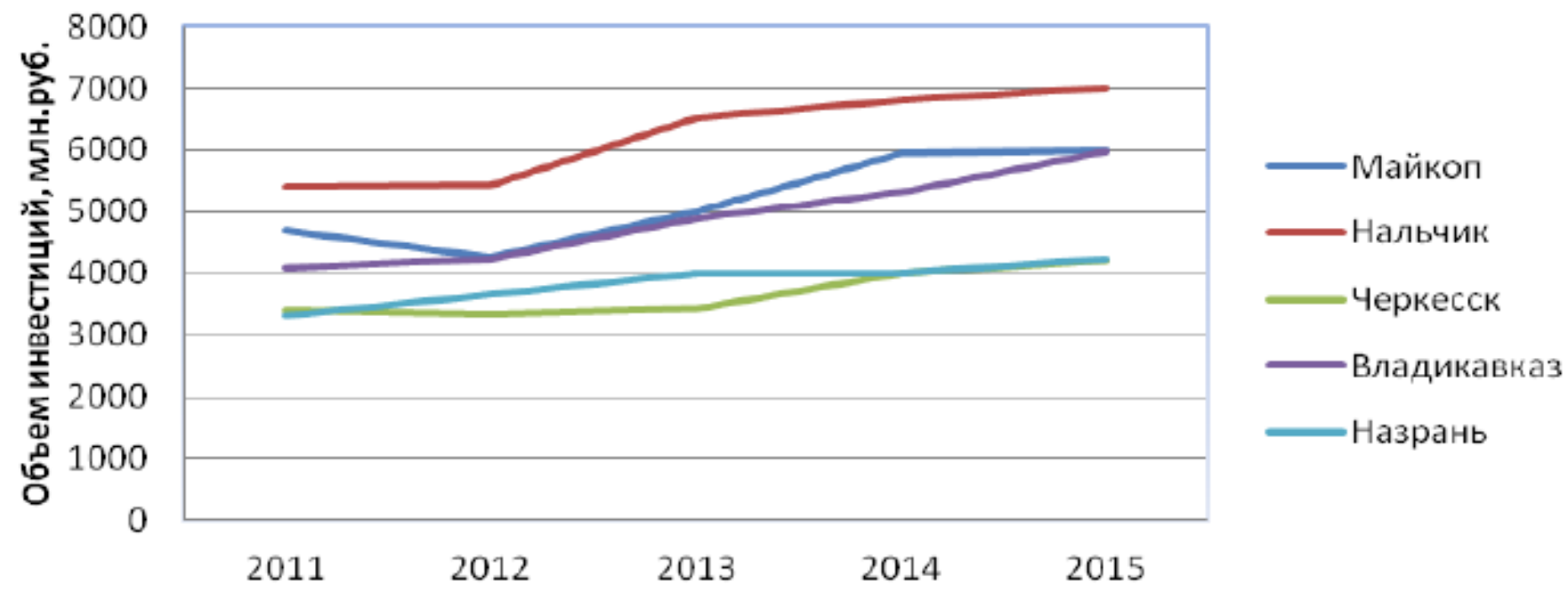

Рисунок 1. «Сравнение объема инвестиций в города СКФО и МО «Город Майкоп»

Как видно из диаграммы, объемы инвестиций в МО «Город Майкоп» в абсолютном выражении за весь период уступают лишь вложениям в МО «Город Нальчик».

Однако поступательное увеличение объема инвестиций не в полной мере отображает ситуацию в муниципальном образовании.

Так, например:

1. Существующий объем инвестиций не обеспечивает восполнение выбывающих и морально устаревших основных фондов.

2. Более половины источников инвестиций в основной капитал по-прежнему остаются собственными средствами предприятий (прибыль, амортизационные отчисления);
3. Высокий удельный вес инвестиций в основной капитал, финансируемых за счет бюджетных средств на фоне невысокой инвестиционной активности.

Дефицит инвестиционных ресурсов создает серьезные ограничения для устойчивости развития и занятия муниципаль ным образованием «Город Майкоп» лидирующих позиций в регионе.

Приоритетным направлением развития муниципального образования «Город Майкоп» на 2016-2018 годы является создание благоприятного инвестиционного климата для обеспечения устойчивого социоэколого-экономического развития города и повышения качества жизни населения. 
Основные направления развития, задачи, программные мероприятия и объемы финансирования проектов разработаны согласно Инвестиционной стратегии муниципального образования «Город Майкоп〉 на 2013-2020 годы. В перечень также включены мероприятия по строительству и реконструкции объектов федерального и республиканского значения, расположенных на территории муниципального образования «Город Майкоп».

Bce мероприятия по улучшению инвестиционной привлекательности будут проводиться по трем ключевым направле ниям:

\section{1. Повымение}

качества

\section{институичональной}

средbl

$u$ эффективности управления.

Данное направление призвано решать такие задачи, как:

- Определение вектора позиционирования муниципального образования «Город Майкоп〉 в регионе, стране и мире.

- Разработка и реализация комплексной программы формирования и поддержки имиджа (бренда) муниципального образования «Город Майкоп».

- Активизация деятельности ПО продвижению имиджа муниципального образования «Город Майкоп».

- Повышение информационной открытости инвестицио нного процесса.

- Снижение административных барьеров для инвесторов.

- Совершенствование нормативны х правовых актов, регламентирующих инвестицио нную деятельность в г. Майкоп, с целью снижения инвестицио нных рисков.

- Регламентация системы управления реализацией Инвестиционной стратегии.

- Развитие государственно-частного партнерства.

2. Создание эффективных механизмов привлечения инвестищий в экономику муниципального образования «Город Майкоп».

В рамках данного направления будут решаться следующие задачи:

- Повышение

результативност и использования и совершенствования механизмов стимулиров ания инвестицио нно й активно ст и хозяйствующих субъектов.

- Содействие взаимодействию хозяйствующих субъектов инвестиционной сфере.

- Реализация инвестиционных проектов на территории муниципального образования «Город Майкоп».

- Привлечение участников и инструментов финансового рынка для решения задач роста инвестиций в экономику и социальную сферу города.

- Совершенствование нормативно й законодательной базы с учетом специфики деятельности субъектов малого и среднего предпринимательства (МСП).

- Повышение информационной открытости принятия решений государственных органов для предпринимателей.

- Совершенствование взаимоотношений муниципальных служащих с субъектами МСП, развитие инфраструктуры поддержки МСП.

- Поддержка местных производителей товаров и услуг.

3. Повымение качества городского пространства.

- Повышение доступности жилья.

- Строительство объектов социальной сферы.

- Привлечение инвестиций в жилищнокоммунальное хозяйство.

- Развитие улично-дорожной системы города.

На реализацию указанных задач направле на 
муниципальная программа «Формирование Майкоп» на 2016-2018 годы».

благоприятной

муниципального

$$
\text { инвестицио нной }
$$

образования среды

«Город

\section{Прогнозируемые результаты}

Прогнозируемые результаты выполнения

Таблица 3 - Целевые показатели эффективности реализации

Программы «Формирование благоприятной инвестиционной среды

мунициального образования "Город Майкоп» на 2016-2018 годы»

\begin{tabular}{|c|c|c|c|c|c|c|c|c|}
\hline \multirow{2}{*}{$\begin{array}{c}\text { № } \\
\text { П/ }\end{array}$} & \multirow{2}{*}{$\begin{array}{c}\text { Наименование } \\
\text { программы, } \\
\text { наименование } \\
\text { показателя }\end{array}$} & \multirow{2}{*}{$\begin{array}{c}\text { Источник } \\
\text { получения } \\
\text { информации }\end{array}$} & \multirow{2}{*}{$\begin{array}{l}\text { Ед. } \\
\text { изМ. }\end{array}$} & \multicolumn{5}{|c|}{$\begin{array}{c}\text { Значения показателей } \\
\text { эффективности }\end{array}$} \\
\hline & & & & 2015 & 2016 & 2017 & 2018 & $\begin{array}{c}\text { Итого } \\
\text { 3a } 2016- \\
2018 \text { гг. }\end{array}$ \\
\hline 1. & $\begin{array}{l}\text { Инвестиции } \\
\text { основной капитал за } \\
\text { счет всех источников } \\
\text { финансирования }\end{array}$ & $\begin{array}{l}\text { Прогноз социально- } \\
\text { экономического } \\
\text { развития } \\
\text { муниципального } \\
\text { образования «Город } \\
\text { Майкоп» на } 2016 \text { - } \\
2018 \text { годы }\end{array}$ & $\begin{array}{l}\text { млн. } \\
\text { руб. }\end{array}$ & 7828 & 8484 & 9244 & 10103 & 27831 \\
\hline 2. & $\begin{array}{l}\text { Количество } \\
\text { сформированных } \\
\text { инвестиционных } \\
\text { проектов }\end{array}$ & $\begin{array}{l}\text { Инвестиционный } \\
\text { каталог Республики } \\
\text { Адыгея }\end{array}$ & Ед. & 16 & 17 & 18 & 19 & 54 \\
\hline 3. & $\begin{array}{l}\text { Количество } \\
\text { сформированных } \\
\text { инвестиционных } \\
\text { площадок }\end{array}$ & $\begin{array}{l}\text { Инвестиционный } \\
\text { каталог Республики } \\
\text { Адыгея }\end{array}$ & Ед. & 15 & 16 & 17 & 18 & 51 \\
\hline
\end{tabular}

Привлечение инвестиций в экономику города - важнейшая стратегическая задача дальнейшего развития экономического потенциала города. На данном этапе важным является продолжение проведения мероприятий, направленных на создание условий для привлечения инвестиций в экономику муниципального образования «Город Майкоп». Результатом всех мероприятий должно стать увеличение притока российских и иностранных инвестиций, внешнеэкономической предприятий и организаций.

Разработка и реализация программы по продвижению имиджа муниципального образования "Город Майкоп" в России и за рубежом позволит сформировать в международном

бизнес-сообществе привлекательный инвестиционный имидж и занять собственную нишу в растущей конкуренции городов мира за привлечение не только инвестиционных, но и людских ресурсов: талантливых людей, креативных профессионалов и менеджеров как главного ресурса постиндустриальной эпохи.

\section{ЛИТЕРАТУРА}

1. Инвестиции / Формирование инвестиционной привлекательности. [Электронный ресурс]. - Режим доступа: http://investers.ru/investitsionnie-proekti-ot-modelirovaniyado-realizatsii/formirovanie-investitsionnoy-privlekatelnosti.html.

2. Лукасевич И.Я. Финансовый менеджмент: Учебник - М.: Эксмо, 2015. - 236 с.

3. Официальный сайт Федеральной службы государственной статистики РФ [Электронный ресурс]. - Режим доступа: http://www.gks.ru/. 


\title{
ОСНОВНЫЕ АСПЕКТЫ ИНВЕСТИЦИОННОЙ ПРИВЛЕКАТЕЛЬНОСТИ МУНИЦИПАЛЬНОГО ОБРАЗОВАНИЯ
}

Хамуков А. $A$. Студент 2 курса магистратуры, Адыгейский государственный университет, г. Майкоп Научный руководитель: Тамов $А$. $A$. д.э.н., профессор, Адыгейский государственный университет, г. Майкоп

\begin{abstract}
Аннотация. В данной статье раскрывается понятие инвестиционной привлекательности муниичипльного образования, а так же описываются основные существующие методы ее оценки, с указанием их достоинств и недостатков.

Ключевые слова: муниципальное образование, инвестиционная привлекательность, инвестиционный потенциал, инвестиционный риск, конкурентный потенциал, конкурентная позиция, факторы инвестищионной привлекательности.
\end{abstract}

KEY ISSUES OF INVESTMENT ATTRACTIVENESS OF THE MUNICIPALITY'S.

Khamukov A.A. student of 2 course of magistracy, Adygei state university, Maikop Research supervisor: Tamov A.A. Doct.Econ.Sci., professor, Adygh state university, Maikop

\begin{abstract}
This article deals with the concept of investment attractiveness of the municipality, and also it describes the main existing methods of assessment, indicating their advantages and disadvantages.

Key words: municipality, investment attractiveness, investment potential, investment risk, competitive potential, competitive position, investment attractiveness factors.
\end{abstract}

В рамках существующей многоуровневой стратегии территориального развития России, включающей в себя принципы управления, как сверху, так и внутреннего саморегулирования, образования стали муниципаль ные субъектами самостоятельного принятия экономических решений и проведения определенной социально-эконом ической политики на своих территория х.

Так как финансовые средства, необходимые для реализации планов социально экономического развития, ограничены, возникает необходимость привлечения дополнительных средств за счет инвестирования. Последнее требует создания определенных условий для привлечения капитала, в том числе и иностранного, в хозяйствующие объекты на территории муниципального образования. Стоит так же понимать, что привлечение инвестиций - это один из наиболее эффективных способов преодоления застойного состояния в экономике, как региона в целом, так и муниципального образования, в частности. Реализация вопросов привлечения инвестиций на данном уровне осуществляется в виде инвестиционной политики города - совокупности методов и инструментов, используемых органами местного самоуправления по созданию и повышению инвестиционного климата муниципального образования с целью решения социально-экономических задач города. Инвестиционная политика муниципального образования должна учитывать то, что город рассматривается как более сложная система, чем просто территориальное образование.

Современный этап развития экономики, как и все другие территориальные образования, анализируется с точки зрения системного подхода. При данном подходе муниципаль ное образование рассматривается, как отдельная социально-эко номическая система, включающая в себя различные сектора 
ЭКОНОМики,

политические,

культурно -

социальные и некоммерческие структуры. С точки зрения менеджмента МО можно представить как иерархическую хозяйствующую систему, т.е. объект управления.

В экономической теории и практике в инвестицио нном процессе используются два понятия: инвестиционная привлекательность и инвестиционный климат. Некоторые авторы придерживаются позиции, что данные понятия различны: инвестиционная привлекательность, так же, как и инвестиционная активность, которая характеризует объем инвестиций за анализируемый период, вместе являются элементами инвестиционного климата. Однако большинство ученых-экономистов отождествляют эти понятия, не выделяя существенных различий [1,2].

В экономической литературе наиболее часто встречается следующее определение: инвестицио нная привлекательнос ть хозяйственной системы является обобщенная характеристика совокупности социальноэкономических, организацио нно-правов ых, политических, социокультурных предпосылок, предопределяющих привлекательность и целесообразность инвестирования в ту или иную хозяйственную систему. Также, понятие «инвестиционный климат» отражает степень благоприятности ситуации, складывающейся в том или ином регионе, городе, отрасли по отношению к инвестициям, которые могут быть сделаны в другой регион город, отрасль.

В данных определениях основной акцент делается на совокупность условий территориального образования, которые влияют на положительное принятие решения об инвестировании. Инвестиционная привлекательность, в отличие от других экономических категорий, не характеризуется динамичностью, она не способна быстро реагировать на изменения факторов внешней среды. Понятие инвестиционного климата характеризуется сложностью

\section{и} комплексностью.

B

отечественной инвестицио нная

привлекатель но с ть определяется как отождествление с инвестицио нным климатом, так и как такая характеристика, как «платежеспособ ный спрос территории на инвестиции». Следует особо отметить, что при оценке инвестиционной привлекательности города институты местного рынка инвестиций: инвестор, заемщик, местные органы управления и т.д. по-разному трактуют понятие инвестиционной привлекательност и города.

Показатели

инвестицио нно й привлекательности реализуются как на макро-, так и на микроуровне:

- на макроуровне реализуются факторы политической (включая законодательство), экономической и социальной среды для инвестиций;

- на микроуровне инвестиционный климат проявляется на уровне взаимовыгодных отношений фирмы-инвестора и субъектов территории-реципиента (государственных органов, хозяйственных субъектов, поставщиков, покупателей, банков, а также профсоюзов и трудовых коллективов). На этом уровне происходит конкретизация обобщенной оценки инвестиционного климата в ходе реальных экономических, юридических, культурных контактов инвестирующей фирмы с новой для нее средой.

Макро- и микроуровни инвестиционного климата реализуются как единое целое. Любые факторы внешней среды (законодательные действия Федерального Правительства по формированию инвестиционного климата могут не соответствовать законодательно му производству местного уровня и наоборот, льготы муниципалитета могут дополнять положения Федерального правительства. Комплексность и сложность категории «инвестиционная привлекательность » обусловлена тем, что нет однозначного подхода к определению этого понятия.

Для инвестора город инвестиционно привлекателен, если маржинальные издержки размещения нового производства в городе 
равны маржинальному доходу. Для хозяйствующего субъекта городской экономики - это степень благоприятности местных условий его инвестиционной деятельности.

Инвестицио нная привлекательность в таком случае определяется как совокупность находящихся под влиянием местных властей универсальных условий для хозяйственно й деятельности и инвестиций, определяемых городским хозяйственным регулированием, традициями и практикой хозяйственных отношений, влияющих на принятие решений об изменениях масштабов и характера производства.

Эти условия формируются при реализации инвестиционных проектов, а также определяющих возможность окупаемости этих проектов и получения прибыли. Приведенное определение инвестиционной привлекательности города может использоваться муниципальными органами власти в территориальном маркетинге города, то есть при реализации задач муниципального управления для позиционирования города на внешних инвестиционных рынках. Несмотря на то, что в определениях инвестиционно й привлекательности города акценты сделаны на различные критерии, основной является такая характеристика города, как конкурентоспособность .

Анализ видов конкуренции за инвестиции проводится исходя из модели пяти сил конкуренции М.Портера. На основе этой модели

Иванов В.В. и Коробова М.П. разработали оценку конкурентоспособности города, которая может быть применима для оценки ИПГ.

Конкурентный статус (инвестицио нная привлекательность) муниципального образования является функцией от двух аргументов: конкурентоспособност и муниципального образования (КС) и конкурентного потенциала муниципального образования (КП):

ИП $=\mathrm{X} \times \mathrm{KC}+\mathrm{Y} \times \mathrm{K \Pi ,} \mathrm{(1)}$

где $\mathrm{X}$ и $\mathrm{Y}$ - весовые коэффицие нты, отражающие вклад КС и КП в инвестицио нную

привлекатель но с ть муниципального образования, определяемые экспертным путем, например по 100-ти балльной шкале;

КС - отражает эффективность функцио нирования муниципаль но го образования в краткосрочном периоде.

Показатель КС является интегральным показателем, его параметрами являются показатели уровня жизни населения на территории города в сравнении с базовым уровнем, определенным законодательно, или в сравнении с уровнем более сиљьного конкурента.

КП - конкурентный потенциал или сила конкурентной позици, способность эффективного муниципаль ного функцио нирова ния образования B перспективном периоде, определяется факторами, которые могут привлекать и удерживать потенциальных инвесторов.

Уровень конкурентного потенциала города определяется наличием следующих факторов:

- наличие стратегического плана развития муниципального образования; интеллектуаль ный потенциал муниципального образования;

- потенциал развития базовых отраслей экономики города; величина входного барьера в муниципальном образовании (стоимость аренды нежилых помещений, земли в ближайшем будущем;

- планируемые изменения в местном налогообложении и льготы;

- местные нормы, стандарты; лицензирование, сертификация отдельных видов деятельности, не подлежащих лицензированию в других муниципаль ных образованиях и трудность процедуры оформления; особенности местнй культуры); потенциал рынка труда;

- прогнозы развития рынка;

- предпринимательский климат: отношение власти и общества к бизнесу; 
- стабильность муниципальной политики в области предпринимательства;

- льготные налоговые режимы (свободные экономические зоны);

- создание инновационных центров;

- система защиты интеллектуально й собственности;

- упрощение процедур регулирования хозяйственной деятельности;

- возможность официальных действий через Интернет - порталы и пр.

Недостатком использования кластерного анализа для оценки конкурентоспособности и инвестицио нно й

привлекатель но сти муниципального образования

является отсутствие учета рисков. Вместе с тем, оценка рисков осуществляемых проектов может дать важную информацию о конкурентном статусе муниципального образования,

дать адекватную оценку инвестиционно й привлекательности, позволит построить прогноз развития муниципального образования долгосрочном периоде.

Поэтому в общий алгоритм оценки конкурентоспособности и конкурентного статуса необходимо включить оценку факторов риска, как для конкретных проектов, так и для муниципального образования в целом, выявив предварительно источники рисков и проведя их классификацию с учетом специфики конкретного муниципального образования.

Также при оценке инвестицио нно й привлекательности города можно использовать метод, выделенный Н.В. Игошиным в своей монографии «Инвестиции. Организация управления и финансирования», так называемый «суженый подход» При использовании суженого метода оценивается динамика основных показателей хозяйственной деятельности (ВВП, НД, объемы производства, динамика распределения НД, пропорций потребления и накопления и потребления, ход приватизационных процессов, состояние законодательного регулирования инвестицио нно й отдельных инвестиционных рынков, в том числе фондового и денежного).

За основной показатель оценки инвестицио нной привлекательности хозяйственной системы, в том числе и города, принимается уровень прибыльности используемых активов, рассчитанный по двум вариантам:

1. Отношение прибыли от реализации товаров и услуг к общей сумме используемых активов;

2. Отношение балансовой прибыли к общей сумме используемых активов.

Данный подход считается универсальным, то есть используется для оценки инвестицио нно й привлекательности хозяйственной системы любого уровня. Положительным в данном методе является относительная простота расчетов и анализа. Кроме того, указанный подход еще и достаточно дешев, поскольку не требует проведения дополнительных статистических исследований. Недостаток заключается в том, что не отражен баланс интересов, а «инвестиционный климат не связан с инновацио нным типом развития, экономической устойчивостью. В нем полностью игнорируются объективные связи фактора инвестиций с другими ресурсными факторами развития хозяйственных систем». Каждый город отличается особенностями производства и жизнедеятельности, что определяет свой набор факторов. Но из этого набора можно выделить универсальный набор факторов, который может быть использован для оценивания инвестиционно й привлекательности в целом. В этот набор входит: географическое положение; обеспеченность природными ресурсами и их доступность; состояние окружающей среды; структурное разнообразие экономики; состояние и развитие инфраструктуры рынка; развитие культуры и образования населения; социально-политическая стабильность; экономическая стабильность; взаимодействие органов управления с предприятиями; информационное и коммуникационное поле; нормативно-правовое поле; система льгот инвесторам [3]. 
Исследование проблем инвестирования всегда находилось в центре внимания экономической науки. Это обусловлено тем, что инвестиции затрагивают самые глубинные основы хозяйственно й деятельности, определяя процесс экономического роста в целом. В современных условиях они выступают важнейшим средством обеспечения условий выхода из сложившегося экономического кризиса, структурных сдвигов в народном хозяйстве, обеспечения технического прогресса, повышения качественных показателей хозяйственной деятельности на микро- и макро уровнях. Активизация инвестиционного процесса является одним из наиболее действенных механизмо в социально-эко ном ических преобразований.

Инвестиции с наибольшей эффективностью могут осуществляться в тех городах, где для этого созданы наиболее выгодные условия, поэтому для принятия решения об инвестировании, как в информационном, так и в методическом плане, важную роль играет адекватная оценка и прогнозирован ие инвестицио нного климата муниципального образования.

Использование инструменто в территориального маркетинга в стратегическом муниципальном управлении способствует формированию позитивного имиджа территории, создавая тем самым конкурентное преимущество территории, привлекательность м муниципального образования для инвестиций по сравнению с другими муниципальными образованиямиконкурентами.

\section{ЛИТЕРАТУРА}

1. Игошин, Н.В. Инвестиции: организация, управление, финансирование: учебник М.: ЮНИТИ, 2016. -234 с.

2. Иневатова, О.А. Региональная экономика: учебное пособие / О.А. Иневатова, С.А. Дедеева, Ю.А. Макарова // - СПб.: Питер, 2015. - 344 с.

3. Кузнецов, Б. Т. Инвестиции: учебное пособие. - М.: ЮНИТИ-ДАНА, 2015. - 236 с. 


\title{
РЕГИОНАЛЬНЫЕ АСПЕКТЫ КАДРОВОЙ ПОЛИТИКИ В СИСТЕМЕ ГОСУДАРСТВЕННОГО УПРАВЛЕНИЯ
}

Юрченко Е. $А$

Магистрантка 2 курса, Адыгейский государственный университет, г. Майкоп

Научный руководитель: Хатукай С.A. к.э.н., доцент, Адыгейский государственный университет, г. Майкоп

\begin{abstract}
Аннотация. В данной статье отражены проблемы формирования кадрового резерва государственных и муниципальных служащих на региональном уровне. Рассматриваются цеели и современные концепщии государственной кадровой политики, описываются условия обеспечения высокой профессиональной подготовки государственных и муниципальных служаших.

Ключевые слова: государственная кадровая политика, проблемы, система исполнительной власти, государственнье и мунищипальные служсащие, кадровая работа.
\end{abstract}

\section{REGIONAL ASPECTS OF THE PERSONNEL POLICY IN THE PUBLIC ADMINISTRATION SYSTEM}

Yurchenko EA

Magistrant 2 course, Adygeistate university, Maikop Research supervisor: Khatukay $S A$ Cand.Econ.Sci., Associate professor, Adygeistate university, Maikop

\begin{abstract}
This article is devoted of the problem of formation of personnel reserve of state and municipal employees at the regional level. Consider the purpose and concept of the modern state personnel policy, describes the conditions ensuring high professional training of state and municipal employees.

Keywords: state personnel policy, the problems, the system of executive power, state and municipal officials, personnel work.
\end{abstract}

Современная ситуация на рынке труда, эффективное обслуживание субъектов рынка труда, количественно-качественная сбалансированность предложения со стороны персонала формируются под влиянием политической и социально-экономической ситуации в стране и конкретно в регионах. На сегодняшний день актуальными являются проблемы разработки и реализации кадровой политики в различных секторах экономики рыночного типа. Главным источником формирования трудовых ресурсов, их количественного и качественного аспектов является, в первую очередь, население региона.

Под кадровой политикой на государственной (муниципальной) службе понимается общий курс и последовательная деятельность государства по формированию требований к государственным служащим, по их подбору, подготовке и рационального использованию с учетом состояния и перспектив развития государственного аппарата, прогноза о качественных и количественных потребностях в кадрах государственных служащих.

Кадровая политика призвана в полной мере использовать творческий потенциал служащих, их энергию и способности к решению назревших проблем; помочь государственным и муниципальным служащим наиболее полно раскрыть свои таланты, умения и способности. На основе такого подхода есть вероятность повысить качество работы служащих и обеспечить решение важнейших государственных программ в экономической, культурной, социальной и других сферах.

Главным принципом рыночной экономики, определяющим стратегическую цель кадровой политики любого уровня в рыночных условиях является - рентабельность, т.е. эффективное 
использование имеющихся ресурсов с получением максимально возможной прибыли с наименьшими затратами путем наиболее полного удовлетворения спроса на товары или услуги потребительского сектора рынка. Реализуя этот принцип не только на уровне одного предприятия, но и в региональном, государственном масштабе, можно получить выгоду, в форме таких социальноэкономических дивидендов, как обеспечение трудовой занятости населения, повышение уровня жизни людей, социальной защиты малообеспеченных слоев населения, укрепление социальной стабильности, ускорение экономического роста и развития отдельных регионов и страны в целом [3].

В исторической практике России четко просматриваются две основные концепции кадровой политики:

1) высокоцентрализованная - с широким использованием принципа назначения руководящих кадров государственной службы при ограничении демократических механизмов их выдвижения и расстановки (выборности, учета общественного мнения, коллегиальности решения кадровых вопросов и др.);

2) демократическая - система формирования и развития кадрового корпуса, хотя и централизованная, единая в рамках государства (на основе единства целей, принципов, стандартов при назначении на должность и обучении кадров).

В настоящее время в России прослеживается сочетание этих конщепций государственной кадровой политики. Без назначения на должность государственное и муниципальное управление не может функционировать в принципе, но сам механизм назначения может опираться на разные подходы: субъективную волю руководителя,

централизованные,

излишне

бюрократические оценки работников (главное не профессионализм, компетентность, а верность начальнику, лидеру) или на волю народа, социума (региона, района, коллектива), демократические механизмы выявления и реализации этой воли в особенности на основе гласности, выборности, отчетности.
Новая для российского государства система государственного управления, формируемая на принципах конщентрации и децентрализации, определяют объективную необходимость формирования новой конщепщии кадровой политики.

Формирование кадров государственной службы является важнейшим вопросом стратегии и тактики органов государственной власти на федеральном и на региональном уровнях. В сфере государственного управления востребованы профессионально подготовленные государственные служащие, исполняющие свои должностные обязанности по обеспечению эффективного взаимодействия всех участников регионального рынка, независимо от масштаба и форм собственности. От эффективности деятельности подразделений государственной службы, призванной осуществлять контроль и регулирование социально-экономических, правовых отношений хозяйствующих субъектов, во многом зависит успешность развития экономики регионов.

В органах государственного управления до сих пор преобладает закрытая кадровая политика. Такая политика без существенного притока перспективных новых кадров может быть эффективной только при условии формирования и полноценной работы с кадровым резервом. «Кадровый резерв это группа специалистов и руководителей, которые могут осуществлять управленческую деятельность и отвечают требованиям, предъявляемым должностью определенного ранга, а также подвергшиеся отбору и прошедшие целевую систематическую квалификацио нную подготовку» [1].

Основные цели формирования резерва кадров - создание подготовленного к управлению в новых условиях состава государственных служащих, обеспечение непрерывности и преемственности процесса управления, движение кадров по вертикали и горизонтали, подготовка и выдвижение кадров, способных реализовывать задачи и функции органов государственной власти [3]. Формирование кадрового резервадолжно происходить по двум направлениям - оперативному

И 
стратегическому. Оперативная часть формируется из сотрудников подразделений, как правило, это либо заместители начальников, либо ведущие специалисты - те, кто может в случае необходимости заменить руководителя. Специфика планирования стратегического кадрового резерва состоит в том, что резерв необходимо планировать, исходя из фактической организационно управленческой структуры и кадрового состава, с учетом планирования и прогноза развития организации и изменения еe кадрового состава.

В 2012 году научными сотрудниками Адыгейского республиканского института гуманитарных исследований было проведено социологическое исследование среди государственных служащих Республики Адыгея с целью изучения проводимой кадровой политики. Было опрошено 110 чиновников. Результаты опроса оказались следующими.

Среди опрошенных государственных служащих Республики Адыгея оказалось 47\% мужчин и 53\% женщин, причем среди руководителей доля мужчин превышала долю женщин. Выборка отражает существующие тенденции распределения государственных служащих по гендерному признаку в системе государственной службы, когда на более высоких должностях доля мужчин оказывается несколько больше, чем женщин. По стажу работы на государственной службе наиболее многочисленной группой в выборке - около $30 \%$ - оказались госслужащие со стажем работы 10-15 лет. Вторая по объему группа одна пятая всей выборки - часть госслужащих со стажем 7-10 лет. Самой малочисленной оказалась группа госслужащих со стажем работы до одного года - около $3 \%$.

Организационные цели и стратегии достижения этих целей имеют значение лишь тогда, когда люди, обладающие требуемыми талантами и умением, занимаются достижением этих целей.

Грамотно спроектированное кадровое
планирование должно дать четкие,
однозначные ответы на данные вопросы:

-каким образом можно привлечь необходимый и сократить излишний персонал, учитывая социальные аспекты (планирование привлечения или сокращения штатов);

-сколько работников, какой квалификации, когда и где будут необходимы (планирование потребности в персонале);

-каким образом можно использовать работников в соответствии с их способностями (планирование использования кадров);

-каких затрат потребуют планируемые кадровые мероприятия (расходы по содержанию персонала);

-каким образом можно целенаправленно содействовать повышению квалификации кадров и приспосабливать их знания к меняющимся требованиям (планирование кадрового развития).

Государственная кадровая политика реализуется в субъектах РФ посредством кадровой работы высших региональных исполнительных органов, в том числе Администрации Республики Адыгея. Она в своем составе имеет Управление государственной службы и организационно й работы. В своей деятельности данное Управление руководствуется статьями Конституции РФ, федеральными конституционными законами, федеральными законами, нормативными правовыми актами Президента и Правительства РФ, Трудовым кодексом РФ, Уставом (Основным законом) Республики Адыгея, законами республики, постановлениями и распоряжениями Администрации республики, приказами (поручениями) начальника Управления [4].

Кадровая работа Администрации Республики Адыгея осуществляется по основным направлениям, которая реализуется всеми органам исполнительной власти РФ:

- участие в проведении служебных проверок, осуществляемых в соответствии с законодательством о государственной гражданской службе, деятельности комиссии по урегулированию конфликтных ситуаций, комиссии по служебным спорам; 
- участие в формировании кадрового состава для замещения должностей гражданской службы в Администрации;

- обеспечение подготовки проектов актов Администрации, связанных с поступлением на гражданскую службу, ее прохождением, заключением служебного контракта, назначением на должность гражданской службы, освобождением от замещаемой должности гражданской службы, увольнением гражданского служащего с гражданской службы, и выходом его на пенсию за выслугой лет;

- ведение реестра гражданских служащих, замещающих должности в Администрации;

- организация и обеспечение проведения конкурсов на замещение вакантных должностей гражданской службы в Администрации и включение гражданских служащих в кадровый резерв;

- организация и обеспечение проведения аттестации гражданских служащих, замещающих должности в Администрации;

- участие в обеспечении должностного роста государственных служащих, замещающих должности в Администрации;

- участие в организации профессиональной переподготовки, повышении квалификации и стажировки гражданских служащих, замещающих должности в Администрации.

Для кадрового обеспечения органов исполнительной власти в республике Адыгея существует проблема преодоления стихийности в подготовке кадрового резерва в администрациях, что связано с нестабильностью аппарата и всего корпуса руководителей. Это обуславливает такие проблемы как:

1) неопределенность с выборами глав администраций и представителей органов власти;

2) неясность механизма государственных служащих;

3) противоречивость и медлительность процесса формирования государственной службы в РФ в целом.

По результатам опроса госслужащих Администрации Республики Адыгея, выявились негативные проявления в кадровой сфере государственного (или муниципаль ного) органа управления:

- низкий авторитет институто в государственной службы у населения;

- нестабильность структур государственных учреждений, частую их реорганизацию;

- непродуманность прохождения службы: по мере повышения в должности ответственность возрастает быстрее, чем служебные возможности и заработная плата;

- отсутствие действенного контроля и ответственности чиновников за некачественное и недобросовестное выполнение своих обязанностей;

- отсутствие гибкой и справедливой системы оплаты труда;

- влияние на карьерный рост «семейных» факторов, политических ориентаций.

Сами госслужащие Администрации республики Адыгея в ходе опроса внесли свои предложения по улучшению деятельности регионального управления в сфере проведения кадровой политики:

- привлечение к руководству профессионалов, грамотных людей;

- сокращение числа чиновников и упрощение структуры аппарата;

- увольнение недостойных

И неквалифицированных работников;

- усиление общественного контроля за их деятельностью;

- повышение зарплаты управленцам;

- выборность руководителей всех уровней.

Сотрудникам органов исполнительной власти уже недостаточно лишь опыта в работе. Сейчас необходимо

постоянное самосовершенствование, приобретение новых знаний. Именно синтез качеств, умений, навыков, опыта, теории, практики, приобретенных знаний в процессе учебы и уважения к людям дает основания заявлять о государственном служащем как о профессионале.

Становится ясно, что четкая государственная кадровая доктрина - главное на сегодняшний день в процессе формирования государственного и муниципального управления [2]. Однако, повышение авторитета и престижности государственной службы, 
создание надлежащих социально-правовых и социально-экономических условий, пресекающих такие раздражающие общество явления, как коррупция, ориентирование на «случайный» приток людей в аппараты управления, автоматически выталкивающий оттуда компетентных специалистов, обретают особую значимость. Ставка на интеллектуального управленца, его компетентность, профессионализм и эффективные информационные технологии один из главных путей совершенствования кадровой работы органов исполнительной власти.

В настоящее время, как показывает практика, проблема формирования высокопрофессионального, качественного корпуса государственных и муниципаль ных служащих становится одной из сложнейших проблем любой государственной системы. Здесь проявляются такие неоднозначные вопросы, как совершенствование системы отбора кадров на государственную службу, научный подход к анализу потребностей в управленческом персонале, разработка научных критериев их оценки, формирование эффективных технологий расстановки и продвижения кадров, повышение обоснованности кадровых решений и расширение их гласности и т. п.

В сфере работы с кадрами органов исполнительной власти пока больше проблем, чем позитивных результатов. В большинстве регионах России отсутствуют долгосрочные перспективы в подготовке и использовании кадров, кадровая политика зачастую носит бессистемный характер, благодаря чему оказывается несогласованной с программами социального и экономического развития территорий, в ней отсутствует продуманная система подбора и перемещения кадров [3].

Итак, проблема стабильности государственного (муниципального) аппарата и корпуса государственных (и муниципальных) служащих, скорейшее обеспечение органов власти государственно-мыслящими, квалифицированными кадрами становится важнейшей задачей кадровой работы органов исполнительной власти и проведения государственной кадровой политики в целом. В первую очередь необходимо решить задачу в работе с кадрами, к которой следует отнести повышение научной обоснованности государственной кадровой политики, профессионального развития персонала государственной и муниципальной службы, создание новой системы работы с кадрами расширение сети и качественное обновление государственно-образовательных учреждений и кадровых служб государственных и муниципаль ных органов, освоение мирового опыта в управлении человеческими ресурсами.

\section{ЛИТЕРАТУРА}

1. О государственной гражданской службе РФ: федер. закон от 27.07.2004 г. № 79 -Ф3 (ред. от 29.03.2008) // Собр. законодательства Рос. Федерации. 02.08.2004. № 31. Ст. 3215.

2. Радченко, А. И. Основы органов исполнительной власти: системный подход. - Ростов н/Д, 2010. - С. 228.

3. Слепцов. Н. С. Проблемы формирования государственной региональной системы подготовки, переподготовки и повышения квалификации государственных служащих // Социологическое обеспечение государственной службы. - М., 2010 . № 10. C. 8 .

4.Устав (Основной Закон) Республики Адыгея Российской Федерации (принят Парламентом Республики Адыгея 10 марта 1995 года) (с изменениями и дополнениями). 


\section{РАЗДЕЛ II}

\section{ЭКОНОМИКА И УПРАВЛЕНИЕ ПРЕДПРИЯТИЯМИ, ОТРАСЛЯМИ, КОМПЛЕКСАМИ}




\title{
PR В РОССИИ: ТЕНДЕНЦИИ И ПЕРСПЕКТИВЫ
}

\author{
Бюллер Е.A.
}

к.э.н., доиент, Адыгейский государственный университет, г. Майкоп

\begin{abstract}
Аннотация: Потребность в public relations возникает в обществе на определенном этапе развития, когда государство и общество становятся взаимозависимыли, потому что пиар, в отличие от манипуляциии общественным мнением, дорога с двусторонним движением.
\end{abstract}

Ключевые слова: «public relations», «коммуникаиия», «бренд», «имидж», «репутащия»

\section{PR IN RUSSIA: TRENDS AND PROSPECTS}

Byuller E.A.

Cand.Econ.Sci., associate professor, Adygei state university, Maikop

\begin{abstract}
The need for public relations arises in a society at a certain stage of development, when the state and society are interdependent, because the PR, in contrast to the manipulation of public opinion, two-way street.

Keywords: «public relations», «communication», «brand», «image», «reputation»
\end{abstract}

Public relations был всегда. С тех пор, как появилась общественность, возникла и необходимость эту общественность «окучивать». Только люди еще не знали, что это - пиар. Коммуникации назывались: слухами, пророчествами, славой, авторитетом. Потом агитацией и пропагандой.

Сегодня неумолимо ослабевает влияние рекламы на потребителя сложных товаров или услуг. Мы ежедневно просматриваем какие либо печатные издания и все меньше обращаем внимания на рекламные полосы. Но читая газетные или журнальные материалы, мы обязательно обратим внимание на упомянутую в них компанию, про себя отметим, что такая фирма вообще есть на рынке и у нее дела идут эффективно. Эффективность рекламы снижается ввиду того, что современная российская целевая аудитория уже понимает, что данная информация проплачена, а значит доверять ей полностью нельзя.

Усиливающаяся конкуренция в современном бизнесе заставляет российские компании принимать новые особые меры для того, чтобы удержать своих клиентов. При оценке привлекательности

компании

такая

способность топ-менеджеров как умение видеть стратегические перспективы компании и адекватно оценивать эффективность своего бизнеса становится важным значимым фактором. Перед специалистами в области паблик-рилейшнз в сфере коммуникаций сегодня стоит важная задача коммуницировать не только информацию, но и стратегии компаний. В настоящее время в России происходит переход от конкуренции между компаниями к конкуренции эмоционально-ценностных характеристик их продукции или услуги. Это означает, что компаниям необходимо активизировать свою работу в области повышения стоимости их нематериальных активов и заняться активным управлением своей репутацией и имиджем [2].

Bce российские предприятия, которые являются потенциальными клиентами PRагентств на сегодняшний момент можно разделить на три сектора:

- самая малая - это фирмы, которые имеют выход на мировой рынок и участвуют в глобальной мировой бизнес-системе; 
- $\quad$ фирмы, ориентированные только на российский рынок;

- региональные фирмы, которые осваивают отдельные сегментырынка и не стремятся к масштабному развитию.

Две первые группы российских предприятий и западные компании, работающие на российском рынке, и считающие такие услуги необходимостью, являются в большинстве своем потребителями PR-услуг.

Желание приобщиться к мировому бизнесу наталкивает менеджеров крупных российских компаний на понимание того, что в конкурентной борьбе сырьевые ресурсы и технология уже не являются решающим фактором. Они уже должны понимать, что им необходимо ясно представлять перспективы своего бизнеса, разрабатывать стратегию и умело претворять ее в жизнь. И этому должно способствовать умелое коммуницирование происходящих в их компаниях процессов. Именно этот фактор становится одним из самых значимых при оценке инвестиционно й привлекательности компаний [1, с.234-235].

Сегодня возрастает

роль внутрикорпоративных PR-подразделений. Если раньше «внутренние пиарщики» занимались просто посредничеством между фирмой и PRагентством, то сегодня они полностью контролируют все аспекты коммуникаций фирмы.

Трудно переоценить

значимость нематериальных ресурсов. Британская компания Interbrand провела исследования, согласно которым биржевая котировка компании Coca-Cola в 24 раза превышает стоимость ее материальных активов, так в IBM доля материальных активов составила всего 17\%, в British Petrolium данный показатель составил $30 \%$. При этом самым весомым компонентом нематериальных активов данных известных компаний является именно бренд, который в денежном эквиваленте приобретает все большее значение.

PR - самостоятельный вид бизнеса в сфере услуг, а потому зависит от клиентского спроса. Каковы же потребности клиентов сегодня и какими они будут завтра?

Российские PR-агентства привлекают мировые компании, работающие в нашей стране, прежде всего знанием отечественных реалий и невысокими ценами на свои услуги. Причем второй показатель менее значим в глазах западников, чем первый. Западные клиенты обращаются к российским специалистам по корпоративному PR c несколькими типовыми запросами. Прежде всего их интересуют возможности лоббирования интересов их корпораций на федеральном и региональном уровня: изменение в благоприятную для них сторону ставок таможенных пошлин, принятие выгодных стандартов продукции, регулирование отношений с администрацией районов, где находятся производственные мощности компании.

Кроме того, западные компании обращаются в своем большинстве в российские PR-агентства с запросом обеспечить информационную поддержку процесса расширения их бизнеса. В частности - на PR-сопровождение выхода компаний на новые рынки, на открытие магазинов и их сетей, на представление новой продукции, на преодоление региональной специфики потребительского поведения и решение задач локального характера (сопровождение благотворительной и спонсорской деятельности компаний, придание ей социально ориентированного характера и проведение других акций и мероприятий).[4]

Третий тип запроса иностранные компании формируют исходя из потребности в консалтинге относительно того, что касается национальной специфики России. Речь идет о том, как правильно коммуницировать те или иные события, как правильно определить 
особенности восприятия той или иной аудитории потребителей, как вести переговоры и выступать публично, каковы системы взаимных влияний в информационном пространстве России.

Как правило, выполнение контрактов с российскими PR-агентствами контролируется специалистами по PR и коммуникациям в США или Западной Европе. Контроль этот, как правило, ненавязчив, мало заметен, поскольку западные компании в целом достаточно лояльно относятся к российским PRспециалистам и в большинстве случаев соглашаются с предлагаемыми ими подходами и креативными решениями.

Работа же PR-агентств с российскими компаниями, выходящими на мировой рынок, имеет свою специфику. Дело в том, что адаптация к условиям мирового рынка требует не только существенной реорганизации внутренней структуры бизнеса компаний, но и совершенно иной системы коммуникаций как на уровне менеджеров, так и через средства массовой информации. В этом случае проблема коммуникации во многом сводится к утверждению единых ценностных понятий: западное бизнес-сообщество, и без того настороженно относящееся к происходящему в
России, хотело бы общаться с нашими деловыми людьми "на одном языке"и получать сигналы о том, что российские партнеры разделяют общепринятые в мире правила и нормы ведения бизнеса. То, что кажется важным и существенным в России, порой не производит впечатления на западников. Например, российские менеджеры часто сталкиваются с так называемой иллюзией успеха: западные партнеры вежливо выслушивают их, улыбаются и даже высказывают высокие оценки их деятельности, но не предпринимают никаких усилий, чтобы сдвинуть реальное сотрудничество с мертвой точки до тех пор, пока не услышат от россиян фраз, созвучных культуральному контексту мирового бизнеса. Говорить о значительных достижениях российских пиарщиков в этой области пока, увы, не приходится.[3]

В любом бизнесе корпоративный PR нацелен на решение главной задачи - увеличить капитализацию и прибыльность компании. Главными же факторами преуспевания PRагентств станет способность их специалистов видеть свой бизнес в стратегической перспективе и, конечно, удерживать клиентов.

\section{ЛИТЕРАТУРА}

1.Блэк, С. Паблик Рилейшнз. Что это такое?: Пер.с англ. - М.: Новости: Модино пресс, 1990. -240 c.

2. Бюллер, Е.А. Место бренд-менеджмента в управлении имиджем организации // Сборник материалов II Всероссийской научно-практической конференции «Проблемы и перспективы социально-экономического развития регионов Юга России», 2015. - C. 234-236.

3. Виноградов, В.Г. Эффективный PR-отдел в компании. Управление, кадры, реальный результат // Управление персоналом, 2004. №4. - С.17-18.

4. Юрко, В. PR-менеджмент в российском бизнесе / В. Юрко, А. Миронова, Я. Аршинова и др. // Управление персоналом. - 2004. №4. - С.19-21. 


\title{
ОСНОВНЫЕ ТЕНДЕНЦИИ РАЗВИТИЯ ДЕНЕЖНО-КРЕДИТНОЙ СФЕРЫ РЕСПУБЛИКИ АДЫГЕЯ
}

Гидзова 3.А. Адыгейский государственный университет, г. Майкоп Научный руководитель: Мокрушин А.А., д.э.н., профессор, Адыгейский государственный университет, г. Майкоп

\begin{abstract}
Аннотация. В статье проведен анализ динамики изменения суммы просрочки по кредитам населению страны на промежуточные квартальные даты за 2015-2016 г2. Рассмотрена структура просроченных портфелей, и определены основные причины возникновения долгов граждан перед банками. На основе анализа сделаны выводы о необходимости развития собственных инструментов и технологий взыскания, направленных на выявление ранней проблемной задолженности и предотвращение просрочки.

Ключевые слова: кредитный портфель, банковская система, совокупные активы, пассивы, кредитная задолженность, розничный сегмент, инфляция.
\end{abstract}

\section{THE MAIN DEVELOPMENT TRENDS IN MONETARY SPHERE OF THE REPUBLIC OF ADYGEA}

Gidzova Z.A. Adyghe State University, Maikop Supervisor: Mokrushin A. A. PhD, Professor, Adyghe State University, Maikop

\begin{abstract}
The article provides an analysis of the dynamics of volume and annual rate of an increase of payment delay on credits to the country's population for an intermediate quarter dates for the period of 2008-2014. We consider the structure of overdue portfolios and determine the main reasons for emergence of the citizens' debts to banks. On the basis of analysis, we have concluded the need of development of proprietary tools and technologies of collecting directed on identification of early problem debt and to prevent payment delay.

Keywords: the credit portfolio of the banking system total assets, liabilities, credit debt, the retail segment, inflation
\end{abstract}

Проблемы закредитованности населения Российской Федерации все отчетливее стали способствовать ухудшению показателей качества розничных портфелей банковских организаций. Экономическая значимость снижения уровня просроченной задолженности по розничным кредитам для развития коммерческих банков и становления национальной банковской системы определила основную цель авторов и актуальность рассматриваемых вопросов.

Для анализа и характеристики основных направлений развития инструментов денежно-кредитной политики, необходимо понимание ее сущности. Денежно-кредитная политика представляет собой политику государства, воздействующую на объем денежной наличности в обращении с целью обеспечения стабильности цен, полной занятости населения и роста реального производства. На сегодняшний день Банк России предусматривает сохранение структурного дефицита ликвидности банковского сектора на период 2016-2018гг. В течение данного периода прогнозируется сокращение потребности кредитных организаций в рублевом рефинансировании Банка России, что обусловлено главным образом притоком ликвидности в банковский сектор за счет использования средств суверенных фондов в связи с необходимостью финансирования расходов федерального 
бюджета. При этом увеличение объема ликвидности из банковского сектора. наличных денег в обращении на фоне Прогнозные значения ключевых показателей восстановления российской экономики экономики РФ, по расчетам Центрального приведет к незначительному оттоку Банка РФ, представлены в таблице 1 .

\section{Таблица 1 - Основные показатели экономики РФ (по прогнозам Банка России) за 2016- 201822.}

\begin{tabular}{|l|c|c|c|c|c|c|}
\hline \multirow{2}{*}{ Показатели } & \multicolumn{2}{|c|}{ 2016г. } & \multicolumn{2}{c|}{ 2017г. } & \multicolumn{2}{c|}{ 2018г. } \\
\cline { 2 - 7 } & $\begin{array}{c}\text { базовый } \\
\text { вар-т }\end{array}$ & $\begin{array}{c}\text { опти- } \\
\text { мистич. } \\
\text { вар-т }\end{array}$ & $\begin{array}{c}\text { базовый } \\
\text { вар-т }\end{array}$ & $\begin{array}{c}\text { опти- } \\
\text { мистич. } \\
\text { вар-т }\end{array}$ & $\begin{array}{c}\text { базовый } \\
\text { вар-т }\end{array}$ & $\begin{array}{c}\text { опти- } \\
\text { мистич. } \\
\text { вар-т }\end{array}$ \\
\hline $\begin{array}{l}\text { ВВП, прирост, к предыду- } \\
\text { щему году, \% }\end{array}$ & $(0,5-1,0)$ & $0,0-0,5$ & $0,0-1,0$ & $1,0-2,0$ & $2,0-3,0$ & $2,5-3,5$ \\
\hline Инфляция, \% & $5,5-6,5$ & $5,5-6,5$ & 4,0 & 4,0 & 4,0 & 4,0 \\
\hline $\begin{array}{l}\text { Денежная масса в националь- } \\
\text { ном определении }\end{array}$ & $4-7$ & $8-10$ & $8-11$ & $13-16$ & $13-16$ & $13-16$ \\
\hline
\end{tabular}

С учетом указанных тенденций в базовом сценарии темпы прироста российской экономики останутся отрицательными в 2016г., а затем будут постепенно восстанавливаться. В данном сценарии при низком внешнем спросе и неблагоприятной ценовой конъюнктуре мировых товарных рынков стоимостный объем российского экспорта будет расти очень медленно, однако темпы роста спроса на импорт также будут относительно низкими, что в совокупности обеспечит сохранение стабильных уровней сальдо торгового баланса и сальдо текущего счета платежного баланса России.

По прогнозу Банка России, задолженность кредитных организаций по операциям рефинанс ирования будет в основном зависеть от объема потребности в использовании или накоплении средств Резервного фонда на трехлетний период. В базовом сценарии задолженность кредитных организаций к 2018 году может составить 1,0 трлн. руб., а в оптимистичном - увеличиться до 5,3 трлн. руб.

Другим направлением деятельности Банка России в 2016-2018гг. является совершенствование

технологичес ких аспектов проведения операций. В частности, предполагается организация доступа к трехсторонним сервисам управления обеспечением по операциям с корзиной обеспечения через биржевые и внебиржевые каналы предоставления ликвидности. В свою очередь, Банк России также планирует развивать электронный документооборот с кредитными организациями при проведении операций по предоставлению кредитов, обеспеченных нерыночными активами. В течение 2016-2018гг. Банк России также планирует работать в направлении улучшения расчетно-клиринговой инфраструктуры российского финансового рынка с акцентом на развитие и диверсификацию систем управления обеспечением по операциям репо. Данная мера включает осуществление интеграции российского фондового и денежного рынков с международным и депозитарными системами и системами управления обеспечением.

Таким образом, в ближайшие время Банк России продолжит работу по повышению согласованности времени работы платежной 
системы, финансовых рынков и времени проведения операций. Данные обстоятельства позволят у увеличить эффективно сть перераспределения ликвидности

B

банковском секторе и сократить операционные издержки кредитных организаций, а также будет способствовать созданию условий для повышения эффективности механизма реализации денежно-кредитной политики в результате уменьшения частоты использования кредитными организациями операций Банка России постоянного действия по предоставлению рублевой ликвидности.

Банковская система Республики Адыгея по состоянию на октябрь 2016г. представлена четырьмя действующими кредитным и организациями и тремя филиалами действующих кредитных организаций других регионов. При этом два филиала действующих кредитных организаций имеют корреспондентские субсчета в региональном Отделении Национального банка Республика Адыгея.

В сравнении с тремя кварталами 2015г. число филиалов кредитных организаций других регионов в Республике Адыгея сократилось (на две ед.), что связано с их преобразованием в структурные подразделения. Требованиям к контрагентам Банка России по денежно-кредитным операциям соответствуют все кредитные организации, функционирующие

B
Республике Адыгея.

Анализ востребованности инструментов денежно-кредитного регулирования за три квартала 2016г. позволил сделать ряд промежуточных выводов. Во-первых, в течение отчетного периода системой рефинансирования в Республике Адыгея были охвачены все кредитные организации республики (4 ед.) и один филиал кредитной организации другого региона $(33,3 \%$ от общего числа филиалов действующих кредитных организаций других регионов или $50 \%$ филиалов, имеющих корсубсчета в Отделении НБ Республики Адыгея). В течение отчетного периода банки, будучи альтернативным инструментом размещения временно свободных денежных средств, также использовали межбанковский рынок.

Во-вторых, лишь за три квартала 2016г. все кредитные организации Республики Адыгея разместили на межбанковском кредитном рынке 4700 млн. руб., что снизилось в сравнении с аналогичным периодом 2015г. в 1,4 раза. Наибольший объем размещенных средств в Республике Адыгея составили кредиты (депозиты), предоставленные на срок «от 2 до 7 дней» (3700 млн. руб. или $76,6 \%$ общего объема). Удельный вес кредитов (депозитов) на срок «на 1 день» составил 12,8\% (600 тыс. руб.), на срок «от 8 до 30 дней» - 10,6\% (500 тыс. руб.). Кредитные организации в Республике Адыгея за три квартала 2016г. привлекли на межбанковском кредитном рынке 8,5 млн. рублей (в сравнении с аналогичным периодом 2015 г. снижение составило 6,4 раза). При этом на 01.10.2016г. привлеченные кредиты Банка России отсутствовали. При этом весь объем межбанковских кредитов был привлечен на срок 1-3 года.

В-третьих, кредитный портфель заемщиков Республики Адыгея за три квартала 2016г. снизился на 2,0\%, составив 46,3 млрд. руб. При выборе валюты кредитования клиенты банков отдавали предпочтение националь но й валюте. Доля ссуд в иностранной валюте кредитных организаций Республики Адыгея на 01.10 .2016 г. составила $0,1 \%$ (на 01.01.2016г. - 0,9\%).

Наибольшей активностью на региональ ном кредитном рынке за анализируемый период характеризовались кредитные организации других регионов, имеющие филиалы в 
Республике Адыгея, нарастившие кредитные вложения с начала 2016г. на 10,0\% (25,6 млрд. руб.). При этом доля данных организаций в общей задолженности по ссудам в Республике Адыгея увеличилась с 49,2\% на 01.01.2016г. до $55,2 \%$ на 01.10 .2016 г.

Кредитные организации, других регионов, не имеющие филиалы в Республике Адыгея, снизили кредитный портфель на 13,9\% до 18,3 млн. руб. (в связи с отзывом лицензии АО КБ «РосинтерБанк»), удельный вес в общем объеме кредитных вложений снизился с 44,5\% на 01.01.2016г. до 39,4\% на 01.10.2016г. Региональные банки снизили общий объем ссудной задолженности на $3,5 \%$ их доля в кредитных вложений на 01.10.2016г. составила лишь $5,3 \%$. Задолженность по кредитам юридических индивидуальных предпринимателей с начала 2016 года снизилась на 14,1\% до 20,1 млрд. руб., физических лиц за этот период выросла на 7,9\% до 27,1 млрд. руб.

В течение анализируемого периода в Республике Адыгея наблюдался рост кредитной «нагрузки» граждан. В частности, средний остаток ссуд, приходящихся на одного жителя Республики Адыгея, увеличился на 7,6\% (с 54,3 тыс. руб. на 01.01.2016г. до 56,9 тыс. руб. на 01.10.2016г.) на фоне роста банковских вкладов на одного жителя республики (на 2,8\% с 40,9 тыс. руб. до 43,0 тыс. руб.). При этом жители Республики Адыгея увеличили объем вкладов на сумму 0,7 млрд. руб., а общая задолженность населения перед банковским сектором выросла на 1,9 млрд. руб.

\section{ЛИТЕРАТУРА}

1. Глазьев, С.Ю. Развитие российской экономики в условиях глобальных технологических сдвигов: Научный доклад. - М.: НИР, 2014 - 219 с.

2. Галанов, В.А. Рынок ценных бумаг: Учеб. пособие для студентов вузов / В.А. Галанов, А.И. Басов // - М.: Финансы и статистика, 2014. - 276 с.

3. Дробозина, Л.А. Финансы. Денежное обращение. Кредит: учеб. пособие для студентов вузов. - М.: Инфра-М, 2014. - 248 с.

4. Айвазов, А.Л. Роль управления бюджетными средствами в денежно-кредитной политике Российской Федерации и перспективы ее развития [Электронный ресурс]. Режим доступа: https://e-koncept.ru/2016/56908.htm.

5. Мокрушин, А.А. Стратегические приоритеты развития региональных экономических систем // Вестник Адыгейского государственного университета. Серия 5: Экономика, 2010. № 3 - С. $102-105$.

6. Тамов, А.А. Методические аспекты оценки стратегического потенциала региональных среднесрочных программ // Вестник Адыгейского государственного университета. Серия 5: Экономика, 2010. №3. - С. 66-72. 


\title{
РОЛЬ ИПОТЕЧНОГО КРЕДИТОВАНИЯ В РАЗВИТИИ РЫНКА ЖИЛЬЯ РЕСПУБЛИКИ АДЫГЕЯ
}

Гидзова 3.А. Адыгейский государственный университет, г. Майкоп Научный руководитель: Мокрушин А.А., д.э.н., профессор, Адыгейский государственный университет, г. Майкоп

\begin{abstract}
Аннотация. В данной статье рассмотрена роль ипотечного кредитования в развитии рынка жилья в Республике Адыгея. Проведен комплексный анализ объема выданных ипотечных кредитов кредитными организачиями за 2013-2015 годы.

Ключевые слова: ипотечный кредит, процентная ставка, кредитные организации, рынок жилья.
\end{abstract}

\section{THE ROLE MORTGAGE LENDING IN THE HOUSING MARKET THE REPUBLIC OF ADYGEA}

Gidzova Z.A. Adyghe State University, Maikop Supervisor: Mokrushin A. A. PhD, Professor, Adyghe State University, Maikop

\begin{abstract}
This article considers the role of mortgage lending in the housing market of the Adygei Republic. The analysis of the volume of mortgage loans by credit institutions for 2012-2014.

Keywords: mortgage, interest rate, credit institutions, the housing market.
\end{abstract}

Под ипотечным кредитованием обычно понимается долгосрочный кредит, который может предоставляться банками физическому или юридическому лицу под залог недвижимого имущества, например, земли, жилых или производственных зданий, сооружений, помещений и т.д. В России самым доступным и распространенным вариантом использования ипотечного кредитования является покупка физическим лицом квартиры в кредит.

Ипотечное кредитование - это необходимый инструмент, благодаря которому жилье станется наиболее доступным для граждан страны. Основываясь на оценках представителей ведущих компаний коммерческой недвижимости, можно сделать вывод, что ипотечное кредитование используется при сделках в 40-70\% случаев.

Несмотря на значительное ухудшение макроэкономической ситуации на рынке и замедление темпов роста ипотеки, по данным ежеквартального отчета Агентства по ипотечному жилищному кредитованию, ипотечное жилищное кредитование остается одним из основных источников роста рынка жилья. Доля сделок с ипотекой выросла, основываясь на данных Росреестра, 27,8\% всех прав собственности, зарегистрированных в сделках с жильем в феврале-октябре 2015 года, приобреталось с помощью ипотечного кредита.

Таблица 1 - Объем ипотечного кредитования в РФ в 2013-2015z2.

\begin{tabular}{|l|l|l|l|l|l|}
\hline & I квартал & II квартал & III квартал & IV квартал & Итого \\
\hline 2015 & 335816 & 437837 & 498765 & 502432 & 1714850 \\
\hline 2014 & 322971 & 312319 & 343789 & 432187 & 1411266 \\
\hline 2013 & 186954 & 254767 & 287432 & 376322 & 1105475 \\
\hline
\end{tabular}


Из таблицы 1, где представляются данные по объему выдач ипотечных кредитов кредитными организациями Российской Федерации за 2013-2015 годы, видно, что рост объема предоставления ипотечных кредитов в четвертом квартале 2015 года по сравнению с аналогичным периодом 2013 года составил $33 \%$. Одной из причин роста ипотеки в 2014 году в основном объясняется тем, что в неблагополучных

условия $\mathrm{x}$ макроэкономической нестабильности, а так же ввиду снижения курса рубля, недвижимость стала популярным и надежным объектом для инвестиций. Огромное количество покупателей недвижимости видят в этом вложении защиту своих сбережений, либо стремятся приобрести квартиру для собственных нужд как можно скорее, опасаясь снижения доступности жилья в будущем.

По данным Аналитического Центра Русипотеки, была выявлена пятерка лидеров рынка ипотечного кредитования (таблица 2).

Таблица 2 - Состав участников рынка ипотечного кредитования РФ в 2013-2015z2.

\begin{tabular}{|c|c|c|c|c|c|}
\hline \multicolumn{2}{|c|}{ Итоги 2013 года } & \multicolumn{2}{|c|}{ Итоги 2014 года } & \multicolumn{2}{|c|}{ Итоги 2015 года } \\
\hline Банк & $\begin{array}{c}\text { Объем, } \\
\text { млн. руб. }\end{array}$ & Банк & $\begin{array}{l}\text { Объем, } \\
\text { млн. руб. }\end{array}$ & Банк & $\begin{array}{c}\text { Объем, } \\
\text { млн. руб. }\end{array}$ \\
\hline Сбербанк & 629761 & Сбербанк & 402000 & Сбербанк & 454786 \\
\hline ВТБ 24 & 243336 & ВТБ 24 & 157066 & ВТБ 24 & 165987 \\
\hline Минбанк & 78198 & Минбанк & 81332 & Минбанк & 90654 \\
\hline Россельхозбанк & 28135 & Россельхозбанк & 45988 & Россельхозбанк & 56986 \\
\hline
\end{tabular}

В таблице 3 представлены данные по объему 2015 годы, млн. руб. по данным Агентства по выданных ипотечных кредитов кредитными ипотечному кредитованию). организациями Республике Адыгея за 2013-

Таблица 3 -Объем ипотечного кредитования в Республике Адыгея в 2013-2015z2.

\begin{tabular}{|l|l|l|l|l|l|}
\hline & \multicolumn{1}{|c|}{ І квартал } & \multicolumn{1}{|c|}{ І квартал } & ІІ квартал & IV квартал & Итого \\
\hline 2015 & 65643 & 85143 & 92876 & 101654 & 345316 \\
\hline 2014 & 44654 & 60654 & 71534 & 83776 & 206618 \\
\hline 2013 & 34765 & 48765 & 52878 & 59764 & 196172 \\
\hline
\end{tabular}

Следует отметить значительный рост объема ипотечного кредитования в Республике Адыгея в 2015 году. При этом доля региона в общем объеме предоставления ипотечных кредитов в Российской Федерации составляет около 27\%. Средняя процентная ставка по ипотечным кредитам в 2015 году составляла $13,2 \%$, в 2014 году - 12\%, в 2013 году $-12,5 \%$. В большинстве своем наблюдается явная тенденция приобретения наиболее ликвидных квартир на рынке недвижимости Республики Адыгея. В 2014 году $34 \%$ от всех купленных в Республике Адыгее квартир составили однокомнатные квартиры. Увеличился спрос на студии: в 2014г. на их долю приходился 1\% от проданных квартир, в этом году уже 2\%; доля трехкомнатных и многокомнатных квартир сократилась. 
Вместе с тем, в 2015 году снизились темпы развития рынка жилья в Республике Адыгея и по стране в целом, что связано, в первую очередь, с высокой стоимостью кредитов и соответственно ограничением финансовых возможностей населения и строительных фирм. В 2014 году ставка по ипотечным кредитам в Республике Адыгея составляла $12 \%$, уже в феврале 2015 года ставка составляет $14,5 \%$ и колеблется до $23 \%$. При этом рост средней процентной ставки в Республике Адыгея за аналогичный период составил $56 \%$.

Таким образом, проведенный анализ роли ипотечного кредитования в развитии рынка жилья Республике Адыгея, свидетельствует о том, что, несмотря на рост объемов предоставления ипотечных кредитов, доступность

ипотечных

кредитов

значительно снижается. Следует отметить, что уровень развития ипотечного кредитования все еще достаточно низок (отношение ипотечного портфеля к ВВП находится около $3 \%$, а в развитых экономиках данный показатель достигает 100\% ВВП). Низкий уровень развития ипотечного кредитования в Республике Адыгея связан с достаточно высокими процентными ставками и малой долей граждан, уровень дохода которых позволил бы им производить ежемесячный платеж по ипотечному кредиту. Решение указанных проблем необходимо для развития рынка ипотечного кредитования Республики Адыгея в средне-, долгосрочной перспективе.

\section{ЛИТЕРАТУРА}

1. Пасик, В.И. Развитие ипотеки и рынка доступного жилья / В.И. Пасик, К.М. Ерошенков // Под ред. С.Г. Ерошенкова. - М.: МАКС Пресс, 2007. - 108 с.

2. Назарчук, Н.П. Ипотечное кредитование как инструмент решения жилищных проблем в Российской Федерации: монография. - Тамбов: Изд-во ФГБОУ ВПО «ТГТУ», 2014. - 152 c.

3. Тамов, А.А. Методические аспекты оценки стратегического потенциала региональных среднесрочных программ // Вестник Адыгейского государственного университета. Серия 5: Экономика. 2010. №3. - С. 66-72. 


\title{
СФЕРА УСЛУГ КРАСНОДАРСКОГО КРАЯ В УСЛОВИЯХ УХУДШЕНИЯ ОБЩЕЭКОНОМИЧЕСКОЙ КОНЪЮНКТУРЫ
}

Ковалева М.К. аспирант, Адыгейский государственный университет, г. Майкоп

Юрханян К.А. аспирант, Адыгейский государственный университет, г. Майкоп Научный руководитель: Захарова Е.Н. д.э.н., профессор, Адыгейский государственнылй университет, г. Майкоп

\begin{abstract}
Аннотация. Показано, что в условиях ухудиения общеэкономической конъюнктуры в Краснодарском крае довольно высокими темпами увеличивается вклад сферы услуг в региональный ВРП, происходящий, в основном, за счет роста объема бытовых и туристических услуг, услуг в области физической культуры и спорта, услуг связи. Обосновано положительное воздействие развития сферы услуг не только на экономические, но также на социальные и экологические параметры регионального развития.

Ключевые слова: сфера услуг, нестабильность внешней среды, экономическая конъюнктура, туристские услуги, устойчивое развитие региона.
\end{abstract}

\section{THE KRASNODAR REGION SERVICE INDUSTRY IN THE CONDITIONS OF GENERAL ECONOMIC CONJUNCTURE DETERIORATION}

Kovalyova M.K.

Post-Graduate Student, Adyghe State University, Maikop Yurkhanyan K.A.

Post-Graduate Student, Adyghe State University, Maikop Scientific Adviser: Zakharova E.N. Doctor of Economics, professor, Adyghe State University, Maikop

\begin{abstract}
The paper discloses quite rapidly increasing contribution of services industry in regional GRP in the conditions of general economic situation deterioration in the Krasnodar region. It occurs mainly due to growth in domestic and tourist services in the field of physical culture and sport services, communication services. The authors substantiate positive effects of service sector development, not only economic, but both social and environmental parameters of regional development.

Keywords: services industry, instability of the environment, economic environment, tourism services, sustainable development in the region.
\end{abstract}

Региональные рынки услуг в течение двух последних лет испытывают влияние негативных факторов, обусловленных ухудшением конъюнктуры внешних рынков и введением рядом государств экономических санкций в отношении Российской Федерации.

В частности, результаты конъюнктурных исследований, проведенных оценочной компанией «Эксперт» в предпринимательс ких структурах Краснодарского края, указывают на ключевые лимитирующие факторы, в значительной степени ограничивающие их эффективное развитие. К ним можно отнести высокий уровень налоговой нагрузки на бизнес, уменьшение уровня спроса на продукцию, относительное ухудшение макроэкономической ситуации и усложнение условий кредитования.

При этом результаты указанного исследования позволяют констатировать более низкий уровень снижения спроса на продукцию организаций сервисной сферы, по сравнению с динамикой спроса на продукцию производственных предприятий, ЧTO 
иллюстрируют данные, приведенные на рисунке 1 .

Кроме того, сфера услуг вносит все более значимый вклад в формирование ВРП Краснодарского края. Об этом свидетельствует тот факт, что за 10 лет с 2005 по 2014 год удельный вес отраслей, связанных с производством услуг в региональном ВРП возрос с 55 до $60 \%$.

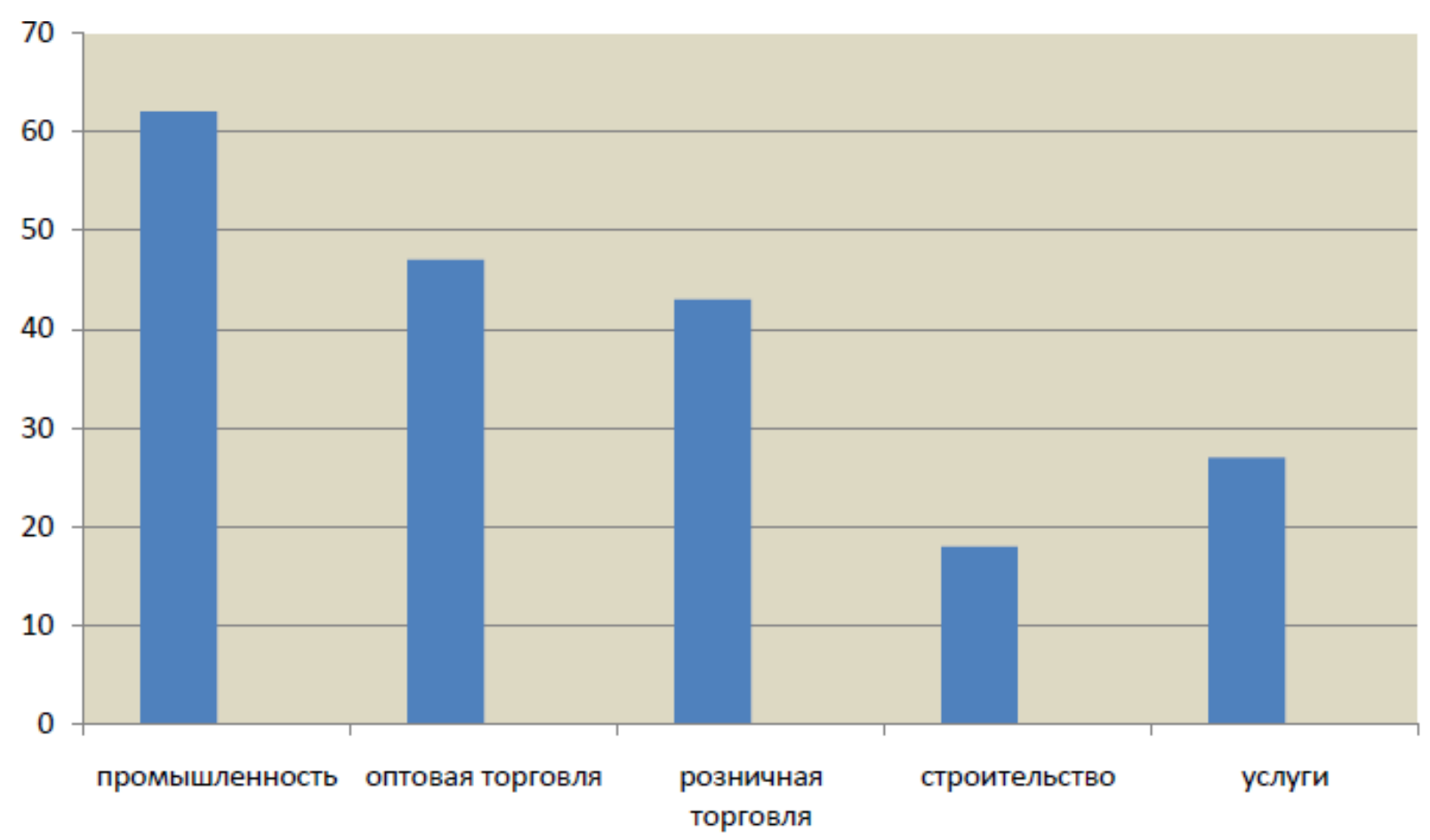

Рисунок 1 - Удельный вес экономических субъектов Краснодарского края, отметивших снижение спроса на их продукцию в условиях ухудиения общеэкономической конъюнктуры [3]

Необходимо указать на то, что секторбытовых услуг, объем производства которых в 2014 году вырос более, чем на 16\%, показал наивысший темп роста не только относительно других сегментов сервисной сферы региона, но и всех других секторов регионального хозяйства [2].

Кроме этого, достаточно высокие темпы роста объема услуг продемонстрировали сектора туристических услуг, услуг в области физической культуры и спорта, услуг связи. В данном контексте необходимо отметить, что уникальный природно-рекреационный потенциал края выступает в качестве одного из ключевых преимуществ, позволяющих обеспечить реализацию традиционных и инновационных направлений развития сферы рекреационно-туристических услуг в силу как снижения количества россиян, избирающих для себя отдых на зарубежных курортах, так и возможности задействования в туристических целях объектов, которые были возведены в рамках программы «олимпийского» строительства.

Величина инвестиционных вложений, направленных на развитие инфраструктуры Сочи в рамках подготовки к Зимним Олимпийским играм 2014 года, составила около 1,5 трлн. рублей. При этом было возведено 14 олимпийских объектов, которые в современных условиях можно использовать в круглогодичном режиме как в туристических целях, так и в рамках проведения самых разнообразных мероприятий делового, общественно-политического, культурного профиля. Помимо этого, их наличие сформировало основу для активного развития событийного туризма (российский этап «Формулы-1», матчи Чемпионата мира по 
футболу 2018 года, другие международные соревнования в зимних и летних видах спорта, Всемирный фестиваль молодежи и студентов 2017 года, концерты «звезд» мирового уровня, конкурсы, выставки и т.п.)

Строительство 46 гостиниц, насчитывающих 27 тысяч номеров и увеличение пропускной способности аэропорта в 2,5 раза позволяет добиться увеличения количества туристов, отдыхающих на Черноморском побережье Краснодарского края, на 10-15\%, что обеспечивает дополнительное приобретение ими товаров и услуг на сумму около 15 млрд. рублей в год и, как следствие, рост величины валового регионального продукта примерно на $5 \%$.

Осуществленные «олимпийские» инвестиции в значительной степени играют роль фундамента для поступательного развития сферы туристических услуг региона, которое в совокупности с реализацией программ в области обслуживания объектов «олимпийского наследия» может обеспечигь создание порядка 100 тысяч рабочих мест. В случае успешной реализации запланированных мероприятий указанного профиля прогнозируется увеличение налоговых поступлений в бюджеты различных уровней примерно на 6 млрд. рублей (из которых 3,5 млрд. руб. - налог на доходы физических лиц, 1,6 млрд. руб. - налог на прибыль и 0,9 млрд. руб. - налог на имущество). Помимо этого, увеличение бюджетных доходов за счет взимания арендной платы за землю в годовом исчислении составит 270 млн. рублей. Обозначенные налоговые и неналоговые поступления значительно превысят величину расходов, необходимых для содержания объектов «олимпийского наследия», составляющих ежегодно около 2 млрд. рублей.
Также следует отметить позитивную направленность воздействия мероприятий, связанных с развитием инфраструктуры сферы услуг на Черноморском побережье, в области улучшения экологической ситуации в регионе, проявляющуюся в следующем [1]:

1) строительство и реконструкция очистных сооружений позволила обеспечить переработку всего объема городских отходов одновременно с улучшением параметров качества очистки сточных вод;

2) возведение нового мусоросортировочного завода обеспечивает решение проблемы утилизации ТБО, возникшую в связис исчерпанием ресурсного потенциала городских свалок;

3) площадь особо охраняемых природных территорий должна быть увеличена на 20 тыс. гектаров.

Таким образом, проведенный анализ позволяет констатировать положительное воздействие развития сферы услуг не только на экономические, но также на экологические и социальные параметры регионального развития. Данное обстоятельство позволяет с полной уверенностью говорить об имеющемся потенциале развития сферы услуг в качестве инструмента обеспечения устойчивого развития региона, которое нацелено на решение триединой задачи, выражающейся в обеспечении экономической, социальной и экологической устойчивости, что имманентно предполагает реализацию мероприятиями, направленными на поддержку и стимулирование развития региональной сферы услуг, функций драйвера устойчивого развития региона в целом и воспроизводства человеческого капитала как важнейшей задачи данного развития, в частности. 


\section{ЛИТЕРАТУРА}

1. Сочи после Олимпиады: локомотив развития юга России [Электронный ресурс]. Режим доступа: http://www.basel.ru/highlights/pyat-klyuchevykh-napravleniypostolimpiyskogo-razvitiya-sochi.

2. Сфера бытовых услуг Кубани вырастет на кризисе [Электронный ресурс]. - Режим дос тупа: http://kuban.rbc.ru/krasnodar/11/02/2015/ 5592b42e9a7947e00d5b548a.

3. Ходзинская, А.Б. Адаптационный потенциал механизма развития региона в условиях дестабилизации экономической ситуации (на материалах Краснодарского края): дис. ... к.э.н. - Краснодар, 2015. - С. 98. 


\title{
ГОСУДАРСТВЕННО-ЧАСТНОЕ ПАРТНЕРСТВО, КАК НОВАЯ ФОРМА ВЗАИМООТНОШЕНИЯ ГОСУДАРСТВА И БИЗНЕСА
}

Кубашичев А.А. Магистрант 2 курса, Адыгейский государственный университет, г. Майкоп Научный руководитель: Хатукай С.A. к.э.н., доцент, Адыгейский государственный университет, г. Майкоп

Аннотация. В данной статье рассматривается государственно-частное партнерство, его формы и отличия от других видов отношений государства с частным сектором. Ключевые слова: Государственно-частное партнерство, государственная собственность, частный сектор.

\section{PUBLIC-PRIVATE PARTNERSHIP, A NEW FORM OF BUSINESS-GOVERNMENT RELATIONS}

Kubashichev A.A. Magistrant 2 course, Adygei state university, Maikop Research supervisor: Khatukay S.A. Cand.Econ.Sci., associate professor, Adygei state university, Maikop

\begin{abstract}
This article examines the public-private partnership, its forms and differences from other types of relations of the state with the private sector.

Keywords: Public-private partnership, public ownership, private sector.
\end{abstract}

В экономике применяется множество различных форм взаимодействия государства с субъектами предпринимательства. В последние годы в ряде развитых стран возникла особая форма подобного взаимодействия, которая получила название Public-Private Partnership (PPP). В российской терминологии эта форма имеет название «государственно-частное партнерств о » (ГЧП). ГЧП представляет собой партнерство государственной власти и частного бизнеса с целью реализации общественно значимых проектов в широком спектре сфер деятельности - от развития стратегически важных отраслей экономики до предоставления общественных услуг в масштабах всей страны или отдельных территорий. Активное изучение и выделение форм ГЧП во всех регионах мира, их широкое распространение во многих отраслях экономической деятельности дают возможность определять эту форму взаимодействия государства и бизнеса как характерную черту современной смешанной экономики.

В развитии ГЧП возникают отличия от традиционных форм отношений. В первую очередь возникают вопросы, связанные с перераспределением прав собственности. При этом права собственности распределяются между государством и бизнесом не полностью, а только по некоторым комплексам правомочий, например, право контроля над использованием активов, право на управление, право на доход, а также право на изменение капитальной стоимости объектов соглашений и право на переуступку тех или иных собственнических прав другим лицам.

Глобальный опыт перераспределения прав собственности между государством и частным бизнесом имеется в так называемых секторах общественных услуг. Именно там сложились тенденции передачи государством ряда важнейших прав частному сектору. Государство в рамках социальной политики 
обязуется

обеспечивать

населе ние

общественными благами (public goods), что и объясняет стремление к сохранению определенных отраслей и производств в собственности государства. В то же время к положительным и полезным свойствам предпринимательства

относятся

мобильность,

высокая эффективно с ть

использования имеющихся ресурсов, стремление к инновациям. Использовать преимущества обоих видов собственности без значительных социальных перемен и потрясений можно в рамках государственночастного партнерства.

ГЧП имеет ряд различных и специфических форм, таких как:

- $\quad$ государственные контракты (контракты на выполнение работ и оказание услуг, на управление собственностью государства, на поставку продукции для государственных нужд. В случае заключения такого контракта права собственности не передаются субъекту частного предпринимательства, расходы и риски полностью несет государство. Интерес частной стороны представляет право на оговариваемую долю в доходе, прибыли или собираемых платежах);

- apeндные отношения (особенность арендных соглашений между государственной властью и частным сектором заключается в том, частному партнеру передается государственное или муниципальное имущество во временное пользование и за определенную плату);

- финансовые аренды (лизинг) (в случае договора лизинга лизингополучатель имеет возможность покупки государственного или муниципального имущества. В мировой практике использование лизинговых форм партнерства органов местного самоуправления с субъектами частного предпринимательства имеют большое распространение); соглашения о разделе продукции (СРП) (такая форма отношений предполагает, что государство дает распоряжаться своей собственностью частной стороне соглашения, но в результате его использования, частному партнеру принадлежит только часть выпущенной продукции. Раздел продукции между государством и инвестором, его условия и порядок определяются в соглашении. В мировой практике соглашения о разделе продукции между государством и частным бизнесом активно используются в сфере нефтяного бизнеса);

- конщессионные соглашения (является специфической формой отношений между государством и частным партнером, набирающей популярность. Ее особенность заключается в том, что государство в рамках партнерских отношений, оставаясь полноправным собственником имущества, уполномочивает частного партнера выполнять в течение определенного срока определенные в соглашении функции и наделяет его с этой целью соответствующими правами. За пользование государственной или муниципальной собственностью частная сторона вносит плату на условиях, оговоренных в соглашении);

- государственно-частные предприятия (совместные предприятия являются распространенной формой партнерства государства и частного бизнеса. Это могут быть акционерные общества, либо совместные предприятия на долевом участии сторон. Отличительно й особенностью совместных предприятий любого типа является то, что государство постоянно участвует в текущей производственной, административно-хозяйственной и инвестиционной деятельности.

ГЧП имеет определенные черты, которые выделяют данное партнерство в самостоятельную экономическую категорию. Оглядываясь на страны с развитой рыночной экономикой, можно определить некоторые 
черты ГЧП, отличающие его от других форм отношений государственного и частного сектора:

- $\quad$ определенные сроки действия соглашений о партнерстве (от 10 - 15 до 20 и более лет, в случае концессий - до 50 лет). Проекты в большинстве случаев создаются под конкретный объект (дорога, социальный объект); - специфические формы финансирования проектов;

- обязательное наличие конкурентно й среды, когда за каждый контракт или концессию происходит борьба между несколькими потенциальными участниками;

\section{- $\quad$ разделение рисков между участни-} ками соглашения на основе соответствующих договоренностей сторон.

Средний показатель по уровню развития ГЧП в России по прогнозу на 2015 год должен был составить 29,2\%, фактическое среднее значение оказалось на $4,8 \%$ ниже и составило $24,4 \%$. Данную тенденцию можно объяснить следующими факторами:

- $\quad$ Ряд субъектов РФ по итогам 2015 года не показали ожидаемого роста реализации проектов ГЧП - планируемые проекты так и не были запущены;
- $\quad$ Регионы аутсайдеры не приняли базовых системных мер по созданию фундамента сферы ГЧП, о которых велась речь по итогам 2014 года;

- $\quad$ За счет снижения темпов роста российской экономики снизился интерес инвесторов к долгосрочным инвестициям в инфраструктуру на региональном и муниципальном уровне. Для повышения среднего общероссийского показателя по уровню развития ГЧП необходимо в первую очередь завершить на региональном уровне процесс приведения нормативно- правовой базы в соответствие с требованиями федерального закона о ГЧП и следующим шагом обеспечить поступательный запуск концессионных проектов и проектов ГЧП на региональном и муниципаль ном уровне.

Государство и частный сектор заинтересованы в успешном осуществлении проектов. Проекты ГЧП облегчают выход на мировые рынки капиталов, стимулируют привлечение иностранных инвестиций в реальный сектор экономики. Особое значение ГЧП имеет для экономики регионов, где на его основе развиваются местные рынки капитала, товаров и услуг.

\section{ЛИТЕРАТУРА}

1. Частно-государственное партнерство: состояние и перспективы развития в России: Аналитический доклад. - М.: Институт экономики РАН, Национальный инвестиционный совет, 2006. - С. 14.

2. Варнавский, В.Г. Государственно-частное партнерство: теория и практика / В.Г. Варнавский, А.В. Клименко, В.А. Королев и др. // Государственный университет, Высшая школа экономики. - М.: Изд. дом Государственного университета, Высшей школы экономики, 2010. - 287 с.

3. Корнеева, А.В. ГЧП в России: правовое регулирование, понятийный аппарат / А.В. Корнеева, А.А. Комиссаров // Вестник Калининградского филиала Санкт-Петербургского университета МВД России, 2013. No1. - 126-130.

4. Государство и бизнес: институциональные аспекты. - М.: ИМЭМО РАН - С. 40.

5. Керашев А.А. Потенциал государственно-частного партнерства в развитии взаимодействия вертикально-интегрированных корпораций с региональными экономическими системами России / А.А. Керашев, А.А. Мокрушин // Вестник Адыгейского государственного университета. Серия 5: Экономика, 2014. № 2(141). - С. 48-57. 
6. Мокрушин, А.А. Формы взаимодействия вертикально интегрированных корпораций с региональными экономическими системами Южного федерального округа // Региональная экономика: теория и практика. 2011. № 31. - С. 51-60.

7. Zakharova, E.N. Forms and Mechanisms of Public-Private Partnerships in Innovative Modernization of the Western Europe Economies / E.N. Zakharova, A.A. Mokrushin, A.R. Pshizova, S.A. Khatukay, S.K. Chinazirova // Asian Social Science, 2015. T. 11. №21. - C. 321-330. 


\title{
ГОСУДАРСТВЕННО-ЧАСТНОЕ ПАРТНЕРСТВО В РЕСПУБЛИКЕ АДЫГЕЯ
}

Кубашичев А.А.

Магистрант 2 курса, Адыгейский государственный университет, г. Майкоп

Научный руководитель: Хатукай C.A. к.э.н., доцент, Адыгейский государственный университет, г. Майкоп

\begin{abstract}
Аннотация. В данной статье рассматривается текущая ситуация с развитием форм и принятием проектов государственно-частного партнерства на территории Республики Адыгея.

Ключевые слова: Государственно-частное партнерство, Республика Адыгея, инвестиционный климат, инвестиционный проект.
\end{abstract}

PUBLIC-PRIVATE PARTNERSHIP IN THE REPUBLIC OF ADYGEA

Kubashichev A.A.

Magistrant 2 course, Adygei state university, Maikop

Research supervisor: Khatukay S.A.

Cand.Econ.Sci., associate professor, Adygei state university, Maikop

\begin{abstract}
This article examines the public-private partnership, its forms and differences from other types of relations of the state with the private sector.

Keywords: Public-private partnership, public ownership, private sector.
\end{abstract}

На данном этапе развития экономики Российской Федерации, большое значение имеет развитие государственно-частного партнерства в регионах РФ. Республика Адыгея не является исключением и развивается в этом направлении. Уже в 2012 году Государственным Советом - Хасэ Республики Адыгея был принят закон о государственной политике Республики Адыгея в сфере государственночастного партнерства. Согласно принятому закону , целью государственно-частного партнерства является объединение материальных, финансовых и организационных ресурсов, а также привлечение средств внебюджетных источников для реализации общественно значимых проектов и программ в социально-экономической сфере на территории Республики Адыгея с использованием средств республиканского бюджета Республики Адыгея и (или) имущества, находящегося в государственной собственности Республики Адыгея.

А задачами государственно-частного партнерства являются:
- привлечение внебюджетного финанс ирования для реализации общественно значимых проектов;

- повышение эффективности использования государственного имущества Республики Адыгея;

- эффективное использование средств республиканского бюджета Республики Адыгея;

- развитие инновационной экономики, техническое и технологическое развитие общественно значимых производств;

- повышение уровня занятости населения.

Региональные и муниципальные нормативно-правовые акты, регламентирующие порядок работы с проектами ГЧП в республике отсутствуют.

Отсутствие необходимой институциональной среды негативно влияет на перспективы привлечения инвестиций в проекты ГЧП. 
Таблица 1 - Число инвестиционных проектов, реализуемых в рамках ГЧП

\begin{tabular}{|c|c|c|c|c|c|c|}
\hline & 2009 & 2010 & 2011 & 2012 & 2013 & 2014 \\
\hline $\begin{array}{c}\text { Число инвестицио нных проектов, } \\
\text { реализуемых в рамках ГЧП, ед. }\end{array}$ & - & 1 & - & 2 & 1 & 0 \\
\hline
\end{tabular}

В Республике Адыгея в рамках реализации Федеральных целевых программ применяется метод государственно-частного партнерства, при котором за счет бюджетных средств осуществляется строительство инфраструктурных объектов в энергетической и транспортной сфере, а за счет внебюджетных источников - строительство объектов бизнеса, прино сящих доход.

В республике отсутствует опыт реализации проектов ГЧП в социальной (здравоохранение, образование, спорт, туризм, культура, социальное обслуживание) и коммунально й сферах, в то время как в регионах России в этих отраслях реализуется более $61 \%$ проектов ГЧП.

Так как инвестиционный климат в Республике не самый приятный, соответственно показывать высокие показатели развитости ГЧП, является тяжелой задачей, с которой на данный момент правительство Республики Адыгея не справляется. Если опираться на вышеуказанный рейтинг, составленный Министерством экономического развития РФ, то становиться ясно, что рассматриваемый субъект РФ находиться в неприятно й ситуации.

При проведении анализа динамики развития ГЧП в Адыгее, мы видим, что в 2012 году Республика Адыгея занимала 78 место из 83( на тот момент ) субъектов РФ. В Республике было незначительный проект, основанный на государственно-частном партнерстве. В 2013 же году ситуация заметно улучшилась и Адыгея заняла по итогам года
47 место. Это означало, что государственно частное партнерство характеризуется стадией формирования первичного опыта, но при этом создаются условия для гармоничного развития механизмов ГЧП. В основном здесь представлены регионы, в которых проекты ГЧП находятся еще на прединвестиционно й стадии, а также регионы, в которых усилиями администраций создаются условия для привлечения частного инвестора.

Согласно Рейтингу регионов России по уровню развития государственно-частного партнерства 2014/2015, проведенному Центром развития государственно-частного партнерства, Республика Адыгея отнесена к группе регионов с очень низким уровнем развития ГЧП и находится на 84 месте. Позиция республики снизилась по сравнению с 2013 годом на 37 пунктов, на что в большей части повлияло введение экспертных коэффициентов и исключение булевого подсчета в части уровня развития институциональной среды.

Целевое значение показателя по уровню развития ГЧП, установленное для Республики Адыгея Распоряжением Правительства Российской Федерации № 570-p не достигнуто (факт - 8,8\%; план - 29\%).

Одной из основных причин является, что фактические и целевые значения уровня развития государственно-частного партнерства в регионах, установленные в Распоряжении Правительства РФ № 570-p, изначально рассчитывались в соответствии с методикой, не предусматриваю ще й дополнительную (корректирующую) 
экспертную оценку, основываясь только на булевых показателях (да / нет), что привело к завышению начального уровня развития государственно-частного партнёрства в республике и чрезмерно оптимистичным ожиданиям по дальнейшему улучшению показателя в 2014 году.

Таким образом, задача «Развитие института государственно-частного партнерства» в 2014 году реализовывалась неэффективно.

В мае 2015 года на территории Республики Адыгея был открыт мясоперерабатывающий комплекс $3 \mathrm{AO}$ «Киево-Жураки АПК», который является одним из ведущих предприятий республики по производству мяса свинины. Мясоперерабатывающий комплекс с производственной мощностью от 500 до 700 голов в смену. Он построен по всем современным стандартам и санитарным нормам, оснащен передовым импортным оборудованием и состоит из разделочного, холодильного, сырьевого цехов и конвейера шокового охлаждения.

Основным направлением деятельности является первичная и глубокая мясопереработка. Здесь трудоустроено около 100 человек со средней зарплатой около 20 тыс. рублей, а ежегодные налоговые отчисления компании составляют около 30 млн.рублей.

Предприятие было образовано в 2006 году. В Адыгее реализует инвестиционный проект уже 7 лет, успешно развивается и наращивает объемы производства продукции. Для обеспечения собственной кормовой базы $3 \mathrm{AO}$ «Киево-Жураки АПК» имеет в долгосрочной аренде 5 тыс. га пахотной земли.

Сегодня на ЗАО «Киево-Жураки АПК» насчитывается около 5 тыс. голов свиноматок при производительности поросят 25 голов на 1 свиноматку в год. Ежегодно реализуется 110 тыс. голов или 10 тыс. тонн мяса в живом весе. Всего же в республике производится в среднем около 47 тыс. тонн мяса в год.
Реализация в республике крупно го инвестиционного проекта компании «КиевоЖураки» - это еще один серьезный шаг на пути к обеспечению продовольственной безопасности Адыгеи и пример эффективной реализации в республике инвестиционной политики. Проект реализован с использованием механизма государственно частного партнерства. Госсредства были направлены на создание части инженерной инфраструктуры объекта. На создание комплекса затрачено более полумиллиарда рублей инвестиций, в том числе - кредитные средства ОАО «Россельхозбанк» в размере более трёхсот миллионов рублей.

Руководство Адыгеи связывает свои ожидания по увеличению производства мяса в республике именно с ЗАО «Киево-Жураки АПК». В дальнейшем компания намерена развивать производство и расширять ассортимент выпускаемой готовой продукции, которую поставляет в разные регионы России, в Майкопе реализует мясо свинины на ярмарках выходного дня и через фирменный магазин. В ближайших планах строительство еще двух торговых предприятий в республиканской столище и одного в п. Яблоновский.

На данный момент в Республике идет процесс актуализации стратегии развития региона, на инвестиционном форуме «Сочи2016» был подписан ряд соглашений по реализации инвестиционных проектов на территории Республики Адыгея из этого можно сделать вывод, что принимаются меры по улучшению инвестиционного климата и более глубокому и эффективному использованию государственно-частного партнерства в Республике Адыгея. Правительство Республики использует как финансовые механизмы поддержки, так и нефинансовые, но, к сожалению, на сегодняшний день эти меры не приносят 
ожидаемого эффекта. В условиях кризиса предпринимаемых мер, мы в праве тяжело рассчитывать на быстрый темп роста рассчитывать на достижение успешных экономики Адыгеи, но с учетом результатов в долгосрочной перспективе.

\section{ЛИТЕРАТУРА}

1.Акинина, В.П. Государственно-частное партнерство как катализатор инновацио нных процессов / В.П. Акинина, Р.Г. Абасов // Финансы и кредит, 2013. No9.- С. 45 50 .

2. Государственно-частное партнерство: теория и практика / В.Г. Варнавский, А.В. Клименко, В.А. Королев и др. // Государственный университет, Высшая школа экономики. - М.: Изд. дом Государственного университета, Высшей школы экономики, 2010. - 287 с.

3. Корнеева, А.В. ГЧП в России: правовое регулирование, понятийный аппарат / А.В. Корнеева, А.А. Комиссаров // Вестник Калининградского филиала Санкт-Петербургского университета МВД России, 2013. No1. - С. 126-130.

4. Мошкова, Л.Е. Стратегии развития государственного управления и партнерские отношения бизнеса и власти на территории присутствия // Вестник Тверского государственного университета. Серия Экономика и управление, 2014. No2. - С. 361-372.

5. Zakharova, E.N. Forms and Mechanisms of Public-Private Partnerships in Innovative Modernization of the Western Europe Economies / E.N. Zakharova, A.A. Mokrushin, A.R. Pshizova, S.A. Khatukay, S.K. Chinazirova // Asian Social Science, 2015. T. 11. № 21. - C. 321-330.

6. Мокрушин/ А.А. Корпоративное управление интеграционными трансакциями в АПК региона: функциональные особенности, критерии эффективности / А.А. Мокрушин, С.В. Кесян // Новые технологии, 2013. №4. - С. 61-67. 


\title{
СЕТЕВОЙ ФОРМАТ КАК ИНСТРУМЕНТ ОБЕСПЕЧЕНИЯ УСТОЙЧИВОСТИ ТОРГОВОГО БИЗНЕСА В УСЛОВИЯХ НЕСТАБИЛЬНОЙ ВНЕШНЕЙ СРЕДЫ
}

Мамсирова А. $A$. аспирант, Адыгейский государственный университет, Россия, г. Майкоп

\begin{abstract}
Аннотация. В статье рассматриваются преимущества обеспечения устойчивости торговых предприятий в рамках сетевой формы организации их деятельности. Обуславливается необходимость ориентащии прочесса обеспечения устойчивости торговой сети как на преодоление негативных тенденций внешней среды, таки на создание задела для успешного развития в условиях экономического роста.

Ключевые слова: устойчивость, волатильность, услуги торговли, торговая сеть.
\end{abstract}

\section{NETWORK FORMAT AS A TOOL OF TRADING BUSINESS SUSTAINABILITY IN UNSTABLE ENVIRONMENT}

Mamsirova A.A. Post-Graduate student, Adyghe State University, Russia, Maikop

\begin{abstract}
This paper considers the advantages of ensuring the of commercial enterprises sustainability in the conditions of network forms of their activities organizations. The author substantiates the need of the orientation process to overcome the negative trends in the external environment as well as to create a reserve for the successful development of economic growth.

Keywords: stability, volatility, trading services, trading network.
\end{abstract}

Одной из ключевых характеристик процесса функционирования торговых организаций в современных условиях является постоянное возрастание нестабильности внешней среды их деятельности, а также усложнение проявлений воздействия ее факторов. При этом внешняя среда организации определяется как совокупность объектов, находящихся вне пределов данной структуры, изменение важнейших свойств которых может обусловить трансформацию ее состояния [1, с. 180].

В нестабильной внешней среде неопределенность является имманентно присущей процессу торговой деятельности характеристикой, так как не представляется возможным с достаточно высоким уровнем точности спрогнозировать направленнос ть тенденций развития ключевых рыночных факторов, оказывающих непосредственное влияние на функционирование торговой организации. Кроме того, построение механизма обеспечения устойчивости отдельного торгового предприятия является довольно сложным процессом, что обусловлено комплексом следующих обстоятельств [3, с. 48]:

- формирование механизма обеспечения устойчивости развития предприятия зачастую обусловливает нарушение симметрии его временной и пространственной структуры, в результате чего довольно незначительные изменения во внешней среде производят разрушительный эффект в отношении бизнес-структуры;

- абсолютно устойчивым (либо неустойчивым) предприятие может быть только в исключительных случаях, в реальности же предприятие устойчиво либо неустойчиво по отношению к конкретным условиям внешней среды;

- усложнение и системность воздействия внешних факторов на деятельность предприятия увеличивает количество угроз его экономической устойчивости, в результате чего от- 
носительно стабильное существование предприятия подвергается практически постоянному негативному воздействию этих факторов;

- механизм обеспечения экономической устойчивости по своей природе близок к дисипативным структурам и довольно трудно управляем при помощи административ ных методов;

- процесс управления экономической устойчивостью, уровень которой далек от состояния равновесия, предполагает использование более тонких методов управления, которые, как правило, характеризуются предельными эффектами.

Именно поэтому активное развитие торговых сетей можно рассматривать как способ оптимизации бизнеса и получения экономии от масштаба деятельности в контексте повышения степени его устойчивости, поэтому преимущества торговых сетей во многом схожи с преимуществами крупного бизнеса, более устойчивого к проявлениям волатильности внешней среды.

Отметим, что в сетевой структуре происходит замена иерархических принципов построения на гетерархические. Кроме того, для сетевой структуры характерен переход от прямой адаптации к определенному состоянию к расширенному набору средств организации деятельности в изменяющейся внешней среде. При этом она способна эволюционировать с одной стороны путем изменения своей внутренней структуры, а с другой - через оказание воздействия на внешнюю среду, направленность которого обуславливается целевыми ориентирами, имеющимися у компании сетевой торговли.

В число инструментов обеспечения устойчивости предприятия сетевой торговли входит большое количество взаимосвязанных средств, при помощи которых обеспечивается достижение

целевых

ориентиров,

отражающих устойчивость развития бизнеса. К основным из данных инструментов специалисты относят[2, с. 65]:

- резервы, имеющиеся в распоряжении компании сетевой торговли;

- средства мониторинга и анализа важнейших параметров функционирования компании;

- инструменты диверсификации деятельности торговой сети и развития конкурентных отношений в рамках ее внутренней среды;

- инструменты формирования позитивного имиджа и повышения инвестиционной привлекательности сети.

Следует отметить, что определение используемых инструментов обеспечения устойчивости сетевой компании базируется на оценке соответствия данных инструментов сложившейся ситуации, выявлении наиболее проблемных участков деятельности в рамках сети, учете специфики факторов территориального развития предприятий, входящих в сеть, и т.д.

Необходимо отметить, что наиболее устойчивыми торговыми сетями являются компании, которые стандартизировали все бизнес-процессы, выстроили разветвленную систему распределительных центров, обладают собственным парком грузовых автомобилей, осуществили централизацию большинства управленческих функций, разработали успешную кадровую политику, построенную на мотивации персонала и подготовке руководителей внутри коллектива, сформировали детальные планы перспективного развития компании.

При этом одним из крайне актуальных в рамках текущего положения дел инструментов обеспечения устойчивости предприятий сетевой торговли выступает формирование таких характеристик процесса функционирования торговой сети, которые 
могут обеспечить достижение выгодной природе является многоцелевым, потому как конкурентной позиции компании как при устойчивость сети как системы ухудшении конъюнктуры вследствие обусловливается совокупностью продолжающегося негативного воздействия компонентов, каждый из которых должен факторов внешней нестабильности, так и в подвергаться определенному воздействию перспективной ситуации экономического роста.

Таким образом, подобное управление для того, чтобы обеспечивать соответствие состояния системы требованиям поддержания устойчивостью сетевой компании по своей устойчивости в настоящем и будущем.

\section{ЛИТЕРАТУРА:}

1. Нагорянская, Н. В. Основы формирования адаптивного управления промышленным предприятием // Экономика строительства и городского хозяйства, 2008. Т.2. № 3. C. 180 .

2. Семин, А.А. Устойчивость развития сетевого бизнеса и его социальная ответственность в условиях внешней нестабильности // Вестник Ростовского государственного экономического университета (РИНХ), 2016. № 2. - С. 65.

3. Шовкопляс, А.Ш. Концепция формирования механизма обеспечения экономической устойчивости предприятия //Экономинфо, 2015. № 23. - С. 48-52. 


\title{
АКТУАЛЬНЫЕ ВОПРОСЫ СОВЕРШЕНСТВОВАНИЯ РЕКЛАМНОЙ КОМПАНИИ ПРИМЕНИТЕЛЬНО К ООО «МПК» ПИВОВАРЕННЫЙ ЗАВОД «МАЙКОПСКИЙ»
}

Оганнисян М.А. студент Экономического факультета; Адыгейский государственный университет, г. Майкоп

Хатукай C.A. к.э.н., дочент кафедры Экономики и управления; Адыгейский государственный университет, г. Майкоп

\begin{abstract}
Аннотация. В статье приведень рекомендации по организации рекламной кампании предприяти ООО «МПК» Пивоваренный завод «Майкопский» с учётом действующего законодательства и опыта рекламы крупных компаний-конкурентов. Раскрыты тонкости продвижения товарной марки организаџии.

Ключевые слова: реклама, интернет-реклама, имиджевая реклама, организачия рекламной деятельности.
\end{abstract}

\section{CURRENT ISSUES IN IMPROVEMENT OF ADVERTISING IN RESPECT OF OOO "IPC" BREWERY "MAIKOP"}

Ogannisyan M.A. student of the Faculty of Economics; Adyghe State University, Maikop Khatukai S.A. k.e.n., Associate Professor, Department of Economics and Management; Adyghe State University, Maikop

\begin{abstract}
The article provides recommendations on the organization of the advertising campaign of the enterprise LLC "IPC" Brewery "Maikop", taking into account the current legislation and advertising experience large competing companies. Reveals the intricacies of promoting brand image of the organization.

Keywords: advertising, online advertising, image advertising, the organization of promotional activities.
\end{abstract}

Самые простые формы рекламы брали своё начало ещё задолго до нашей эры. Одним из древнейших рекламных обращений, дошедших до нашего времени считается египетский папирус, на котором размещались объявления о продаже рабов. Наибольшее распространение в древнее время имели надписи, нацарапанные или начертанные краской на камнях. В древнем Риме и Греции первые рекламные объявления писались на досках или гравировали на костях, после чего, громко зачитывали на площадях и других местах массового скопления людей.

На сегодняшний день рекламный рынок это очень важная сфера экономики практически каждой страны, которая обеспечивает большое количество населения рабочими местами. Кроме того, стоит учитывать, что рекламный рынок - одна из наиболее динамично развивающихся сфер рынка во всём мире. Использование такого механизма рекламы, как средства массовой информации для распространения рекламы даёт возможность достичь неконтролируемое, никакими факторами, воздействие на широкие массы людей.

Актуальность исследования данной темы неоспорима, так как правильная организация рекламной компании позволяет достичь максимального эффекта и распростране ния 
узнаваемости товара или бренда в целом.

\section{В различных источниках существует}

большое количество определения рекламы, но, помимо этого, существует официаль ное определение рекламы, которое дано в Федеральном законе Российской Федерации «О рекламе» от 13 марта 2006 года №38-Ф3 (редакция от 27.09.2009 г. №228-Ф3 РФ).

Реклама - информация, распространяемая любым способом, а также, в любой форме и с использованием любых

средств

распростране ния, которая

адресована неопределенному кругу лиц и направленная на привлечение внимания к объекту рекламирования (товару, товарному знаку, организации и др.), формирование или поддержание интереса к нему и его активное продвижение на рынке[1].

В данный момент на рынке рекламы можно заметить большое многообразие форм рекламных компаний.

Учитывая все тонкости организации рекламной кампании, можно сделать вывод, что реклама - это сложный процесс, который требует глубокого анализа. На рынке можно встретить большое многообразие рекламы, начиная от билбордов и печатных изданий, заканчивая рекламой, интегрированной в мобильные приложения и СМС-рассылками.

В качестве объекта данного исследования была выбрана организация, занимающаяся производством и реализацией алкогольной и безалкогольной продукции ООО «МПК» Пивоваренный завод «Майкопский». Особый интерес вызвал вопрос разработки рекламной компании для данного предприятия, поскольку продукция, производимая им, попадает под определённые ограничения в рекламной деятельности, закреплённые в Федеральном Законе РФ.

В данном научном исследовании были рассмотрены проблемы и тонкости организации рекламы для предприятия, занимающегося производством алкогольной продукции.

Анализируя организацию рекламной кампании на примере ООО «МПК» Пивоваренный завод «Майкопский», стоит учитывать, что основным товаром компании является пивоваренная продукция, поэтому необходимо учитывать следующие особенности продвижения алкогольной продукции на рынок и помнить, что существуют законодательные ограничения, в связи с которыми реклама пива не должна:

- Содержать всяческие убеждения о том, что употребление алкогольной продукции имеет необходимое значение для достижения профессионального, личного или спортивного успеха;

- Осуждать лиц, принявших решение воздержаться от употребления алкогольной продукции;

- Обращаться к несовершеннолетним лицам;

- Содержать в себе утверждения о том, что алкогольная продукция является безвредной или полезной для употребления;

- Использовать образы людей и животных (в том числе, анимационные);

Также стоит учитывать, что, в соответствии со статьёй 21 частью 3, предлагается использовать рекламные объявления с обязательной предупредительной надписью о вреде чрезмерного употребления алкогольных напитков. Если речь идёт о рекламном ролике, то данная информация должна занимать $10 \%$ экрана и должна присутствовать на протяжении всего видео ролика. Если рассматривать рекламное объявление, то сообщение о вреде алкоголя должно занимать не менее $10 \%$ от общего пространства баннера, вывески или иного разрешённого законом способа отображения рекламы алкогольной продукции. 
Помимо этого, запрещается рекламировать продукцию алкогольного типа на первой и последней страницах журналов и газет (так же на обложке), в изданиях, предназначенных для несовершеннолетних, в детских и образовательных учреждениях и т.д. Кроме того, определенные

ограничения применяются и к местам продаж алкогольной продукции. Так, закон о продаже пива гласит, что не допускается розничная продажа алкогольной продукции в нестационарных торговых объектах (это временное сооружение, на которое не возможно зарегистрировать право собственн ости, к примеру: киоск, ларек (палатка), павильон, прилавок). Общая площадь таких помещений должна составлять не менее 50 квадратных метров (в сельских поселениях не менее 25 кв. м). Все эти ограничения значительно осложняет вопросы обеспечения стабильного сбыта продукции и компании необходимо искать пути увеличения сбыта продукции, в чем призвана помогать реклама.

Компаниям-про изводителям стоить всегда помнить и учитывать данные ограничения при организации рекламы своей продукции, потому что нарушение данных законов влечёт за собой материальные последствия, а также потерю имиджевой составляющей предприятия. Рассмотрим несколько примеров успешной и провальной рекламной компании.

Так, «Пивоваренная компания «Балтика» была оштрафована за размещение рекламного объявления на обложке собственного корпоративного журнала «Моя Балтика» иллюстрации с бутылкой алкогольной продукции. Штраф составил 101 тыс. рублей. Соответственно, можно сделать вывод, что если бы компания в своём рекламном объявлении использовала товарный знак «Балтики» и отказалась от изображения пивоваренной продукции, то смогла бы избежать данного инцидента.

Одним из самых успешных примеров организации маркетинговой кампании является реклама бренда «Miller Lite», который в 1974 году создав абсолютно новый продукт на рынке, совершили настоящий маркетинговый прорыв. Компания представила потребителям лёгкое светлое пиво, тем самым фактически захватив новый рынок. Слоган «Больше вкуса, меньше градусов» в телевизионных роликах и на плакатах вещали американские символы мужественности. Тем самым, у потребителей выстраивался образ «крутого» мужчины, пьющего пиво «Miller Lite». Компания достигла оглушительного успеха и уже на протяжении более сорока лет ей удаётся поддерживать свой имидж и являться лидерами данного рынка.

Если рассматривать пример успешно построенной современной рекламы пивоваренной продукции, то следует отметить креативную рекламную кампанию пива «Балтика» для чемпионата России по футболу, разработанную агентством Debby. B основу проекта была взята «синяя карточка». Рекламное агентство создало три видеоролика с использованием этой карточки. Бренд компании «Балтика» занимал всё пространство символа рекламы - синей карточки (Рисунок 1). Руководство фирмы «Балтика» добилось желанного результата и повысило узнаваемость своего бренда.

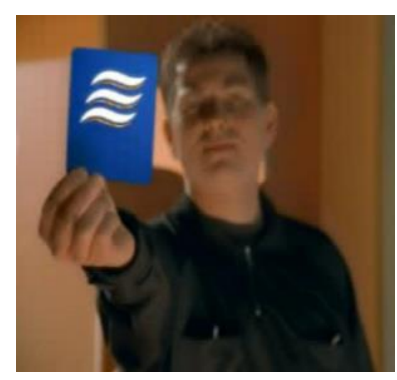

Рисунок 1. Рекламная компании "Балтики», выполненная агентством Debby. 
Также, в марте 2016 года «Балтика» присоединилась к инициативе рекламы безалкогольного пива, что значительно увеличило потребительскую базу организации.

Однако, стоит учитывать так же тот факт, что реклама пива не запрещена, а лишь ограничена некоторыми законами. Поэтому, будет уместно проанализировать и рассмотреть более подробно способы рекламы алкогольной продукции, а именно пивоваренной, в рамах Законодательства РФ. Рассмотрим более подробно некоторые из них.

В печатных средствах массовой информации допускается размещение рекламы алкогольной продукции за исключением первой и последний полос газетных изданий, а также первой и последней страниц журнальных обложек. Данное правило не распространяется на детские издания. Подобная реклама на них строго запрещена.

Законодательство

не

запрещае т распространение рекламы пивоваренно й продукции во время проведения трансляций в прямом эфире и записи спортивных состязаний (матчей, игр, гонок, боёв). Так же, не распространяется на детско-юношеские спортивные соревнования.

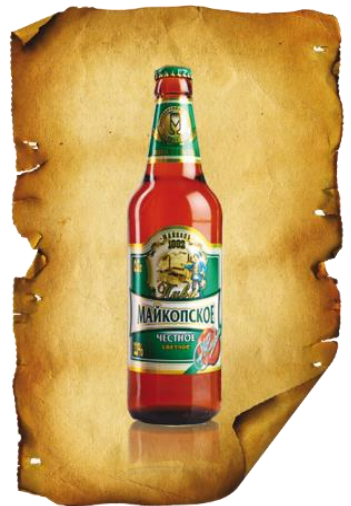

Рисунок 2.
Размещение рекламы также допускается в спортивных сооружениях и на расстоянии 100 метров от них. Допускается размещение и распространение средств индивидуализации товарной продукции в виде словесных обозначений. При размещении подобного типа рекламы, стоит учитывать правки, внесённые Федеральной антимонопольной службой. ФАС указывает, что реклама пива:

- Должна быть выражена исключитель но в словесной форме;

- $\mathrm{He}$ должна содержать изображения пива и слоганы, призывающие к покупке данного продукта.

На наш взгляд, анализ ируемому предприятию необходимо использовать все разрешенные способы и рекламы и, помимо этого, сделать акцент на имиджевой рекламе, тем самым продвигая и укрепляя позиции "имени" завода на современном рынке.

Учитывая все вышеперечисленное и проведённое нами исследование, мы можем предложить предприятию ООО «МПК» Пивоваренный завод «Майкопский» в рамках своей рекламной кампании использовать размещение рекламных объявлений с использованием логотипа. Ниже представлены примеры «правильной» и «неправильной» рекламы пивоваренной продукции.

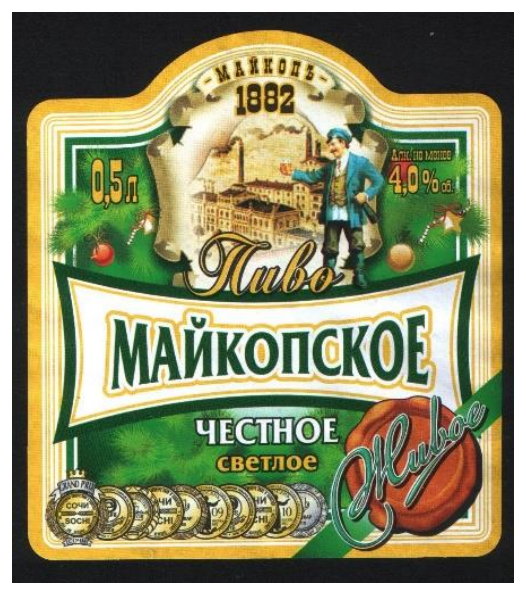

Рисунок 3. 
На Рисунке 2 ярко выражена алкогольная продукция, что напрямую противоречит действующему законодательству. Рисунок 3 отражает лишь название и не содержит в себе изображения пива, поэтому данное изображение можно использовать в рамках рекламы.

Также, на наш взгляд, успешным ходом для предприятия будет проведение дня открытых дверей, на которых потенциальные потребители будут иметь возможность напрямую познакомиться со всей, предоставляемой продукцией. $\mathrm{Ha}$ мероприятиях подобного плана у руководства организации появляется возможность получения обратной связи от потребителей.

В настоящее время Интернет активно развивается как рекламный канал. С середины 2000-х годов Интернет считается одним из основных каналов информационного воздействия на потребителей. Это связано, прежде всего, со следующими факторами: постоянным и устойчивым ростом числа интернет-пользователей и времени их нахождения в сети; развитием технологий беспроводной связи, мобильных устройств и мобильного Интернета; развитием интернет-экономики и, прежде всего, широким распространением интернетторговли. Поэтому, следующим успешным инструментом продвижения торговой марки
Пивоваренного Завода «Майкопский» может являться реклама в интернете, а именно, правильная настройка контекстной рекламы. Данный вид рекламы позволяет осуществлять показ рекламы в зависимости от содержания сайта. [3]

Помимо всего вышесказанного, следует помнить, в ООО «МПК» Пивоваренный завод «Майкопский» также налажено производство безалкогольной продукции. На сегодня производятся следующие 7 видов : «Майкопская Груша», «Майкопская КремСода», «Майкопский Тархун», «Майкопский Лимонад», «Майкопский Буратишка», «Майкопская Вишня», «Майкопский Колокольчик». Так же, с 2010 года началось производство питьевой воды «AQUAФИШТ», благодаря которой завод стал лауреатом Всероссийского конкурса Программы «100 лучших товаров России». Таким образом, необходимо активно рекламировать данные виды изделий, для того, чтобы имя компании стало узнаваемым и было всегда на слуху потребителей. Благодаря достижениям подобного типа у предприятия есть возможность продвижение собственного товарного знака, что повлечёт за собой повышение узнаваемости бренда ООО «МПК» Пивоваренный завод «Майкопский».

\section{ЛИТЕРАТУРА}

1.Федеральном законе РФ «о рекламе» от 13 марта 2006 года №38-Ф3 (в ред. от 27.09.2009 Г. №228-Ф3).

2. Кумпилова Б.А. Актуальные вопросы маркетинга на современном этапе. Учебное пособие / Б. А. Кумпилова, С.А. Хатукай // - Майкоп: изд-во АГУ, 2016. - 236 с.

3. Оганнисян, М.А. Современные методы рекламы в интернете / М.А. Оганнисян, C.А. Хатукай // Сборник научных трудов по материалам III Международной научно практической конференции - Экономика и управление в современных условиях: проблемы и перспективы, 2016 - С. 48-52. 


\title{
ПРОБЛЕМЫ И ПЕРСПЕКТИВЫ РАЗВИТИЯ РЫНКА МОБИЛЬНОГО
} МАРКЕТИНГА В РОССИИ

Оганнисян М.А. Адыгейский государственньий университет, г. Майкоп Научный руководитель: Мокрушин $\boldsymbol{A}$.A. д.э.н., профессор, Адыгейский государственный университет, г. Майкоп

Аннотация: В данной статье раскрыта роль мобильного маркетинга в современном бизнесе, приведены примеры организации эффективного мобильного маркетинга. Раскрыт потенциал мобильного маркетинга в развитии коммерческой деятельности компаний в условиях роста объема потребляемого контента.

Ключевые слова: мобильный маркетинг, реклама, продвижение, иеелевой рынок.

\section{PROBLEMS AND PROSPECTS OF DEVELOPMENT OF THE MOBILE MARKETING MARKET IN RUSSIA}

Ogannisyan M.A. Adyghe State University, Maikop Research supervisor: Mokrushin A.A. Doctor of Economics, professor, Adyghe State University, Maikop

\begin{abstract}
This article reveals the role of mobile marketing in modern business, examples of effective mobile marketing. The potential of mobile marketing in the development of commercial activities of companies in terms of growth of consumption of content was revealed.

Keywords: mobile marketing, advertising, promotion, target market.
\end{abstract}

В последнее время такие термины, как «мобильный маркетинг» или «мобильная реклама» довольно прочно вошли в лексикон маркетологов и получили широкое распространение. Однако на сегодняшний день далеко не каждый менеджер определит четкие границы между данными понятиями, раскроет функциональные особенности мобильного маркетинга. Вместе с тем, мобильный маркетинг является мощным инструментом развития бизнеса в современных экономических условиях. В данном контексте актуализируется проблема эффективной организации мобильного маркетинга, выявлению тенденций и перспектив его развития.

Мобильный маркетинг зарекомендовал себя как эффективный способ коммуникации потребителя и рекламодателя, способствующей росту объемов продаж, а соответственно и чистой прибыли. На данный момент существует значительное количество продвижения товара (услуги): проведение акций; плакаты, баннеры, объявления в печатных изданиях; использование промороликов и др. При этом мобильный маркетинг также является эффективным способом рекламы товара, предполагающим использование средств связи как инструментов продвижения. Объектом мобильного маркетинга выступает любого рода информация, представленная в виде картинки, анимации, видеоролика или программы, которая может быть отправлена на мобильный телефон. Важную роль играет тот факт, что мобильный контент может быть загружен единожды и храниться на устройстве долгое время, будучи использованным в нужный момент.

Вместе с тем, далеко не многие российские компании эффективно используют данный инструмент стимулирования продаж. Рассматривая SMS-рассылки, можно заметить, 
что сотовые операторы не делают упор на целевую аудиторию, а вместо этого рассылают рекламные сообщения всем категориям пользователей. При планировании рекламной кампании, основным инструментом которой является SMS-маркетинг, следует четко представлять характеристики целевой аудитории потребителей и учитывать их при разработке комплекса маркетинга, программ и планов развития рыночной деятельности. Следует особо отметить, что аудитория пользователей мобильных сетей - это колоссальный ресурс, который по охвату можно сравнить с телевизионной аудиторией.

Следует отметить, что мобильный маркетинг охватывает практически все сферы современной общественной жизни и является мощным инструментом для развития бизнеса. Согласно данным исследования, проведённого маркетинговой агентством J'son \& Partners Consulting, в 2011г. рост рынка мобильного маркетинга составил всего 43\%, однако, исследуемый рынок уже в 2012 году вырос на $78 \%$ [1].

Активное использование данного вида рекламы напрямую связано с расширением рынка мобильных устройств, функционал которых практически не отличается от возможностей стационарных компьютеров и ноутбуков. В свою очередь, рост продаж вышеперечисленных устройств связан с появлением на рынке обилия мобильных операционных систем, практически не ограничивающих пользователя в технических возможностях, что чрезвычайно важно в наше время.

Целевой аудиторией современных «гаджетов» являются люди, активно потребляющие контент: скачивающие музыку, просматривающие онлайн видео, просматривающие информацию. Происходит это посредства канала Wi-Fi или GPRS. Начиная c 2013г. доля потребляемого контента на мобильных устройствах превысила долю контента на персональных компьютерах. Благодаря всем вышеперечисленным фактора появляется новый рынок (рынок мобильного маркетинга), предоставляющий маркетологам дополнительные возможности применения инструментов Интернет-маркетинга.

В настоящее время мобильный маркетинг рассматривается многими компаниями в первую очередь как новая сфера коммерческой деятельности. Впервые мобильная коммерция проявилась в 1997г., когда в Хельсинки появились два автомата по продаже Coca-Cola, принимавшие платежи через SMS [2]. В действительности мобильный маркетинг стал прибыльным лишь несколько лет назад, когда многие рынки услуг (в т.ч. рынок мобильных приложений, рынок Интернет-покупок) получили широкое распространение в развитых странах. В настоящее время можно выделить несколько основных направлений развития рынка мобильного маркетинга:

- WAP-реклама, использующая создание различных Интернет-порталов;

- SMS-маркетинг - реклама, распространяемая по средствам рассылки SMS-сообщений рекламного характера;

- программное обеспечение - разработка фирменного программного обеспечения для мобильных устройств, покупка рекламы в иных мобильных приложениях;

- Wi-Fi-маркетинг - показ рекламы исключительно

пользователям, подключившимся к определённой Wi-Fi-сети;

- IVR - система рекламы, базирующаяся на заранее записанных голосовых сообщениях, несущих в себе рекламный характер;

- реклама во время голосового звонка.

На сегодняшний день, несмотря на уровень развития информационных технологий, реклама в SMS рассылках остаётся одним из самых распространённых видов среди мобильной рекламы. Сообщения часто используются для 
оповещения уже действующих клиентов о новых акциях или скидках.

Экономическую эффективность рынка мобильного маркетинга также подтверждают данные аналитической компании GazpromMedia Digital, отражающие объём рынка мобильного маркетинга в России (рис. 1).

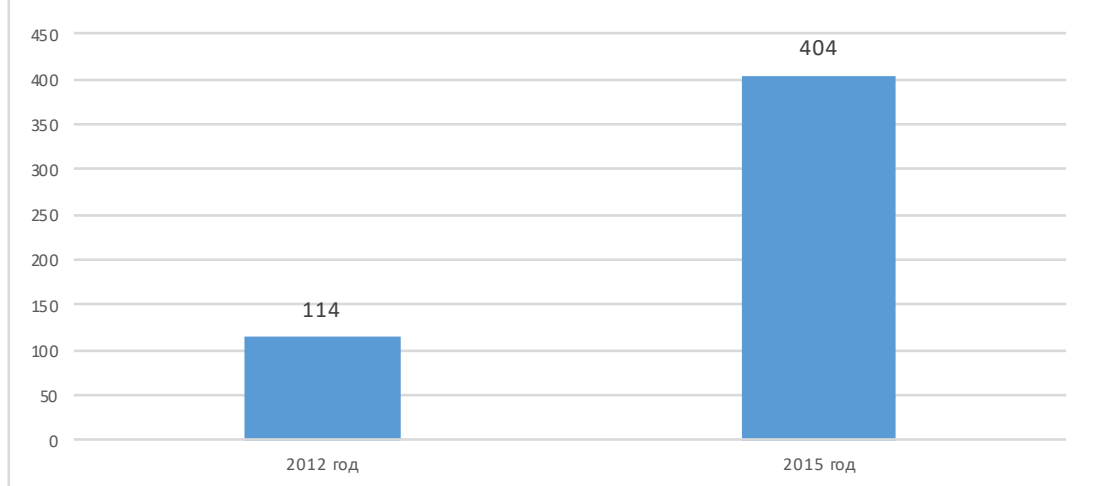

Рисунок 1 - Динамика развития рынка мобильного маркетинга в России, млрд. долл., 2012-2015 z2.

Данные рис.1 подтверждают положительную динамику рынка мобильного маркетинга, обусловленную соответствующим уровнем эффективности.

Таким образом, анализ такого функционального направления как мобильный маркетинг подтверждает его потенциал в развитии коммерческой деятельности фирмы, росте объемов продаж. Потребительский спрос на мобильные устройства с каждым годов лишь растет, вместе с ним растет и потребление различных видов контента. На сегодняшний день каждая динамично развивающаяся компания имеет в своём арсенале не только персональный корпоративный сайт, но и его мобильную версию для удобства пользования с мобильных устройств.

\section{ЛИТЕРАТУРА}

1.Крупин, А. В 2011 году рынок мобильной рекламы вырастет на 43\%. [Электронный peсурс]. - Режим доступа: http://www.3dnews.ru/news/612834.

2.Палладин, А. Мобильная коммерция: надежды сбываются. [Электронный ресурс]. Режим доступа: http://www.cisco.com/web/RU/news/releases/txt/2011/051911b.html. 


\title{
МЕРЫ ГОСУДАРСТВЕННОЙ ПОДДЕРЖКИ МАЛОГО И СРЕДНЕГО ПРЕДПРИНИМАТЕЛЬСТВА В СОВРЕМЕННОЙ ЭКОНОМИКЕ
}

Шелехова Л.В

д.п.н.,профессор, Адыгейский государственный университет, г.Майкоп

Татлок A.P

студент, Адыгейский государственный университет, г.Майкоп

Аннотация: В статье рассмотрены актуальные проблемы развития малого и среднего бизнеса в условиях современной экономики. Раскрывается современное состояние и стратегические направления государственной поддержки. Проанализированы факторы, препятствуюшие развитию малого и среднего бизнеса в РФ.

Ключевые слова: государственная поддержка, меры, факторы, малый и средний бизнес.

\section{MEASURES OF STATE SUPPORT OF SMALL AND MEDIUM ENTREPRENEURSHIP IN THE MODERN ECONOMY}

Schelekhova L.V

Doctor of Pedagogy, Professor, Adyghe State University, g. Maykop

Tatlok A.R student, Adygei state university, Maikop

\begin{abstract}
The article deals with actual problems of development of small and medium businesses in today's economy. Expands the current state and the strategic directions of the state support. The factors impeding the development of small and medium-sized businesses in Russia.

Keywords: State support measures factors, small and medium businesses.
\end{abstract}

В РФ государство является главной движущей силой, которая влияет на экономическое развитие страны через органы федеральной и региональной власти. В условиях рыночной экономики государство не вмешивается напрямую в конкурент ную борьбу, однако правительственные структуры ежегодно должны совершенствовать условия ведения бизнеса, используя различные инструменты и меры государственной поддержки. Несмотря на это на территории России на данный момент предпринимательство не является опорой и поддержкой экономики страны. На долю малого и среднего бизнеса приходится около $20 \%$ ВВП, при этом следует отметить, что в зарубежных странах только на малый бизнес приходится $50 \%$ ВВП.

По статистике лишь $3,4 \%$ МСБ по истечению трех лет удается не закрыться, а продолжить свою предпринимательскую деятельность. К сожалению, показатели говорят нам о том, что прирост открытия уступает приросту прекращения и ликвидации малого и среднего бизнеса: на 4\% ежегодно увеличиваются ИП, на $11 \%$ увеличиваются случаи закрытия. По данным Федеральной Налоговой Службы на апрель 2015 г. было в ЕГРИП зарегистрировано 3,5 млн индивидуальных предпринимателей, при этом 7, 7 млн человек за все время прекратил и предпринимательскую деятельность [5]. Государство осознано идет на снижение поступлений в бюджет налогов и взносов предоставляя льготы для МСБ. Безусловно данная стратегия имеет ряд целей: создание рабочих мест, снижение уровня безработицы, развитие новых видов деятельности, организация небольших инновационных производств. Именно поэтому малый и средний бизнес пользуются большой государственной поддержкой. 
В июле 2015 года была создана новая государственная структура в области регулирования и поддержки МСБ - АО «Федеральная корпорация по развитию малого и среднего предпринимательства» . Данная Корпорация МСП проводит свою деятельность по следующим направлениям: создание маркетинговых региональных карт; решение вопросов организационного взаимодействия между субъектами МСП и инфраструктурами-моно полиями,

государственными

компаниями

И

акционерными обществами с участием государства с точки зрения государственных закупок; формирование и активизация работы сети региональных лизинговых центров; координация деятельности

блока имущественной поддержки в регионах; разработка и внедрение программ оказания информационно-ко нс ультационных услуг предпринимателям через региональные многофункцио нальные центры России [1]. На данный момент некорректно оценивать влияние данной программы на предпринимательский климат РФ, так как Корпорация полноценно начнет процесс реализации в 2017 году.

Эффективность развития малого и среднего бизнеса зависит от капитала собственника, доступности получения финансовых ресурсов. В РФ основным видом финансовых ресурсов является кредит. Не смотря на положительную тенденцию снижения ключевой ставки: 16.12.2014 г. - 17\% годовых, 02.02 .2015 г. - 15\%, 16.03.2015 г. - 14\%, 30.04 .2015 г. $-12,5 \%, 16.06 .2015$ г. $-11,5 \%$, 03.08 .2015 г. - 11\%, с 19.09.2016 г. и по настоящее время - 10\% годовых, средняя ставка по банковским кредитам для субъектов малого и среднего бизнеса составляет 15\% $17 \%$ [2]. Не смотря на положительную тенденцию кредитования МСБ, наша банковская система далеко от систем развитых стран, в которых кредиты бизнесу предоставляются под 3-4\%. Данная процентная ставка дает возможность при успешном развитии дела, перекрывать издержки производства, при этом не оставляя прибыли владельцу. На сегодняшний день путь к разрешению данного препятствующего фактора неразрывно связан с частными инвестициями в бизнес, которые могут стать более привлекательным видом финансовых ресурсов для предпринимателей. Президент РФ В.Путин утверждает, что ситуация далеко не радужная, так как мы проигрываем нашим конкурентам на мировом уровне по инвестиционной привлекательности, в первую очередь, по причине значительного оттока капитала из России [3].

В 2014 году экономика России столкнулась с рядом серьезных экономических проблем: неблагоприятная конъюнктура на мировых рынках, санкции. В 2015 году предприниматели ощутили снижающийся спрос на товары и услуги, при значительно м росте цен на сырье, вызванном изменением курса рубля.

Проблема высокого налогообложения актуальна для предпринимателей во все времена. Следует отметить, что малому и среднему бизнесу предоставлены достаточно оптимальные условия: каждое предприятие имеет право самостоятельно выбирать режим налогообложения. Одним из таких режимов является упрощенная налоговая система, направленная на снижение налоговой нагрузки на субъекты малого бизнеса, облегчение и упрощение ведения налогового и бухгалтерского учета. С 1 января 2015 г. вступил в силу закон о налоговых каникулах, Ф3 №477 от 29.12.2014 « О внесении изменений в статью 346 и главу 26 части второй Налогового кодекса Российской Федерации». Согласно данному изменению ИП производственной, социальной, научной 
сферы могут быть освобождены от налогов на два налоговых периода, при этом следует отметить, что это относится только к предприятиям, зарегистрированным с 2015 года по 2020 год. Для того чтобы предприятие получило налоговые каникулы, необходимо также выбрать налоговый режим ПСН или УСН. Ряд льгот для малого и среднего бизнеса было прописано в распоряжении Правительства РФ от 27 января 2015 года №98-p «O плане первоочередных мероприятий по обеспечению устойчивого развития экономики и социально й стабильности в 2015 году». Следует отметить, что в результате число зарегистрированных ИП по с равнению с декабрем 2014 года к январю 2015 года увеличилось на 14\%. Налоговая политика РФ направлена на стимулирование предпринимательства. В России для малого бизнеса разработаны следующие системы с максимально низкими ставками по налогам: УСН, ЕНВД, ПСН, ЕСХН. В 2016 году региональным властям предоставлена возможность устанавливать на своей территории для плательщиков ЕНВД и УСН более низкие налоговые ставки, чем предусмотрено данными режимами: по ЕНВД снижение с 15\% до 7,5\%, по УСН - с 6\% до $1 \%$. В данном случае государству преследует цель создание дополнительных рабочих мест и получение страховых взносов за работников.

Не менее важным препятствующ им фактором являются административные барьеры. Безусловно государство не могло не обратить внимание на данную проблему, которая заключается в: сложном законодательстве, состоящем из ряда административных трудностей, сложном порядке отчетности, оформление кадров и денежных расчетов, частых проверках надзорных органов, нежелание банков выдавать необеспеченные кредиты. В 2016 году правительством РФ были внесены следующие изменения:

1)плательщики ЕНВД и ПСН вправе проводить наличные расчеты без применения кассового аппарата до июля 2018 года;

2)малый бизнес может вести упрощенный вид бухгалтерского отчета;

3)малые организации и ИП имеют право вести кассовые операции в упрощенном порядке и не устанавливать лимит кассы;

4)работодатели малого бизнеса вправе оформлять срочные трудовые договоры до 5 лет при условии: численность персонала не превышает 35 человек, работник должен дать свое согласие на заключение срочного договора;

5)надзорные каникулы для малого бизнеса на период с 2016 года по 2018 год;

6)региональные и местные власти в субъектах РФ могут заключаться с представителям и малого бизнеса договоры аренды зданий и помещений на льготных условиях в течение 5 лет, а также предоставлять арендаторам преимущественное право выкупа такого имущества до 1.07.18 г.;

7)при получении банковского кредита предприятие может обратиться в гарантийные организации для получения государственной гарантии, что в значительной степени повысит шанс получения кредита;

8)для участия представителей малого бизнеса в государственных закупках предусмотрена специальная льгота - госзаказчики обязаны производить не менее $15 \%$ совокупного годового объема закупок у этой категории.

Малому и среднему бизнесу также предоставляется финансовая поддержка, которая в большей степени проявляется в виде субсидий:

1)на возмещение части затрат по договорам лизинга;

2)на возмещение части затрат на уплату процентов по кредитам и займам; 
3)на возмещение части затрат, связанных с участием в конгрессно-выставочных мероприятия х;

4)для начинающих предпринимателей до 500 тыс.руб.

В рамках Федеральной программы, продолжающейся до 2020 года, безвозмездные субсидии и гранты предоставляются малому бизнесу.

Несмотря на то обстоятельство, что в течение 2015 года происходила модификация условий для ведения предпринимательс ко й деятельности малых и средних рыночных структур, существует ряд нерешенных вопросов: выход на рынки субъектов малого и среднего бизнеса; размещение продукции в торговых сетях; недобросовестное посредничество при сбыте продукции; «нежелательное» участие малого и среднего бизнеса в государственных закупках и выполнении государственных заказов. Для разрешения поставленных проблем необходимо точно определить причины, препятствующие развитию полноценного функционирования бизнеса. Безусловно, на данный момент негативное влияние на развитие МСБ оказывают экономические барьеры, административная и налоговая система. В Законодательстве РФ нет четко прописанной системы для ведения малого и среднего бизнеса, в силу постоянных изменений, которые влекут за собой ряд негативных последствий

для

предпринимателе й: отсутствие информированности, штрафы за ошибки в документации [6].

Следует отметить, что главные причины снижения темпов развития экономики - это наши внутренние проблемы: дефицит инвестиционных ресурсов, современных технологий, профессиональных кадров, недостаточное развитие конкуренции, неблагоприятный деловой климат. В большинстве случаев это происходит по причине отказа от полного воспроизводственного процесса, в результате которого прибыль выходит из бизнеса, не попадая в дальнейшее его развитие. Для бизнеса государство предоставило необходимую и достаточную свободу. Предприниматели не готовы вкладывать в бизнес, не осознавая, что не получая капитальных вложений, ни развития, ни поддержания п предпринимательс ко й деятельности на определенном уровне не возможно. Именно поэтому не стоит в данной проблеме винить только не эффективные инструменты государственного вмешательства, следует признать неумение грамотного ведения бизнеса.

Таким образом, темпы развития малого предпринимательства в первую очередь определяется тем, насколько активно и эффективно органы государственной власти осуществляют полдеру предпринимательству. Даже несмотря на проблемы в создании и возникающие на пути трудности малых предприятий, государство всячески старается поддержать и простимулировать это направление бизнеса. Главное чтобы государственная поддержка создавала те условия, при которых малый бизнес начнет оказывать положительное влияние на социально-экономическ ие показатели страны.

\section{ЛИТЕРАТУРА}

3.Налоговые и бухгалтерские изменения с 2015 года [Электронный ресурс]. - Режим доступа: http://www.glavbukh.ru/art/21421-nalogovye-i-buhgalterskie-izmeneniya-s2015 -goda. 
4. Браверман, А. «ТПП-Информ: Торгово-промышленные ведомости» [Электронный peсурс]. - Режим доступа: http://www.tpp-inform.ru/analytic_journal/6295.html.

5. Налоговые и бухгалтерские изменения с 2015 года / Электронный журнал «Главбух» [Электронный ресурс]. - Режим доступа: http://www.glavbukh.ru/art/21421 nalogovye-i-buhgalterskie-izmeneniya-s-2015-goda.

6. Российский Банк поддержки малого и среднего предпринимательства» [Электронный ресурс]. https://www.ms pbank.ru/userfiles/files/researches/14_10\%20MSP_broshura_block2-10 .pdf/.

7. НАФИ. Аналитический центр [Электронный ресурс]. - Режим доступа: http://nacfin.ru/v-ozhidanii-vnyatnyx-pravil/.

8. Шелехова, Л.В. Малый бизнес как фактор стабильности экономики региона (на материалах Республики Адыгея) / Л.В. Шелехова, К.А. Минченко // Сборник научных трудов по материалам II Всероссийской научно-практической конференции «Проблемы и перспективы социально-экономического развития регионов Юга России».Майкоп: Изд-во АГУ, 2015. - С. 158-164.

9. Мокрушин, А.А. Стратегические приоритеты развития региональных экономических систем // Вестник Адыгейского государственного университета. Серия 5: Экономика, 2010. № 3 - С. 78-80.

10. Тамов, А.А. Методические аспекты оценки стратегического потенциала региональных среднесрочных программ // Вестник Адыгейского государственного университета. Серия 5: Экономика, 2010. №3. - С. 66-72. 
ПРОБЛЕМЫ ГОСУДАРСТВЕННОГО РЕГУЛИРОВАНИЯ РАЗВИТИЯ АГРОПРОМЫШЛЕННОГО КОМПЛЕКСА

Тлехатук Ф.P. Адыгейский государственный университет, г. Майкоп Научный руководитель: Мокрушин А.A. д.э.н, профессор, Адыгейский государственный университет, г. Майкоп

Аннотация. В данной статье рассмотрень проблемы государственного регулирования развития отечественного агропромышленного комплекса. Раскрыта необходимость эффективного государственного регулирования агропромышленного производства в современных рыночных условиях. Представлены механизмы воздействия государства на агропромышленный комплекс.

Ключевые слова: государственное регулирование, агропромышленный комплекс, сельское хозяйство, рыночные условия, аграрная политика, механизмы.

\title{
PROBLEMS OF STATE REGULATION OF DEVELOPMENT OF AGROINDUSTRIAL
} COMPLEX

Tlehatuk F.R. Adyghe State University, Maikop Supervisor: Mokrushin A.A. PhD, Professor, Adyghe State University, Maikop

\begin{abstract}
This article describes the main problems of state regulation of development of the domestic agro-industrial complex. The necessity of effective state regulation of agricultural production in current market conditions are revealed. Mechanisms of state influence on agriculture are presented.
\end{abstract}

Keywords: state regulation, agribusiness, agriculture, market conditions, agricultural policy, mechanisms.

Агропромышленный комплекс имеет особое значение в экономике страны, и является самым крупным из основных (базовых) комплексов в экономике страны. В АПК России в сфере материального производства в настоящее время занято около $35 \%$ всех работающих. Здесь создается почти 15\% ВВП и сосредоточено более четверти все производственных фондов. В воспроизводственные связи с аграрным сектором включено около $30 \%$ отраслей народнохозяйственного комплекса. Из сельскохозяйственного сырья производится примерно 70\% всего набора производимых в стране предметов потребления. Примерно половину составляют продовольственные товары в розничном товарообороте.

Без государственного регулирования рыночная экономика не может действовать и существовать. В агропромышленном комплексе государственное регулирование предполагает его осуществление преимущественно экономическими методами и защищает отечественный продовольственный рынок от импорта, а также от высокомонополизированных отраслей аграрного сектора, производящих для сельского хозяйства средства производства и закупающих его продукцию; совершенствование и сохранение функции государства в условиях переходного периода в качестве заказчика и инвестора; поддержание государственного сектора агропромышленного комплекса; содействие развитию рыночной инфраструктуры; подготовка кадров для сельского хозяйства и 
развитие аграрной науки; развитие социальной сферы села. В условиях рынка такое влияние государства на деятельность хозяйствующих субъектов относится к главным принципам современной рыночной эКОНомики.

Государственное регулирование должно осуществляться для предупреждения нарушений, при нарушении равновесия и для поддержания стабильности. Процесс вмешательства государства в аграрную сферу экономики в современных условиях может осуществляться с различной степенью. На развитие аграрного сектора выявлено три основных типа регулирующего воздействия:

- централизованный государственный монополизм;

- экономический либерализм;

- смешанный тип, т.е. сочетание государственных и рыночных регуляторов.

Активное воздействие на развитие агропромышленного комплекса экономическими методами государство может осуществлять через бюджетное финансирование, налоговое и кредитное регулирование, регулирование условий и уровня оплаты труда, социальное развитие, через государственные

госзаказы, эффективную программы, политику и т. д.

Развитие экономики, разработка системы мер государственного регулирования и поддержка агропромышленного комплекса, является важнейшим условием его дальнейшего развития. $\mathrm{K}$ ним относятся выработка стабильной и четкой государственной политики регулирования отношений в аграрной сфере, создание стабильных отношений, наличие законодательства, поддерживающего перестройку отношений в сельском хозяйстве и функционирование в системе рыночных отношений.
Несмотря на провозглашенный курс бездотационного развития АПК государство вынуждено принимать десятки законодательных актов и постоянно решать вопросы финансовой поддержки АПК в целом И ЛЬГОТНОГО

кредитования сельскохозяйственных производителей, особенно кредитной поддержки фермерства и сельскохозяйственных кооперативов, иных сельскохозяйственных производителей, введения льготного страхования посевов за счет федерального бюджета, вопросы отсрочки, переоформления и списания задолженности по ссудам сельскохозяйственных предприят ий, процентам и штрафам по ним, о компенсации сельским товаропроизводителям и хлебоприемным предприят ия м железнодорожных тарифов ПО транспортировке продукции, об установлении специальных тарифов на электрическую энергию сельскохозяйственным товаропроизводителям.

Обосновано положение о возрастании влияния региональных особенностей на развитие агропромышленного сектора экономики проблемных регионов Юга России в современных условиях. Под региональным и особенностями развития АПК региона в настоящем исследовании понимаются специфические характеристики этого сектора, базирующиеся на природно-климатических, географических, ресурсных, структурных и прочих особенностях самого региона.

Возрастание роли региональных особенностей в развитии АПК проблемных регионов Юга России следует рассматривать в контексте исследования более масштабного явления - растущего влияния этого фактора на весь процесс социально-эко номического развития этих регионов, обусловленного, с одной стороны, воздействием на них процессов глобализации, с другой стороны, - 
проводимой

федеральным

политикой,

ориентирующей

регионы на всемерное

центро м

указанные

оздоровление

экономики как магистральный путь решения их социальных проблем.

Одна из серьезных проблем

сельскохозяйственного производства - резкое снижение объема инвестиций. Низкая рентабельность отраслей АПК в целом, закредитованность и постоянный недостаток собственных оборотных средств, а также отсутствие ликвидного залогового имущества делают его отрасли неперспективными для капитальных вложений, а следовательно обрекают их на стагнацию. Снижение инвестиционной активности ведет к физическому и моральному старению основных фондов, износ которых по отдельным отраслям АПК составляет от 50 до
70\%. Одним из вариантов улучшения финансирования сельского хозяйства может стать возрождение сельской кредитной кооперации. Кооперативы могут объединять собственные средства, свободные средства сельского населения, а также средства жителей малых городов. Но здесь на первых порах со стороны государства должна быть оказана конкретная помощь в виде льготных банковских кредитов.

Очевидно, что кризис в сельском хозяйстве вызван не только объективными природным и условиями, но и просчетами в реализации аграрной политики. Таким образом, государство должно участвовать в рыночных процессах на правах субъекта рыночных отношений, обеспечивая устойчивое развитие агропромышленного производства.

\section{ЛИТЕРАТУРА}

1. Афанасьев, В.Н Государственная поддержка и государственное регулирование агропромышленного производства. / В.Н. Афанасьев, А.П. Мартынов, А.С. Пешков // - Оренбург, 2003 - 94 с.

2. Карташов, Л.П. Повышение надежности системы «человек- машина - животное». Екатеринбург, $2000-124$ с.

3. Огородников, П.И. Научно-технический прогресс- основа эффективной реализации инновационных проектов в АПК // под ред. А. Татаркина. Екатеринбург: Институт экономики УрО РАН, $2009-145$ с.

4. Хорохорин, А.О. О проблемах функционирования АПК и путях их решения. - М., $2006-94$ c.

5. Мокрушин, А.А. Корпоративное управление интеграционными трансакциями в АПК региона: функциональные особенности, критерии эффективности / А.А. Мокрушин, С.В. Кесян // Новые технологии, 2013. №4. - С. 61-67.

6. Мокрушин, А.А. Корпоративный потенциал структурной модернизации региональных агропродовольственных систем современной России / А.А. Мокрушин, А.И. Суслов // Вестник Адыгейского государственного университета. Серия 5: Экономика, 2012. № 1. - С. 110-119.

7. Тамов, А.А. Роль АПК в реализации региональных интересов / А.А. Тамов, М.К. Тамова // Вестник Адыгейского государственного университета. Серия 5: Экономика, 2014. № 2(141). - C. 158-161.

8. Апишев, А.А. Стартовые условия вхождения регионального АПК в рынок / А.А. Апишев, А.А. Тамов, М.К. Тамова // Вестник Адыгейского государственного университета. Серия 5: Экономика, 2015. № 3(165). - С. 215-219. 


\title{
ТЕРРИТОРИАЛЬНО-ОТР АСЛЕВЫЕ ОСОБЕННОСТИ РАЗВИТИЯ АПК РЕСПУБЛИКИ АДЫГЕЯ
}

Тлехатук Ф.P. Адыгейский государственный университет, г. Майкоп Научный руководитель: Мокрушин $\boldsymbol{A}$.А. д.э.н., профессор, Адыгейский государственный университет, г. Майкоп

\begin{abstract}
Аннотация. В статьераскрыта специфика хозяйствованияв агропромышленном секторе проблемных регионов Юга России. Раскрыты территориально-отраслевые особенности развития агропродовольственного сектора Республики Адыгея на современном этапе развития.
\end{abstract}

Ключевые слова: агропромышленный комплекс, сельское хозяйство, территориально-отраслевые особенности, Республика Адыгея, Юг России.

\section{TERRITORIAL-BRANCH FEATURES OF DEVELOPMENT OF AGRICULTURE OF THE REPUBLIC OF ADYGEA}

Tlehatuk F.R.

Adyghe State University, Maikop Supervisor: Mokrushin A.A. PhD, Professor, Adyghe State University, Maikop

\begin{abstract}
The article describes the specificity of management in the agricultural sector problematic regions of Southern Russia. The territorial and sectoral characteristics of the development of the agricultural sector of the Republic of Adygea at the present stage of development were revealed.
\end{abstract}

Keywords: agribusiness, agriculture, territorial and sectoral characteristics, The Republic of Adygea, Southern Russia.

Проблемные регионы Юга России, включая Республику Адыгея, после двух десятилетий рыночных трансформаций значительно отстают как от регионов-лидеров макрорегиона, так и от среднероссийского уровня развития по таким показателям как ВРП на душу населения, денежные доходы, инвестиции в основной капитал. При этом территориально-отраслевые особенности проблемных регионов во многом предопределяют вектор их стратегического развития.

Следует отметить возрастание роли региональных особенностей в развитии АПК проблемных субъектов РФ. Территориальные особенности развития представляют собой АПК региона характеристики данной сферы народного хозяйства, базирующиеся на природно климатических, географических, ресурсных, структурных и прочих особенностях самого региона.

Региональная специфика хозяйствования в агропромышленном секторе экономики проблемных регионов Юга России предопределена следующими факторами:

- текущим состоянием и имеющимся агроклиматическим потенциалом, определяющим условия для ведения сельскохозяйственного производства и развития перерабатывающих отраслей; - инерцио нностью, связанной с размещением в регионе материальных факторов (земельных ресурсов, зданий, сооружений, многолетних насаждений и др.); - состоянием и потенциалом других 
секторов экономики региона, с которыми агропромышленный сектор активно взаимодействует;
- характером

стратегических

решаемых

текущих и задач экономического развития региона;

- динамичностью и растущей

неопределенностью

природно -

климатических, экономических и других условий функционирования АПК.

Республика Адыгея, занимающая анклав ное положение по отношению к Краснодарскому краю, является одним из малых проблемных регионов Юга России, сравнительно благополучным фоном остальных национально-территориаль ных автономий макрорегиона, но значительно уступающим по уровню социально-эко номичес кого развития регионам-лидерам, в частности, Краснодарскому краю, Ростовской области и т.д.

Тенденции развития АПК и сельского хозяйства Республике Адыгея в значитель но й степени обусловлены степенью инфраструктурного обеспечения, инновацио нно-инвестицио нной привлекательностью аграрного сектора и соответствующим уровнем эффективности производства. Перспективы развития региональной экономики аграрного сектора неразрывно связаны с формированием системы инфраструктурного обеспечения агропродовольственных

рынко в, определяются интенсив нос тью инновацио нной инвестицио нно й деятельности.

Коллективные хозяйства в отечественном АПК реорганизованы в различные формы собственности. Так, в Адыгее завершена приватизация обслуживающих и перерабатывающих организаций. В целом, в региональном АПК складывается сочетание частного и государственного, крупного, среднего и малого сельскохозяйственного производства.

Предприятиям аграрного сектора

Республики Адыгея отводится существенная роль в решении проблемы обеспечения населения продуктами питания. В 2013 г. удельный вес продукции АПК составляет порядка $\quad 53 \% \quad$ от общего объема промышленного производства региона. В сельском хозяйстве Республики Адыгея преобладают посевы зерновых и масличных культур, развитие получили овощеводство и бахчеводство, выращивание винограда и плодов. Основу животноводства составляют разведение крупного рогатого скота, птицеводство и пчеловодство.

Предприятия пищевой промышленности Республики Адыгея продолжают оставаться в сложном экономическом положении. Недостаток оборотных средств не позволяет организациям решать вопросы обеспечения сырьем и материалами, работать устойчиво и прибыльно.

Маслосыродельная и молочная промышленность в регионе объединяет 8 предприятий. Производство молочной продукции в Республике Адыгея осуществляют ОАО Молзавод «Гиагинский» $(57,5 \%)$, ООО «Тамбовский» $(15,3 \%)$, ОАО Молзавод «Шовгеновский» $(11,6 \%)$, ООО «Гюмри» $(1,4 \%), \quad$ ООО «Красноульский молзавод» $(1,3 \%), \quad 3 \mathrm{AO}$ Молкомбинат «Адыгейский» (0,3\%), а также индивидуальные предприниматели. Важно отметить, что в большинстве случаев основной выпускаемой продукцией является сыр. Производство молока, кефира и других молочных продуктов развито не достаточно.

\section{Лидирующее положение занимает ОАО} «Молзавод «Гиагинский», на долю которого приходится более $65 \%$ перерабатываемого сырья. Завод представляет собой большое промышленное предприятие с годовым 
оборотом продукции более 800 млн. руб. Ассортимент выпускаемой продукции состоит из 6 наименований масла и спредов, 12 видов сыров и сухой молочной сыворотки. Ежегодно предприятие производит около 3200 т мягких и полутвердых сыров, 2500 т масла и спредов, более 2000 т сухой молочной сыворотки. На завод сдают свою продукцию основные производители молока региона. ОАО «Молзавод «Гиагинский» является одним из немногих финансово-устойчивых и прибыльных организаций пищевой промышленности региона. С целью технологической модернизации на освоение инвестиционных проектов было направле но более 60 млн. руб., что позволило производить качественную конкурентоспособную продукцию. Благодаря внедрению упаковочной установки «Дарфреш» срок хранения сыров увеличен до 1,5 месяцев. Сыры, производимые на данном предприятии, пользуются повышенным спросом на потребительском рынке России. Республика Адыгея запатентовала право собственности на торговый бренд «Сыр Адыгейский», что дает право на его производство только предприятиям региона. Запущены новые линии по фасовке кефира и молока в полистироновые стаканчики. Последняя новинка предприятия кисломолочный напиток «Айран», изготовляемый по уникальному рецепту.

В Республике Адыгея мясная
перерабатывающая отрасль представлена несколькими крупными и двумя действующими малыми предприятиями по производству колбасных изделий и мясных полуфабрикатов. В регионе действует группа агропредприятий «Ресурс», которая занимается производством комбикормов, получением инкубационных яиц, выращиванием и переработкой цыплятбройлеров, производством и реализацией замороженной и охлажденной продукции из мяса птицы.

Пищевая промышленность по объемам производства продукции является одной из ведущих отраслей промышленности Республики Адыгея. В регионе по состоянию на 2015 г. функционировало более 230 предприятий пищевой промышленности. Качество продукции, выпускаемой организациями пищевой промышленности, традиционно удостаивается высших наград на различных конкурсах, ярмарках, выставках.

\section{Организационно-эко номические}

преобразования

агропромышлен- но го комплекса повлекли ряд существенных негативных последствий: снижение объемов производства продукции сельского хозяйства и перерабатывающей промышленности ; отсутствие необходимой господдержки инфраструктурных преобразований привело к многократному снижению объемов закупок новой техники и оборудования и, как следствие, росту износа большей части основных средств сельскохозяйственных организаций.

В настоящее время потребительский рынок Республики Адыгея заполнен в основном сельскохозяйственной продукцией и продуктами питания, произведенным и зарубежными компаниями, а также товаропроизводителями других российских регионов. Предприятия пищевой промышленности региона с трудом выдерживают конкурентную борьбу с продукцией известных торговых марок. Региональная розничная торговля ставит в одну ценовую нишу продукцию местных производителей и ввозимую пищевую продукцию, что способствует ее вытеснению с собственного рынка.

Не менее важной проблемой остается отсутствие собственных оборотных средств, 
что привело предприятия к зависимости от заемного капитала. Доля заемного капитала в формировании оборотных активов составляет 80-84\%. Недостаток собственных оборотных средств и низкая рентабельность производимой продукции лишают предприятия возможности обновления и реконструкции производственных мощностей. В частности, в Республике Адыгея на конкурентоспособность молочной продукции влияет количество и качество используемого инновацио нных сырья, технологий, примене ние технологическое оснащение технико отрасли, возможность привлечения инвестиций, уровень внедрения систем менеджмента качества, квалификации и профессионализм кадров. При функционировании продуктовых рынков Республики Адыгея наблюдается сокращение объемов производства и запасов сельскохозяйственного сырья И продовольствия.

Таким образом, производство пищевых продуктов нестабильно, объемы значительно ниже норм потребления. Проведенный анализ свидетельствует о постепенном росте объемов пищевой продукции, производимой в Республике Адыгея, кроме масла животного, сахара и макаронных изделий. Уровень потребления по большинству товарных позиций превышает производство, недостаток компенсируется, преимущественно за счет импорта.

\section{ЛИТЕРАТУРА}

1. Гайдук, В.И. Формирование рыночных отношений в АПК (теория и методология)/ В.И. Гайдук, С.С. Вороков // - Краснодар: КГАУ, 2002. - 146 с.

2. Багмут, С.В. Формирование оптового продовольственного рынка региона / В.И. Гайдук, С.В. Багмут // Вестник Московского университета. Серия 6: Экономика, 2012. №5. - C. 77-85.

3. Багмут, С.В. Формирование инфраструктуры агропродовольственного рынка Республики Адыгея / В.И. Гайдук, С.В. Багмут // Международный сельскохозяйственный журнал, 2012. №6. - С. 3-5.

4. Багмут, С.В. Экономическая эффективность инвестиций в строительство складов плодоовощной продукции в республике Адыгея / В.И. Гайдук, С.В. Багмут //Политематический сетевой электронный научный журнал Кубанского государственного аграрного университета (Научный журнал КубГАУ). - Краснодар: КубГАУ, 2014. №4(098). - С. 65-80. [Электронный ресурс]. - Режим доступа: http://ej.kubagro.ru/2014/04/pdf/04.pdf .

5. Официальный сайт Министерства сельского хозяйства Республики Адыгея [Электронный ресурс]. - Режим доступа: http://www.mcx-ra.ru.

6. Официальный сайт Министерства экономического развития и торговли Республики Адыгея [Электронный ресурс]. - Режим доступа: http://www.minecora.ru.

7. Официальный сайт Территориального органа Федеральной службы государственной статистики по Республике Адыгея. [Электронный ресурс]. - Режим доступа: http://www. adg.gks.ru.

8. Официальный сайт исполнительных органов государственной власти Ре спублики Адыгея. [Электронный ресурс]. - Режим доступа: http://www.adygheya.ru.

9. Мокрушин, А.А. Корпоративный потенциал структурной модернизации региональных агропродовольственных систем современной России / А.А. Мокрушин, 
А.И. Суслов // Вестник Адыгейского государственного университета. Серия 5: Экономика, 2012. №1. - С. 112.

10. Мокрушин, А.А. Корпоративное управление интеграционными трансакциями в АПК региона: функциональные особенности, критерии эффективности / А.А. Мокрушин, С.В. Кесян // Новые технологии, 2013. №4. - С. 61-67.

11. Тамов, А.А. Роль АПК в реализации региональных интересов / А.А. Тамов, М.К. Тамова // Вестник Адыгейского государственного университета. Серия 5: Экономика, 2014. № 2 (141). - С. 155.

12. Тамов, А.А. Инвестиционное обеспечение отраслей регионального АПК (на примере Республики Адыгея) // Пищевая промышленность, 2002. № 7. - С. 10. 


\title{
ФОРМИРОВАНИЕ БИЗНЕС-ГРУПП И ИХ ВОЗДЕЙСТВИЕ НА ЭКОНОМИКУ СТРАНЫ
}

Хатков М.A.

Адыгейский государственный университет, г. Майкоп

Научный руководитель: Мокрушин А.А.

д.э.н., профессор, Адыгейский государственный университет, г. Майкоп

\begin{abstract}
Аннотация: В статье раскрыты функциональное содержание, основные формы бизнесгрупп, механизмы формирования и источники финансирования бизнес-групп. Особое внимание уделено положительному и отрицательному влиянию бизнес-групп на экономику на макро-, мезо-уровнях.

Ключевые слова: бизнес-группа, финансово-промышленная группа, сетевая индустриальная структура, интегральная бизнес-группа.
\end{abstract}

\section{FORMATION BUSINESS GROUPS AND THEIR INFLUENCE ON THE NATIONAL ECONOMY}

Khatkov M.A. Adyghe State University, Maykop Research supervisor: Mokrushin A.A. Doctor of Economics, Professor, Adyghe State University, Maykop

\begin{abstract}
The article reveals the functional content, main forms of business groups, formation mechanisms and finance sources of business groups. Special attention is given to the positive and negative impact of business groups on the economy at the macro-, meso-levels.

Keywords: Business group, financial and industrial group, network industrial structure, integrated business group.
\end{abstract}

Одним из факторов устойчивого развития современной экономики ведущих стран мира является развитие хозяйственно й деятельности крупных бизнес-групп. Под бизнес-группой (БГ) понимается совокупность предприятий и организаций, действия которых выходят за рамки обычных контрактов на рынках товаров и заемного капитала, но происходят при сохранении статуса партнеров по группе как отдельных хозяйственных субъектов. К основным организационно-хозяйственным формам БГ в мировой практике относят: крупные компании, с дивизиональной структурой, холдинговые компании, финансовопромышленные групा, сетевые индустриальные организации.

В общем смысле под бизнес-группо й понимается совокупность предприятий и организаций, координация действий которых не сводится как к административ ной координации, так и обычным контрактам на рынках товаров и заемного капитала, но происходит при сохранении статуса партнеров по группе как отдельных (юридически или хозяйственно обособленных) экономических субъектов.

Интегрированной называется БГ с действующим на регулярной основе координацио нным центром. Роль такого центра может выполнять один из участников группы, клуб президентов, входящих в интегрированную бизнес-группу (ИБГ) компаний, общий собственник этих компаний и т.Д.

Финансово-промышленная группа представляет собой объединение нескольких компаний, включающих в свой состав на ряду 
с производственной, перерабатывающей, сервисной, транспортную компанию и финансово-кредитную организацию в виде банка, страховой компании и т.д. ФПГ в свою очередь могут быть созданы совершенно разными методами.

Ключевыми

способами

создания

интегрированных ФПГ являются: на основе механизмов холдинговой взаимозависимости; на основе координирующей роли центральной компании; на основе доверительного управления, где централь ная компания получает доверительно е управление имуществом участников; на основе объединения производственных ресурсов в капитале центральной компании путем их внесения в уставный капитал централь ной компании.

Разновидностью бизнес-группы является сетевая индустриальная структура (СИО), представляющая собой совокупность предприятий, объединенных связями на долговременных кооперационных

информационных основах. Одним из наиболее используемых видов СИО является контрактная группа, в которой в качестве механизма интеграции служат давальческие поставки сырья и/или соглашения между предприятиям и единой технологичес кой цепочки о применении «денежных суррогатов», к примеру, векселей [1].

В целом выделяют три группы способов создания интегрированных бизнес-групп:

- предоставление доступа к отдельным ресурсам и услугам; при этом заключается договор по централизованному снабжению ресурсами, сбыту готовой продукции. Предоставление доступа к ресурсам может осуществляться как путем предоставления производственных ресурсов, так и путем авансирования производственно хозяйственной деятельности, предоставления гарантий по кредитам перед банками и т.д.

\section{добровольная}

централизация

прав

управления деятельности; при этом создается управляющая структура, в рамках которой осуществляется реализация совместных интересов участников бизнес-группы;

- консолидация собственности, интеграцию на основе реорганизации путем слияния, поглощения, поглощения через банкротство, присоединения, выделения.

Интегрированные бизнес-группы оказывают как положительное, так и негативное влияние на экономику регионов и стран в целом. Основными положительными результатам и деятельности интегрированных бизнес-групп (на макро-уровне организации хозяйственных процессов) являются:

- снижение стоимости конечной продукции вследствие уменьшения затрат на промежуточную продукцию в результате решения проблемы «двойной маржинализации» - последовательного суммирования прибыли производителям и промежуточной и конечной продукции;

- уменьшение совокупных издержек и создание

общественно-нормаль но й структуры цены путем стимулирования платежеспособного спроса населения;

- мобилизация инвестиционных ресурсов, техническая реконструкция и модернизация производства [2];

- упорядочение системы взаиморасчетов взаимодействующих предприят ийучастников интегрированной бизнес-группы; - ускорение процесса концентрации инвестиционных ресурсов на приоритетных направления $\mathrm{x}$ развития экономики за счет развития механизма внутриотраслевого и межотраслевого перераспределения ресурсов; - более высокие темпы развития научнотехнического прогресса;

- либерализация внешнеэкономических связей за счет уменьшение зависимости 
страны от импорта.

Среди негативных последствий расширения присутств ия интегрированных бизнес-групп в экономике следует особо выделить:

- возможность трансформации рыночных структур в сторону снижения конкуренции;

$$
\text { развитие процессов }
$$

Моно-,

олигополизации товарных рынков;

- $\quad$ отсутствие четкой стратегии корпоративного развития большинства интегрированных бизнес-структур;

- внутренние (внутригрупповые) проблемы отсутствия или дефицита финансирования как следствие неопределенности в структуре собственности и неотработанности имущественных отношений между участниками интегрированной бизнесгруппы;

- неэффективность контроля и

управляемости, прозрачности

сбалансированности структуры;

- низкая эффективность работы центральной компании бизнес-группы; недостаточный уровень консолидации ресурсов в уставном капитале центрально й компании приводит к опоре только на неформальные связи с руководством членов группы, что негативным образом влияет на авторитет центральной компании [3];

- дополнительные расходы на координацию действий; существование корпоратив ных конфликтов [4].

При формировании интегрированных бизнес-групп в основном используются два механизма:

- первый состоит в постепенном установлении тесных связей между рядом промышленных предприятий

и

обслуживающими их крупными трейдерами и банками и взятии на себя последними некоторых управленческих функций, но без приобретения контрольных или даже блокирующих пакетов акций;
- второй механизм связан с широким применением механизмов банкротства. Управленческие бизнес-группы начинают формироваться путем включения на предприятиях-должниках процедуры внешнего управления и назначения на должность внешнего управляющего представителей кредиторов [5].

Главными источниками финансирования деятельности бизнес-групп являются инвестиционные кредиты банков-участников, финансирование из бюджета по целевым программам, кредиты и прямые инвестиции банков, не являющихся участниками данной бизнес-группы, собственные средства предприятий.

Мировой опыт свидетельствует о том, что бизнес-группы, включающие промышленные предприятия, исследовательские организации, торговые фирмы и банки, многие ассоциативные структуры, основанные на внутренних договорных отношениях, стали своеобразным каркасом рыночной экономики целого ряда стран. Именно на интраэкономическом уровне организации производственного потенциала обеспечиваются рациональные партнерские, договорные связи с государственным и органами, реализовывается подготовка, координация и контроль выполнения корпоративных планов и программ совместной деятельности ряда хозяйствующих субъектов. При этом начинае т действовать привлечение внешних инвесторов, разработка и реализация корпоративной стратегии деятельности на фондовом рынке, выполнение других управленческих функций, связанных с реализацией и защитой интерес ов акционеров.

В эффективной рыночной экономике интегрированные бизнес-группы выступают в виде ретрансляторов управляющего 
воздействия государства на микроэкономику.

Получается, повышается

уровень макроэкономического регулирования производства, обеспечивается устойчивость международного экономического сотрудничества. Бизнес-группы являются партнерами государства в выработке и реализации стратегии форсированно й модернизации экономики [6].

Таким образом, инициаторам создания интегрированных бизнес-групп необходимо оценить преимущественные стороны и тщательно взвесить возможные негативные пункты их функционирования, а потом решить, каким

образом

будут

инкорпорированы

основные участники группы с тем, чтобы уменьшить или устранить негативные эффекты существования бизнес-групп. Помимо определения положительных сторон, которые могут быть достигнуты при помощи интеграции, крайне необходима разработка методологического аппарата комплексного анализа эффективности бизнес-групп как на этапе предварительной оценки целесообразности ее формирования, так уже и в процессе функцио нирования.

\section{ЛИТЕРАТУРА}

1. Дементьев, В.Е. Введение в институциональную экономику: учеб. пособие - М.: Экономика, 2005 - С. 434-482.

2. Гумеров, Р. Вопросы развития интегрированных корпоративных структур в агропромышленном комплексе // Российский экономический журнал, 2002. № 5-6. - С. 24-34.

3. Ильин, М.С. Финансово-промышленная интеграция и корпоративные структуры: мировой опыт и реалии России / М.С. Ильин, А. Тихонов. - М.: Альпина паблишер, $2002,-287$ c.

4. Кузнецова, Т.В. Вестник Омского университета // Серия «Экономика», 2007. № 3.-C. 25-29.

5. Механизмы формирования интегрированных бизнес-групп и компаний. [Электронный peсурс]. - Режим доступа: http://uchebnik.online/organizatsiya-biznesaistoriya/mehanizmyi-formirovaniya-integrirovannyih-24679.html.

6. Финансово-промышленные группы. [Электронный ресурс]. - Режим доступа: http://www.bibliotekar.ru/teoriya-organizacii/139.htm.

7. Мокрушин, А.А Корпоративное управление интеграционными трансакциями в АПК региона: функциональные особенности, критерии эффективности / А.А. Мокрушин, С.В. Кесян // Новые технологии. 2013, №4. - С. 61-67.

8. Мокрушин, А.А. Способ структурной организации взаимодействия вертикально интегрированных корпораций с региональными экономическими системами Южного федерального округа // Известия Кабардино-Балкарского научного центра РАН, 2011. № 5. - C. 146-153.

9. Тамов, А.А. Моделирование регионального АПК как структурного подразделения экономики региона / А.А. Тамов, М.К. Тамова // Вестник Адыгейского государственного университета. Серия 5: Экономика, 2014. №2 (141). - С. 155.

10. Тамов, А.А. Особенности регионов и их влияние на межрегиональную агропродовольственную интеграцию // Никоновские чтения, 2010. № 15. - С. 89. 


\title{
ПРОБЛЕМЫ И ПЕРСПЕКТИВЫ РАЗВИТИЯ СЕТИ МНОГОФУНКЦИОНАЛЬНЫХ ЦЕНТРОВ ПРЕДОСТАВЛЕНИЯ ГОСУДАРСТВЕННЫХ И МУНИЦИПАЛЬНЫХ УСЛУГ В РЕСПУБЛИКЕ АДЫГЕЯ
}

Хуранов А. $А$. аспирант, Адыгейский государственный университет, г. Майкоп Научный руководитель: Мокрушин А.A. д.э.н., профессор, Адыгейский государственный университет, 2. Майкоп

\begin{abstract}
Аннотация: В данной статье рассмотрень результаты деятельности сети многофункцииональных иентров предоставления государственных и муниципальных услуг (МФЦ) в Республике Адыгея. Раскрыт потенцииал сети МФЦ в организации обслуживания населения, малого и среднего предпринимательства, в развитии конкурентной среды в Республике Адыгея, в повышении инвестищчонной привлекательности региона. Раскрыт комплекс организационных проблем функционирования сети МФЦ в Республике Адыгея, первоочередные задачи развития МФЦ.

Ключевые слова: сеть многофункциональных центров предоставления государственных и мунищипальных услуг (МФЦ), Республика Адыгея, инвестиционная привлекательность региона, конкурентная среда.
\end{abstract}

\section{PROBLEMS AND PROSPECTS OF DEVELOPMENT OF A NETWORK OF THE MULTIPURPOSE CENTERS OF PROVIDING THE STATE AND MUNICIPAL SERVICES IN THE REPUBLIC OF ADYGEA}

Khuranov A.A. Adyghe State University, Maikop Research supervisor: Mokrushin A.A. Doctor of Economics, professor, Adyghe State University, Maikop

\begin{abstract}
This article describes the results of activity of the network of the multipurpose centers of providing the state and municipal services $(M F C)$ in the Republic of Adygea. The potential of $M F C$ to the maintenance of the population, small and medium enterprises, the development of a competitive environment in the Republic of Adygea, in improving the investment attractiveness of the region was revealed. The complex organizational problems in the functioning of the MPs network in the Republic of Adygea, the priorities of IFC's development was revealed.

Keywords: network of the multipurpose centers of providing the state and municipal services (MFC), Republic of Adygeya, regional attractiveness, competitive environment.
\end{abstract}

В последние годы вопросам повышения эффективности деятельности органов государственной власти уделяется особое внимание. Одним из приоритетных направлений совершенствования системы государственного управления в РФ является повышение доступности и качества государственных и муниципальных услуг. В соответствии с Указом Президента Российской Федерации от 7 мая 2012 года № 601 «Об основных направлениях совершенствования системы государственного управления» (Указ
№ 601) доля граждан, имеющих доступ к получению государственных и муниципаль ны х услуг по принципу «одного окна» по месту пребывания к 2015 году должна была составлять не менее $90 \%$.

Одним из самых успешных проектов по повышению качества и доступности государственных и муниципальных услуг для граждан, реализованным за последние годы в России, является создание сети многофункциональных центров 
муниципальных услуг по принципу «одного окна» (МФЦ).

Создание сети МФЦ имеет значительные преимущества для граждан:

- снижение максимального срока ожидания в очереди при сдаче запроса и получении документа;

- сокращение сроков предоставления государственных и муниципальных услуг и количества документов, предоставляемых заявителями;

- возможность получить и государственные, и муниципальные услуги в одном месте с возможностью получения сразу нескольких услуг;

- отсутствие посредников на рынке государственных услуг;

- наличие квалифицированных и
профессиональных сотрудников, умеющих работать с клиентом;

- широкий спектр услуг: в МФЦ можно и оформить брак, и получить загранпаспорт, и оплатить налоги, и претендовать на оказание многих других услуг;

- обеспечение стандартов комфортности при предоставлении услуг для заявителей;

- бесплатность предоставления услуг; удобное территориальное размещение.

Безусловным фактором комфортности для населения является шаговая доступность офисов МФЦ. Так в Республике Адыгея помимо офисов, расположенных в административных центрах городов и районов, МФЦ есть и в каждом сельском поселении. Всего по республике находится 11 крупных центров и 40 удаленных рабочих мест. Доля граждан, имеющих доступ к услугам МФЦ, в среднем по Адыгее составляет более $97 \%$.

Учитывая, что прием граждан в МФЦ ведется универсальными специалистами, заявитель на приеме может получить ответы практически на все интересующие его вопросы. Все офисы МФЦ в Республике Адыгея выдержанны в едином фирменном стиле «Мои документы». В каждом помещении имеются зоны информирования, зоны ожидания в очереди, зоны приема документов. Кроме того, в офисах МФЦ для заявителей обеспечен доступ к Единому порталу государственных услуг и к сайтам органов власти.

Перечень услуг, предоставляемых в режиме «одного окна», увеличивается с каждым годом. Если в начале 2016 г. в МФЦ было организовано предоставление 162 государственных и муниципальных услуг, то на 1 января 2017 года их уже 230. Одновременно с внедрением новых услуг растет и количество обращений в МФЦ. За три последних годачисло оказанных в МФЦ услуг увеличилось почти в 3 раза, что говорит о популярности и значимости МФЦ для жителей республики. Для сравнения, в 2015 году посредством сети МФЦ было оказано 263989 услуг, а в 2016 году уже 423047 государственных и муниципальных услуг.

Важным фактором в деятельности МФЦ являются не только количественные показатели. Обеспечив для граждан доступность к государственным и муниципальным услугам по месту пребывания, сегодня главным приоритетом в деятельности МФЦ остается повышение качества услуг, предоставляемых в режиме «одного окна». При этом необходимо отметить, что граждане в МФЦ могут не только получить услуги, но и оценить качество их результата посредством CMC-опроса. Оценки поступают в федеральную информационно-аналитическую систему мониторинга качества государственных услуг «Ваш контроль». Из анализа оценок поступивших в указанную систему за 2016 год, следует, что 96\% заявителей удовлетворены качеством полученных в МФЦ услуг.

Вместе с тем в деятельности МФЦ в Республике Адыгея существует целый ряд проблем, непосредственно влияющих на его 
деятельность.

Главной

проблемой

деятельности МФР в республике является отсутствие на территории офисов МФЦ возможности приема от заявителей денежных средств в счет уплаты государственной пошлины или иной платы за предоставление государственных и муниципальных услуг, взимаемых в соответствии с законодательством Российской Федерации. Данное требование содержится в Правилах организации деятельности многофункциональных центров предоставления государственных и муниципальных услуг (далее - Правила), утвержденных постановлением Правительства Российской Федерации от 22 декабря 2012 года № 1376.

На сегодняшний день из 11 МФЦ в Республике Адыгея платежными терминалами оборудованы только 3 центра. $\mathrm{He}$ заинтересованность кредитных организаций в размещении на территории МФЦ Адыгеи информационно-платежных терминалов связана с низкой экономической эффективностью, вытекающей из доли услуг, предполагающих оплату госпошлины и ожидаемого объема платежей.

Правилами организации деятельности МФЦ также установлено, что МФЦ может выступать в качестве банковского платежного агента, однако до настоящего времени правовых механизмов реализации данного положения Правил налоговым законодательством не предусмотрено. По информации Минэкономразвития России вопрос возможности взимания с заявителей денежных счет уплаты государственной пошлины сотрудниками МФЦ рассматривается в Минфине России.
Одной
из
ключевых
проблем

функционирования МФЦ в Республике Адыгея является превышение времени ожидания заявителя в очереди при подаче запроса на предоставление услуги в некоторых филиалах

\section{МФЦ.}

Согласно пункту 18 Правил время ожидания не должно превышать 15 минут. Однако не во всех МФЦ указанное время выдерживается. Данное обстоятельство вызвано рядом объективных причин, связанных с массовыми наплывами посетителей в пиковые часы, увеличением времени на прием документов, обслуживанием заявителей в две смены, при котором одномоментная работа с утра до вечера всех окон МФЦ не представляется возможной.

$$
\text { Устранение вышеуказанных проблем }
$$
рассматривается приоритетным направлением развития деятельности МФЦ в Республике Адыгея в 2017г. Среди первоочередных задач управления сетью МФЦ в Республике Адыгея на 2017г. следует особо отметить:

- эффективная организация выездного обслуживания граждан с целью оказания им социально-значимых государственных и муниципальных услуг;

- создание на базе МФЦ окон для субъектов малого и среднего предпринимательства, в которых будут оказываться услуги для юридических лиц и индивидуальных предпринимателей. Следует отметить, что организация сети МФЦ для бизнеса способно усилить конкурентные преимущества Республики Адыгея в работе с инвесторами и повысить уровень деловой активности. Организация эффективной работы МФЦ с крупными корпоративными инвесторами рассматривается перспективным направлением роста инвестиционной привлекательности Республики Адыгея, фактором привлечения в регион корпоративных бизнес-групп (вертикально-интегрированных, диверсифицированных), новых торговых сетей. - участие сети МФЦ в выдаче, замене паспортов гражданина РФ. Так, предполагается полная передача полномочий по выдаче, замене паспортов гражданина РФ, удостоверяющих личность гражданина РФ на территории РФ, 
приему документов и выдаче водительских удостоверений при их замене или в случае утраты согласно постановлению Правительства РФ от 3 августа 2016 года № 755 «О внесении изменений в постановление Правительства Российской Федерации от 27 сентября 2011 года № 797»).

Развитие сети МФЦ, эффективная организация ее деятельности, грамотное межведомственное

функциональной

способствовать

государственных услуг, предоставляемых населению Республики Адыгея, субъектам малого и среднего предпринимательства, снижению уровня трансакционных издержек хозяйствующих субъектов, а также росту инвестиционной привлекательности региона.

\section{ЛИТЕРАТУРА}

1. Актуальные проблемы теории государства и права: учебное пособие, под ред. А. И. Бастрыкина. - М.: Юнити-Дана, 2014. - 471 с.

2. Федеральный закон «Об организации предоставления государственных и муниципальных услуг» от 27.07.2010г. № 210-ФЗ.

3. Указ Президента РФ «Об основных направлениях совершенствования системы государственного управления» от 07.05.2012г. № 601 .

4. Постановление Правительства РФ «Об утверждении Правил организации деятельности многофункциональных центров предоставления государственных и муниципальных услуг» от 22.12.2012г. № 1376.

5. Мокрушин, А.А. Стратегические приоритеты развития региональных экономических систем // Вестник Адыгейского государственного университета. Серия 5: Экономика, 2010. № 3 - С. 135 . 


\section{РАЗДЕЛ III}

\section{УЧЕТНО-ФИНАНСОВЫЕ АСПЕКТЫ ЭКОНОМИКИ}




\title{
ПРОБЛЕМЫ АУДИТОРСКОЙ ДЕЯТЕЛЬНОСТИ В РФ: СУЩНОСТЬ И ПУТИ РЕШЕНИЯ
}

Андрюхина Д.В., Бореева Е.P.

студентки, Адыгейский государственный университет, г. Майкоп

Научный руководитель: Таусова И.Ф.

к.э.н., доцент, Адыгейский государственный университет, г. Майкоп

\begin{abstract}
Аннотация: В статье рассмотрена ситуащия рынка аудиторских услуг в России в настоямее время. Выявлены проблемы среди числа аудиторских организаџий, трудности, связанные с качеством проведения аудита, с уменьшением аудиторских организаций, с отсутствием интереса к проведению инициативного аудита. Предложены пути решения выявленных проблем.

Ключевые слова: Аудит, рынок аудиторских услуг, саморегулируемые организации, аудиторские организации, аудиторы, качество аудита, обязательный аудит, инициативный аудит, проблемы аудита, пути их решения.
\end{abstract}

\section{PROBLEMS AUDIT ACTIVITIES IN THE RUSSIA FEDERATION:} ESSENCE AND SOLUTIONS

Andrukhina D.V., Boreeva E.R.

students, Adygei state university, Maikop Research supervisor: Tausova I.F. Cand.Econ.Sci., associate professor, Adygei state university, Maikop

\begin{abstract}
The article describes the situation of audit services market in Russia at the moment. The problems include the number of audit firms, the difficulties associated with audit quality, with a decrease in audit firms, the lack of interest to conduct proactive auditing. The ways of solving the problems identified.

Keywords: Audit, the market for audit services, self-regulatory organizations, audit firms, auditors, audit quality of statutory audit, initiative audit, audit issues, ways to solve them.
\end{abstract}

Возникновение аудита в России, являющегося одним из важнейших социально-эко номических институтов, связано с переходом к рыночной экономике и ее проблемами и трудностями.

Аудиторская деятельность в последние годы осуществлялась в соответствии с федеральными законами, а именно: от 30 декабря 2008 г. №307-Ф3 «Об аудиторской деятельности» [1] и от 1 декабря 2007 г. №315-Ф3 «О саморегулируемых организациях» [2], другими нормативно-правовыми актами, основывающимися на совмещении государственного и профессионального регулирования.
В России для обеспечения интересов аудиторской профессии создан Совет по аудиторской деятельности при Минфине. Закон №307-Ф3 установил состав Совета, количество которого 16 членов: десять представителей пользователей бухгалтерской (финансовой) отчетности, два представителя Минфина России, по одному представителю от Банка России и Минэкономразвития России и два представителя от СРОА). В настоящее время в РФ функционируют пять профессиональных аудиторских некоммерческих объединений: «Аудиторская палата России», «Инсти- 
тут профессиональных аудиторов», «Московская аудиторская палата», «Российская коллегия аудиторов» и «Аудиторская ассоциация Содружество». Федеральный закон №403-Ф3 [3] изменил требования к численности членов СРОА, что приведет к сокращению количества саморегулируемых организаций аудиторов. Это может оказать неблагоприя тное влияние на развитие рынка аудиторских услуг. Участникам этого рынка услуг необходимо выбрать до 01.01.2017 г. СРОА, членами которой они будут. В то же время СРОА определят, кто из них будет функционировать дальше, что поспособствует образованию нездоровой конкуренции между СРОА и, несомненно, скажется на качестве аудита.

При выборе СРОА и для вступления в нее аудитору необходимо узнать:

1. Имеет ли фирма право на осуществление подобной деятельности, т. е. включена ли она в Государственный реестр аудиторских организации, соответствует ли информация декларируемая на сайте СРОА, предоставленной на сайте Ростехнадзора.

2. Сколько в штате фирмы профессиональных аудиторов (их должно быть не менее трех), наличие у них действующих аттестатов, внутрифирменных стандартов, которые регламентируют проведение аудита.

3. Какое количество времени компания ведет свою деятельность (саморегулируемая организация должна существовать более 3-4 лет), имеется ли у компании страховой полис профессиональной ответственности.

4. Организована ли система контроля качества услуг, какова репутация организации, какое место она занимает в независимых рейтингах, имеются ли крупные клиенты.

5. Каков комплекс дополнительных услуг предоставляет аудиторская компания, каково местоположение аудиторской организации.

Для того чтобы не было нездоровой конкуренции между СРОА, необходимо, чтобы были решены следующие задачи, являющиеся важнейшими для развития добросовестной конкуренции в системе саморегулирования: осведомленность потребителя; открытость статей сравнения; независимость методик анализа.

Важной и актуальной проблемой в настоящее время является низкая конкурентоспособность большинства отечественных аудиторских организаций, отсутствие интереса к проведению инициативного аудита. Это связано с тем, что они не имеют необходимых финансовых, кадровых и иных ресурсов для обеспечения должного функционирования деятельности, системы внутреннего контроля аудиторских организаций и достижения целей аудиторской деятельности, существует сложность в частых изменениях бухгалтерского и налогового законодательства, что ставит под сомнение их потенциальную конкурентоспособность в целом.

Качество аудиторских услуг изменяется. Это происходит из-за сокращения количества аудиторов. В этой ситуации аудиторские организации сражаются за сохранение своего положения с помощью сокращения издержек и (или) предложения клиентам демпинговых цен. Они намного ниже рыночных цен, порой, не превышают себестоимость товара или услуги. Следствием этого выступает очень низкое качество аудита, что не удовлетворяет интересы как пользователей финансовой отчетности, так и общества в целом. Когда аудитор работает по таким ценам, он отчетливо понимает, что не сможет провести аудит на должном уровне, что в это время понимает и клиент, который перестает видеть смысл в проведении «поверхностного» аудита и не хочет за это платить. Неудовлетворительное качество аудита оправдывается его низкой ценой. Решение данное проблемы возможно с помощью усиления государственного регулирования аудита, установления государством 
фиксированных цен, которые находятся в разумных пределах, и контроля за проведением качества аудита.

Рассмотрим данные табл. 1, в которой представлена информация о количестве аудиторов и аудиторских организаций, которые имеют право на осуществление аудиторской деятельности за период 2013-2016 гг.

Данные табл.1 показывают, что количество аудиторских организаций и аудиторов за представленный период имеет негативную тенденцию к снижению. Количество аудиторов, которые сдали квалификационный экзамен на получение единого аттестата, за это время увечилось, не смотря на снижения количества аудиторов и аудиторских организаций в общем.

Обеспокоенность вызывают итоги анализа численности аудируемых лиц в динамике. В течение 2014-2015 гг. количество организаций, отчетность которых подлежала аудиторской проверке, сокращалось.

\section{Таблица 1 - Количество аудиторских организаций и аудиторов в РФ [4]}

\begin{tabular}{|l|c|c|c|c|c|}
\hline $\begin{array}{l}\text { Аудиторы } \\
\text { и аудиторские организации }\end{array}$ & 1.01 .13 г. & 1.01 .14 г. & 1.01 .15 г. & 31.12 .15 г. & 15.03 .16 г. \\
\hline $\begin{array}{l}\text { Имеют право на осуществление } \\
\text { аудиторской деятельности } \\
\text { - всего, тыс., в том числе: }\end{array}$ & 5,7 & 5,5 & 5,3 & 5,1 & 5,3 \\
\hline аудиторские организации & 4,8 & 4,7 & 4,5 & 4,4 & 4,5 \\
\hline индивидуальные аудиторы & 0,9 & 0,8 & 0,8 & 0,7 & 0,8 \\
\hline Аудиторы - всего, тыс. из них: & 24,1 & 23,0 & 22,2 & 21,5 & 21,3 \\
\hline $\begin{array}{l}\text { сдавшие квалификацио нный } \\
\text { экзамен на получение аттестата }\end{array}$ & 3,2 & 3,2 & 3,4 & 3,5 & 3,5 \\
\hline
\end{tabular}

Такая тенденция очень опасна для аудиторского сообщества, т. к. объемы и доходность деятельности аудиторов стремительно снижаются, но наибольший риск это представляет для потенциальных пользователей финансовой отчетности. У аудиторов появляется еще большая потребность в сохранении клиентов любой ценой, которая выступает в виде аудиторского заключения. Для наглядности рассмотрим табл. 2 .

\section{Таблица 2 - Распределение выданных аудиторских заключений по видам [4]}

\begin{tabular}{|l|c|c|c|c|}
\hline \multirow{2}{*}{ Вид аудиторского заключения } & \multicolumn{3}{|}{$\begin{array}{c}\text { Доля в общем количестве выданных } \\
\text { аудиторских заключений }\end{array}$} \\
\cline { 2 - 5 } & $\begin{array}{c}\text { по результатам } \\
\text { обязательного } \\
\text { аудита }\end{array}$ & \multicolumn{2}{|c|}{$\begin{array}{c}\text { по результатам } \\
\text { иницативного } \\
\text { аудита }\end{array}$} \\
\cline { 2 - 5 } & 2014 г. & 2015 г. & 2014 г. & 2015 г. \\
\hline Аудиторские заключения - всего, в том числе: & 100,0 & 100,0 & 100,0 & 100,0 \\
\hline с выражением немодифицированного мнения & 76,5 & 77,6 & 73,1 & 75,9 \\
\hline с выражением мнения с оговоркой & 22,6 & 21,6 & 24,3 & 21,3 \\
\hline с выражением отрицательного мнения & 0,5 & 0,5 & 1,6 & 1,8 \\
\hline с отказом от выражения мнения & 0,3 & 0,3 & 1,0 & 0,9 \\
\hline $\begin{array}{l}\text { Аудиторские заключения с выражением сомнения в возможности } \\
\text { клиента продолжать деятельность и с указанием на } \\
\text { значительную неопределенность в деятельности клиента }\end{array}$ & 3,2 & 3,8 & 2,5 & 3,0 \\
\hline
\end{tabular}


Согласно данным Минфина России [4], доля в общем количестве выданных немодифицированных аудиторских заключений по результатам проведения обязательного аудита в 2015 г. составила 77,6\% по сравнению с 2014 г. выросла на 1,1\%. По результатам инициативного аудита доля выданных немодифицированных аудиторских заключений в 2015 г. выросла почти на $3 \%$.

Также за этот период увеличивалась доля с выражением отрицательного мнения и отказом от выражения мнения по результатам инициативного аудита. Число аудиторских заключений с выражением мнения с оговоркойза 2014 2015 гг. наоборот снизилось.

В настоящий момент ни один действующий законодательный акт не содержит положений, которые предусматривают ответственность за нарушение требования проводить обязательный аудит. Пунктом 1 ст. 14 Федерального закона №402-Ф3 «О бухгалтерском учете» определено: аудиторское заключение уже не включается в годовую бухгалтерскую (финансовую) отчетность. Упоминанием о наличии такой необходимости является положение п. 2 ст. 18 этого закона, в котором указано, что аудиторское заключение входит в состав отчетности, которая подлежащей представлению в государственные органы статистики, т. е., годовой отчетности. Кодексом РФ об административ ных правонарушениях, установлена ответствен ность за непредставление или несвоевременное представление государственному органу аудиторского заключения организациями, которые обязаны проводить обязательный аудит. В случае нарушения положения этого кодекса, организация будет платить административный штраф, который может быть наложен на должностных лиц (руководителя и главного бухгалтера) в сумме 300-500 р.; на юридических лиц - от 3 до 5 тыс. p.

В законодательство необходимо внести изменения, которые предусматривают штрафы, пени за уклонение от проведения обязательного аудита. Их размер должен быть значительно больше средней стоимости проведения аудита в организации. При аудировании организации, аудиторам необходимо учитывать наличие аудиторского заключения за предыдущий год (когда аудит обязателен), что повлияет на модификацию аудиторского заключения.

\section{Таблица 3 - Основания для проведения аудита [4]}

\begin{tabular}{|c|c|c|}
\hline \multirow[t]{2}{*}{ Основание проведения аудита } & \multicolumn{2}{|c|}{$\begin{array}{c}\text { Доля в общем количестве про- } \\
\text { веденных аудитов, \% }\end{array}$} \\
\hline & 2014 г. & 2015 г. \\
\hline $\begin{array}{l}\text { Выдано аудиторских заключений - всего, в том числе по } \\
\text { результатам: }\end{array}$ & 100,0 & 100,0 \\
\hline а) обязательного аудита & 85,3 & 88,7 \\
\hline из них отчетности: & & \\
\hline открытых акционерных обществ & 20,4 & 19,9 \\
\hline $\begin{array}{l}\text { организаций, ценные бумаги которых допущены к обращению на } \\
\text { организованных торгах }\end{array}$ & 1,2 & 1,2 \\
\hline кредитных организаций & 1,5 & 1,2 \\
\hline страховых организаций и обществ взаимного страхования & 0,7 & 0,6 \\
\hline негосударственных пенсионных фондов & 0,2 & 0,2 \\
\hline 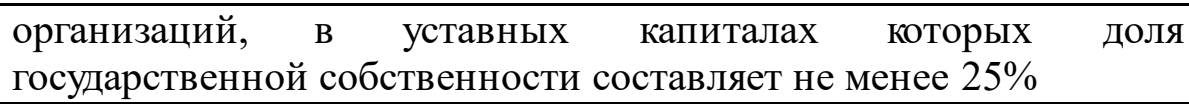 & 3,8 & 3,4 \\
\hline $\begin{array}{llll}\text { организаций, финансовые } & \text { показатели } & \text { которых } & \text { выше } \\
\text { минимальных значений } & & & \\
\end{array}$ & 50,5 & 49,7 \\
\hline б) инициативного аудита & 14,7 & 11,3 \\
\hline
\end{tabular}


Из вышеприведенной табл. 3 можно сделать вывод, что за период 2014-2015 гг. число аудиторских заключений, которые выданы по результатам обязательного аудита в общем количестве увеличилось и равно 88,7\%, когда в 2014 г. было 85,3\%. Но существует проблема снижения количества проведенного инициативного аудита с 14,7\% до 11,3\%.

К числу мер, которые направлены на преодоление вышеприведенных негативных тенденций, на наш взгляд, можно отнести: введение на законодательном уровне финансовой ответственности за уклонение от проведения обязательного аудита; улучшение качества аудиторских услуг; закрепление на законодательном уровне того периода времени, в течение которого клиент не сможет поменять аудитора; борьба с демпинговыми ценами на аудит; профессиональная подготовка и переподготовка аудиторов; предоставление налоговых льгот [8].

Таким образом, изучив статистические данные, характеризующие динамику рынка аудиторских услуг за период 2013-2016 гг., можно свидетельствовать о наличии тревожных фактов, которыми являются: уменьшение количества лиц, которые имеют право на осуществление аудиторской деятельности, неравномерность развития аудиторских организаций; значительное снижение количества аудируемых лиц, что приводит к уменьшению доходов аудиторов и пр. Все выше перечисленные факты свидетельствуют о формировании отрицательных тенденций развития аудита, который является гарантом в обеспечении общества необходимой достоверной и полной информацией о финансовом состоянии субъектов бизнеса.

\section{ЛИТЕРАТУРА}

1. Об аудиторской деятельности: федер. закон № 307-ФЗ от 30.12.2008 г. (в ред. от 03.07.2016 г.) // СПС КонсультантПлюс: версия Проф. - М., 2016.

2. О саморегулируемых организациях: федер. закон № 315 -ФЗ от 01.12.2007 г. (в ред. от 03.07.2016 г.) // СПС КонсультантПлюс: версия Проф. - М., 2016.

3. О внесении изменений в отдельные законодательные акты Росс ийской Федерации: федер. закон №403-Ф3 от 01.12.2014 г. // СПС КонсультантПлюс: версия Проф. M., 2016.

4. МИНФИН России, официальный сайт. [Электронный ресурс]. - Режим доступа: http://minfin.ru/ru/perfomance/audit/audit_stat/MainIndex/.

5. Анохова, Е.В. Саморегулирование аудиторской деятельности: современный этап // Аудиторские ведомости, 2011. №12. - С. 47-52.

6. Туббанов, А.В. Рынок аудиторских услуг России: тенденции, проблемы, направления развития / А.В. Туббанов, И. А. Лисовская // Деньги и кредит, 2015. № 2. - С. 14-20.

7. Таусова, И.Ф. Концепции аудиторской деятельности: задачи, проблемы, решения // Приоритетные научные направления: от теории к практике, 2015. - С. 173-175.

8. Шеремет, А.Д. Некоторые проблемы развития аудита в России // Аудит, 2014. № 9. - С. 24-27. 


\title{
СРАВНИТЕЛЬНЫЙ АНАЛИЗ РОССИЙСКОГО \\ И МЕЖДУНАРОДНОГО ПОДХОДОВ К УЧЕТУ \\ НАУЧНО-ИССЛЕДОВАТЕЛЬСКИХ \\ И ОПЫТНО-КОНСТРУКТОРСКИХ РАБОТ
}

Андрюхина Д.В., Бореева E.P.

студентки, Адыгейский государственный университет, г. Майкоп

Научный руководитель: Бекирова К.Н.

к.э.н., доцент, Адьгейский государственный университет, г. Майкоп

\begin{abstract}
Аннотация: В статье представлено сравнение российских и международных стандартов по учету научно-исследовательских и опытно-конструкторских работ. Выявлень в ходе анализа сходства и различия учета, изучено насколько российские стандарты учета НИОКР соответствуют международным стандартам.

Ключевые слова: Научно-исследовательские работы, учет НИОКР, международные стандарты, российские стандарты, анализ ПБУ и МСФО.
\end{abstract}

\section{THE COMPARATIVE ANALYSIS OF RUSSIAN AND INTERNATIONAL APPROACH TO ACCOUNTING RESEARCH AND DEVELOPMENT ACTIVITIES \\ Andrukhina D.V., Boreeva E.R. \\ students, Adygei state university, Maikop \\ Research supervisor: Bekirova K.N. \\ Cand.Econ.Sci., associate professor, Adygei state university, Maikop}

\begin{abstract}
The article compares the Russian and international standards of accounting research and development activities. Revealed during the analysis of the similarities and differences in accounting, studied how the Russian $R \& D$ accounting standards in line with international standards.

Keywords: Research and development, $R \& D$ accounting, international standards and Russian standards, RAS and IAS analysis.
\end{abstract}

Система бухгалтерского учета в России постоянно видоизменяется. Преобразование российского бухгалтерского учета согласно требованиям международных стандартов финансовой отчетности продолжается с принятия в марте 1998 г. Программы реформирования бухгалтерского учета в России в соответствии с МСФО (Постановление Правительства №283) и по настоящее время [3]. Несмотря на совершенствование российского учета, и его постепенное сближение с международными стандартами, проблемы адаптации сохраняются.

Нематериальные активы, законченные обработкой, давшие положительные результаты и зарегистрированные как НИОКР, учитываются в Российской Федерации согласно ПБУ 17/2002 «Учет расходов на НИОКР» [5], в МСФО вопросы учета НИОКР регулируется стандартом МСФО (IAS) 38 «Нематериальные активы» [6]. Научно-исследовательские и опытно-конструкторские работы - это комплекс работ, которые направлены на получение новых знаний и практическое примене ние при создании нового изделия или технологии.

Проведем дальнейшее сравнение, рассмотрев таблицу 1, которая содержит полный перечень анализируемых статей. 
Таблица 1 - Сравнение ПБУ 17/2002 и МСФО (IAS) 38 [5, 6]

\begin{tabular}{|c|c|c|}
\hline Наименование & $\begin{array}{l}\text { РСБУ } \\
\end{array}$ & МСФО \\
\hline $\begin{array}{l}\text { Сфера применения } \\
\text { стандарта }\end{array}$ & $\begin{array}{l}\text { Распространяется на результаты, нахо- } \\
\text { дящиеся под защитой закона, но не за- } \\
\text { регистрированные в соответствии с за- } \\
\text { конодательством и на полученные р-- } \\
\text { зультаты, которые не подлежат право- } \\
\text { вой охране в соответствии с нормами } \\
\text { действующего законодательства. }\end{array}$ & $\begin{array}{l}\text { Расходы на НИОКР рассматриваются } \\
\text { в качестве НМА при создании самой } \\
\text { организацией. Стандарт может приме- } \\
\text { няться к затратам на рекламу, пуско- } \\
\text { вые работы, подготовку, исследова- } \\
\text { ния и разработки. }\end{array}$ \\
\hline Определения & $\begin{array}{l}\text { К НИР относятся работы, связанные с } \\
\text { проведением экспериментальных раз- } \\
\text { работок и научно-исследовательской, } \\
\text { научно-технической деятельности. }\end{array}$ & $\begin{array}{l}\text { НИОКР является одним из способов } \\
\text { создания нематериального актива, ко- } \\
\text { торый рассматривается как идентифи- } \\
\text { цируемый неденежный актив без фи- } \\
\text { зической формы. }\end{array}$ \\
\hline $\begin{array}{l}\text { Оценка после при- } \\
\text { знания }\end{array}$ & $\begin{array}{l}\text { Расходы на НИОКР определяются из } \\
\text { сумм первостепенно оцененных затрат } \\
\text { за вычетом списанных расходов на от- } \\
\text { четную дату. }\end{array}$ & $\begin{array}{l}\text { Оценка нематериального актива мо- } \\
\text { жет проводиться одной из двух форм: } \\
\text { учет по себестоимости (себестон- } \\
\text { мость минус накопленная амортиза- } \\
\text { ция и убытки от обесценения) или по } \\
\text { переоценке (справедливая стоимость } \\
\text { на дату переоценки минус накоплен- } \\
\text { ная амортизация и убытки от обесце- } \\
\text { нения). }\end{array}$ \\
\hline $\begin{array}{l}\text { Срок полезного ис- } \\
\text { пользования }\end{array}$ & $\begin{array}{l}\text { Организация самостоятельно опреде- } \\
\text { ляет срок списания расходов, в зависи- } \\
\text { мости от срока использования полу- } \\
\text { ченных результатов НИОКР, в течение } \\
\text { которого организация может извлекать } \\
\text { доход, но не более пяти лет. }\end{array}$ & $\begin{array}{l}\text { Компания определяет срок эксплуата- } \\
\text { ции самостоятельно созданного нема- } \\
\text { териального актива (ограничен он или } \\
\text { неограничен). Неограниченным срок } \\
\text { - когда нет прогнозируемого предела } \\
\text { периода поступления финансовых ре- } \\
\text { сурсов от этого актива. }\end{array}$ \\
\hline $\begin{array}{l}\text { Метод начисления } \\
\text { амортизации }\end{array}$ & $\begin{array}{l}\text { Линейный; уменьшаемого остатка; } \\
\text { списания стоимости пропорциональ но } \\
\text { объему продукции (работ). }\end{array}$ & $\begin{array}{l}\text { Линейный; уменьшаемого остатка; } \\
\text { производственный способ. }\end{array}$ \\
\hline $\begin{array}{l}\text { Начало начисления } \\
\text { амортизационных } \\
\text { отчислений }\end{array}$ & $\begin{array}{l}\text { Амортизация будет начисляться с пер- } \\
\text { вого числа месяца, следующего за ме- } \\
\text { сяцем принятия этого актива к бухгал- } \\
\text { терскому учету. }\end{array}$ & $\begin{array}{l}\text { Амортизация начинается с того мо- } \\
\text { мента, когда местоположение и состо- } \\
\text { яние обеспечивают возможность его } \\
\text { использования }\end{array}$ \\
\hline $\begin{array}{l}\text { Прекращение } \\
\text { начисления амор- } \\
\text { тизационных } \text { от- } \\
\text { числений }\end{array}$ & $\begin{array}{l}\text { Амортизационные отчисления завер- } \\
\text { шаются с первого числа месяца, следу- } \\
\text { ющего за месяцем погашения всей сто- } \\
\text { имости или списания актива с бухгал- } \\
\text { терского учета. }\end{array}$ & $\begin{array}{l}\text { Амортизация прекращается в моменг } \\
\text { окончания даты его признания или } \\
\text { признания данного актива как предна- } \\
\text { значенного для продажи }\end{array}$ \\
\hline $\begin{array}{l}\text { Прекращение ис- } \\
\text { пользования и вы- } \\
\text { бытие }\end{array}$ & $\begin{array}{l}\text { Прекращение применения в производ- } \\
\text { стве или для управленческих нужд } \\
\text { компании, когда наглядно неполуче- } \\
\text { ние будущих доходов от использова- } \\
\text { ния результатов НИОКР, сумма расхо- } \\
\text { дов, не отнесенная на расходы по } \\
\text { обычным видам деятельности, списы- } \\
\text { вается на расходы от прочих видов де- } \\
\text { ятельности отчетного периода на мо- } \\
\text { мент принятия решения о прекраще- } \\
\text { нии использования результатов дан- } \\
\text { ной работы. }\end{array}$ & $\begin{array}{l}\text { Признание прекращается при выбы- } \\
\text { тии и когда от эксплуатации или вы- } \\
\text { бытия не ожидается никаких доходов. } \\
\text { Результат от выбытия - чистые по- } \\
\text { ступления от выбытия (если имеются) } \\
\text { минус балансовая стоимость актива. } \\
\text { Признается в составе прибылей и } \\
\text { убытков и не учитывается как вы- } \\
\text { ручка. }\end{array}$ \\
\hline
\end{tabular}


Таким образом, изучив таблицу 1 , можно сделать следующие выводы:

Во-первых, в ПБУ 17/02 расходы на НИОКР являются самостоятельным учетным объектом, который не пересекается с объектами нематериальных активов. ПБУ и МСФО не распространяются на расходы по освоению природных ресурсов.

Во-вторых, в российском учете результатом НИР является научный отчет, опытно-конструкторские технологические работы представляют собой завершенный обработкой и действующий экземпляр изделия, полный состав необходимой документации, технологических работ - описание новейшей технологии подходящей для использования. В МСФО 38 в состав расходов на НИОКР входят расходы, совершенные на этапах исследования и разработки. В ПБУ 17/02, этап исследований научно-исследовательским работы, а этап разработок - опытно-конструкторские и технологические работы.

В-третьих, в МСФО требования к раскрытию информации о нематериальных активах намного обширнее, чем в российских стандартах. В месте с тем, своеобразные раскрытия, требуемые МСФО для НИОКР не таких детализированные, чем правила раскрытия информации в ПБУ.

В-четвертых, МСФО предусмотрена переоценка объектов НИОКР, при которой восстанавливается часть расходов, понесенных на стадии исследований. Одновременно, учитывается индивидуальный характер НИОКР. В ПБУ переоценка НИОКР не предусмотрена.

В-пятых, расходы на НИОКР в ПБУ формально не являются амортизируемыми объектами, но порядок их списания аналогичен амортизации. В ПБУ 17/02 срок списания расходов составляет пять лет, в МСФО объект НМА не амортизируется. МСФО (IAS) 38 содержит более детальные указания при определении срока полезного использования.

В-шестых, в ПБУ начисление амортизации происходит с 1 числа месяца следующего замесяцем принятия актива, а в МСФО амортизация начисляется с того момента, когда определено местоположение объекта и возможно использовать объект. Прекращение амортизации в ПБУ это 1 число месяца следующего замесяцем прекращения признания актива, а в МСФО это дата продажи актива или дата прекращения признания актива.

В-седьмых, при продаже результатов НИОКР в учете по ПБУ 17/02 отражаются доходы и расходы от этой продажи, что соответствует подходу МСФО 38.

Подводя итог сравнения, следует отметить, что не столько велики расхождения с МСФО 38 «Нематериальные активы» по вопросам состава, переоценки объектов нематериальных активов, срока полезного использования, способа начисления амортизации, регламентации учетной информации в бухгалтерской отчетности. Сравнивая критерии признания нематериальных активов по НИОКР по правилам российских стандартов бухгалтерской отчетности и МСФО, можно увидеть, что важнейшие критерии идентичны, но нормы МСФО 38 распространяются только на НИОКР, имеющие характер разработок с момента обоснования проекта и начала работ.

В последние годы проводится действенные мероприятия по сближению российских стандартов и требований МСФО. Имеются определенные успехи, но предстоит еще проделать многое для окончательного устранения всех противоречия. 


\section{ЛИТЕРАТУРА}

1. Гражданский Кодекс Российской Федерации (часть четвертая): Федеральный закон от 18.12.2006 г. №230-Ф3 (в ред. от 03.07.2016 г.) // СПС КонсультантПлюс. Москва, 2016.

2. Международный стандарт финансовой отчетности (IAS) 38 «Нематериальные активы» (ред. от 17.12.2014) (введен в действие на территории Российской Федерации Приказом Минфина России от 25.11.2011 №160н) // СПС КонсультантПлюс. Москва, 2016.

3. Налоговый Кодекс Российской Федерации (часть вторая): Федеральный закон от 05.08.2000 г. №117-Ф3 (ред. от 19.05.2010 г.) // СПС КонсультантПлюс. - Москва, 2016.

4. Об утверждении Программы реформирования бухгалтерского учета в соответствии с международными стандартами финансовой отчетности: Постановление Правительства РФ №283 от 06.03.1998 // СПС КонсультантПлюс. - Москва, 2016.

5. Положение по бухгалтерскому учету «Учет нематериальных активов» (14/2007): Приказ Минфина России от 27.12.2007 №153н (ред. от 16.05.2016) // СПС КонсультантПлюс. - Москва, 2016.

6. Положение по бухгалтерскому учету «Учет расходов на научно-исследовательские, опытно-конструкторские и технологические работы» (17/2002): Приказ Минфина РФ от 19.11.2002 г. №115н (с изменениями и дополнениями) // СПС КонсультантПлюс. - Москва, 2016.

7. Багова, С.А. Историческая роль дисконтированной стоимости в системе бухгалтерского учета / С.А. Багова, К.Н. Бекирова, И.Г. Панженская // Экономика и предпринимательство, № 10 (ч.2), 2015 г. - С. 805-808. 


\title{
МЕЖДУНАРОДНЫЙ ПОДХОД К ПОДГОТОВКЕ ФИНАНСОВОЙ ОТЧЕТНОСТИ ОРГАНИЗАЦИЙ СТРОИТЕЛЬНОЙ ОТРАСЛИ
}

Бекирова К.Н. к.э.н., доцент, Адыгейский государственный университет, г. Майкоп магистрант, Адыгейский государственньй университет, г. Майкоп

\begin{abstract}
Аннотация: В статье раскрывается порядок подготовки и представления финансовой отчетности в соответствии с международными стандартами финансовой отчетности, выявлены особенности применения МСФО в строительной отрасли. Определены состав финансовой отчетности и периодичность ее подготовки, обязательные требования к представлению и раскрытию информации строчтельными компаниями.

Ключевые слова: строчтельство, строчтельная отрасль, отчетность, МСФО, международные стандарты, выручка.
\end{abstract}

\section{INTERNATIONAL APPROACH TO PREPARATION OF THE FINANCIAL REPORTING OF THE ORGANIZATIONS OF THE CONSTRUCTION INDUSTRY}

Bekirova K.N.

Cand.Econ.Sci., associate professor, Adygei state university, Maikop

Tkharkakhova M.N.

magistrate, Adygei state university, Maikop

\begin{abstract}
In article the order of preparation and accounts presentation according to the international accounting standards reveals, features of application of IFRS in a construction industry are revealed. The structure of the financial reporting and frequency of its preparation, mandatory requirements to representation and disclosure of information by real estate development companies are determined.
\end{abstract}

Keywords: construction, construction industry, reporting, IFRS, international standards, revenue.

Строительство - одна из материалоемких отраслей производственной деятельности, потребляющая огромные объемы строительных материалов и изделий. Бухгалтерский учет в строительных организациях является одним из проблемных направлений современного учета. Предмет бухгалтерского учета в капитальном строительстве - хозяйственная деятельность подрядных строительно-монтажных, проектных предприятий и застройщиков - предприятий, осуществляющих капитальные вложения.

Составление финансовой отчетности по Международным стандартам предполагает соблюдение основополагающих правил, которые определяют общий подход к подготовке и представлению финансовых отчетов. Це- лью финансовой отчетности по МСФО является предоставление информации о финансовом положении и результатах деятельности компании. Эта информация нужна широкому кругу пользователей при принятии экономических решений. Международные стандарты финансовой отчётности представляют собой совокупность документов (стандартов), регламентирующих правила составления финансовой отчётности, необходимой внешним и внутренним пользователям для принятия ими экономических решений в отношении предприятия. Для описания самых общих правил составления и представления финансовой отчетности изначально был принят первый из стандартов - MCФО (IAS) 1 «Представление финансовой отчетности». 
Bce большему количеству российских строительных компаний необходимо составлять финансовую отчетность не только по российским правилам бухгалтерского учета, но и по международным стандартам.

Международные стандарты финансовой отчетности базируются на таких основополагающих принципах составления отчетности, как требования к качеству информации, принципы отражения информации в учете и элементы финансовой отчетности.

Требования к качеству информации определяют те характеристики, которыми должна обладать информация, формируемая в системе финансового учета и представляемая в финансовой отчетности. Данные качества в первую очередь обусловлены необходимостью удовлетворения потребностей внешних пользователей финансовой отчетности. Требования к качеству информации определяются полезностью, уместностью, своевременностью, существенностью, достоверностью, надежностью, правдивостью, преобладанием содержания над формой, возможностью проверки, нейтральностью, понятностью, сопоставимостью и стабильностью.

Принципы учета информации определяют те правила, в соответствии с которыми должна отражаться информация в системе финансового учета.

Элементы финансовой отчетности представляют собой основные части финансовой отчетности - классы статей, которые обладают одинаковыми экономическими характерис тиками и группируются соответствующим образом в системе финансового учета и в финансовой отчетности.

МСФО (IAS) 1 «Представление финансовой отчетности» определяет полный комплект финансовой отчетности:

- Отчет о финансовом положении на дату окончания периода (бухгалтерский баланс) - данное название более точно отражает цели подготовки этой формы отчетности;

- Отчет о прибылях и убытках и прочих компонентах совокупного финансового результата за период;

- Отчет об изменениях в собственном капитале за период;

- Отчет о денежных потоках за период;

- Примечания, состоящие из основных положений учетной политики и прочей пояснительной информации;

- Сравнительную информацию за предшествующий период.

Финансовая отчетность должна представляться, как минимум, ежегодно. Международные стандарты требуют составления финансовой отчетности не реже раза в год, но не содержат понятия «отчетная дата». МСФО требуют от организации только обеспечения сопоставимости представляемой информации, то есть отчетные периоды должны повторяться от одной отчетности к другой.

Помимо финансовой отчетности строительным компаниям рекомендовано представлять пользователям «Промежуточную финансовую отчетность» в соответствии с МСФО 34. Промежуточная финансовая отчетность содержит набор финансовых отчетов за период более короткий, чем полный отчетный год данной организации.

MCФО (IFRS) 1 «Первое применение МСФО» является первым стандартом. Организация должна применять МСФО (IFRS) 1, если представленная финансовая отчетность за предшествующий наиболее поздний период:

— была подготовлена в соответствии с национальными требованиями, которые не совпадают со всеми МСФО;

- отвечает всем требованиям МСФО, но не содержит ясного и безоговорочного заявления об этом соответствии; 
- содержала специальное заявление о частичном соответствии МСФО;

— была составлена не только в соответствии с национальными стандартами, но и с некоторыми (но не всеми) МСФО;

- соответствовала национальным требованиям, представляя сверку отдельных показателей с аналогичными показателями, полученными с использованием МСФО.

Одной из главных задач бухгалтерского учета в строительной деятельности является достоверное определение доходов и расходов по каждому отчетному периоду. Методы, в соответствии с которыми должны признаваться затраты, доходы и определяться финансовый результат по выполненному объему работ за отчетный период, регламентирует МСФО (IFRS) 15 «Выручка по договорам с покупателЯМИ〉.

С новым стандартом MCФО (IFRS) 15 «Выручка по договорам с покупателями» существенно поменялись требования в отношении признания выручки по договорам на строительство, а также насколько новые правила, содержащиеся в MCФО (IFRS) 15, который приходит на смену МСФО (IAS) 11 «Договоры на строительство», помогут снизить субъективность используемых в нем оценок. Все организации должны будут применять новый стандарт по выручке $\mathrm{MCФO} \mathrm{(IFRS)}$ 15 при подготовке финансовой отчетности за годовые периоды, начинающиеся с 1 января 2018 года, но также возможно его досрочное применение с раскрытием данного факта в примечаниях к финансовой отчетности.

В рамках данного стандарта можно выделить следующие этапы использования модели признания доходов:

1. Идентификация договоров с клиентами.

MCФО (IFRS) 15 позиционирует договор как «соглашение между двумя или несколькими сторонами, которое обуславливает обеспеченные правовой защитой права и обязательства» [2].

Договор может быть письменным, устным либо вмененным.

Критерии, касающиеся самого контракта: форма подписанного соглашения; идентификация прав каждой из сторон в контексте оказываемых услуг; оговорка условий платежа и самой квоты вознаграждения; определение вероятности получения вознаграждения (вероятности реализации экономических выгод).

2. Идентификация контрактных обязательств исполнения.

MСФО (IFRS) 15 позволяет признавать доход в момент исполнения организацией обязательства. Обязательство исполнения - это оговоренные в договоре товары либо услуги, которые можно четко идентифицировать, и от которых заказчик (клиент) может получить выгоду независимо либо в сочетании с другими доступными для заказчика ресурсами.

3. Оговорка цены транзакции.

Чтобы признать доход, строительная организация должна быть в состоянии оговорить вознаграждение за обещанные по договору услуги либо товары. Цена транзакции может представлять собой фиксированную квоту либо переменную, зависящую от дополнительных уступок или бонусов, премий и так далее. Доходы, согласно стандарту, должны отражать квоты, получения которых ожидает организация, если она имеет право на их получение в рамках контракта - а не квоты, которые вообще влияют на ее баланс. Дополнительно, если договор содержит существенный элемент финансирования, необходимо также оговорить влияние изменений денежной стоимости с течением времени в форме корректировки цены транзакции (требование необяза- 
тельное, если время, которое проходит с момента оказания услуги до осуществления платежа, меньше одного года).

4. Отнесение цены транзакции на обязательства исполнения по договору.

В случае идентификации более чем одного обязательства исполнения в рамках одного контракта новый стандарт требует отнесения цены транзакции на каждый элемент (обязательство). Осуществлять это распределение нужно на основе относительных индивидуальных цен продажи. Лучшим основанием для определения индивидуальной цены является цена, по которой организация может отдельно продать данный товар либо услугу. В случае отсутствия возможности определение цены для организации действует обязательство оценки индивидуальной цены продажи с максимальным использованием наблюдаемых данных (например, скорректированная оценка рынка, прогнозные затраты плюс маржа). Остаточная методика может использоваться только в исключительных случаях.

5. Признание доходов по мере исполнения обязательств.

Обязательство считается исполненным в момент передачи заказчику контроля над услугой либо товаром, являющимися предметом договора. Суть контроля определяется как возможность непосредственного использования и экспроприации остающихся выгод от данной составляющей активов.

6. Признание доходов с течением времени или в момент исполнения обязательства.

Согласно стандарту МСФО (IFRS) 15, организация признает доходыс течением времени, если она постепенно передает с течением времени контроль над товаром либо услугой и тем самым исполняет свое обязательство. Это будет иметь место, только если выполнено хотя бы одно из следующих условий:
— клиент (заказчик) одновременно получает и пользуется выгодами, возникающими в результате оказания услуги организацией, в той мере как та исполняет свои обязательства;

- в результате исполнения обязательства организацией возникает либо оказывается улучшенной составляющая активов (например, продукция в процессе производства), а контроль над этой составляющей активов - по мере ее возникновения либо улучшения - осуществляет клиент, либо

- в результате исполнения обязательства организацией не возникает составляющей активов с альтернативным вариантом использования для организации (например, строящиеся активы являются очень специфичными и в значительной степени приспособленным и под нужды конкретного заказчика), а кроме того, у организации есть исполнимое право на оплату за досрочное исполнение обязательства.

Новый стандарт MCФО (IFRS) 15 не содержит основ автоматического признания доходов с течением времени в соответствии со степенью реализации, однако на практике стандартные соглашения можно составлять на прежних основах, если будут выполнены критерии, оговоренные в целях признания доходов с течением времени.

Строительные компании часто оказывают услуги, связанные со строительством либо улучшением уже существующих активов, которые находятся в распоряжении заказчико в (строительство на участке земли заказчика, ремонт существующих инсталляций и так далее), а дополнительно подписанное соглашение часто накладывает ограничения на альтернативный способ использования либо передачи создаваемых активов (страховка для заказчика). Однако ключевым с точки зрения стандартов МСФО (IFRS) 15 будет анализ положений существующих соглашений (в частности, в случае нестандартных договоров) с 
целью определения, не существуют ли предпосылки для отсутствия возможности признать доходы с течением времени (например, договорные ограничения, касающиеся получения активов). В таком случае доходы могут быть признаны только в определенный момент времени фактической реализации обязательства исполнения в полном объеме.

\section{ЛИТЕРАТУРА}

1. Международный стандарт финансовой отчетности (IAS) 1 «Представление финансовой отчетности» (ред. от 27.06.2016) (в веден в действие на территории Российской Федерации Приказом Минфина России от 28.12.2015 №217н) // СПС КонсультантПлюс. - Москва, 2016.

2. Международный стандарт финансовой отчетности (IFRS) 15 «Выручка по договорам с покупателями» (введен в действие на территории Российской Федерации Приказом Минфина России от 27.06.2016 №98н) // СПС КонсультантПлюс. - Москва, 2016.

3. Киржинова, К.Н. Актуальные проблемы формирования бухгалтерской отчетности российских компаний в соответствии с требованиями МСФО / К.Н. Киржинов а, Д.И. Понокова // Сборник научных трудов SWorld. - Вып. 3. Т. 34. - Одесса: КУПРИЕНКО СВ, 2013. - С. 38-42.

4. Михоровский, Л. Отчетность организаций строительной отрасли в соответствии с IFRS 15 с 1 января 2018 г. // GAAP.RU: теория и практика управленческого учета [режим

http://gaap.ru/articles/Otchetnost_organizatsiy_stroitelnoy_otrasli_v_sootvetstvii_s_IFR S_15_s_1_yanvarya_2018_g/.

5. Ордынская, М.Е. Проблемы применения международных стандартов финансовой отчетности в России // Финансовый менеджмент, учет и контроль с использованием современных информационных технологий: Материалы Международной научно практической конференции. - Орел: ОрелГТУ, 2001. - С. 32-33. 


\title{
АМОРТИЗАЦИЯ АКТИВОВ КАК ЭКОНОМИЧЕСКАЯ КАТЕГОРИЯ
}

Бюсунаева А.М. магистрант, Адыгейский государственный университет, г. Майкоп

Ордынская М.E. канд. экон. наук, доцент Адыгейский государственный университет, г. Майкоп

\begin{abstract}
Аннотация: В статье рассмотрено содержание категории «амортизация», ее функции, проанализирована действующая нормативно-правовая база, регулирующая вопросы начисления и учета амортизациии активов организациии.

Ключевые слова: амортизачия, основные средства, нематериальные активы.
\end{abstract}

\section{DEPRECIATION OF THESE ASSETS AS AN ECONOMIC CATEGORY}

Bzhunaeva AM. undergraduate, Adyghe State University, Maikop Ordynskaya M.E.

Cand. Econ.Sci., associate professor, Adygei state university, Maikop

\begin{abstract}
The article considers the content of the "amortization" category, its function, analyzed the existing legal framework, regulating the issues of charging and accounting for depreciation of assets of organization.

Key words: depreciation, fixed assets, intangible assets.
\end{abstract}

Проблема начисления амортизации затрагивается в большом количестве нормативных документов, однако в них не приводится четкого определения данного понятия.

В таблице 1 обобщим основные нормативные документы, регулирующие учет амортизации активов организации.

Таким образом, можно сделать вывод о том, что нормативные документы используют понятие амортизации, но не раскрывают сущности данной экономической категории. Что касается МСФО, то в них раскрываются понятие амортизации и амортизируемой стоимости.

В большинстве экономических источников термин «амортизация» переводят с латинского как «погашение», но встречается и иная интерпретация как «отрицание смерти» [3, с. 364]. Такая интерпретация воспроизводит главную идею расчета амортизации, которая заключается в возможности воспроизводственного процесса основных средств. С точки зрения Еременко Т.В., амортизация произошла от латинского «убивать» [2]

Амортизация относится к традицио нным бухгалтерским объектам, является популярной категорией, в связи с чем, в современной экономической литературе существует множество различных ее определений. Рассмотрим основные из них.

Есть авторы, которые избегают давать определение амортизации, они цитируют нормативные документы, полагая, что сущность этой категории очевидна. Этого подхода придерживаются в своих работах, например, Гетьман В.Г., Захарьин В.Р., Кондраков Н.П.

Многие трактуют амортизацию как некую процедуру, обеспечивающую постепенный перенос стоимости основных активов на изготавливаемую продукцию для возмещения затрат на их приобретение и строительство. Такая позиция изложена в работах многих авторов, например, Шеремета А.Д., Широбокова В.Г., в экономическом словаре под редакцией Азириля на А.Н. 


\section{Таблица 1 - Нормативно-правовые акты, регулирующие вопросы начисления и учета амортизации}

\begin{tabular}{|c|c|}
\hline Нормативный документ & Рассматриваемые аспекты \\
\hline $\begin{array}{l}\text { Статья } \\
\text { «Амортизируемое } \\
\text { имущество» НК РФ }\end{array}$ & $\begin{array}{l}\text { Амортизируемым имуществом считается имущество, результаты } \\
\text { интеллектуальной деятельности и другие объекты интеллектуальной } \\
\text { собственности, находящиеся у организации на праве собственности, } \\
\text { применяемые для извлекания дохода, стоимость которых погашается } \\
\text { посредством начисления амортизации. К амортизируемому имуществу } \\
\text { относят имущество со СПИ свыше } 12 \text { мес. и первоначальной } \\
\text { стоимостью более } 100 \text { тыс. р. [7] } \\
\text { Понятие амортизации не дано, сущность не раскрыта. }\end{array}$ \\
\hline $\begin{array}{l}\text { Раздел III «Амортизация } \\
\text { основных средств» ПБУ } \\
6 / 01 \text { «Учет основных } \\
\text { средств». }\end{array}$ & $\begin{array}{l}\text { Стоимость объектов погашается начислением амортизации. } \\
\text { Не амортизируются объекты, потребительские свойства которых со } \\
\text { временем не изменяются (например, земельные участки; объекты } \\
\text { природопользования и др.). [8] } \\
\text { Сущность амортизации также не определяется }\end{array}$ \\
\hline $\begin{array}{l}\text { Раздел IV «Амортизация } \\
\text { основных } \quad \text { средств» } \\
\text { Методических указаний по } \\
\text { бухгалтерскому у учету } \\
\text { основных средств }\end{array}$ & $\begin{array}{l}\text { Стоимость объектов, находящихся у организации на правах } \\
\text { собственности, хозяйственного ведения, оперативного управления (в } \\
\text { том числе объекты, которые переданы в аренду, безвозмездное } \\
\text { пользование, доверительное управление), погашают путем начисления } \\
\text { амортизации. Не амортизируются те объекты, потребительские } \\
\text { свойства которых со временем не меняются (например, земельные } \\
\text { участки, объекты природопользования). .[6] } \\
\text { Таким образом, в данном нормативном документе всего лишь } \\
\text { дублируется текст ПБУ 6/01.[8]. }\end{array}$ \\
\hline $\begin{array}{lr}\text { Раздел IV } \\
\text { «Амортизация } \\
\text { нематериальных } \\
14 / 2007 \quad \text { активов» } \\
\text { нематериальных активов» }\end{array}$ & $\begin{array}{l}\text { Стоимость НМА с определенным СПИ погашают путем начисления } \\
\text { амортизации в течение всего СПИ. По НМА с неопределенным СПИ } \\
\text { амортизацию не начисляют.[9] } \\
\text { Определение амортизации здесь не дается. }\end{array}$ \\
\hline $\begin{array}{ll}\text { МСФО (IAS) } & 16 \\
\text { «Основные средства» } & \end{array}$ & $\begin{array}{l}\text { По амортизацией понимается систематическое распределение } \\
\text { амортизируемой величины актива на протяжении всего СПИ. } \\
\text { Амортизируемой величиной признается первоначальная стоимость } \\
\text { актива или иная величина, принимаемая за первоначальную стоимость, } \\
\text { за минусом ликвидационной стоимости актива.[5] }\end{array}$ \\
\hline
\end{tabular}

Есть конщепщия, основанная на определении амортизации как денежного выражения износа основных средств. То есть амортизация и износ в данной трактовке являются практически синонимами. Данное определение, например, содержится в Современном экономическом словаре под редакцией Райзберга Б.A.

Есть трактовка, определяющая амортизацию как элемент издержек. Например, Шатунова Г.А. рассматривает амортизацию как включение в затраты производства изношенной части основных средств [10, с. 56].
Под амортизацией понимается та часть расходов, которая декапитализируется в отчетном году [2].

Следует отметить, что трактовка амортизации как элемента затрат традиционна для отечественной системы учета. В соответствии с данным подходом, амортизация в виде отчислений включается в себестоимость продукции.

Как экономическая категория амортизация призвана выполнять такие функции, как:

- денежное возмещение износа активов; 
- формирование издержек на производство и продажу продукции;

- инвестирование на простое и расширенное воспроизводство;

- определение налогооблагаемой прибыли;

- экономическое обоснование инвестиций;

- предотвращение полного морального и физического износа активов.

Обобщая вышесказанное, амортизацию можно описать как учетно-экономический процесс, включающий:

1) постепенный перенос стоимости активов на себестоимость продукции или расходы отчетного периода;

2) создание источника финанс ирования воспроизводства активов при переходе амортизационных отчислений в денежную форму.

По сферам выделяют финансовую, фискальную и учетную амортизацию.

Финансовая амортизация применяется в финансовых расчетах, включая управленческий учет. Фискальная амортизация применяется в налоговом учете при исчислении налоговой базы по налогу на прибыль. Учетная амортизация применяется в финансовом учете.

По объектам можно выделить амортизацию основных средств, НМА, природных ресурсов (как истощение).

Выделяют экономическую, финансовую и налоговую, инвестиционную концепции амортизации.

Экономическая

конщепция амортизации связана с затратным подходом; подразумевается, что амортизация является средством распределения затрат во времени. Финансовая конщепция связана с использованием высвобождаемого денежного капитала на инвестирование. Налоговая конщепция предполагает рост денежного капитала вследствие уменьшения налогооблагаемой базы по налогу на прибыль. Инвестиционная концепция предполагает образование собственного внутреннего источника финансирования инвестиционной деятельности посредством аккумуляции амортизационных отчислений и увеличения их доли в источниках финансирования инвестиций в основной капитал $[1, \mathrm{c}$. 42].

По равномерности можно выделить линейную, исчисляемую с линейной зависимостью и ускоренную, исчисляемую по увеличенно й норме [4, с. 12].

Поскольку амортизация является одним из элементов себестоимости продукции, то она влияет на величину себестоимости и финансовый результат деятельности организации.

Обобщая вышесказанное, можно сделать вывод о том, что амортизация это комплексное понятие, затрагивающие различные аспекты деятельности организации.

\section{ЛИТЕРАТУРА}

1. Веретенникова, О.Б. Амортизационные отчисления как форма собственных источников финансирования инвестиций / О.Б. Веретенникова, 3.М. Бикметова // Известия УрГЭУ. - 2011. № 6(38). - С. 41-44.

2. Говдя, В.В. Стратегический учет амортизации в агропромышленных формированиях / В.В. Говдя, Т.А. Силина // Нормативные акты для бухгалтера. - 2007. № 10. - С. 21-24.

3. Еременко, Т.В. Концепция амортизации О. Шмаленбаха // Финансы и бизнес. -2010. № 3. - C. 160-172.

4. Ковалев, В.В. Финансовая отчетность. Анализ финансовой отчетности (основы балансоведения): учеб. пособие. - М.: ТК Велби, Изд-во Проспект, 2006. - 432 с. 
5. Медведев, М.Ю. Бухгалтерский словарь. - М.: ТК Велби, Изд-во Проспект, 2008.496 с.

6. Международный стандарт финансовой отчетности (IAS) 16 «Основные средства»: приказ Минфина РФ от 18.12.2015 г. №217н // СПС КонсультантПлюс. - Москва, 2016.

7. Методические указания по бухгалтерскому учету основных средств: приказ Минфина РФ от 13.10 .03 г. № 91 н: (в ред. от 24.12.10 г.) // СПС КонсультантПлюс. Москва, 2016.

8. Налоговый кодекс Российской Федерации (часть вторая): Федеральный закон от 5.08.2000 г. №117-Ф3 (в ред. от 06.04.15 г.) // СПС «КонсультантПлюс». - Москва, 2016.

9. Положение по бухгалтерскому учету «Учет основных средств» (ПБУ 6/01): приказ Минфина РФ от 30.03.2001 г. №26н: (в ред. от 16.05.2016 г.) // СПС КонсультантПлюс. - Москва, 2016.

10. Положение по бухгалтерскому учету «Учет нематериальных активов» (14/2007): приказ Минфина РФ от 27.12.2007 г. №153н: (в ред. от 16.05.2016 г.) // СПС КонсультантПлюс. - Москва, 2016.

11. Шатунова, Г.А. Бухгалтерский финансовый учет в схемах и таблицах / Г.А. Шатунова, Т.А.Корнеева, Н.А. Архипова. - М.: Эксмо, 2010. - 512 с. 


\title{
АКТУАЛЬНЫЕ ВОПРОСЫ ПЕНСИОННОГО ОБЕСПЕЧЕНИЯ В СОВРЕМЕННЫХ УСЛОВИЯХ
}

Бзегенсева С. $\boldsymbol{A}$. учашчаяся, МБОУ СОШ №1, а.Кошехабль

Научный руководитель: Седзева Р.X. учитель истории и обществознания, а.Кочехабль

\begin{abstract}
Аннотация: В статье рассматриваются основные виды пенсии, выявлены условия их назначений. Автор показывает, что в современной России каждый человек может повлиять на свою будущую пенсию.

Ключевые слова: пенсия по старости, страховая пенсия, корпоративная пенсия, Пенсионный фонд России.
\end{abstract}

\section{TOPICAL ISSUES OF PROVISION OF PENSIONS IN MODERN CONDITIONS}

Bzegezheva S.A. becoming frequent, No. 1 MBOU SOSh, Koshekhabl Research supervisor: Sedzeva R. Kh. teacher of history and social science, Koshekhabl

\begin{abstract}
In article main types of pension are considered, conditions of their appointments are revealed. The author shows that in modern Russia each person can affect the future pension. Keywords:. old-age pension, insurance pension, corporate pension, Pension Fund of the Russian Federation.
\end{abstract}

Молодость это время, когда не думаешь о старосте. Время неумолимо бежит и мы приближаемся к пенсионному возрасту. Рано или поздно мы столкнемся с этим. Обстоятельства жизни на пенсии - лучшая оценка результата той трудовой и социальной жизни, в которую человек скоро вступает.

На сегодняшний день изменился порядок формирования пенсии, сравнительно со временем наших родителей. Сегодня пенсия - это не пособие по старости от государства, одинаковое для всех. Начиная работать молодые люди в наше время могут влиять на размер своей будущей пенсии.

Вступая во взрослую жизнь, человек вступает в трудовые отношения. Это начало длинного пути формирования будущей пенсии. По каким правилам она формируется, какими способами ее можно увеличить - это необходимо знать уже в молодости, чтобы потом не сожалеть об упущенных возможностях.
Пенсия - это ежемесячная денежная выплата, назначенная указанным в законе лицам в качестве основного источника средств к существованию в установленных случаях.

Вплоть до XIX века пенсионное обеспечение носило избирательный характер и проявлялось в качестве милости царствующей особи к подчиненным. Пенсии назначались войнам, защищающим княжеские, царские владения.

На сегодняшний день существуют следующие виды пенсий:

- страховая пенсия;

- пенсия по государственному обеспечению;

- накопительная пенсия;

- пенсия по негосударственному обеспечению.

Страховая пенсия - ежемесячная денежная выплата для компенсации гражданам заработной платы или другого дохода, которые они получали в период трудовой деятельности, а также компенсация дохода, который утратили 
нетрудоспособные члены семьи застрахованного лица в связи с его смертью.

К страховой пенсии устанавливается фиксированная выплата в твердом размере, которая зависит от вида страховой пенсии. Размер выплаты ежегодно индексируется государством.

Существует три вида страховой пенсии:

- страховая пенсия по старости;

- страховая пенсия по инвалидности;

- страховая пенсия по случаю потери кормильца.

Страховая пенсия по старости начисляется при достижении гражданином Российской Федерации статуса пенсионера. Пенсионный возраст в России был установлен еще в 1932 году и с тех пор ни разу не подвергался изменению. Пенсионный порог для женщин составляет 55 полных лет и 60 лет для мужского населения. Необходимый трудовой стаж для оформления полноценной пенсии 25 лет для мужчин и 20 для женщин. Сейчас идет разговор о повышении планки пенсионного возраста.

Страховую пенсию по инвалидности получают те, кто ограничен в трудовой деятельности из-за серьезных проблем со здоровье, а не по возрасту.

Страховая пенсия по случаю потери кормильца - это ежемесячная выплата, назначаемая нетрудоспособным членам семьи умершего кормильца в качестве частичной компенсации помощи, которая является для них постоянным и основным источником средств существования.

Потерей кормильца считается его смерть (или безвестное отсутствие), подтвержденное соответствующими документами или решением суда в соответствии с ГК РФ.

На сегодняшний день, страховую пенсию по старости - основной вид пенсии в России - получают 35,5 миллиона человек.

Выделяется 5 видов пенсий по государственному обеспечению:
- по старости;

- по случаю потери кормильца;

- по инвалидности;

- социальная пенсия.

Государственная пенсия - это ежемесячная денежная выплата, которая оплачивается гражданам Россииза счетгосударства(из средств Пенсионного фонда) согласно Ф3 «О государствен ном пенсионном обеспечении в Российской Федерации».

Пенсия за выслугу лет назначается:

- федеральным государственным служащим;

- военнослужащим;

- гражданам из числа космонавтов;

- работникам летно-испытательного состава.

Государственная пенсия по старости назначается тем гражданам, которые имеют страховой стаж и достигли пенсионного возраста, установленного государством.

Государственная пенсия по случаю потери кормильца могут получать:

- члены семей военнослужащих и лиц, ним приравненных;

- члены семей тех граждан, которые пострадали в результате катастрофы на Чернобыльской АЭС, а также в результате других радиционных или техногенных катастроф;

- члены семей граждан из числа космонавтов.

Государственная пенсия по инвалидности назначается:

- военнослужащим;

- гражданам, пострадавшим в результате радиационных или техногенных катастроф;

- участникам Великой Отечественной войны;

- гражданам, награжденным знаком «Жителю блокадного Ленинграда»;

- космонавтам.

Социальная пенсия назначается нетрудоспособным гражданам, постоянно проживающим в Российской Федерации. На данный момент социальную пенсию получают 3,1 млн. россиян.

- за выслугу лет; 
Средства, из которых формируют накопительную пенсию, называют пенсионными накопителями. Они в большей степени напоминают средства банковского вклада. В соответствии с определением, используемым ПФ РФ, под накопительной пенсией понимается денежная сумма, формируемая из страховых взносов работодателя и дохода от их успешного инвестирования, и выплачиваемая каждый месяцпосле выхода на пенсию до конца жизни. Именно в возможности инвестирования заключается главное отличие накопительной пенсии от страховой - если страховая пенсия находится в ведении исключительно ПФ РФ и Внешэкономбанка, то накопительная доля может быть переведена в другие УК.

Право на накопительную пенсию имеют не все, но любой совершеннолетний гражданин вправе добровольно формировать свое будущее обеспечение, перечисляя на свой лицевой счет страховые взносы. Кроме этого, дается право выбора страхователя: граждане могут формировать свои накопления в негосударственном пенсионном фонде (НПФ) или в управляющей компании государственного Пенсионного фонда (ПФР).

Также застрахованные лица имеют право менять как управляющую компанию, так и сами фонды. Но при этом важно помнить о том, что более длительный период управления страховщиком средствами накоплений является более выгодным для застрахованного лица. Размер выплаты данной пенсии рассчитывается исходя из выбранного застрахованным лицом вида выплаты.

Негосударственное пенсионное обеспечение (НПО) также называют добровольным пенсионным обеспечением. Чтобы получать пенсию по НПО, нужно заключить соответствующий договор с негосударственным пенсионным фондом и осуществлять добровольные взносы на протяжении периода, предусмотренного договором. В формировании негосударственного пенсионного обеспечения может участвовать не только гражданин, но и его работодатель. Корпоративная пенсионная система основывается на принципе долевого участия работника и работодателя в формировании будущей пенсии работника (например, ОАО «РЖД»). Отчисления, которые делает работодатель на добровольную пенсию своего работника - корпоративная пенсия. Корпоративные пенсионные программы на сегодняшний день являются одним из элементов социально - партнерских отношений между работодателем и работником, и становятся все более актуальными для общества и государства.

Около 7 миллионов человек в России участвуют в программах негосударственного пенсионного обеспечения.

\section{Обратимся к цифрам:}

- 42,7 млн. человек получают пенсию по обязательному пенсионному страхованию в Пенсионном фонде России.

- 60 млн. россиян формируют пенсию по обязательному пенсионному страхованию.

- 5 млн. россиян ежегодно становятся участниками системы обязательного пенсионного страхования.

- 6,1 млн. страхователей уплачивают взносы на обязательное пенсионное страхование.

- 26,5 млн. человекполучают социальные выплаты и другие меры государственной поддержки в Пенсионном фонд России.

- 2,5 млн. человек формируют дополнительную пенсию с государственной поддержкой.

- 13,2 тыс. руб. в месяц составляет средний размер самой распространенной в России страховой пенсии.

Итак, чтобы сформировать достойную пенсию нужно сделать 7 шагов.

1 шаг. Получить СНИЛС и использовать его возможности. Уже с детства у нас имеется индивидуальный лицевой счет с уникальным страховым номером-СНИЛС. Снилс это ключ к получению социальных государственных 
услуг в электронном виде. Он пригодиться не только владельцу, но и его семье.Например, для более быстрого получения гражданского или заграничного паспорта.

2 шаг. Нужно работать только там, где платят «белую» зарплату. Когда человек выходит на постоянную работу он начинает участвовать в системе обязательного пенсионного страхования. Очень важно получать официальную зарплату. Именно с нее страхователи начисляют взносы в Пенсионный фонд России.

3 шаг. Зарабатывать страховой стаж. Чем больше стаж-тем выше будет пенсия.

4 шаг. Выбрать свой вариант пенсионного обеспечения. Когда человек начинает работать, он должен выбрать, стоит ли формировать накопительную пенсию в системе ОПС. Чтобы принять решение у него есть пять лет с начала трудовой деятельности. Но нужно помнить о главных отличиях в принципах формирования страховой и накопительной пенсий:

- страховая пенсия каждый год, как правило, гарантированно увеличивается государством;

- при вложении средств пенсионных накопителей может быть не только прибыль, но и убытки.

5 шаг. Нужно участвовать в добровольных nенсионных программах. Человек может стать участником программ добровольного пенсионного страхования. А его результатом будет дополнительная пенсия, которая будет выплачивать негосударственные пенсионные фонды за счет добровольных взносов - твоих или твоего работодателя.

6 шаг. Контролировать состояние своегопенсионного счета. Можно получить сведения в личном кабинете на электронном портале Пенсионного фонда es.pfrf.ru и на портале электронных государственных услуг www.gosuslugi.ru или получить выписку со своего пенсионного счета через банк.

И наконец, 7 шаг. Не нужно спешить выходить на пенсию. Ведь, если выйти позже на пенсию, то она в дальнейшем будет тебе назначена в повышенном размере. Если обратиться за страховой пенсией через 5 лет после возникновения права на нее, то размер пенсии будет примерно на 40\% больше.

Если говорить о состоянии и перспективах развития пенсионного обеспечения в Республике Адыгея, необходимо отметить следующее. Постановлением Правления Пенсионного фонда РСФСР от 29.04.1991 года №85 было создано Отделение Пенсионного фонда РСФСР по Адыгейской автономной области. Тогда в короткие сроки была укомплектована профессиональными кадрами служба уполномоченных по сбору страховых взносов в ПФР.

Уже в 2005 году Указом Президента Республики Адыгея от 12 декабря 2005 года № 98 за особые заслуги в области социального развития Республики Адыгея ГУ - Отделение ПФ РФ по Республике Адыгея было награждено медалью «Слава Адыгеи». Позже Отделение ПФР по Республике Адыгея еще не раз признавалось лучшим учреждением социальной сферы не только в Адыгее, но и за ее пределами. Например, по итогам работы за 2013 год Отделение ПФР по Республике Адыгея было признано «Лидером Пенсионного фонда Российской Федерации», а по итогам работы за 2012 и 2014 годы Отделение ПФР по Республике Адыгея было удостоено дипломов «Лучшее Отделение ПФР в Южном Федеральном округе».

В составе Отделения ПФР по Республике Адыгея - 8 управлений ПФР : в г. Майкопе, Гиагинском, Кошехабльском, Красногвардейском, Майкопском, Тахтамукайском, Теучежском и Шовгеновском районах, а также Отдел ПФР в г. Адыгейске. Во всех территориальных органах ПФР Республики Адыгея созданы оснащенные по последнему слову техники и укомплектованные высокопрофессиональными кадрами клиентские службы, оказывающие широкий перечень услуг населению, в том числе и информа- 
ционных. С апреля 2010 г. успешно обслуживает жителей отдаленных населенных пунктов республики хорошо зарекомендовавшая себя мобильная клиентская служба ПФР.

По данным на 1 октября 2016 г. пенсии и иные социальные выплаты за счет средств Пенсионного фонда получает 126226 жителей Республики Адыгея, что составляет $28,0 \%$ от общей численности населения региона (451480 чел.). Наибольшее количество пенсионеров Республики Адыгея проживает в г. Майкопе - 38,7\% от общей численности, наименьшее - в Шовгеновском районе $(3,8 \%)$ и в г. Адыгейске $(3,4 \%)$.

Всего в регионе зарегистрировано 529873 застрахованных лица и 445776 актуальных лицевых счетов. Численность получателей ежеме- сячных денежных выплат по Республике Адыгея составляет 43005 человек. Численность получателей федеральной социальной доплаты к пенсии в Республике Адыгея составляет 21640 человек. С начала реализации Программы государственной поддержки семей, имеющих детей, государственный сертификат на материнский (семейный) капитал получили 25718 жителей республики. Средний размер пенсии в республике составляет 11 568,99 руб.

В условиях современного информационного общества вопрос пенсионного обеспечения актуален для каждого человека. Будучи финансово просвещенным, грамотный человек имеет возможность увеличить свою будущую пенсию. Ведь каждый человек должен позаботиться о своей пенсии сам.

\section{ЛИТЕРАТУРА}

1. Зурабов, М.Ю. Выплата пенсий в России. - М.: ЮНИТИ, 2007. - 587с.

2. Государственная пенсия [Электронный peсурс]. - Режим доступа: http://vsetemu.org/new-gosudarstvennaya-pensiya.html.

3. Зурабов, М.Ю. Копи пенсию смолоду //Российская газета. - 1 апреля, 2007. - С.4.

4. Карпенко, С.В. Обязательные взносы индивидуальных предпринимателей во внебюджетные фонды Российской Федерации: история и современность / С.В. Карпенко, Т.А. Силина, М.Е. Ордынская // Финансы и кредит, 2014. №37(613) - С. 1122.

5. Карпенко, С.В. Платежи индивидуальных предпринимателей во внебюджетные фонды российской федерации / С.В. Карпенко, Т.А. Силина, М.Е. Ордынская // Мир науки и инноваций, 2015. № 2 (2) Том 9-С. 71-74.

6. Карпенко, С.В. Учетные аспекты перехода плательщиков взносов во внебюджетные фонды к уплате единого социального налога / С.В. Карпенко, Т.А. Силина, М.Е. Ордынская // Nauka i studia, 2016. T. 4. - C. 121-123.

7. Зурабов, М.Ю. Пенсионная реформа в России. - М.: ЮНИТИ, 2006. - 790с.

8. Пенсионное планирование: Что делать с накопительной частью трудовой пенсии? [Электронный ресурс]. - Режим доступа: http://www.ypensioner.ru/pensionnoeplanirovanie-chto-delat-s-nakopitelnoy-chastyu-trudovoy-pensii.

9. Илюхина, О.Е. Способы выплаты пенсии. - М.: Просвещение, 2005. - 540с.

10. Соловьёв, А. К. Финансовая система государственного пенсионного страхования в России. - М.: Финансы и статистика, 2006. - 598c. 


\title{
КЛАССИФИКАЦИЯ И УЧЕТ ЗАТРАТ НА БЛАГОУСТРОЙСТВО ТЕРРИТОРИИ И ПРИОБРЕТЕНИЕ МНОГОЛЕТНИХ НАСАЖДЕНИЙ В САНАТОРНО-КУРОРТНЫХ ОРГАНИЗАЦИЯХ И ОРГАНИЗАЦИЯХ ГОСТИНИЧНОГО БИЗНЕСА \\ Кондратенко А.В. студент, Кубанский государственный университет, г. Краснодар Научный руководитель: Костюкова И.Н. к. э. н., доиент, Кубанский государственный университет, г. Краснодар
}

\begin{abstract}
Аннотация. В статье рассматриваются особенности классификации затрат и признания их в качестве расходов в цеелях их отражения в бухгалтерском учете и отчетности. $B$ санаторно-курортных организациях и организациях гостиничного бизнеса, данный вид затрат напрямую связан с основной деятельностью и направлен на получение доходов.

Ключевые слова: затраты на благоустройство, многолетние насаждения, бухгалтерский учет затрат на благоустройство, расходыл.
\end{abstract}

\section{CLASSIFICATION AND ACCOUNTING OF COSTS FOR AREA IMPROVEMENT AND ACQUISITION PERENNIAL PLANTS \\ IN THE HEALTH RESORT AND HOTEL BUSINESS}

Kondratenko A.V. student, Kuban state university, Krasnodar Research supervisor: Kostyukova I.N. cand. econ. sci., associate professor, Kuban state university, Krasnodar

\begin{abstract}
The article discusses the features of the classification of expenses and recognize them as expenses for the purposes of accounting and reporting. In the sanatorium-resort institutions and hotel business, this cost element is directly connected with the main activity and is aimed at the income.

Key words: costs of landscaping, perennial plantings, accounting costs landscaping costs.
\end{abstract}

Благоустройство территории - это важная составляющая дорожного, жилищного и гражданского строительства. Благоустройство территории - комплекс мероприятий по инженерной подготовке и обеспечению безопасности, озеленению, устройству покрытий, освещению, размещению малых архитектурных форм и объектов монументального искусства.

Виды санаторно-курортных учреждений определены номенклатурой медицинских организаций. К ним относятся санатории, санатории-профилактории, курортные поликлиники, грязелечебницы, бальнеологические лечебницы, санаторные оздоровительные лагеря круглогодичного действия.
В качестве объектов гостиничного бизнеса выступают объекты, предоставляющие клиентам услуги по размещению, проживанию и отдыху.

Благоустройство прилегающей территории признается важным условием для успешного функционирования учреждений санаторнокурортного и гостиничного типа, ведь именно от благоприятного впечатления и отзывов клиентов зависит дальнейшее процветание таких организаций.

Чтобы экономически грамотно определить общую сумму расходов, направленных на благоустройство территории, расходы группируются по экономическим элементам и калькуляционным статьям. Элементами благоустройства признаются: 
- элементы инженерной подготовки и защиты территории;

- озеленение;

- виды покрытий;

- сопряжения поверхностей;

- ограждения;

- малые архитектурные формы;

- игровое и спортивное оборудование;

- освещение и осветительное оборудование;

- средства наружной рекламы и информации;

- некапитальные нестацио нарные сооружения;

- оформление и оборудование зданий и сооружений;

- площадки;

- пешеходные коммуникации;

- транспортные проезды.

В номенклатуру статей затрат относят следующие текущие расходы на:

- содержание штата рабочих, обслуживающих сады и парки;

- оформление стендов, благоустройство цветников и клумб, уход за парковыми и садовыми дорожками;

- посадку цветов и декоративных однолетних растений и уход за ними;

- оснащение территории санатория;

- текущий ремонт объектов благоустройства.

Важное значение имеет квалификация затрат в целях их отражения в бухгалтерском учете и отчетности в качестве приносящих экономические выгоды активов. Учет объектов зависит от вида деятельности организации; так как в данной статье рассматривается учет расходов на благоустройство в санаторно-курортных организациях и организациях гостиничного бизнеса, данный вид затрат напрямую связан с основной деятельностью и направле н на получение доходов. Объект учитывается на счете 01 «Основные средства», если подходит под условия определения объекта основных средств согласно ПБУ №6/01 «Учет основных средств».

Принимая во внимание специфику учета расходов в гостиницах и санаториях, к таким объектам могут относиться асфальтированные дорожки и дорожки, мощенные плиткой, система уличного освещения, спортивные площадки, ограждения, многолетние насаждения и др. Также к объектам основных средств внешнего благоустройства можно отнести скульптуры, фонтаны, клумбы, цветники, гроты, в стоимость которых включаются закладка камня, насыпка гравия, подготовка почвы, проведение систем водоснабжения и т.д. Все объекты подлежат амортизации, если подходят под определение основного средства и используются для обеспечения комфортных условий отдыхающим.

Операции по благоустройству территории признаются затратами на приобретение объектов внешнего благоустройства и (или) их сооружение может производиться с помощью подрядных организаций или собственными силами. В случае приобретения и (или) сооружения объектов основных средств внешнего благоустройства с помощью подрядных организаций оформляются записи:

Дебет 08 «Вложения во внеоборотные активыл»

Кредит 60 «Расчеты с поставщчиками и подрядчиками».

Отражение НДС по приобретенным объектам оформляется записью:

Дебет 19 «Налог на добавленную стоимость по приобретенным иченностям»

Кредит 60 «Расчеты с поставщиками и подрядчиками».

При сооружении объекта внешнего благоустройства собственными силами оформляется запись:

Дебет 08 «Вложения во внеоборотные активыл» 
Кредит 23 «Вспомогательное производство», 20 «Основное производство», 25 «Общепроизводственные расходы», 26 «Общехозяйственные расходы» 10 «Материаль»», 70 «Расчеты с персоналом по оплате труда».

Принятие к учету объектов внешнего благоустройства осуществляется на основании акта о приеме-передаче объекта основных средств и оформляется записью:

\section{Дебет 01 «Основные средства»}

Кредит 08 «Вложения во внеоборотные активьи».

Однако, если объекты удовлетворяют критериям для их признания в качестве основных средств, но их стоимость составляет менее сорока тысяч рублей, то целесообразно учитывать объекты благоустройства в качестве материально-про изводственных запасов. Ими могут быть такие объекты учета, как саженцы деревьев, семена декоративных цветов, малые архитектурные формы, небольшие деревянные ограждения, спортивное оборудование (мячи, теннисные ракетки), хозяйственный инвентарь для ухода за озелененными участками (тяпки, грабли, лопаты). Если организация находится в прибрежной зоне, то в качестве материально-про изводственных запасов она имеет право признать шезлонги, пляжные зонты и другое оборудование, специфич ное для морского отдыха. Приобретение данных объектов оформляется записью:

\section{Дебет 10 «Материаль»»}

Кредит 60 «Расчеть с поставщикками и подрядчиками».

Отражение НДС по приобретенным материально-производственным запасам:

Дебет 19 «Налог на добавленную стоимость по приобретенным изенностям»

Кредит 60 «Расчеты с поставщчиками и подрядчиками».

В расходах на благоустройство значительную долю занимают затраты на посадку и вы- ращивание многолетних декоративных растений. В связи с тем, что многолетние насаждения относятся к объектам основных средств и подлежат амортизации, следует затраты по выращиванию до смыкания крон отражать на счете 01 «Основные средства» с открытием субсчета «Многолетние насаждения». После завершения процесса смыкания возможен ввод многолетних насаждений в эксплуатацию.

Основанием для отражения этих операций служат промежуточные и итоговые акты по приему многолетних растений и вводу их в эксплуатацию.

Многолетние насаждения оформляются карточкой учета, где отражается информация о местоположении, годе посадки, даты и номера акта приема, годе сдачи в эксплуатацию и балансовой стоимости. Аналитический учет многолетних насаждений ведется по видам насаждений. Отражение затрат на закладку и выращивание многолетних насаждений производится записью:

Дебет 01 «Основные средства», субсчет "Многолетние насаждения»

Кредит 08 «Вложения во внеоборотные активьl».

Начисление амортизации на объект многолетних насаждений оформляется:

Дебет 20 «Основное производство», субсчет «Растениеводство»

Кредит 02 «Амортизачия основных средств».

Списание балансовой стоимости многолетних насаждений при утрате производственного значения:

Дебет 01 «Основные средства», субсчет 11 «Bыбытие основных средств»

Кредит 01 «Основнье средства», субсчет «Многолетние насаждения».

Списание амортизационных отчислений по списываемым многолетним насаждениям:

Дебет 02 «Амортизация основных средств» 
Кредит 01 «Основные средства», субсчет 11 «Bыбытие основных средств».

Списание расходов по раскорчевке деревьев: Дебет 91 «рочие доходы и расходы»»

Кредит 23 «Вспомогательное производство».

Следует отметить, что амортизация многолетних насаждений начисляется только после принятия их в эксплуатацию. Срок амортизации различен по каждому типу многолетних насаждений. Исходя из специфического характера деятельности санаториев и организаций гостиничного бизнеса, которая заключается в предоставлении услуг размещения, отдыха и оздоровления граждан, многолетние растения представляют собой декоративные озеленительные насаждения, облагораживающие территорию создающие условия для комфортного отдыха. Данный тип насаждений, в соответствии с Постановлением Правительства РФ «О Классификации основных средств, включаемых в амортизационные групाы», включен в последнюю десятую амортизационную группу (срок использования свыше 30 лет).
Одним из важнейших вопросов при учете затрат на благоустройство выступает их участие в исчислении налога на прибыль. Существуют разногласия по поводу того, в каких случаях разрешено включать затраты на благоустройство территории в расходы, уменьшающие налоговую базу при исчислении налога на прибыль. Исходя из специфики деятельности санаторных и гостиничных организаций, затраты на благоустройство для организаций гостиничного бизнеса и санаторно-курортных организаций относятся к затратам, оказывающими влияние на получение доходов и напрямую связанные с основной деятельностью организации. В этом случае, затраты на благоустройство включаются в исчисление налога на прибыль в качестве прочих расходов, связанных с производством и (или) реализацией.

Таким образом, знание специфики учета затрат по благоустройству в организациях санаторно-курортного типа и гостиничного бизнеса позволит грамотно вести бухгалтерский учет, рассчитывать налог на прибыль и составлять бухгалтерскую отчетность.

\section{ЛИТЕРАТУРА}

11. Налоговый кодекс Российской Федерации (часть вторая): Федеральный закон №117-Ф3 от 05.08.00 г. (в ред. от 05.04.16 г.) // СПС КонсультантПлюс. - Москва, 2016.

12. О классификации основных средств, включаемых в амортизационные группы: Постановление Правительства РФ №1 от 01.01.02 г. (в ред. от 09.12.08 г.) // СПС Консультант-Плюс. - Москва, 2016.

13. Положение по бухгалтерскому учету «Учет основных средств» (ПБУ 6/01): Приказ Минфина РФ от 30.03.01 г. №26н (в ред. от 06.04.15 г.) // СПС КонсультантПлюс. - Москва, 2016.

14. Методические рекомендации по бухгалтерскому учету основных средств сельскохозяйственных организаций: Приказ Минсельхоза РФ от 19.06.2002 г. №559// СПС КонсультантПлюс. - Москва, 2016.

15. Кузнецов, А.В. Актуальные вопросы идентификации основных средств / А.В. Кузнецов, Д.В. Луговской // Ресурсный потенциал национальной экономики в условиях глобализации: матер. Междунар. науч.-практ. конф. Краснодар: Кубанский гос. ун-т, 2008. Ч. 2. - С. 12-14. 
16. Луговской, Д.В. Проблемы учета капитальных вложений // В сборнике: Роль и місце бухгалтерского обліку, контролю и аналізу в розвитку економічноі науки i практики Збірник материалів II Міждународной науково-практичноі конференціі. Киів: Державний виший начальний заклад «Киівский национальний економичний університет имени Вадима Гетьмана», 2012. - С. 255-257.

17. Погосян, С.А. Особенности учета затрат на производство и выпуск продукции садоводства / С.А. Погосян, И.Н. Костюкова // В сборнике: Экономика: актуальные проблемы исследований на современном этапе. Материалы международной научно практической конференции. Краснодар: Краснодарский ЦНТИ, 2016. - С. 64-69.

18. Ордынская, М.Е. Управление затратами на предприятии: учеб. пособие // Адыгейский государственный университет. - Майкоп, 2016 - С. 67-69.

19. Шульга, А.А. Актуальные вопросы бухгалтерского учета в организациях сельского хозяйства / А.А. Шульга, И.Н. Костюкова // В сборнике: Экономика: актуальные проблемы исследований на современном этапе. Материалы международной научно-практической конференции. Краснодар: Краснодарский ЦНТИ, 2016. - С. 282-288. 

ИХ ВЛИЯНИЕ НА СИСТЕМУ БУХГАЛТЕРСКОГО УЧЕТА

Костюкова И.Н. к. э. н., доцент, Кубанский государственный университет, г. Краснодар Луговский Д.В. к. э. н., доцент, Кубанский государственный университет, г. Краснодар

\begin{abstract}
Аннотация. Основным предназначением предприятий общественного питания выступает производство продуктов питания. Изготовленная продукиия и покупные товары реализуются посредством их продажи потребителям (сфера торговли). Кроме того, предприятия общественного питания оказывают услуги, связанные с проведением досуга клиентов и другие дополнительные услуги.

Ключевые слова: общественное питание, бухгалтерский учет, технологический контроль, покупная стоимость, розничная (продажная) иена, калькулячиия, фактическая производственная себестоимость, нормативная себестоимость, издержки обращения.
\end{abstract}

\title{
PROPERTY ACCOUNTING IN HOTEL-RESTAURANT BUSINESS
}

Kostyukova I.N. cand. econ. sci., associate professor, Kuban state university, Krasnodar Lugovsky D.V. cand. econ. sci., associate professor, Kuban state university, Krasnodar

\begin{abstract}
The primary purpose of the catering is the food production. Manufactured products and purchased goods are sold through their sales to consumers (sales). In addition, public catering enterprises provide services related to the leisure activities of clients and other additional services. Key words: public catering, accounting, process control, purchase price, retail (sales) price, cost estimate, actual production cost, standard cost, distribution costs.
\end{abstract}

Общественное питание - одна из динамично развивающихся отраслей экономики. Оно включает в себя сферу производства, торговли и оказания услуг населению. Согласно ГОСТ 31985-2013 «Услуги общественного питания. Термины и определения» под общественным питанием понимается «самостоятельная отрасль экономики, состоящая из предприятий различных форм собственности и организационно-управленческой структуры, организующая питание населения, а также производство и реализацию готовой продукции и полуфабрикатов, как на предприятии общественного питания, так и вне его, с возможностью оказания широкого перечня услуг по организации досуга и других дополнительных услуг» [1].

В Общероссийском классификаторе видов экономической деятельности (ОКВЭД 2) общественное питание не выделено в качестве отдельной индустрии, а объединено в единый блок с гостиничной деятельностью (раздел I «Деятельность гостиниц и предприятий общественного питания»). Основным фактором, определяющим деятельность организаций общественного питания согласно ОКВЭД, служит факт предоставления продуктов питания и напитков, пригодных для непосредственного потребления на месте [2].

Согласно же Общероссийскому классификатору услуг населению (ОКУН) общественное питание представлено в одном блоке с услугами торговли и услугами рынков. Услуги общественного питания включают в себя:

- непосредственно услуги питания ресторана, кафе, столовой, закусочной, бара и предприятий других типов;

- услуги по изготовлению кулинарной продукции и кондитерских изделий; 
- услуги по организации потребления и обслуживания;

- услуги по реализации кулинарной продукции;

- услуги по организации досуга;

- информационно-консультативные услуги;

- прочие услуги общественного питания [3].

ГОСТ 30389-2013 «Услуги общественного питания. Предприятия общественного питания. Классификация и общие требования» определяет предприятие общественного питания как «имущественный комплекс, используемый юридическим лицом или индивидуальным предпринимателем для оказания услуг общественного питания, в т. ч. изготовления продукции общественного питания, создания условий для потребления и реализации продукции общественного питания и покупных товаров как на месте изготовления, так и вне его по заказам, а также для оказания разнообразных дополнительных услуг» [2].

Из вышесказанного следует, что основным предназначением предприятий общественного питания служит производство продуктов питания. Изготовленная продукция и покупные товары реализуются посредством их продажи потребителям (сфера торговли).

Под услугой индустрии питания понимается «результат деятельности предприятий общественного питания (юридических лищ или индивидуальных предпринимателей) по удовлетворению потребностей потребителя в продукции общественного питания, в создании условий для реализации и потребления продукции общественного питания и покупных товаров, в проведении досуга и в других дополнительных услугах» [1].

Предприятия общественного питания самостоятельно определяют перечень оказываемых населению услуг. К дополнитель ным услугам в сфере питания согласно ГОСТ 30389-2013 «Услуги общественного питания.
Предприятия общественного питания. Классификация и общие требования» «относят:

- услуги по организации и проведению кейтеринга, в т. ч. по доставке продукции по заказам потребителей и выездное обслуживание;

- организация музыкального и развлекательного (анимацио нного) обслуживания;

- банкетное обслуживание, в т. ч. специальных мероприятий;

- информацио нно-консультационные (консалтинговые) услуги;

- вызов такси по заказу (просьбе) потребителей;

- парковка или охраняемая стоянка автомобиля на территории предприятия (объекта)» [2].

Организации общественного питания классифицируются по характеру деятельности, типам и мобильности.

По характеру деятельности выделяют:

- производственные предприятия общественного питания, которые изготавливают продукты питания и организуют их доставку потребителям. К ним относятся заготовочные цехи (предприятия), специализированные кулинарные цехи, цехи (предприятия) по производству полуфабрикатов и кулинарных изделий; цехи (предприятия) бортового питания и др.;

- производственные предприятия общественного питания, осуществляющие продажу собственной продукции и покупных товаров и обслуживание потребителей с потреблением на месте и на вынос (вывоз) с возможностью доставки. К ним относятся рестораны, кафе, бары, предприятия быстрого обслуживания, столовые, закусочные, кафетерии и буфеты;

- торговые предприятия общественного питания, организующие продажу продуктов питания с возможным потреблением их на месте (магазины или отделы). 
По типам предприятия общественного питания классифицируются на рестораны, кафе, бары, предприятия быстрого обслуживания, столовые, буфеты, магазины кулинарии, кафетерии.

По мобильности предприятия общественного питания подразделяют на стационарные и передвижные.

В зависимости от организации процесса производства продукции выделяют предприя тия, работающие на сырье, полуфабрикатах или комбинированные.

По уровню обслуживания предприятия общественного питания классифицируются на классы (категории): люкс, высший, первый.

В зависимости от месторасположения выделяют общедоступные предприятия общественного питания и закрытого типа, в которых обслуживают строго определенный контингент потребителей.

По времени функционирования выделяют постоянно действующие предприятия и сезонные (летние).

Организации общественного питания могут располагаться в жилых и общественных зданиях, зданиях гостиниц, вокзалов, торговоразвлекательных и культурно-развлекательных центров, на спортивных объектах, в научных, образовательных и медицинских организациях, в офисах компаний; на территории различных промышленных объектов, санаторно-курортных, оздоровительных учреждений, воинских частей, исправительных учреждений; на транспорте.

Одной из основных особенностей предприятий общественного питания является обеспечение безопасности жизни и здоровья потребителей. Это связано с тем, что продукты питания имеют ограниченный срок хранения и продажи. В процессе изготовления продукции в организациях осуществляется технологический контроль качества сырья, материалов, пищевых продуктов, готовой продукции, полуфабрикатов и технологических процессов. Технологический контроль включает в себя три вида контроля: входной, операционный и приемочный контроль.

Входной контроль осуществляется на стадии приемки сырья, материалов, пищевых продуктов и полуфабрикатов и заключается в контроле показателей их качества и безопасности.

Операционный контроль - это контроль параметров и показателей в ходе или после окончания технологической операции.

По итогам приемочного контроля показателей качества и безопасности изготовленной продукции принимается решение о ее пригодности к реализации.

Помещения организаций общественного питания обставлены мебелью (барными и буфетными стойками, столами, стульями, креслами, диванами), в наличии имеются предметы декора, столовая посуда и приборы, столовое белье.

Описанная специфика деятельности индустрии общественного питания оказывает влияние на построение системы бухгалтерского учета в организациях данной отрасли экономики.

На предприятиях общественного питания, изготавливающих собственную продукцию, учет сырья, готовых изделий и полуфабрикатов осуществляется аналогично их учету в организациях пищевых производств.

Стоимость сырья и товаров формируется непосредственно на счетах 10 «Материалы» и 41 «Товары» с использованием или без использования дополнительных счетов 15 «Заготовление и приобретение материальных ценностей» и 16 «Отклонение в стоимости материальных ценностей».

Учет сырья на счете 10 «Материалы», как правило, осуществляют производственные 
предприятия общественного питания, которые изготавливают продукты питания (полуфабрикаты, кулинарные изделия и т. д.) в большом количестве для последующей их продажи через торговую сеть. Другие же предприятия общественного питания, в большинстве случаев, учитывают сырье вместе с товарами на счете 41 «Товары».

В соответствии с ПБУ 5/01 «Учет материально-производственных запасов» товары могут учитываться одним из следующих способов:

1) по покупной стоимости непосредственно на счете 41 «Товары»;

2) по розничным (продажным) ценам с обособленным учетом наценок (скидок) на счете 42 «Торговая наценка» [4].

Предприятия общественного питания осуществляют торговлю изготовленной ими продукцией и товарами не только через рестораны, столовые, кафе, но и через бары, буфеты и магазины. При этом приобретенные сырье и товары первоначально приходуют на склад (кладовую) предприятия по покупной стоимости или по продажным ценам с добавлением величины торговой наценки. Затем со склада сырье и товары отпускаются в соответствующие подразделения предприятия в качестве сырья и товаров (рестораны, столовые, кафе) или в качестве товаров (бары, буфеты, магазины). Следует отметить, что кулинарные изделия, приготовленные ресторанами, столовыми, кафе, также отпускаются ими на продажу в бары, буфеты и магазины.

Согласно ПБУ 5/01 Учет материально-производственных запасов» при отпуске сырья и товаров (кроме сырья и товаров, которые учитываются по продажной стоимости) «в производство и ином выбытии их оценка производится одним из следующих способов:

- по себестоимости каждой единицы;

- по средней себестоимости;
- по себестоимости первых по времени приобретения материально-производственных запасов (способ ФИФО)» [4].

Все расходы на изготовление изделий общественного питания собираются на счете 20 «Основное производство»:

Дебет 20 «Основное производство»

Кредит 02 «Амортизация основных средств», 10 «Материалы», 70 «Расчеты с персоналом по оплате труда», 69 «Расчеты по социальному страхованию и обеспечению».

Следует отметить, что в аналитическом и синтетическом учете остатки готовой продукции на начало (конец) отчетного периода в местах их хранения (на складе или кухне) подлежат оценке по фактической производственно й себестоимости или по нормативной себестоимости.

Последний вариант оценки готовой продукции (по нормативной себестоимости), как правило, применяется на предприятиях общественного питания с массовым и серийным характером производства, которые производят большую номенклатуру изделий.

Разница между фактической и нормативно й себестоимостью (учетной ценой) изделий отражается в учете одним из двух способов - на счете 40 «Выпуск продукции (работ, услуг)» или на отдельном субсчете «Отклонения фактической себестоимости готовой продукции от учетной стоимости», открытом в дополнение к счету 43 «Готовая продукция». Одновременно со списанием готовых изделий общественного питания (при их продаже, отпуске и т. д.) отклонения между фактической и нормативной себестоимостью, приходящиеся на проданную продукцию, списываются на счета учета продаж.

Вариант оценки, когда в качестве учетной цены изделий выступает фактическая производственная себестоимость, используется предприятиями общественного питания, как 
правило, при производстве массовой продукции незначительной номенклатуры или при единичном и мелкосерийном выпуске продукции.

Одной из особенностей индустрии питания является то, что в основе установления себестоимости изделий общественного питания лежит калькуляция продукции. Калькуляция составляется на 100 порций в случае, если нормы закладки в рецептуре приведены на одну порцию или в расчете на 10 кг в случае, если нормы закладки в рецептуре установлены на 1 кг.

На каждое изготовленное блюдо составляется калькуляционная карточка, данные которой служат основанием для формирования продажной цены продукции. Если предприя тие учитывает сырье по покупной стоимости, то в калькуляционной карточке торговая наценка показывается отдельной строкой. При применении же предприятием в качестве учетных цен - продажных, торговая наценка уже включена в стоимость сырья. Следует отметить, что продажная цена кулинарной продукции формируется с учетом налога на добавленную стоимость, если предприятие выступает плательщиком НДС.

В случае если предприятие общественного питания согласно принятой учетной политике использует для учета сырья и товаров только счет 41 «Товары», то к нему открываются следующие субсчета:

- 41-1 «Сырье и товары на складе (кладовой)»;

- 41-2 «Товары и продукция собственного производства»;

- 41-3 «Тара под товаром и порожняя».

В индустрии общественного питания в отличие от других отраслей экономики, счет 20 «Основное производство» выступает материальным, а не калькуляционным счетом. На нем ведется учет наличия и движения товарно-материальных ценностей, отпущенных на кухню (в производство). Все остальные издержки обращения, связанные с производством и продажей продукции собственного производства и товаров, собираются на счете 44 «Расходы на продажу».

На предприятиях общественного питания номенклатура статей издержек обращения и производства идентична номенклатуре, присущей торговым предприятиям:

- транспортные расходы;

- расходы на оплату труда;

- отчисления на социальные нужды;

- расходы на аренду и содержание зданий, сооружений, помещений, оборудования и инвентаря;

- амортизация основных средств;

- расходы на ремонт основных средств;

- списание стоимости санитарной и специальной одежды, столового белья, посуды, приборов, других малоценных предметов;

- расходы на топливо, газ, электроэнергию для производственных нужд;

- расходы на хранение, подработку, подсортировку и упаковку продукции и товаров;

- расходы на рекламу;

- потери товаров и технологические отходы;

- расходы на тару;

- прочие расходы.

В конще отчетного периода (месяца) издержки обращения в полном объеме списываются в дебет субсчета 90-2 «Себестоимость продаж». Следует отметить, что согласно Методическим указаниям по учету материально производственных запасов транспортно-заготовительные расходы могут, в случае если их величина составляет значительный удельный вес в общем объеме выручки от продаж кулинарных изделий и товаров (более 10\%), пропорционально распределяться между покупной стоимостью проданных в данном месяце кулинарных изделий и товаров и их остатком на конец отчетного месяца [4]. Транспортно заготовительные расходы, приходящиеся на 
остаток не проданных на конец месяца кулинарных изделий и товаров, учитываются на счете 44 «Расходы на продажу» и переходят на следующий месяц.

Таким образом, действующим российским законодательством допускается наличие остатка по счету 20 «Незавершенное производство (44 «Расходы на продажу») в отношении транспортно-заготовительных расходов, приходящихся на остаток кулинарных изделий и товаров.
Оказание услуг конечным потребителям (клиентам) за наличный расчет предприя тиями общественного питания осуществляется с применением контрольно-кассовой техники в соответствии с Федеральным законом «О применении контрольно-кассовой техники при осуществлении наличных денежных расчетов и (или) расчетов с использованием платежных карт» [5].

\section{ЛИТЕРАТУРА}

1. ГОСТ 31985-2013. Межгосударственный стандарт. Услуги общественного питания . Термины и определения: Приказ Росстандарта от 27.06.13 г. №191 -ст. // СПС «КонсультантПлюс». - Москва, 2016.

2. ГОСТ 30389-2013. Межгосударственный стандарт. Услуги общественного питания. Предприятия общественного питания. Классификация и общие тре бования: Приказ Росстандарта от 22.11.13 г. №1676-ст. // СПС «КонсультантПлюс». - Москва, 2016.

3. Положение по бухгалтерскому учету «Учет материально-производственных запасов» (ПБУ 5/01): Приказ Минфина РФ от 09.06.01 г. №44н (в ред. от 16.05.16 г.) // СПС «Консультант Плюс». - Москва, 2016.

4. Методические указания по бухгалтерскому учету материально-производственных запасов: Приказ Минфина РФ от 28.12.01 г. №119н (в ред. от 24.12.10 г.) // СПС «КонсультантПлюс». - Москва, 2016.

5. О применении контрольно-кассовой техники при осуществлении наличных денежных расчетов и (или) расчетов с использованием платежных карт: Федеральный закон от 22.05.03 г. №54-Ф3 (в ред. от 03.07.16 г.) // СПС «КонсультантПлюс». Москва, 2016.

6. Мазлова, Л.И. Обеспечение материальной заинтересованности рабочих в результатах труда / Л.И. Мазлова, И.Н. Костюкова // Известия высших учебных заведений. Пищевая технология, 1991. №1-3. - С. 15-17.

7. Патров, В.В. Бухгалтерский учет в торговле и общественном питании - Санкт-Петербург: Питер; Москва: Издательский дом БИНФА, 2009. - 224 с. 


\title{
ПОНЯТИЕ, КЛАССИФИКАЦИЯ И УЧЕТ СПЕЦИАЛЬНОЙ ОСНАСТКИ И СПЕЦИАЛЬНОЙ ОДЕЖДЫ
}

Костюкова И.Н.

к. э. н., доцент, Кубанский государственньй университет, г. Краснодар Луговский Д.В.

к. э. н., доиент, Кубанский государственныий университет, г. Краснодар

Txazanco P.A.

к. э. н., доиент, Кубанский государственный университет, г. Краснодар

\begin{abstract}
Аннотация. Российское бухгалтерское законодательство в настоящее время сохранило в своем роде уникальную группу объектов, занимающих промежуточное положение между основными средствами и материально-производственными запасами - это, так называемое специиальное имущество. В статье дана классификация и рассмотрены основнье элементы специального имущества. Проанализированы особенности документального оформления, аналитического и синтетического учета спещииальной одежды и спещиальной оснастки. Раскрыта учетная политика, применяемая организацией в отнотении специального имущества.

Ключевые слова: специальное имущество, специальная одежда, специальная обувь специальная оснастка, специальный инструмент, специальные приспособления, специальное оборудование, учет специильной одежды, учет специальной оснастки.
\end{abstract}

\section{CONCEPTION, CLASSIFICATION AND ACCOUNTING OF SPECIAL EQUIPMENT AND SPECIAL CLOTHES}

Kostyukova I.N. cand. econ. sci., associate professor, Kuban state university, Krasnodar Lugovsky D.V. cand. econ. sci., associate professor, Kuban state university, Krasnodar Tkhagapso R.A. cand. econ. sci., associate professor, Kuban state university, Krasnodar

\begin{abstract}
Russian accounting legislation currently preserved a unique group of objects occupies an intermediate position between the basic means and material-industrial stocks is the so - called special assets. The article provides a classification and describes the main elements of the special property. Analyzed documentation, analytical and synthetic accounting of special clothes and special equipment. Disclosed the accounting policy applied by the organization in respect of special assets.

Keywords: special equipment, special clothing, special shoes, special equipment, special tool, special adaptations, special equipment, special clothing, special equipment.
\end{abstract}

Российское бухгалтерское законодательство в настоящее время сохранило в своем роде уникальную группу объектов, занимающих промежуточное положение между основными средствами и материально-производственными запасами - это, так называемое специальное имущество. С экономической точки зрения его следовало бы отнести к основным средствам, поскольку, по сути, такое имущество используется в качестве средств труда, т. е. вследствие их воздействия на предмет труда (сырье и материалы) создается готовая продукция. Однако, вследствие сознательно введенных юридических положений такое имущество в ряде случаев может учитываться в составе материально-про изводственных запасов. Причиной тому в случае со специаль но й одеждой, вероятно, послужил принцип существенности (ее стоимость невелика в сравне- 
нии со зданиями, сооружениями, оборудованием и многими другими объектами основных средств), а в случае со специаль но й оснасткой - их уникальность и обусловленное таковой однократное использование в процессе изготовления продукции (выполнения работ, оказания услуг).

Рассмотрим более подробно элементы, входящие в состав специального имущества (рисунок 1).

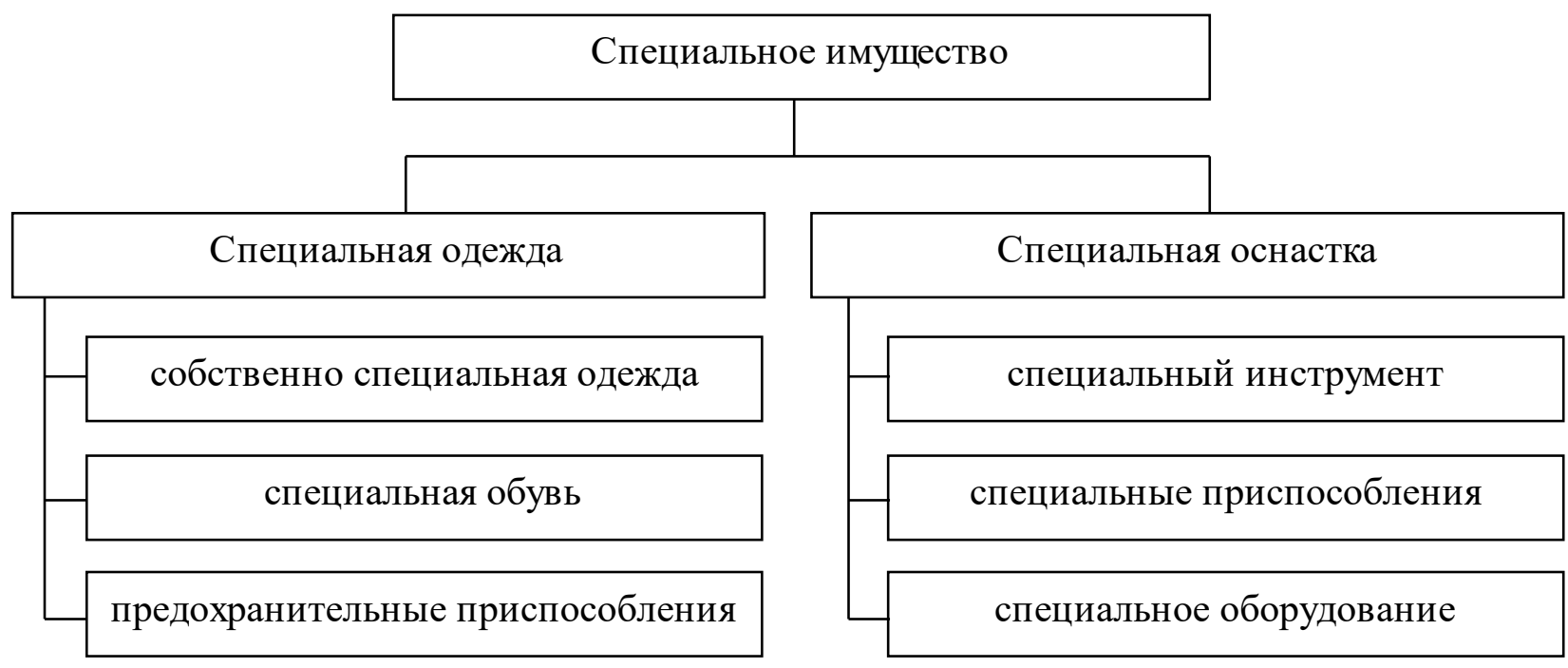

Рисунок 1 - Состав и структура специального имущесетва

\section{Специальное имуцество (специальная} одежда и специальная оснастка) - часть производственного инвентаря и хозяйственных принадлежностей, предметь, обладающие индивидуальными (уникальными) свойствами и предназначенные для выполнения определенных видов работ определенными лицами.

Специальная одежда - это средства индивидуальной защчиты работников при выполнении определенных видов работ (например, различных видов строительных, торговых, сельскохозяйственных и иных работ). Собирательное понятие «специальная одежда» объединяет в себе собственно специиальную одежду, специальную обувь и предохранительные приспособления (комбинезоны, костюмы, куртки, брюки, халаты, полушубки, тулупы, сапоги, ботинки, рукавицы, очки, шлемы, респираторы и др.).

Особенность спецостасткии и отличие ее от других видов производственного и хозяй- ственного инвентаря, как уже подчеркивалось, заключается в ее индивидуальности (уникаль ности).

Специальная оснастка - технические средства, обладающие уникальными свойствами u предназначенные для производства конкретных видов продукиии (работ, услуг) или выполнения нестандартных операиий. Специальная оснастка включает в себя специальный инструмент, специальные приспособления и специальное оборудование.

Специиальный инструмент и специиальные приспособления - это технические средства, обладаюшие индивидуальными (уникальными) свойствами и предназначенные для обеспечения условий изготовления (выпуска) конкретных видов продукции (выполнения работ, оказания услуг). Например, штампы, прессформы, изложницы, прокатные валки, модельная оснастка, стапели, кокили, опоки, шаблоны и др. 
Специальное оборудование - это многократно используемые в производстве средства труда, которые обеспечивают условия для выполнения специифических (нестандартных) технологических операций. К специальному оборудованию, в частности, «относится :

а) специальное технологическое оборудование (химическое, металлообрабатывающее, кузнечно-прессовое, термическое, сварочное и др.), применяемое для выполнения нестандартных операций;

б) контрольно-испытательные аппаратура и оборудование (стенды, пульты, макеты готовых изделий, испытательные установки), предназначенные для регулировок, испытаний конкретных изделий и сдачи их заказчику (покупателю);

в) реакторное оборудование и др.» [1].

Не признается спецоснастной (специструментом, спецприспособлениями и спецоборудованием) предметы, используемые для выполнения типовых операций или для выпуска типовых видов продукции (работ, услуг).

Организация, исходя из особенностей технологического процесса, самостоятельно устанавливает конкретный перечень специаль но й оснастки и специальной одежды.

Учет спецоснастки и спецодежды ведется по правилам, установленным для учета материалов с учетом представленных ниже особенностей.

Организация вправе вести учет специального имущества в порядке, предусмотренном для учета основных средств. Таким образом, специмущество в зависимости от принятой учетной политики может быть учтено:

а) в составе материалов;

б) в составе основных средств.

Источники поступления в организацию специальной оснастки и специальной одежды ничем не отличаются от источников поступления иных запасов: это приобретение за плату, безвозмездное получение, изготовление собственными силами и др.

Принятая к бухгалтерскому учету специальная оснастка и специальная одежда отражается на отдельном субсчете 10-10 «Специальная оснастка и специальная одежда на складе» счета 10 «Материалы» (или на соответствующих субсчетах счета 01 «Основные средства», если это предусмотрено учетной политикой):

Дебет 10 «Материаль», субсчет «Специальная оснастка и специальная одежда на складе»

Кредит 20 «Основное производство», 23 «Вспомогательные производства», 60 «Расчетьл с поставщиками и подрядчиками» идр. - на сумму фактических затрат, связанных с приобретением и (или) изготовлением специального имущества.

На поступившую на склад специальную оснастку и специальную одежду выписывается приходныци ордер (форма №M-4).

При производстве специальной оснастки и специальной одежды собственными силами «затраты по ее изготовлению формируются на соответствующих счетах учета затрат на производство (20 «Основное производство», 23 «Вспомогательные производства», и др.). Окончание работ по изготовлению специального имущества подтверждается актом выполненных работ по изготовлению специильной оснастки и специиальной одеждыл» [1].

Сдача подразделениями-изготовителям и специальной оснастки и специальной одежды на склад оформляется требованием-накладной (форма М-11) или накладной на отпуск материалов на сторону (форма №M-15), которые выписываются, как правило, в трех экземплярах. Первый экземпляр служит основанием для оприходования изготовленного специального имущества и списания затрат по соответствующему заказу, второй экземпляр 
передается вместе с произведенными ценностями на склад, а третий экземпляр остается в подразделении- изготовителе.

«Фактическая себестоимость специального имущества, изготовленного собственными силами, рассчитывается в порядке, который установлен для исчисления себестоимости соответствующих видов продукции» [1].

Отпуск специальной оснастки и специальной одежды в производство (эксплуатацию) со склада осуществляется на основании лимитно-заборных карт (форма №M-8), требований-накладных (форма М-11), накладных на отпуск материалов на сторону (форма №M$15)$ :

Дебет 10 «Материаль», субсчет «Специиальная оснастка и спецчиальная одежда в эксплуатацุии»

Кредит 10 «Материаль», субсчет «Специиальная оснастка и специиальная одежда на складе».

«Ведение аналитического учета специального имущества, находящегося в производстве (эксплуатации), осуществляется в разрезе наименований (номенклатурных номеров), количества и фактической себестоимости с указанием даты поступления в производство, мест эксплуатации и материально ответственных лищ) [1].

«Стоимость специиальной оснастки, переданной в эксплуатациию, может списываться:

а) пропоричионально объему выпущзенной продукиии (работ, услуг). Сумма погашения стоимости спецоснастки определяется исходя из объема продукции (работ, услуг) в натуральном измерении за отчетный период и соотношения фактической себестоимости спецоснастки к предполагаемому объему выпуска продукции (работ, услуг) за весь ожидаемый срок ее полезного использования. Применение данного способа целесообразно для тех видов спецоснастки, срок полезного использования которой непосредственно связан c объемом произведенной продукции (штампы, пресс-формы, прокатные валки и т. П.);

б) линейнылм способом. Сумма погашения стоимости спецоснастки определяется исходя из ее фактической себестоимости и норм, исчисленных исходя из сроков ее полезного использования. Применение способа рекомендовано для тех видов спецоснастки, физический износ которой непосредственно не связан с объемом выпущенной продукции (стапельная оснастка, шаблоны, контрольно-испытательная аппаратура и т. п.);

в) путем полного погашения стоимости в момент передачи в производство (эксплуатацุию). Допускается только для спецоснастки, предназначе нной для индивидуальных заказов или используемой в массовом производстве» $[1]$.

«Для обеспечения дополнительного контроля за сохранностью специальной оснастки, переданной в эксплуатацию, ее учет может быть организован на внесистемном (забалансовом) счете «Специальная оснастка, переданная в эксплуатацию» в разрезе наименований (номенклатурных номеров) спецоснастки или еe групп (укрупненных комплектов) по фактической себестоимости приобретения (изготовления). Использование забалансового учета целесообразно в случае полного переноса (списания) ее стоимости и (или) наличия обязательств по хранению спецоснастки после окончания ее эксплуатации (обязательства по гарантийному ремонту и обслуживанию, мобилизацио нный запас и т. п.)» [1].

Заметим, однако, что существует и более простое решение, при котором со счета 10 «Материалы» списывается только стоимость актива, количество же остается неизменным. 
В результате в синтетическом учете продолжают числиться объекты, стоимость которых погашена, но сами объекты еще не списаны с учета, что соответствует реальному положению вещей.

Аналогичная ситуация возникает и в учете амортизируемых активов, погашение стоимости которых вовсе не означает их списания с учета и не снижает и, тем более не аннулируе т ответственность материально ответственного лица.

Напомним, что выбытие любого материального актива оформляется соответствующим документом (накладной, актом о списании и т. п.).

Списание специальной оснастки и специальной одежды с бухгалтерского учета осуществляется только при фактическом физическом выбытии. При этом окончание переноса стоимости объекта учета на себестоимость выпущенной продукции (работ, услуг) может не совпадать по времени с его фактическим физическим выбытием [1].

Стоимость специальной одежды, переданной в эксплуатацию, может погашаться:

а) линейным способом, исходя из сроков полезного использования спецодежды, предусмотренных в типовых отраслевых нормах бесплатной выдачи специальной одежды, специальной обуви и других средств индивидуальной защиты, а также в Правилах обеспечения работников специальной одеждой, специальной обувью и другими средствами индивидуальной защиты;

б) путем единовременного списания стоимости в момент выдачи работникам. Допускается только для спецодежды, срок эксплуатации (носки) которой согласно нормам выдачи не превышает 12 месяцев.

Погашение стоимости специально й оснастки и специальной одежды в бухгалтерском учете отражается:
Дебет 20 «Основное производство», 23 «Вспомогательные производства» и др.

Кредит 10 «Материаль»", субсчет «Специ альная оснастка и специальная одежда в эксплуатациии».

Затраты на ремонт и обслуживание специального имущества (например, заточка специального инструмента, замена отдельных узлов и деталей и т. п.) подлежат включению себестоимость производимой продукции, работ, услуг:

Дебет 20 «Основное производство» и др.

Кредит 23 «Вспомогательные производства», 60 «Материаль»», 70 «Расчеты с персоналом по оплате труда» и др.

При невозможности продажи или иного использования специальной оснастки вследствие прекращения выпуска продукции, работ, услуг, ее стоимость списывается на прочие расходы:

Дебет 91 «Прочие доходы и расходы»

Кредит 10 «Материаль», субсчет «Специальная оснастка и специиальная одежда в эксплуатациич.

Материальные ценности, полученные от разборки специальных активов и пригодные для дальнейшего использования, сдают на склад на основании накладных:

\section{Дебет 10 «Материаль»»}

Кредит 91 «Прочие доходы и расходыл» - в оценке, установленной комиссией.

Списание специальной оснастки и специальной одежды со счетов системеного и внесистемного учета производится на основании актов на списание. В них, в частности указывается: наименование списываемых объектов и их отличительные признаки, количество; фактическая себестоимость; сумма перенесенной стоимости к моменту списания; установленный срок эксплуатации (объем работ); дата ввода в эксплуатацию; причина выхода из строя; предложения о списании объекта и о 
взыскании материального ущерба с виновных лиц.

Допускается осуществлять учет наличия и движения специальной оснастки в целом по ее укрупненным комплектам, объединенным (сгруппированным) по видам производимой продукции (работ, услуг).

Отпуск специальных инструментов и специальных приспособлений со склада производится в соответствии с установленными организацией лимитами (нормами) отпуска. Контроль за их выдачей ведется на складе в специальных карточках, которые открываются на каждое подразделение.

Методическими указаниями по бухгалтерскому учету специального инструмента, специальных приспособлений, специального оборудования и специальной одежды предусмотрено «два варианта оперативного (количественного) учета выдачи в производство (эксплуатацию) и возврата на склад специиальных инструментов и спецциальных приспособлений» [1].

«При первом варианте поступление в кладовую и возврат на склад оформляется требованиями, лимитными картами или накладными.

Второй вариант предусматривает выписку требований или лимитных карт лишь при первоначальном отпуске со склада специальных инструментов и специальных приспособлений. Обмен на складе негодных, изношенных инструментов и приспособлений на годные штука за штуку производится без оформления первичных документов на выдачу. Обмен оформляется актами выбытия (списания) по причине нормального износа специальных инструментов и специальных приспособлений» [1].

Если специнструменты и спецприс пособления на срок более месяца, то их отпуск производится в соответствии с технологическими картами. На основании требования мастера производится первоначальная выдача специального инструмента и производится запись в лицевой карточке. Она открывается в одном экземпляре на каждое рабочее место получателя инструмента (наладчика, рабочего). Работник обязан расписаться за полученный инструмент в лицевой карточке.

Последующая выдача из кладовой годного инструмента взамен нормально изношенного штука за штуку первичными учетными документами не оформляется либо оформляется записями в лицевой карточке. Кладовщик расписывается в получении негодных инструментов, а рабочий расписывается в получении годных инструментов с указанием даты. Выдача годного специнструмента в обмен на негодный инструмент производится на основании акта выбытия (списания) по причине нормального износа (нормальной эксплуатаuุuu).

«При выдаче годных инструментов без сдачи негодных или в обмен на инструменты, пришедшие в негодное состояние досрочно, выписывается требование и производится запись в лицевой карточке работника» [1].

«Если специальные инструменты выдаются на срок не более месяца (на смену или иной период), то может применяться марочная система регистрации выдачи, которая не предполагает использование каких-либо документов. Выдача инструментов осуществляется на основании инструментальных марок. На них указывается номер подразделения, номер кладовой, а также табельный номер работника или порядковый номер марки и номенклатурный номер инструмента. Инструменталь ные марки выдаются кладовой на основании требования, подписанного мастером, работнику под расписку в специальной книге (лицевых карточках). На каждую инструменталь ную марку выдается только один предмет» [1]. 
Организации могут применять одномарочную или двухмарочную систему выдачи специальных инструментов работникам в кратковременное пользование.

«Если в организации применяется одномарочная система, то при получении инструментов, кладовщик помещает инструментальные марки в ячейки стеллажа, в которых нахо дились выданные инструменты. Затем при их сдаче в кладовую, работнику возвращаются обратно инструментальные марки.

При двухмарочной системе используется два вида марок: марки с табельным номером рабочего имарки с номенклатурным номером инструмента. При получении инструмента работник сдает в кладовую инструментальные марки со своим табельным номером, а инструментальные марки с номенклатурным номером инструмента, хранящиеся до выдачи инструмента в соответствующей ячейке стеллажа, перемещаются на соответствующее контрольное устройство» [1].

Вместе с инструментальными номенклатурными марками могут применяться и специальные инструментальные жетоны, предназначенные для контроля за запасами специальных инструментов или определения времени выдачи (смены) инструмента.

Сдачу специнструмента на проверку, заточку или ремонт кладовая оформляет квитанцией (заказом) в двух экземплярах. Первый экземпляр квитанции (заказа) передается в лабораторию (ремонтную мастерскую) вместе с инструментом под расписку на втором экземпляре. Второй экземпляр квитанции (заказа) остается в кладовой и служит основанием для получения проверенного или отремонтированного инструмента из лаборатории.

«В случае поломки, порчи и утери специальных инструментов и специальных приспособлений оформляется акт выбытия (списания), в котором указываются причины выбытия» [1].
«Выдача специальной одежды работникам производится в порядке, установленном коллективным договором на основе типовых отраслевых норм бесплатной выдачи специальной одежды, специальной обуви и других средств индивидуальной защиты, а также правил обеспечения работников специальной одеждой, специальной обувью и другими средствами индивидуальной защиты» [1].

При отпуске работнику специальной одежды выписывается требование или иной первичный документ, в котором указывают основание выдачи одежды.

На каждого работника заводится личная карточка работника, в которой отражаются выдача и возврат специальной одежды. При этом в личной карточке указываются наименование выданной спецодежды, ее стоимость, срок носки, процент годности на момент выдачи и др.

«Спецодежда, выданная работникам и находящаяся в собственности организации, подлежит возврату при увольнении или при переводе на другую работу, для которой специальная одежда не предусмотрена, а также по окончании сроков ее носки взамен получаемой новой» [1].

Дежурная специальная одежда коллективного пользования выдается из кладовой подразделения работникам только на время выполнения определенных работ или закрепляется за определенными рабочими местами (например, тулупы на наружных постах, перчатки диэлектрические при электроустановках и т. д.) и передается от одной смены другой. В этих случаях спецодежда выдается под ответственность материально ответственному лицу с записью в отдельной карточке, в которой делается пометка «дежурная».

«На сданную работниками специальную одежды в стирку, дезинфекцию, ремонт, а также зимнюю (теплую) одежду с наступле- 
нием летнего (теплого) времени для организованного хранения делаются записи в ведомости о приемке специальной одежды, которая подписывается материально ответственным лицом. Возврат работникам спецодежды отражается в этой же ведомостям под расписку работника» [1].

\section{ЛИТЕРАТУРА}

1.Методические указания по бухгалтерскому учету специального инструмента, специальных приспособлений, специального оборудования и специальной одежды: Приказ Минфина РФ от 26.12.02 г. №135н (в ред. от 24.12.10 г.) // СПС «КонсультантПлюс». - Москва, 2016. 


\section{ЗНАЧЕНИЕ И ПЕРВЫЕ РЕЗУЛЬТАТЫ ВНЕДРЕНИЯ ПИЛОТНОГО ПРОЕКТА «ПРЯМЫЕ ВЫПЛАТЫ»}

Лафишева А.А., Нехай 3.А. студентки, Адьгейского государственного университета, г. Майкоп Научный руководитель: Силина Т.А. к.э.н., доцент, Адыгейский государственныий университет, г. Майкоп

Аннотация: В статье рассмотрено изменение системы уплаты страховых взносов, список субъектов, в которых действует пилотный проект ФСС «Прямые выплаты», его сущзность, положительные стороны, принципы постепенного внедрения и главная цุель перехода к нему.

Ключевые слова: пилотный проект, прямые выплаты, ФСС, зачетная схема.

SIGNIFICANCE AND FIRST RESULTS OF THE IMPLEMENTATION OF THE PILOT PROJECT "DIRECT PAYMENTS"

Lafisheva A.A Nekhay Z.A student, Adyghe State University, Maikop Research supervisor: Silina T.A. Cand.Econ.Sci., associate professor, Adyge state university, Maykop

Abstract: The paper considers the change of the system of payment of insurance premiums, the list of subjects where there is a pilot project, the positive side proeta, the main purpose of the transition to it, and the gradual introduction of the essence of the pilot project "Direct payments" Keywords: pilot, direct payments, FSS, the test circuit.

Система социального страхования в России зародилась более ста лет назад еще в царские времена. С тех пор было осуществлено много различных преобразований, вызванных как политическими, так и социальными предпосылками разных периодов истории государства. Тем не менее, современная система, постоянно совершенствуясь, имеет своей целью социальную защиту наемных работников.

Последнее преобразование системы было начато с 01.07.2011. Проект «Прямые выплаты» был запущен в 2011 году в Нижегородской области и Карачаево-Черкесской республике. Этот пилотный проект предусматривает переход на выплату пособий застрахованным гражданам напрямую из Фонда социального страхования взамен действующей «зачетной схемы». До старта пилотного проекта во всех регионах Российской Федерации пособия застрахованным лицам выплачивались работодателем и сокращали при этом сумму страховых взносов.

Согласно пилотному проекту ФСС, новый подход, утвержденный постановлением Правительства РФ от 21.04.2011 № 294, состоит в том, что при наступлении страхового случая работник обращается к работодателю с заявлением и установленными законом документами, а работодатель передает эти документы в ФСС в течение 5 календарных дней. После этого Фонд принимает решение и выплачивает денежные средства застрахованному работнику переводом либо на личный банковский счет в течение 10 календарных дней. Первые 3 дня болезни всё так же оплачивает работодатель за счет средств организации, а последующие дни - уже Фонд из своего бюджета. 
Для тестирования пилотного проекта ФСС было выбрано несколько субъектов. Данный список пополнился в 2016 году:

- Карачаево-Черкесская Республика и Нижегородская область (с 01.01 .2012 по 31.12.2016);

- Астраханская, Курганская, Новгородская, Новосибирская, Тамбовская области и Хабаровский край (с 01.07.2012 по 31.12.2016);

- Республика Крым, Севастополь (с 01.01.2015 по 31.12.2016);

- Республика Татарстан, Белгородская, Ростовская и Самарская области (с 01.07.2015 по 31.12.2016);

- Республика Мордовия, Брянская, Калининградская, Калужская, Липецкая и Ульяновская области (с 01.07.2016 по 31.12.2016).

Карачаево-Черкесия вошла в число 13 регионов Российской Федерации, где будет реализовываться пилотный проект по выписке электронных больничных. Результатом внедрения проекта является то, что медицинские учреждения формируют электронные документы и сразу же отправляют их через интернет в ФСС РФ. Тем самым на руки работнику лист нетрудоспособности больше не выдается. Это нововведение полностью решило проблему поддельных больничных и ошибок в них. Проект значительно облегчил работу с документооборотом.

Принимать участие в пилотном проекте ФСС все работодатели указанных регионов должны обязательно, закон не предусматривает право выбора.

При переходе от «зачетного механизма» к «прямым выплатам» меняется взаимодействие между отделениями Фонда, работодателями и застрахованными гражданами.

Как отмечает О.И. Батракова, у бухгалтера работы пока не уменьшится, но в дальнейшем все будет делать ФСС России. После реализации пилотного проекта бухгалтерам больше не нужно будет обращаться в отделение ФСС
России за выделением средств на обеспечение пособий - понадобится лишь направить реестр в электронном виде, что значительно проще.

В регионах, где реализуется пилотный проект «Прямые выплаты», граждане гарантировано получают пособия, предусмотренные государством, даже в случае работы на предприятиях, находящихся в различных стадиях банкротства. Также решается проблема обеспечения пособиями граждан, работодатель которых имеет финансовые проблемы или фактически прекратил свою деятельность. Это касается и работников организаций, местонахождение которых установить невозможно.

Главной целью перехода на прямые выплаты для ФСС стало эффективное расходование средств бюджета. Принятые новшества дают возможность фонду отслеживать правомерность начисления пособия и корректность его расчета до того, как выплата произведена. Это является действенным инструментом при борьбе с мошенниками, которые подделывают листки нетрудоспособности. Кроме того, проект «Прямые выплаты» позволит ФСС оптимизировать расходы за счет устранения нецелевых выплат, оказывающих влияние на сбалансированность бюджета.

В будущем бухгалтерии страхователей будут освобождены от этих обязанностей, а необходимые для расчетов сведения фонд будет получать из персонифицированного учета ПФР.

Застрахованные граждане Российской Федерации вправе ждать от пилотного проекта ФСС защиту от недобросовестных работодателей, которые задерживают или вовсе не выплачивают пособия, так как оплата осуществляется непосредственно территориальным органом фонда. Если работодатель прекратил ведение деятельности или невозможно уста- 
новить его фактическое местонахождение, застрахованное лицо может самостоятельно с установленными законом документами обратиться за выплатой страхового обеспечения в территориальный орган ФСС по месту регистрации работодателя. Нововведения также обеспечивают правильность начисления пособий, сокращение спорных ситуаций с работодателем и отсутствие зависимости от него.

Таким образом, новая система взаимодействия ФСС со страхователями и застрахован- ными направлена на оптимизацию документооборота, переход на электронный обмен данными как внутри государственного аппарата, так и со сторонними участниками (медицинскими учреждениями, страхователями), а также на усиление контроля экспертизы временной нетрудоспособности. Результатом модернизации должны стать своевременные и правильно рассчитанные выплаты пособий застрахованным гражданам без лишних бюрократических проволочек.

\section{ЛИТЕРАТУРА}

1. Фонд социального страхования Российской Федерации. Пилотный проект «Прямые выплаты» [Электронный ресурс]. http://www.r54.fss.ru/69931/index.shtml.

2. Участники пилотного проекта ФСС [Электронный ресурс]. - Режим доступа: http://fss.ru/ru/news/2015/203203.shtml.

3. Реализация пилотного проекта [Электронный ресурс]. - Режим доступа: http://www.klerk.ru/buh/articles/345585/.

4. Преимущества пилотного проекта ФСС. [Электронный ресурс]. - Режим доступа: http://nalog-

nalog.ru/posobiya/posobie_po_vremennoj_netrudosposobnosti_bolnichnyj/pilotnyj_proe kt_fss_kak_uchastvovat_i_v_chem_preimuwestva/.

5. Карачаево-Черкесия - участник пилотного проекта [Электронный ресурс]. - Режим доступа: http://kchr.ru/news/detailed/5629/.

6. Первые итоги пилотного проекта [Электронный ресурс]. - Режим доступа: http://www.zarplata-online.ru/art/147048-pervye-itogi-pilotnogo-proekta-fss-rossii.

7. Силина, Т.А. Система выплат пособий по временной нетрудоспособности в Советской России // Современный научный вестник, 2016. Т. 7. № 2. - С. 29-35.

8. Карпенко, С.В. Пособия по болезни, беременности и родам: сто лет назад и сегодня //Современный научный вестник, 2016. Т. 8. № -2. - С. 38-44.

9. Силина, Т.А. Зарождение документальной фиксации нетрудоспособности работников в России/Т.А. Силина//Современный научный вестник, 2016. Т. 11. № -2. С 253256.

10. Карпенко, С.В. Декрет «О страховании на случай болезни» 1719 г. - первый шаг к современной системе страхования в России // Уральский научный вестник, 2016. T. 9. № 2. - С 99-104. 


\title{
ПОЛЬЗОВАТЕЛИ АУДИТА И АНАЛИЗ ИХ ИНФОРМАЦИОННЫХ ПОТРЕБНОСТЕЙ
}

Мирзова С.Г. студент, Адыгейский государственный университет, г. Майкоп Научный руководитель: Таусова И.Ф. к.э.н., доцент, Адыгейский государственный университет, г. Майкоп

\begin{abstract}
Аннотация: Данная статья посвящена пользователям аудита. Рассматривается классификация пользователей аудиторской информации, в зависимости от формы документов и содержания в них аудиторской информации.

Ключевые слова: аудит, пользователи аудита, аудиторская информация.
\end{abstract}

\section{USERS OF AUDIT AND THEIR INFORMATION NEEDS ANALYSIS}

\author{
Mirzova S.G. \\ student, Adyghe State University, Maykop \\ Research supervisor: Tausova I.F. \\ Cand.Econ.Sci., associate professor, Adyghe State University, Maykop
}

\begin{abstract}
This article focuses on the role of audit in the modern economy, as well as the users of the audit. We consider the classification users of the audit information, depending on the form of documents and content of the audit information. Keywords: audit, user's audit, audit information
\end{abstract}

В современном обществе организации с всевозможными формами собственности имеют возможность сами формировать производство, самостоятельно реализовывать любой вид продукции, выбирать методы бухгалтерского и налогового учета, использовать такую систему оплаты труда, которая подходила бы именно данному предприятию и многое другое. В этом случае также не стоит забывать, что государство контролирует все эти предприятия и важную роль в данной ситуации имеют как финансово-экономический контроль, так и обязательные аудиторские проверки.

Данная тема является очень актуальной, так как значение аудита в экономике на сегодняшний день очень велико, без него становится почти невозможным принятие такого решения, которое позволило бы предприятию эффективно вести бизнес, как в настоящем, так и в будущем. На основании этого, можно сказать, что проведенная вовремя аудиторская проверка позволяет объективно оценить деятельность организации и подобрать необходимый план действий для ее дальнейшего развития.

Под аудитом понимается независимая проверка организации, с целью выражения достоверности ее бухгалтерской и финансовой отчетности. Так как аудит является неразделимой частью рыночной экономики каждого государства, именно поэтому аудиторская деятельность в условиях рыночной экономики и в системе финансового контроля играет важную роль [1].

Потребность в услугах аудитора возникла в связи с обособлением интересов тех, кто непосредственно занимается управлением предприятием (администрация, менеджеры), кто вкладывает средства в его деятельность (собственники, акционеры, инвесторы), а также государства как потребителя информации о результатах деятельности предприятий. 
Наличие достоверной информации позволяет повысить эффективность функционирования рынка капитала и дает возможность оценивать и прогнозировать последствия принятия экономических решений.

Проведение аудиторской проверки даже в тех случаях, когда она не является обязательной, несомненно, имеет важное значение.

В условиях рынка предприятия, кредитные учреждения, другие хозяйствующие субъекты вступают в договорные отношения по использованию имущества, денежных средств, проведению коммерческих операций и инвестиций.

Доверительность этих отношений должна подкрепляться возможностью получать и использовать финансовую информацию всеми участниками сделок. Достоверность информации подтверждается независимым аудитором.

Собственники и прежде всего коллективные собственники - акционеры, пайщики, а также кредиторы не в состоянии самостоятельно убедиться в том, что все операции предприятия, многочисленные и зачастую очень сложные, законны и правильно отражены в отчетности, так как они обычно не имеют доступа к учетным записям и соответствующего опыта, а поэтому нуждаются в услугах аудиторов.

Независимое подтверждение информации о результатах деятельности предприятий и соблюдение ими законодательства необходимо государству для принятия решений в области экономики и налогообложения.

Аудиторские проверки необходимы и государственным органам, судьям, прокурорам и следователям для подтверждения достоверности интересующей их финансовой отчетности.

В условиях рынка предприятия являются независимыми производителями.
Однако финансовые результаты их деятельности интересуют достаточно большое количество пользователей информации, содержащейся в бухгалтерской (финансовой) отчетности.

Прежде всего, информация о деятельности предприятия интересует тех, кто входит в так называемые партнерские группы предприятия, т.е. непосредственно участвует в его финансовой и хозяйственной деятельности, вносит свой вклад в эту деятельность, требует компенсации за свой вклад и, исходя из своих интересов, анализирует информацию о предприятии.

Следует отметить, что не все группы пользователей имеют равный доступ к информации: только администрация и частично собственники могут анализировать все данные управленческого и финансового учета, бухгалтерской (финансовой) и другой отчетности. Остальные группы ограничены только данными публичной бухгалтерской (финансовой) отчетности.

Эти пользователи, потребители финансовой информации, непосредственно «жестко» заинтересованы в финансовых результатах деятельности предприятия, так как от этих результатов зависит их собственное финансовое благополучие, доходы бюджета.

Кроме того, существует еще одна довольно обширная группа пользователей финансово й отчетности, которые непосредственно не заинтересованы в результатах деятельности предприятия, но представляют и защищают интересы первой группы потребителей.

К ним относятся: аудиторы и аудиторские фирмы; консультанты по финансовым вопросам; специалисты в области ценных бумаг и фондовых бирж (брокеры и дилеры); юристы и юридические фирмы; регулирующие органы; пресса и информационные агентства; торгово-производственные агентства; широкая публика. 
Аудит выполняет несколько особо важных функций, например, таких как аналитическая функция, экспертная, консультацио нная, информационная, управленческая и производственная. Благодаря всем указанным функциям аудит, играет важную роль в экономике в целом, а также помогает не только улучшить финансовое состояние различных предприятий, но и избежать всевозможных рисков, возникающих из-за искажения бухгалтерских документов [3].

Если предприятие желает получить верную и полную информацию о своем финансовом состоянии или же просто подлежит обязательному аудиту, то ему необходимо обратиться за помощью к аудиторам. Найти такую аудиторскую компанию, которая смогла бы предоставить качественные услуги по осуществлению аудиторской проверки, так как данный вид деятельности требует компетентности и особой внимательности [4].

В данных условиях для всех, кто, так или иначе, связан с деятельностью предприятия возникает необходимость получить информацию о его деятельности. Аудитор выступает посредником между пользователями бухгалтерской отчетности и ее составителями.

И так рассмотрим, кто же может быть пользователем аудиторской информации, и с какой целью их интересует данная информация. Помимо предприятий примером пользователей аудиторской информации могут выступать: кредиторы, с целью получения процентов, инвесторы, собственники и руководители предприятия, покупатели, с целью получения работ, товаров и услуг, поставщики, ну и конечно государственные органы.

Информация, которая накапливается и анализируется аудиторами в процессе их работы над проектами, отражается в надлежащих внутренних рабочих документах индивидуальных аудиторов и аудиторских организациях, а также в формах отчетах, которые предоставляются клиентам [2]. Рассмотрим классификацию пользователей аудиторской информации, которая зависит от формы документов, а также содержания в них аудиторской информации.

Итак, первый вид документа, который составляет аудитор это план и программа аудита. Пользователями информации, которая представлена в данном документе являются:

1) руководитель группы аудиторов, который на основании предоставленной информации осуществляет контроль качества и сроков выполнения работ на разных участках;

2) аудитор, непосредственно осуществляющий проверку, использует данную информацию в качестве инструкции, в которой содержаться данные о последовательности, о взаимосвязи выполненных заданий, о сроках выполнения проверки на ее этапах;

3) руководство организации предоставляющей аудиторские услуги, а также руководство клиента, если это юридическое лицо или клиент - физическое лицо, на основе данного документа осуществляют контроль над исполнением договорных обязательств;

4) саморегулируемая организация аудиторов, на основе информации представленной в плане и программе аудита, осуществляют внешний контроль качества оказанных аудиторских услуг [5].

Пользователями рабочих документов аудиторов являются:

1) аудитор, который осуществляет проверку с целью сбора аудиторских доказательств, отражения сведений о проведении аудита и осуществлении сопутствующих аудиту услуг;

2) саморегулируемая организация аудиторов и руководитель группы аудиторов, на основе информации в аудиторских документах производят контроль внешний за оказанием аудиторских услуг и контроль качества осуществления работ на разных участках соответственно; 
3) индивидуальные аудиторы или сторонние аудиторские организации, целью которых является использование информации о результатах аудиторских услуг, которые были оказаны ранее, в процессе проведения первоначального аудита;

4) руководство аудиторской организации, используют рабочие документы аудитора с целью накопления информации о ранее предоставленных услугах, для их применения в дальнейшей деятельности организации.

Следующий вид документа, составляемый аудитором это отчет руководству аудируемого лица. Его пользователями являются:

1) руководство аудиторской организации;

2) собственники организации и руководство клиента, с целью корректировки первичных документов, данных бухгалтерской отчетности и бухгалтерского учета, а также их достоверности, оптимизации внутреннего контроля, оценки системы бухгалтерского учета;

3) министерства и ведомства, подчиняющие себе аудиторов, используют аудиторскую информацию для того, чтобы оценить существующую систему бухгалтерского учета и отчетности, а также реализовать имущественные и финансовые интересы государства;

4) индивидуальные аудиторы, сторонние аудиторские организации, саморегулируемая организация аудиторов и другие [6].

На заключительном этапе своей работы аудитор составляет заключение и отчет. Порядок оформления этих документов определяется нацио наль ным стандартом аудиторской деятельности №70 «Аудиторский отчет и аудиторское заключение о финансовой отчетности».

Аудиторское заключение представляет собой служебный документ, который содержит всю информацию о том, правильно ли ведется бухгалтерская отчетность на предприятии. При этом оценивается достоверность бухгалтерской отчетности и общая эффективность осуществляемой хозяйственной деятельности.

Заключение аудитора содержит:

1) наименование объекта (должность и ФИО аудируемого лица);

2) информацию о том, кто выполняет проверку;

3) информацию об объекте аудита;

4) вводную часть;

5) основную часть, в которой описывается проверка;

6) оценку, сделанная аудитором;

7) дату заключения и подпись лица, осуществляющего проверку.

Любое аудиторское заключение должно быть объективным и понятным, в нем должны содержаться все сведения, которые помогают реально оценить состояние проверяемого объекта или лица. Документ должен отражать то, как обстоят дела на предприятии в действительности.

Аудиторский отчет представляет собой документ, составленный для собственника, собрания акционеров, руководителя компании. В нем содержится подробная информация о том, как проходила проверка предприятии, какие нарушения были найдены в отчетности и иные важные сведения, на основании которых затем составляется аудиторское заключение.

Аудитор, выполнявший проверку финансовой отчетности компании, обязательно подписывает документ постранично и направляет его клиенту. Аналитическая часть отчета содержит итоги проверки бухгалтерской отчетности, оценку того, соответствует ли хозяйственная деятельность компании законодательству, проверку того, правильно ли ведется исчисление и уплата налогов и иных платежей. Кроме того, аудиторский отчет должен включать в себя общую оценку имеющейся системы контроля на предприятии и то, какие несоответствия при этом были обнаружены. 
Аудиторской информацией представленно й в таком документе как аудиторское заключение используют все вышеперечисленные пользователи аудита. Помимо них пользователем данной информации также являются 4 прочие государственные органы, в том числе суды, налоговые службы и прочие [5].

Подводя итог всему вышеизложенному можно сделать вывод, что в целом информа- ция, которая содержится в аудиторских отчетах и документах нужна и важна для пользователей аудита, так как данная информация позволяет оценить ее пользователям предполагаемую прибыль, выявить всевозможные точки риска, а также определить различные перспективы от взаимодействия с объектом аудита.

\section{ЛИТЕРАТУРА}

1. Альборов, Р.А. Аудит в организациях промышленности, торговли и АПК: учеб. пособие. - М.: Дело и сервис, 2013. - 458 с.

2. Богомолов, А.М. Внутренний аудит. Организация и методика проведения: учеб. пособие. - М.: Экзамен, 2014. - 192 с.

3. Данилевский, Ю.А. Аудит и основные направления аудиторской деятельности: учеб. пособие - М.: Изд. ФИПК, 2014. - 97 с.

4. Дегальцева, Ж.В. Аудит контрактных отношений в коммерческих организациях / Ж.В. Дегальцева, Т.А. Силина // Нормативные акты для бухгалтера Краснодарского края, 2007. № 11.- С. 15-18.

5. Куприянов, Е. М. Экономика предприятия: учеб. пособие. - М.: «АКДИ экономика и жизнь», 2012. - 342 с.

6. Четыркин, Е.М. Выборочные методы в аудите: практическое пособие. - М: «Дело», 2011. - $144 \mathrm{c}$.

7. Таусова, И.Ф. Концепции аудиторской деятельности: задачи, проблемы, решения // Приоритетные научные направления: от теории к практике, 2015. - С. 173-175. 


\title{
ОСОБЕННОСТИ БУХГАЛТЕРСКОГО УЧЕТА ДОБАВОЧНОГО КАПИТАЛА ОРГАНИЗАЦИИ
}

Намоев А.P. магистрант, Кубанский государственный университет, г. Краснодар Научный руководитель: Паздерова В.Ю. к.э.н., доиент, Кубанский государственный университет, г. Краснодар

\begin{abstract}
Аннотация. Добавочный капитал представляет собой особый элемент в составе источников собственных средств организаций, занимающий промежуточное положение между уставным капиталом и нераспределенной прибылью. Учетные операции по формированию и расходованию добавочного капитала как специффичного фонда строго регламентируются. В данной статье рассмотрены особенности осуществления и отражения в бухгалтерском учете операций с добавочным капиталом.

Ключевые слова: добавочный капитал, собственный капитал, переоценка внеоборотных активов, курсовая разниия по вкладу в уставный капитал, эмиссионный доход.
\end{abstract}

\section{PECULIARITIES OF ACCOUNTING OF ADDITIONAL CAPITAL} OF THE ORGANIZATION

Namoev A.R. undergraduate, Kuban state university, Krasnodar Research supervisor: Pazderova V.Yu. Cand.Econ.Sci., associate professor, Kuban state university, Krasnodar

\begin{abstract}
The additional capital is a special element in the structure of sources of own funds of organizations, occupying an intermediate position between share capital and retained earnings. Accounting operations for the formation and expenditure of additional capital as a specific Fund is strictly regulated. This article describes the peculiarities of implementation and reflection in accounting of operations with additional capital.
\end{abstract}

Keywords: additional paid-in capital, own capital, revaluation of fixed assets, exchange differences arising from the contribution to the authorized capital, the share premium reserve.

Положение по ведению бухгалтерского учета и бухгалтерской отчетности в Российской Федерации [1], определяющее порядок организации и ведения бухгалтерского учета, составления и представления бухгалтерской отчетности юридическими лицами, определяет добавочный капитал как элемент собственного капитала организации, для учета которого согласно Инструкции по применению плана счетов [2] предназначен счет 83 «Добавочный капитал».

Следует отметить, что Инструкция к плану счетов описывает две возможности возникновения добавочного капитала:
1) в результате переоценки внеоборотных активов. В этом случае добавочный капитал соответствует сумме прироста (дооценки) стоимости переоцененных активов;

2) в результате продажи акций в процессе формирования уставного капитала акционерного общества по цене, превышающей их номинальную стоимость. В этом случае добавочный капитал соответствует сумме разницы между продажной и номинальной стоимостью акций.

Кроме того, согласно п. 14 ПБУ 3/2006 «курсовая разница, связанная с расчетами с учредителями по вкладам, в том числе в уставный 
(складочный) капитал организации, подлежит зачислению в добавочный капитал этой организации» [3]».

Таким образом, возникновение добавочного капитала связано с процессами формирования уставного (складочного) капитала организации, главным образом, акционерного общества, и переоценки внеоборотных активов.

Что касается использования добавочного капитала, то «суммы, отнесенные в кредит счета 83 «Добавочный капитал», как правило, не списываются [2]». Инструкция по применению плана счетов содержит открытый перечень возможных случаев осуществления дебетовых записей по данному счету:

- погашение сумм снижения стоимости внеоборотных активов, выявившихся по результатам его переоценки (уценки);

- направление средств на увеличение уставного капитала;

- распределение сумм между учредителями организации;

- и т.п.

При первоначальном формировании или увеличении уставного капитала акционерного общества в случае, когда акции продаются по цене выше номинальной, образуется разница между продажной и номинальной стоимостью акций, называемая эмиссионным доходом или, что, на наш взгляд, более корректно, эмиссионной премией. Сумма превышения продажной цены акций над их номиналом, соответственно, отражается по кредиту счета 83 «Добавочный капитал» в корреспонденщии со счетом 75 «Расчеты с учредителями», субсчет 1 «Расчеты по вкладам в уставный (складочный) капитал». Аналогично отражается возникающее у общества с ограниченной ответственностью превышение стоимости вклада участника в уставный капитал общества над номинальной стоимостью оплаченной участником доли.
Кроме того, как отмечает автор [4] «разница между продажной и номинальной стоимостью акций может быть сформирована также за счет положительной (отрицательной) курсовой разницы в случае, когда взносы в уставный капитал вносятся иностранной валютой».

При этом, очевидно, что отрицательная курсовая разница по вкладам в уставный (складочный) капитал должна быть списана за счет положительных разнищ по аналогичным операциям, а при их недостаточности (или отсутствии), как считает автор [5, с. 3], «единственной статьей добавочного капитала, за счет которой может быть списана отрицательная курсовая разница по вкладам в уставный капитал, выступает эмиссионный доход».

Формирование и использование добавочного капитала при проведении переоценки внеоборотных активов, а именно, основных средств и нематериальных активов регламентируется ПБУ 6/01 [6] и ПБУ 14/07 [7], соответственно. При этом возникновение добавочного капитала обусловлено дооценкой балансовой (остаточной) стоимости указанных активов, а использование - уценкой. Таким образом, добавочный капитал, образовавшийся в результате дооценки внеоборотных активов, выступает источником их уценки.

В случае выбытия актива, относящийся к нему добавочный капитал, образовавшийся как результат переоценки, присоединяется к нераспределенной прибыли организации, a, значит, величина собственного капитала в итоге не изменяется.

Предусмотренная Инструкцией по применению плана счетов возможность распределения добавочного капитала между учредителями организации может быть реализована, как справедливо отмечено в статье [4], только в условиях ликвидации хозяйствующего субъекта, когда все фонды и резервы, включая добавочный капитал, списываются в кредит 
счета 75 «Расчеты с учредителями» с последующей выдачей средств участникам.

В заключение следует отметить, что операции с добавочным капиталом, особенно свя- занные с его использованием (списанием), целесообразно проводить в рамках тех направлений, которые определены Инструкцией по применению плана счетов.

\section{ЛИТЕРАТУРА}

1. Положение по ведению бухгалтерского учета и бухгалтерской отчетности в Российской Федерации: Приказ Минфина РФ от 29.07.1998 г. №34н (в ред. 24.12.2010 г.) // СПС КонсультантПлюс. - Москва, 2016.

2. План счетов бухгалтерского учета финансово -хозяйственной деятельности предприятий и инструкция по его применению: Приказ Минфина РФ от 31.10.2000 г. №94н (в ред. от 08.11.2010г.) // СПС КонсультантПлюс. - Москва, 2016.

3. Положение по бухгалтерскому учету «Учет активов и обязательств, стоимость которых выражена в иностранной валюте» (ПБУ 3/2006): Приказ Минфина РФ от 27.11.2006 г. №154н (в ред. от 24.12.2010г.) // СПС КонсультантПлюс. - Москва, 2016.

4. Орлова, О.Е. Добавочный капитал предприятий пищевой промышленности / О.Е. Орлова // Пищевая промышленность: бухгалтерский учет и налогообложение. - 2015. - №11 // СПС КонсультантПлюс. - Москва, 2016.

5. Паздерова, В.Ю. К вопросу об отражении курсовых разниц, возникающих по вкладам в уставный (складочный) капитал / В.Ю. Паздерова // Все для бухгалтера. 2006. - №24 (192). - С.2-4.

6. Положение по бухгалтерскому учету «Учет основных средств» (ПБУ 6/01): Приказ Минфина РФ от 30.03.2001 г. №26н (в ред. от 16.05.2016 г.) // СПС КонсультантПлюс. - Москва, 2016.

7. Положение по бухгалтерскому учету «Учет нематериальных активов» (ПБУ 14/2007): Приказ Минфина РФ от 27.12.2007 г. №153н (в ред. от 16.05.2016 г.) // СПС Консультант Плюс. - Москва, 2016. 


\title{
ПОНЯТИЕ, РОЛЬ И ПРИНЦИПЫ ФОРМИРОВАНИЯ И РАСКРЫТИЯ УЧЕТНОЙ ПОЛИТИКИ В РЫНОЧНОЙ ЭКОНОМИКЕ
}

Науменко Н.В. магистрант, Кубанский государственный университет, г. Краснодар Научный руководитель: Луговский Д.В. к. э. н., доцент, Кубанский государственньй университет, г. Краснодар

\begin{abstract}
Аннотация. В статье раскрыта экономическая сущность и роль учетной политики на современном предприятии. Критически проанализировано действующее определение учетной политики, рассмотрены основные допущчения и требования, лежашие в ее основе. Ключевые слова: учетная политика, оченочные значения, допущения, требования.
\end{abstract}

\section{CONCEPTION, ROLE AND PRINCIPLES OF FORMATION AND DISCLOSURE OF ACCOUNTING POLICIES IN MARKET ECONOMY}

Naumenko N.V. magistrant, Kuban state university, Krasnodar Research supervisor: Lugovsky D.V. cand. econ. sci., associate professor, Kuban state university, Krasnodar

\begin{abstract}
The article deals with economic essence and role of accounting policies in the modern enterprise. Critically analyzed the current definition of accounting policies, the basic assumptions and requirements behind it.

Key words: accounting policies, estimates, assumptions, requirements.
\end{abstract}

По справедливому замечанию профессора М.И. Кутера «учетную политику по праву называют ключевой категорией бухгалтерского учета ... Она возникает, когда бухгалтер, помимо констатации объективных хозяйственных процессов (например, выплата денег), не имеющих альтернативного толкования, начинает допускать предположения о наличии определенных условий или не существующих в реальности событий (например, исчислять финансовый результат или распределять накладные расходы), чтобы получить информацию, необходимую главным образом для анализа эффективности работы предприя тия. И как только это происходит, отчетные данные превращаются из фотографии в картину хозяйственного процесса, в которой неизбежно присутствуют субъективные представления ее автора» [4, с. 482-483].

Поэтому, учетная политика - есть ни что иное, как выбор среди альтернатив отражения в учете фактов хозяйственной жизни.
Этот выбор, может быть осуществлен как на уровне государства или группы государств (глобально), посредством издания законодательных и нормативных актов, так и на уровне предприятия или группы предприятий (локально) в рамках допустимых на предыдущем уровне альтернатив.

В части многих хозяйственных операций нормативные и законодательные акты содержат безальтернативные предписания, допускающие лишь единственный вариант их учетного отражения. Тем не менее принятию единственно правильного решения способствует бухгалтерское профессиональное суждение.

В некоторых случаях бухгалтерские стандарты носят вариативный характер - допускают наличие альтернатив в учете. Число таких иногда может быть велико, но всегда не менее двух. К наиболее распространенным случаям, когда требуется выбор, относится 
установление способа начисления амортизации долгосрочных активов, способов списания стоимости запасов.

Также возможна ситуация, при которой вариативность обусловлена наличием противоречий в законодательстве, его коллизионностью. Задача бухгалтеру заключается в попытке разрешения противоречия на основе своего профессионального суждения.

И, наконец, имеют место хозяйственные операции, порядок учета которых не регламентируются. По мнению доцента Д.В. Луговского «бухгалтерское законодательство не в состоянии охватить всего многообразия хозяйственной жизни и предусмотреть все возможные случаи. При этом выбор также имеет место, однако определять его поле, а не только осуществлять этот выбор, должна сама организация, основываясь на профессиональном бухгалтерском суждении. Это, например, выбор базы для распределения накладных расходов или способа списания расходов будущих периодов» [5, с. 100].

Можно констатировать, таким образом, наличие трех базовых подходов к определению способов ведения бухгалтерского учета организацией - централизованного, децентрализованного и смешанного. Соответственно, в первом случае базовые правила и принципы ведения учета регламентируются государством из центра.

Второй вариант допускает индивидуализацию правил ведения учета для бизнес-субъектов. Принято считать, что при нем достигается максимальная адекватность способов учета особенностям функционирования организации. Однако, абсолютная либерализация недопустима даже в условиях рынка.

Поэтому на практике в большинстве случаев преобладает разумное сочетание централизованного регулирования и допустимых свобод.

В России термин «учетная политика» впервые появился в конще восьмидесятых годов
XX века как перевод словосочетания «accounting policies», употребляемого в тексте Международных стандартов финансовой отчетности. В 1992 г. этот он был официально принят в Положении о бухгалтерском учете и отчетности в РФ (сегодня - Положение по ведению бухгалтерского учета и бухгалтерской отчетности в РФ [10]), а в 1994 г. - в Положении по бухгалтерскому учету «Учетная политика предприятия» (в настоящее время - ПБУ 1/08 «Учетная политика организации» [11]) и стал широко использоваться.

Положение содержит следующее определение: «Учетная политика организации - это принятая ею совокупность способов организации и ведения бухгалтерского учета (первичного наблюдения, стоимостного измерения, текущей группировки и итогового обобщения фактов хозяйственной жизни)» [1].

Данное определение носит процедурный характер и базируется на реализации учетной политики в рамках современной учетной методологии. А именно, учетная политика рассматривается как средство реализации метода бухгалтерского учета. А поскольку сам метод бухгалтерского учета как науки включает в себя четыре элемента - первичное наблюдение, стоимостное измерение, текущую группировку и итоговое обобщение, - то и определение учетной политики практически дублирует определение метода, почти сливаясь с ним. В этом, на наш взгляд, его основной недостаток, который приводит к крайне распространенному среди представителей бухгалтерской профессии непониманию сущности этого важнейшего процесса и явления. Ключевое слово этого определения - это слово «принятая» (более удачный синоним - выбранная, избранная), которое очень часто остается «за кадром». Следующая далее «совокупность способов ...» и их расшифровка 
вторична. Более того, ее присутствие в определении не является определяющим, она, наоборот, отвлекает внимание от главного.

Среди четырех перечисленных элементов метода к учетной политике в настоящее время непосредственное отношение имеет лишь два - текущая группировка, и стоимостное измерение, осуществляя которые бухгалтер производит идентификацию, классификацию и оценку фактов хозяйственной жизни. Заметим при этом, что к учетной политике можно отнести далеко не все вопросы оценки, а лишь ту их часть, которая связана с определением (выбором) ее способов. Изменение оценки согласно ПБУ 21/08 не относится к учетной политике, а признается изменением оценочного значения. Первичное наблюдение и связанный с ним выбор не влияет на учетные данные и относится к организационному аспекту. То же самое можно сказать и об итоговом обобщении.

К учетной политике относится лишь выбор того или иного способа учета. Например, оценка запасов осуществляется либо по средней себестоимости, либо по себестоимости первых по времени закупок, либо по себестоимости каждой единицы; стоимость объектов основных средств погашается линейным способом, способом уменьшаемого остатка, способом суммы числе лет срока полезного использования, пропорционально объему выпиленных работ, услуг, произведенной продукции. Из всего многообразия методов организация вправе выбрать те, посредством использования которых обеспечивается формирование достоверной информации о ее финансовом положении и финансовом результате. При этом принятые способы ведения учета должны находиться в определенных рамках.

Учетная политика, как средство реализации метода бухгалтерского учета, будет отличаться в зависимости от масштабов, вида деятельности организации и других факторов.
При этом основная задача учетной политики максимально достоверно представить финансово-хозяйственную деятельность предприятия, сформировать полную, объективную и достоверную информацию о ней для целей эффективного регулирования этой деятельности в интересах широкого круга пользователей финансовой отчетности.

Учетная политика «формируется посредством выбора тех или иных способов ведения учета из допускаемых действующими стандартами. Если стандартами не установлены такие способы ведения учета тех или иных объектов, то экономический субъект самостоятельно разрабатывает соответствующие процедуры исходя из требований законодательства и нормативных актов по бухгалтерскому учету. В любом случае должно быть выдержано единство учетной политики. Оно состоит в том, что выбор способов построения учетной системы осуществляется на единых принципах. Это означает, во-первых, применение избранных способов всеми структурными подразделениями компании, включая выделенные на отдельный баланс, независимо от места их нахождения. В противном случае формируемая разными подразделениями учетная информация будет несопоставимой и несводимой. Во-вторых, в отношении какого-то одного конкретного вопроса организация должна использовать только один выбранный способ. Кроме того, формирование учетной политики сегодня необходимо, как минимум, в двух информацио нных областях в бухгалтерском финансовом и налоговом учете» [6, с. 23].

ПБУ 1/08 «Учетная политика организации» для обозначения бухгалтерских принципов, лежащих в основе ее формирования, использует понятия «требования» и допущения». Между тем ни один нормативный или методический источник не содержит расширенно й трактовки данных формулировок. Несмотря 
на кажущуюся очевидность категорий, при анализе их содержания на практике часто возникает вопрос: в чем разница между допущениями и требованиями?

Допущение подразумевает «объективное наличие какого-либо условия, предположения, гипотезы, т. е. указывает не на обязательность, а на предположительность определенного факта. Требование имеет ввиду неукоснительность выполнения указанного положения, а его реализация целиком зависит от субъективной воли исполнителя. Или, пользуясь языком философии, допущение представляет собой объективную реальность, а требование - осознанную необходимость. Таким образом, следует выделить два основополагающих отличия (необходимое и достаточное)» [3, с. 52].

Предназначение требований и допущений состоит в обеспечении сопоставимости и достоверности информации, включая нефинансовую. ПБУ 1/08 выделяет четыре допущения и шесть требований. К допущениям относятся: «имущественная обособленность, непрерывность деятельности, последовательность применения учетной политики, временная определенность фактов хозяйственно й жизни» [1].

При разработке учетной политики, прежде всего, отталкиваются от того, что имущество и обязательства организации обособлены от имущества и обязательств ее владельцев и иных лиц. Данный подход подчеркивает юридическую обособленность активов фирмы и активов других субъектов гражданских правоотношений, в том числе учредителей организацией. В результате в учете находит отражение одна из важнейших норм гражданского права, определяющая юридический субъект правоотношений - в данном случае - юридическое лицо (организацию), которая имеет имущество, принадлежащее ей (а не ее учредителям) на праве собственности и принимает на себя обязательства, по которым собственники не отвечают, если только речь не идет о ликвидации организации. Из данного принципа, логически проистекает следующий.

Принцип непрерывности деятельности организации означает ее намерение и возможность продолжать свою деятельность в будущем, у нее отсутствуют намерения ликвидироваться или существенно сокращать масштабы деятельности. В противном случае, вопервых, ставится под сомнение предыдущее допущение (имущественной обособленности), поскольку в случае ликвидации организации ее имущество и обязательства переходят к третьим лицам и собственникам (в зависимости от правовой формы общества и других факторов), а во-вторых, изменяется подход к применению многих способов бухгалтерского учета, прежде всего, к оценке активов и обязательств и резервированию.

Последовательное применение учетной политики означает, что принятые организацией способы ведения бухгалтерского учета применяются последовательно от одного отчетного периода к другому, т. е. предполагается постоянство избранной методики отражения фактов хозяйственной жизни, оценки имущества и обязательств в течение предстоящего финансового года и в обозримом будущем.

Временная определенность фактов хозяйственной жизни (или в западной терминологии, метод начислений) означает, что данные факты «относятся к тому отчетному периоду, в котором они имели место, независимо от фактического времени поступления или выплаты денежных средств, связанных с ними» [1].

Выбор учетной политики также должен производится с обязательным соблюдением следующих требований, обеспечивающих адекватность учетной политики условиям хозяйствования. В их состав входят следующие: «полнота, осмотрительность (осторожность), 
приоритет содержания перед формой, непротиворечивость, рациональность» [1].

Принятая организацией учетная политика должна обеспечивать полноту отражения в учете всех фактов хозяйственной жизни (хозяйственных операций, активов, капитала, обязательств, доходов и расходов).

Применяемые предприятием способы учета должны быть ориентированы на первоочередное признание в бухгалтерском учете потерь (расходов) и обязательств, нежели доходов и активов.

Приоритет содержания перед формой призван обеспечить отражение в бухгалтерском учете фактов хозяйственной жизни исходя из их экономического содержания, а не только юридической формы, в которую они облачены.

Непротиворечивость подразумевает, что избранные организацией учетные способы не нарушат соответствие данных синтетического и аналитического учета, взаимоувязки показателей бухгалтерской отчетности.

Кроме того, учетная политика должна обеспечивать максимально рациональную и эффективную организацию учетного процесса, чтобы при минимуме затрат обеспечить достаточность учетных и отчетных данных и их необходимый качественный уровень.

Несоблюдение перечисленных допущений и требований без веских причин может исказить данные финансовой отчетности. Более того, если отступление от основных допущений в ряде случаев возможно (поэтому они и именуются допущениями), то нарушение установленных требований неприемлемо. Так, например, допущение о непрерывности деятельности не применимо в условиях прекращения деятельности (в соответствии с требованиями ПБУ 16/02 «Информация по прекращаемой деятельности»).

Таким образом, принятая, на основе представленных допущений и требований, учетная политика обеспечивает единство системы бухгалтерского учета экономического субъекта и охватывает все аспекты учетного процесса. Методический аспект определяет, какие конкретно способы оценки активов и обязательств, начисления амортизации, признания доходов и расходов применяются предприятием. Организационный аспект отвечает за техническую реализацию этих способов в первичных документах, учетных регистрах, отчетности, а также с точки зрения структуры и полномочий бухгалтерской службы, ее места в системе управления организацией. Налоговый устанавливает способы определения налоговой базы из числа допустимых налоговым законодательством, избраны организацией. Традиционно раскрытию подлежат только методический и налоговый аспекты учетной политики.

\section{ЛИТЕРАТУРА}

1.Положение по бухгалтерскому учету «Учетная политика организации» (ПБУ $1 / 08)$ : Приказ Минфина РФ №106н от 06.10.08 г. (в ред. от 06.04.15 г.) // СПС КонсультантПлюс. - Москва, 2016.

2. Кутер, М.И. Проблемы формирования учетной политики в условиях перехода к международным стандартам финансовой отчетности (МСФО) / М.И. Кутер, Д.В. Луговской, Н.Ф. Таранец // Внедрение МСФО в кредитной организации, 2005. №1. - С. 25-30.

3. Кутер, М.И. Принципы бухгалтерского учета основа построения учетной политики / М.И. Кутер, Д.В. Луговской Д.В., Е.И. Хакноев // Бухгалтерский учет, 2001. №24. - C. 52-54. 
4. Кутер, М.И. Введение в бухгалтерский учет. - Краснодар: Просвещение-Юг, 2014. $-512 \mathrm{c}$.

5. Луговский, Д.В. Учетная политика и оценочные значения: сущность, содержание, взаимосвязь // Вестник Адыгейского государственного университета. Серия 5: Экономика, 2014. №2. - С. 98-106.

6. Мосин, В.Г. Методические основы экономической оценки производственно -хозяйственной политики предприятия: диссертация ... кандидата экономических наук: 08.00.05. - Новосибирск, 1998. - 175 с.

7. Ордынская, М.Е. Учетная политика как важнейший этап текущего налогового планирования / М.Е. Ордынская, С.В. Карпенко, Т.А. Силина // Совершенствование налогообложения как фактор экономического роста: материалы II Всерос. науч. конф. - Ставрополь, 2010. - С.115-118.

8. Силина, Т.А. Формирование управленческой учетной политики / Т.А. Силина, С.В. Карпенко // Экономика и управление в современных условиях: проблемы и перспективы: сб. науч. тр. междунар. науч.-практ. конф. - Майкоп: изд-во АГУ, 2014. C.116-120. 


\title{
ФИНАНСОВО-ЭКОНОМИЧЕСКИЕ АСПЕКТЫ РАЗВИТИЯ ТУРИЗМА В РЕСПУБЛИКЕ АДЫГЕЯ
}

Hexaй A.X. студент, Адыгейского государственного университета, г. Майкоп Научный руководитель: Силина Т.А. к.э.н., доцент, Адыгейский государственный университет, г. Майкоп

\begin{abstract}
Аннотация: в статье исследуются перспективы развития индустрии туризма в Республике Адыгея, на основе формирования транспортной инфраструктуры, стимулирования спроса на туристско-рекреационный комплекс, привлечения государственных и частных инвестиционных вложений в туристические проекты.

Ключевые слова: туризм, инвестиции, Адыгея, туристско-оздоровительная отрасль, аэропорт, сельский туризм.
\end{abstract}

\section{FINANCIAL AND ECONOMIC ASPECTS OF DEVELOPMENT OF TOURISM IN THE REPUBLIC OF ADYGEA}

Nekhay A. Kh.

student, Adygey state university, Maykop Research supervisor: Silina T.A.

Con. Econ. Sci., associate professor, Adygey state university, Maykop

\begin{abstract}
The article analyzes the prospects of development of the tourism industry in the Republic of Adygea, based on the development of transport infrastructure, to stimulating demand for tourist and recreational complex, attracting public and private investments in tourism projects.

Keywords: tourism, investment, Adygea, tourist and recreational industry, airport, rural tourism.
\end{abstract}

Стратегия импортозамещения, реализуемая в настоящее время, в том числе способствует успешному развитию отечественной туристической отрасли.

Статистика показывает, что именно в глубинку сейчас стремятся на отдых многие жители мегаполисов - это мировой тренд. Большой город - это большой стресс, люди устают от жизни в больших городах, от плохой экологии, скопления людей, спешки и т.д. Все это открывает сельскому туризму огромные перспективы и со временем они будут только нарастать.

В ряде стран сельский туризм продвигают десятки лет. Россия в этом отношении отстает, поэтому крайне важно анализировать и систематиз ировать тот опыт, который нарабатывается в разных концах страны. Сельский туризм не требует больших вложений, но при этом имеет огромное социальное значение. Зачастую это единственный инструмент сохранения отдаленных населенных пунктов. Поэтому разработка программ поддержки таких инициатив (в том числе в форме грантов) приобретает не только экономическое, но и социаль ное значение.

Адыгея традиционно считается аграрным и экологически благополучным регионом с богатой историей и традициями, поэтому ее потенциал для развития туризма, в том числе сельского, очень высокий. Сегодня есть спрос не только на активные виды отдыха, но и на познавательный туризм. Многие отдыхающие хотят увидеть отличительные особенности региона, больше узнать о жителях Адыгеи, местном укладе жизни, познакомиться с историей, культурой региона, особенно национальной кухней. Это раскрывает возможность более равномерного развития 
туризма - не только в горной местности. К примеру, личные подворные хозяйства в аулах и станицах могут стать экскурсионным и объектами, где можно организовать этнические подворья с воспроизводством старинных ремесел, демонстрацией приготовле ния адыгейского сыра и традиционных национальных блюд. При этом каждый гость должен постоянно ощущать домашний комфорт и повышенное персональное внимание.

В этом плане можно привести весьма перспективный проект создания экопарка «Черкесский сад». На участке, помимо мощного сада, планируется создать традиционное адыгское подворье: ремесленная мастерская, кухня, конюшня — таким образом, у гостей региона появится возможность познакомиться с различными гранями истории, древних обычаев и традиций народов Адыгеи. Это позволит превратить «Черкесский сад» в настоящий образовательно-этнографический туристический комплекс [1].

Также туристов можно привлечь путешествиями по чайному маршруту, который находится в посёлке Цветочном Майкопского района, где находятся плантации адыгейского чая, выведенного в 2010 г., а также плантация 1938 г., пережившая Великую Отечественную войну, где до сих пор собирают урожай.

Кроме чая, здесь растут хурма, унаби (китайский финик), азимина, инжир, гранат, грецкий opex, 21 сорт фундука, которые также будут интересны туристам.

Основное направление туризма в Адыгее активный отдых. В последнее время набирает популярность событийный туризм, который развивается на основе государственно-частного партнёрства. Проведение массовых туристских фестивалей уже становится традицией. Акцент делается на гастрономические фестивали, поскольку до 40\% туристов выбирает место отдыха, ориентируясь на свои гастрономические предпочтения.
В Республике за счет средств частных инвесторов возведены около 150 туристических объектов и построены гостиницы более чем на 6 тыс. мест.

В развитие туризма в Адыгее с 2014 года по настоящее время привлечены инвестиции на 800 млн р. Средства пошли на развитие инженерной и транспортной инфраструктуры отдыха и продвижение турпродуктов.

В частности, в рамках федеральной целевой программы по развитию туризма в Адыгее создается туристско-рекреационный кластер «Ворота Лаго-Наки», протянуты 25 км линий газопроводов, более 70 км магистральных водоводов и созданы сопутствующие объекты инженерно-технического обеспечения мест отдыха [3].

Хорошая сеть автодорог, близость к крупным и курортным городам Юга России, а также благоприятные климатические условия позволяют развивать в Адыгее туризм без серьёзных сезонных колебаний.

Однако, в республике практически не развиты другие виды транспортного сообщения. В целях решения этой проблемы глава Адыгеи А.К. Тхакушинов в сентябре 2016 г. обсудил с министром обороны РФ С.К. Шойгу вопрос о возможности двойного базирования военного аэропорта, расположенного в нескольких километрах от столицы республики, чтобы он мог принимать гражданские самолеты.

Железнодорожные ветки Северо-Кавказской железной дороги проходят по территории Республики Адыгея в Тахтамукайском, Кошехабльском, Гиагинском, Майкопском районах. Имеются подъездные дороги к станциям железных дорог в поселке Энем, ауле Шенджий, хуторе Псекупс, городе Майкопе, станице Гиагинской, ауле Кошехабль, поселке Каменномостском.

В соответствии со стратегией социальноэкономического развития Республики Адыгея до 2025 г., утвержденной Законом республики 
Адыгея от 23 ноября 2009 г. №300 «О Стратегии социально-экономического развития Республики Адыгея до 2025 года» (с последующими изменениями), в части развития пассажирского транспорта планируется создание в Республике Адыгея эффективной пассажирской транспортной системы, отвечающей современным потребностям общества и перспективам социально-экономического развития Республики Адыгея, обеспечивающей повышение уровня транспортного обслуживания жителей и гостей Республики Адыгея путем развития устойчиво функционирующе й, экономически эффективной, привлекатель но й и доступной для всех слоев населения системы пассажирского транспорта.

Реализация этих проектов позволит снять инфраструктурные ограничения и увеличить туристический поток в республику.

Государство может принять целый ряд мер по сохранению финансовой основы деятельности туристско-рекреационного комплекса, стимулированию спроса на его услуги. В частности следующее:

- необходимо совершенствовать и развивать методологию лицензирования, стандартизации, сертификации в сфере туризма; таможенное регулирование; законодательную базу;

- государство также должно обеспечить совершенствование нормативно-правово й базы санаторно-курортного дела. В частности, необходим новый закон о курортном деле. Он должен в том числе, предусматривать механизм согласования национальных, межотраслевых, региональных и местных интересов; обеспечивать приоритетность действия курортного права на курортных территориях; предусматривать компенсации курортам со стороны производств, снижающих их лечебный потенциал и конкурентные позиции на рынке;
- необходимо создать механизм реализации действующей в настоящее время нормы федерального закона о запрете на перепрофилирование здравниц, нецелевое использование курортных земель. Нужны специальные требования в сфере градостроительства, механизм разрешения споров между санаторным и учреждениями и организациями туристскорекреационной сервисной инфраструктуры;

- сегодня необходимо создание на уровне Правительства России органа, отвечающего за положение дел санаторно-курортном комплексе;

- государство в соответствии с федеральным законом от 23 февраля 1995 г. №26-Ф3 «О природных лечебных ресурсах, лечебнооздоровительных местностях и курортах» и учитывая передовой мировой опыт, должно обеспечить поддержку общественной инженерной инфраструктуры, целесообразно довести вертикаль государственного управления курортным делом до федеральных и региональных курортных территорий;

- следует продолжить оправдавшую себя практику целевого программного планиров ания развития туризма в регионе. В качестве источников финанс ирования этих программ целесообразно определять часть федеральных и региональных налогов, закрепляя эти средства в качестве государственной собственности;

- целесообразно подвергать льготному налогообложению средства туристских предприятий, санаторно-курортного комплекса, направленные ими из прибыли на капстроительство, НИР, увеличить норматив средств, направленных на обучение персонала, рекламу, и включаемых в состав затрат себестоимости услуг;

- вывести в определенных размерах из налогообложения доходы физических лиц, использованные на оплату санаторно-курорт- 
ных услуг; шире использовать механизм страхования организациями своего персонала, часть средств от которого направлять на санаторно-курортное лечение с включением этих затрат в себестоимость услуг; создать специальный курортный внебюджетный фонд, через который с использованием европейского опыта наладить оплату санаторно-курортного лечения граждан.

- создать благоприятные условия для инвестиций в туризм; увеличение инвестиций в человеческий капитал;

- решить проблемы адресного социального туризма;

- предоставлять активную помощь государства (как на местном, так и федеральном уровнях) в организации рекламы туристских возможностей регионов России, формирования имиджа региона;
- необходимо отслеживать динамику развития туризма и прогнозировать его вклад в экономику региона и страны в целом для полноценного развития туристской отрасли; для этого надо вести государственную статистику.

В современной ситуации государственное регулирование развития и использования экономического потенциала Адыгеи как национального государственного образования должны быть принципиально иным.

Масштабность и важность туризма свидетельствует о его принадлежности к стратегическим отраслям экономики региона, что требует непосредственного государственного регулирования, с целью обеспечения пропорциональности развития территориальных и отраслевых народнохозяйственных комплексов, обоснования политики занятости, обеспечения роста бюджетных доходов и управления состоянием платежного баланса.

\section{ЛИТЕРАТУРА}

1. Комитет по туризму и курортам Республики Адыгея [Электронный ресурс]. - Режим доступа: http://www.adygcomtur.ru/news.php?id=941\&print=yes .

2. Информационное агентство Адыгея сегодня [Электронный ресурс]. - Режим доступа: http://adigeatoday.ru/?article_id=27245.

3. Свободная Пресса-Юг [Электронный ресурс]. - Режим доступа: http://yug.svpressa.ru/travel/news/140703/.

4. Aviation Explorer «Содружество авиационных экспертов»[Электронный ресурс]. Режим доступа: http://www.aex.ru/news/2016/9/23/160026/. 


\title{
АНАЛИЗ ЗАКОНОДАТЕЛЬНОЙ БАЗЫ ПО УЧЕТУ РАСХОДОВ БУДУЩИХ ПЕРИОДОВ
}

Ордынская М.E. канд. экон. наук, доцент Адыгейский государственный университет, г. Майкоп Нестерова И.Л. магистрант, Адыгейский государственный университет, г. Майкоп

\begin{abstract}
Аннотация: Реформирование бухгалтерского учета в России ведет к постепенному обновлению нормативно-правовой базы и сближению ее с МСФО. В статье рассматриваются особенности формирования в учете и отчетности информации о расходах будущих периодов в свете действующего законодательства.

Ключевые слова: расходы будущих периодов, затраты, активы, бухгалтерский учет, нормативно-правовое регулирование, МСФО.
\end{abstract}

\section{ANAL YSIS OF THE LEGAL FRAMEWORK FOR ACCOUNTING OF EXPENSES PREPAID}

Ordynskaya M.E. Cand. Econ.Sci., associate professor, Adygei state university, Maikop Nesterova I.L. undergraduate, Adyghe State University, Maikop

\begin{abstract}
Accounting reform in Russia led to the gradual renewal of the regulatory framework and its convergence with IFRS. The article discusses the features of the formation of the accounting and reporting information on the costs of the future periods in the light of current legislation. Keywords: prepaid expenses, costs, assets, accounting, legal regulation, IFRS.
\end{abstract}

Российский учет расходов будущих периодов требует особого внимания из-за отсутствия единого универсального подхода к учетному процессу данных активов. Положением по ведению бухгалтерского учета и бухгалтерской отчетности №34н были аннулировано понятие «расходы будущих периодов». Однако, внеся изменения в Положение №34н, Минфин России не откорректировал связанные с ним документы нормативного и методического уровня по регулированию бухгалтерского учета, что влечет за собой неоднозначное интерпретацию действующих нормативно-правовых документов в области учета расходов будущих периодов. Таким образом, они существуют как объект бухгалтерского учета согласно указанным документам и не существуют в соответствии с Положением №34H.

До 2011 г. согласно п. 65 Положения по ведению бухгалтерского учета организации могли самостоятельно признавать в качестве расходов будущих периодов любые расходы, осуществленные в текущем отчетном году, но касающиеся будущих периодов. Более того, организации имели право самостоятельно определять порядок списания таких расходов в течение периода, к которому они относятся.

Современная редакция п. 65 Положения не содержит упоминания о праве организации самостоятельно квалифицировать какие-либо расходы в качестве расходов будущих периодов. Пункт 65 Положения гласит: «Затраты, произведенные организацией в отчетном периоде, но относящиеся к следующим отчетным периодам, отражаются в бухгалтерском балансе в соответствии с условиями признания активов, установленными нормативным и правовыми актами по бухгалтерскому учету, и подлежат списанию в порядке, установленном для списания стоимости активов данного вида» [1]. 
Для учета расходов будущих периодов используется одноименный счет 97, но только в тех случаях, когда надлежащие указания содержатся в действующих ПБУ. Прямые указания по учету расходов будущих периодов содержатся в двух ПБУ - ПБУ 14/2007 «Учет нематериальных активов» и ПБУ 2/2008 «Учет договоров строительного подряда».

Например, в п. 39 ПБУ 14/2007 говорится, что «фиксированные разовые платежи в рамках лицензионного договора на предоставление права использования результатов интеллектуальной деятельности или средств индивидуализации, отражаются в бухгалтерском учете лицензиата как расходы будущих периодов и подлежат списанию в течение срока действия договора [2].
Пункт 16 ПБУ 2/2008 гласит, что: «расходы, понесенные в связи с предстоящими работами по договору строительного подряда, учитываются как расходы будущих периодов и списываются по мере признания выручки для определения финансового результата» [3].

Механизм переноса затрат на будущее предусмотрен также п. 19 ПБУ 10/99 «Расходы организации».

Итак, в таблице 1 обобщены нормативные документы, затрагивающие учет расходов будущих периодов, несмотря на то, что в Положении по ведению бухгалтерского учета и бухгалтерской отчетности указанное понятие было аннулировано.

\section{Таблица 1 - Перечень нормативных (методических) документов,} содержащих рекомендации по отражению расходов будущих периодов

\begin{tabular}{|c|c|}
\hline $\begin{array}{l}\text { Нормативный } \\
\text { (методический) } \\
\text { документ }\end{array}$ & Текст документа \\
\hline $\begin{array}{lr}\text { Пункт } 39 & \text { ПБУ } \\
14 / 2007 & \text { «Учет } \\
\text { нематериальных } \\
\text { активов» }\end{array}$ & $\begin{array}{l}\text { зафиксированные разовые платежи в рамках лицензионного договора на } \\
\text { предоставление права использования результатов интеллектуальной } \\
\text { деятельности или средств индивидуализации, находят отражение в } \\
\text { бухгалтерском учете лицензиатакак расходы будущих периодов и списываются } \\
\text { во время действия договора }\end{array}$ \\
\hline $\begin{array}{l}\text { План счетов } \\
\text { бухгалтерского } \\
\text { учета финансово- } \\
\text { хозяйственной } \\
\text { деятельности } \\
\text { организаций }\end{array}$ & $\begin{array}{l}\text { счет } 97 \text { «Расходы будущих периодов» используется с целью обобщения данных } \\
\text { о расходах, осуществленных в отчетном периоде, но относящихся к будущим } \\
\text { периодам. Например, здесь можно отражать расходы, связанные с горно- } \\
\text { подготовительными работами; с работами, носящими сезонный характер; с } \\
\text { освоением новых производств, установок и агрегатов; рекультивацией земель } \\
\text { и других природоохранных мероприятий; неравномерно производимым в } \\
\text { течение года ремонтом основных фондов и т.д. }\end{array}$ \\
\hline $\begin{array}{lr}\text { Пункт } 16 & \text { ПБУ } \\
2 / 2008 & \text { «Учет } \\
\text { договоров } & \\
\text { строительного } \\
\text { подряда» } \\
\end{array}$ & $\begin{array}{l}\text { расходы, понесенные в связи с грядущими работами по договору } \\
\text { строительного подряда, учитывают в качестве расходов будущих периодов и } \\
\text { списывают по мере признания выручк для определения финансового } \\
\text { результата }\end{array}$ \\
\hline $\begin{array}{l}\text { Пункт } 19 \quad \text { ПБУ } \\
10 / 99 \quad \text { «Расходы } \\
\text { организации» }\end{array}$ & $\begin{array}{l}\text { расходы признаются в отчете о финансовых результатах посредством их } \\
\text { обоснованного распределения между отчетными периодами, если расходы } \\
\text { влекут к получению доходов в течение нескольких отчетных периодов и если } \\
\text { связь между доходами и расходами не может быть определена четко или } \\
\text { определяется косвенным путем }\end{array}$ \\
\hline
\end{tabular}

Что касается остальных случаев, то если у организации некоторого актива, то в балансе произведенные расходы повлекли появление признают его наличие. В противном случае 
произведенные расходы признаются в качестве расходов отчетного периода.

Следует иметь в виду, что система нормативного регулирования российского бухгалтерского учета устанавливает правила учета далеко не для всех видов активов. Например, нигде не закреплены правила учета затрат на разработку сайта. Хотя сайт организации, например, можно признать активом и способен принос ить экономические выгоды в будущем. Рассмотрим те категории расходов, которые явно не являются текущими, но приводят к появлению у организации таких активов, способы учета которых нигде не определены: затраты на создание сайтов; расходы на приобретение лицензий на право ведения некоторых видов деятельности; затраты на сертификацию, получение разного рода разрешений и т.д.; затраты на дорогой ремонт основных средств с большим временным шагом [4, с. 121].

Рекомендации по учету перечисленных выше расходов даны в письме Минфина России от 12.01.2012 №07-02-06/5. В нем говорится, что если затраты соответствуют условиям признания определенного актива, установленным нормативными правовыми актами по бухгалтерскому учету (ПБУ 6/01, ПБУ 5/01 и др.), то их следует отражать в балансе в составе этого актива и списывать в порядке, установленном для списания стоимости этого актива. В противном случае эти затраты отражают в балансе в качестве расходов будущих периодов и списывают посредством распределения между отчетными периодами в порядке, принятом в организации в течение периода, к которому они относятся.

Кроме того, в составе расходов будущих периодов можно учесть приобретение бухгалтерских программ.

Что касается отражения расходов будущих периодов в бухгалтерском балансе, то отдельная статья для отражения расходов будущих периодов в настоящее время в балансе отсутствует. Информация о расходах будущих периодов в части расходов, срок списания которых превышает 12 месяцев после отчетной даты включается в строку «Прочие внеоборотные активы», а в части расходов, срок списания которых не превышает 12 месяцев в строку «Прочие оборотные активы».

Таким образом, на практике возникают определенные сложности и спорные ситуации при отражении в бухгалтерском учете указанных объектов. Необходимо устранить имеющиеся несоответствия в системе регулирования бухгалтерского учета в целях достижения единообразия в трактовках положений документов, регулирующих порядок ведения бухгалтерского учета. Для устранения вышеприведенных несоответствий необходимо принятие новых редакций обозначенных положений по бухгалтерскому учету и методических указаний, в которых были бы устранены все упоминания о расходах будущих периодов.

Если все-таки предполагается перенос расходов на будущие периоды, то необходимо на законодательном уровне закрепить условия, при которых объект может быть признан расходом будущих периодов. Например, аналогично тому, как в п.4 ПБУ 6/01 приведен перечень условий, при одновременном выполнении которых актив признается основным средством.

Следует отметить, что в МСФО термин «расходы будущих периодов» отсутствуют, поэтому российские организации, составляющие отчетность по международным стандартам, вынуждены решать проблему реклассификации расходов будущих периодов в расходы или в активы. Таким образом, наличие подобных учетных категорий в российском бухгалтерском учете не способствует дальнейшей интеграции отечественных бухгалтерских стандартов с МСФО. 


\section{ЛИТЕРАТУРА}

1. Положение по ведению бухгалтерского учета и бухгалтерской отчетности в Российской Федерации: приказ Минфина РФ от 29.07.1998 г. №34н (в ред. от 24.12.10 г., с изм. от 08.07.16 г.) // СПС КонсультантПлюс. - Москва, 2016.

2. Положение по бухгалтерскому учету «Учет нематериальных активов» (ПБУ 14/07): приказ Минфина РФ от 27.12.07 г. №167н: (в ред. от 16.05.16 г.) // СПС КонсультантПлюс. - Москва, 2016.

3. Положение по бухгалтерскому учету «Учет договоров строительного подряда» (ПБУ 2/08): приказ Минфина РФ от 24.10.08 г. №167н: (в ред. от 06.04.15 г.)// СПС КонсультантПлюс. - Москва, 2016.

4. Крутякова, Т.Л. Годовой отчет 2015. - Москва: АйСи Групп, 2015. -544 с. 


\title{
ОСОБЕННОСТИ ФОРМИРОВАНИЯ ПРОДАЖНЫХ ЦЕН НА ПРОДУКЦИЮ ОБЩЕСТВЕННОГО ПИТАНИЯ
}

Охезина К.Ю. студент, Кубанский государственный университет, г. Краснодар Погосян С.A. магистрант, Кубанский государственный университет, г. Краснодар Научный руководитель: Костюкова И.Н. к. э. н., доцент, Кубанский государственный университет, г. Краснодар

\begin{abstract}
Аннотация. В наши дни сфера общественного питания имеет чрезвычайно важное экономическое и социальное значение для общества в иелом. Для формирования цены на различных уровнях производства применяют разные методы и способы расчета наченки. В статье рассмотрены два основных метода формирования розничных иен в сфере общественного питания на основе наценок и себестоимости.

Ключевые слова: учет в общественном питании, продажная цеена, розничная цуена, калькулирование себестоимости продукиии общественного питания.
\end{abstract}

\section{FEATURES OF FOODSTUFF VALUATION}

Ohezina K.Yu. student, Kuban state university, Krasnodar

Pogosyan S.A. magistrant, Kuban state university, Krasnodar Research supervisor: Kostyukova I.N. cand. econ. sci., associate professor, Kuban state university, Krasnodar

\begin{abstract}
In our days, the foodservice industry is of crucial economic and social importance for society as a whole. For the formation of prices at different levels of production using different methods and ways of calculation of margin. The article discusses the two main methods of formation of retail prices in the sphere of public catering on the basis of margins and costs.

Key words: accounting in public catering, sales price, sales price, calculation of cost of production of public catering.
\end{abstract}

Организацией общественного питания признается организация, предназначенная для производства различной кулинарной продукции, разнообразных мучных изделий, их дальнейшей реализации и организации самого потребления.

В наши дни сфера общественного питания считается более развитой и популярной отраслью, чем другие. Также данная отрасль имеет чрезвычайно важное экономическое и социальное значение для общества в целом. Социальное значение сферы общественного питания и ее роль в современной рыночной экономике проявляется в облегчении и улучшении жизни людей, именно поэтому необходимо ка- чественное развитие и изменение организации общественного питания. В эту отрасль включают фабричные производства, услуги, предлагаемые в ресторанах и кафе. Для формирования цены на различных уровнях производства применяют разные методы и способы расчета наценки.

Существует два метода формирования розничных цен в сфере общественного производства на основе наценок и себестоимости.

Промышленный метод формирования цен в общественном производстве применяется редко из-за довольно сложного расчета трудовых затрат и распределения накладных расходов при приготовлении различных блюд и продукции. Чаще всего это происходит из-за 
проблемы дать правильную оценку стоимости работы персонала по производству продукции, а также определить наценку из-за эксклюзивности данного товара.

Формирование покупной цены на продукцию в сфере производства общественного питания чаще всего происходит путем прибавления торговой наценки к покупной стоимости. Наценка в сфере общественного производства зачастую выше, чем в торговле, вследствие того, что предприятия общественного питания, кроме расходов на продажу, несут также и дополнительные расходы.

Для учета сырья, товаров и продукции собственного производства в сфере ОП применяют счета: 20 «Основное производство»; 41 1 «Товары на складах»; 41-2 «Товары в розничной торговле»; 43 «Готовая продукция».

Расходы, связанные с самим производством и продажей готовой продукции и товаров, учитываются на счете 44 «Расходы на продажу».

Продажная цена продукции общественного питания состоит из следующих элементов: стоимости сырья, торговой наценки [8]. Торговая наценка, в свою очередь, складывается из запланированного дохода предприятия и налога на добавленную стоимость, если его нужно платить.

Расчет осуществляется с помощью процесса калькуляции на основании нормативов, установленных сборниками рецептур. Проводит расчеты бухгалтер-калькулятор.

Нормативными документами, которыми руководствуется бухгалтер, считаются сборники рецептур, которые используют в общественном производстве. Они содержат в себе данные, необходимые для расчета продажной цены, а именно: непосредственно сам расход сырья, необходимый для изготовления какоголибо блюда, также данный сборник устанавливает и обязательные для всех организаций общественного производства нормы выхода готовых изделий, вплоть до указания массы отдельных составляющих, а рекомендуемый общий вес готового блюда также указывается в граммах.

Перед составлением калькуляции нужно точно знать ассортимент всех изготавливаемых блюд, нормы каждого компонента, соответствующих сборникам рецептур, плюс ко всему необходимо знать точные продажные цены на сырье.

Составление калькуляционной карточки производится ответственным бухгалтером на основании:

а) блюд, предлагаемых организацией общепита в плане-меню;

б) норм сырья;

в) продажных цен сырья.

Рассчитывая, бухгалтер-калькулятор записывает данный расчет в калькуляционной карточке [3]. В организациях общественного питания на каждое предлагаемое блюдо существует отдельная калькуляционная карточка. При изменении цены на отдельный вид сырья, есть необходимость снова исчислять продажную цену блюда, все изменения также отражается в этой калькуляционной карточке, но единственное отличие, что изменения отражают в свободных графах.

Именно поэтому постоянно меняющиеся цены приносят трудности всем работникам заведения от официантов до бухгалтера [1]. Так как постоянное изменение цены не дает возможности указать единую в меню.

Иногда государство устанавливает предел, к примеру, на продукцию, которая в свою очередь реализуется в организациях общественного питания при общеобразовательных учреждениях, училищах, в средних и высших учебных заведениях [2]. Размер продажной цены в обязательном порядке определяют методом калькулирования.

При составлении калькуляционной карточки бухгалтер особое внимание уделяет графе 
«Выход в готовом виде»: там указывается вес в граммах на одно готовое блюдо. Все расходы сырья учитываются в бухгалтерии на основании документов, поступивших со склада и эти данные напрямую влияют на розничную цену готового блюда.

Чтобы работникам кухни или производства получить необходимое сырье для приготовления блюда они составляют требование. Требование составляют по надобности и только в одном экземпляре, далее заверяют подписью заведующего и утверждают подписью руководителя. Затем, на основании таких требований, в кладовую выписывается накладная на отпуск товара. Данная накладная составляется уже в двух экземплярах, один остается у материально-ответственного лица, а второй вместе с товарным отчетом сдается в бухгалтерию организации общественного производства.

\section{ЛИТЕРАТУРА}

$1 . О$ защите прав потребителей: Закон РФ от 07.02.92 г №2300-1 (в ред. от 03.07.16 г.) // СПС «КонсультантПлюс». - Москва, 2016.

2. О мерах по упорядочению государственного регулирования цен (тарифов): Постановление Правительства Российской Федерации от 07.03 .95 г. №239 (в ред. от 30.04 .16 г.) // СПС «КонсультантПлюс». - Москва, 2016.

3. Альбом унифицированных форм первичной учетной документации по учету операций в общественном питании: Постановление Госкомстата РФ от 25.12.98 г. № 132 // СПС «КонсультантПлюс». - Москва, 2016.

4. Antonova, N.A. Trade stocks: recognition and measurement / N.A. Antonova, I.N. Kostyukova, D.V. Lugovskoy // Научные труды SWorld, 2013. T. 32. №2. - P. 72-82.

5. Костюкова, И.Н. Признание и оценка товаров в соответствии с российскими и международными стандартами финансовой отчетности / И.Н. Костюкова, Д.В. Луговской // Международный бухгалтерский учет, 2011. №19. - С. 2-10.

6. Костюкова, И.Н. Особенности отражения в бухгалтерском учете переоценки товаров // Все для бухгалтера, 2008. № 8. - С. 26-28.

7. Костюкова, И.Н. Оценка и учет товаров в оптовой, розничной и мелкорозничной торговле. Учебное пособие / И.Н. Костюкова, Д.В. Луговской // - Краснодар: Просвещение-Юг, 2014. - 124 с.

8. Кузнецова, И.М. Определение продажных цен на продукцию собственного производства организациями общественного питания // Экономика, управление, финансы: материалы II междунар. науч. конф. - Пермь: Меркурий, 2012. - С. 83-89. 


\title{
СПЕЦИФИКА ОРГАНИЗАЦИИ И ВЕДЕНИЯ БУХГАЛТЕРСКОГО УЧЕТА НА ПРЕДПРИЯТИЯХ ПИЩЕВОЙ ПРОМЫШЛЕННОСТИ
}

Погосян С.A. магистрант, Кубанский государственный университет, г. Краснодар

Научный руководитель: Костюкова И.Н. к. э. н., доцент, Кубанский государственный университет, г. Краснодар

\begin{abstract}
Аннотация. В статье охарактеризованы основные особенности функционирования предприятий пищевой промышленности, определяющие специфику организации бухгалтерского учета в данном секторе экономики. Систематизированы задачи бухгалтерского учета на предприятиях пищевой промышленности. Особое внимание уделено раскрытию особенностей калькулирования себестоимости и оценки готовой продукции.

Ключевые слова: пищевая промышленность, учет на предприятиях пищевой промьиленности, готовая продукция, незавершенное производство, калькулирование себестоимости в пищевой промышленности.
\end{abstract}

\section{SECIFICS OF THE ORGANIZATION AND ACCOUNTING IN THE FOOD INDUSTRY}

Pogosyan S.A. magistrant, Kuban state university, Krasnodar Research supervisor: Kostyukova I.N. cand. econ. sci., associate professor, Kuban state university, Krasnodar

\begin{abstract}
The article describes the main features of the functioning of the food industry, determine the specificity of accounting in this sector of the economy. Systematic tasks of accounting at the enterprises of the food industry. Special attention is paid to the characteristics of cost calculation and evaluation of the finished product.

Key words: food industry, accounting at the enterprises of the food industry, finished products, work in process, costing in the food industry.
\end{abstract}

Пищевая промышленность - одна из ведущих отраслей экономики. Ее основное звено предприятие (организация). Задачи промышленного предприятия состоят в обеспечении потребностей рынка выпускаемыми продуктами питания, совершенствовании организации производства и на этой основе улучшения всех экономических показателей финансовохозяйственной деятельности.

Развитие отечественной пищевой промышленности на современном этапе характеризуется значительным ростом товарооборота, повышением качества и расширением ассортимента реализуемой продукции, усилением интеграции с другими отраслями экономики, расширением международной интеграции.
В зависимости от участия в изготовлении основной продукции и назначения все пищевые производства, как правило, делятся на основные, вспомогательные, побочные, подсобные и обслуживающие.

Основное производство нацелено на непосредственный выпуск продукции, выступающей предметом основной деятельности предприятия, или изготовлением для этой продукции полуфабрикатов (мясомолочные, сахарные, кондитерские, хлебопекарные и т. д.).

Вспомогательные производства непосредственно не участвуют в изготовлении основной продукции, но обслуживают его и все предприятие, оказывая услуги, работы, производя продукцию (ремонтно-механические, энергетические, инструментальные). 
Побочные производства заняты утилизацией отходов основного производства (к примеру, сухого жома при производстве сахара).

Подсобные производства производят продукцию не из основного материала, которая используется в основных и вспомогательных производствах (цехи, занятые изготовлением тары и упаковочных материалов для собственных нужд).

Кроме того, на предприятиях пищевой промышленности имеются непромышленные производства и хозяйства, которые обслуживают нужды трудового коллектива предприятия (жилищно-коммунальное хозяйство, содержание столовых, буфетов, детских дошкольных учреждений, санаториев и т. д.).

Учет затрат этих производств и хозяйств ведут на синтетических счетах 20, 23 и 29. По дебету этих счетов записывают остаток незавершенного производства на начало и конец месяца, затраты за месяц; по кредиту - фактическую себестоимость выпущенной продукции, работ и услуг, стоимость забракованной продукции и ценных отходов.

В процессе производства пищевая промышленность производит продукты питания, а также выполняют работы и услуги на сторону.

По степени готовности различают готовую продукцию (прошла все стадии производства, проверена техническим контролем и сдана на склад), незавершенное производство (продукция, не законченная производством) и полуфабрикаты (изделия, законченные производством в одном цехе, но требующие обработки в других цехах предприятия). Готовую продукцию в балансе оценивают по фактической или плановой (нормативной) себестоимости, для чего на предприятия х в соответствии с выбранной ими учетной политикой может применяться счет 40.
По дебету этого счета отражается фактическая производственная себестоимость выпущенной из производства продукции (в корреспонденции со счетами 20, 23, 29).

По кредиту отражается нормативная (плановая) себестоимость произведенной продукции (в корреспонденции со счетами 43, 90 и др.).

Сопоставлением дебетового и кредитового оборотов по счету 40 на последнее число месяца на предприятиях пищевой промышленности определяется отклонение фактической производственной себестоимости произведенной продукции, сданных работ и оказанных услуг от нормативной (плановой) себестоимости. Экономия, т. е. превышение нормативной (плановой) себестоимости над фактической, сторнируется по кредиту счета 40 и дебету счета 90. Перерасход, т. е. превышение фактической себестоимости над нормативно й (плановой), списывается со счета 40 в дебет счета 90 дополнительной записью.

Следующей особенностью формирования учетной политики на предприятиях пищевой промышленности выступает выбор способа оценки незавершенного производства. В качестве таковых для целей бухгалтерского финансового учета, как правило, используется оценка: по нормативной (плановой) производственной себестоимости; по прямым статьям расходов; по стоимости сырья, материалов, полуфабрикатов; по фактически произведенным затратам.

В целях налогообложения, для налогоплательщиков, производство которых связано с обработкой и переработкой сырья (что, как правило, и составляет основную деятельность предприятий пищевой промышленности), сумма прямых расходов распределяется на остатки незавершенного производства в доле, соответствующей доле таких остатков в исходном сырье (в количественном выражении), за минусом технологических потерь. 
К основным показателям, характеризующим деятельность предприятий пишевой промышленности, относят объем проданной продукции, прибыль и рентабельность. Организованный на предприятиях пищевой промышленности бухгалтерский учет должен отвечать требованиям рыночной экономики, нормативных общероссийских и отраслевых документов, а также учитывать особенности организации и технологии производства.

Перед бухгалтерским учетом в пищевой промышленности стоят следующие основные задачи:

- правильно и своевременно отражать и контролировать выполнение плана по всем показателям;

- контролировать соблюдение принципов бухгалтерского учета, обеспечение безубыточной работы, ликвидацию потерь в производстве и различного рода непроизводительных расходов;

- обеспечивать сохранность и экономное расходование материальных, трудовых и других ресурсов;

- правильно отражать затраты на производство, своевременно и точно калькулировать себестоимость продукции;

- обеспечивать руководство предприятия своевременной и достоверной информацие й, необходимой для оперативного руководства его работой;

- формировать объективную и достоверную финансовую отчетность.

Затраты предприятия на производство и продажу продукции в денежной форме составляют себестоимость продукции. Это издержки на потребленные средства производства, заработная плата с отчислениями на социальное страхование и обеспечение в форме единого социального налога, расходы по обслуживанию производства и др. Различают плановую и фактическую себестоимость продукции.
Плановую себестоимость определяют исходя из экономически обоснованных норм расхода материальных ресурсов, затрат труда и т. д.

Фактическая себестоимость характеризуется фактическими затратами, которые могут отклоняться от плановых по причинам, зависящим от особенностей конкретного предприятия пищевой промышленности (экономия или перерасход отдельных видов затрат и др.) и не зависящим от него (изменение цен на материалы, тарифов за электроэнергию и др.).

При планировании, учете и анализе затрат, которые образуют себестоимость продукции предприятий пищевой промышленности, применяют следующие группировки: «по месту возникновения затраты группируют по производствам, цехам, участкам; по видам продукции, работ и услуг; по видам расходов (статьям и элементам затрат)» [1].

В качестве типовой в пищевой промышленности «принята следующая группировка затрат по статьям:

- сырье и материалы;

- возвратные отходы (вычитаются);

- покупные изделия, полуфабрикаты и услуги производственного характера сторонних предприятий и организаций;

- топливо и энергия на технологические цели;

- основная заработная плата производственных рабочих;

- дополнительная заработная плата производственных рабочих;

- отчисления на социальное страхование и обеспечение;

- затраты на подготовку и освоение производства;

- затраты на содержание и эксплуатацию оборудования;

- общепроизводственные расходы;

- общехозяйственные расходы;

- потери от брака; 
- прочие производственные расходы;

- внепроизводственные расходы» [1].

Затраты на производство группируют в учете по следующим экономическим элементам: сырье и основные материалы (за вычетом возвратных отходов), покупные изделия и полуфабрикаты, работы и услуги производственного характера, вспомогательные материалы, топливо, энергия, заработная плата основная и дополнительная, отчисления на социальное страхование, амортизация основных средств и нематериальных активов, прочие расходы.
Таким образом, бухгалтерский учет в пищевой промышленности имеет свои особенности, обусловленные технологией производственного процесса, наличием широкого спектра вспомогательных, подсобных и обслуживающих структурных подразделений, что проявляется в возможности выбора тех или иных составляющих учетной политики, позволяющих максимально полно и адекватно отразить специфику хозяйственной деятельности.

\section{ЛИТЕРАТУРА}

1. Дейнекин, В.Н. Организация учетной политики на предприятиях по переработке зерна: диссертация ... кандидата экономических наук: 08.00.12.- Орел, 2004.- 257 c.

2. Мазлова, Л.И. Обеспечение материальной заинтересованности рабочих в результатах труда / Л.И. Мазлова, И.Н. Костюкова // Известия высших учебных заведений. Пищевая технология, 1991. №1-3. - С. 15-17. 


\title{
АНАЛИЗ НОРМАТИВНО-ПРАВОВОЙ БАЗЫ ПО УЧЕТУ РЕЗЕРВОВ
}

Путренко А.В. магистрант, Адыгейский государственный университет, г. Майкоп

Ордынская M.E. канд. экон. наук, доцент Адыгейский государственнылй университет, г. Майкоп

\begin{abstract}
Аннотация B статье проанализирована действующая нормативно-правовая база, регулирующая вопросы формирования и использования резервов в организациях. Актуальность этого вопроса связана с частыми изменениями, вносимыми в нормативные документы, существенным отличием бухгалтерского и налогового учета в части создания и использования резервов.

Ключевые слова: бухгалтерский учет, налоговый учет, резерв, резервный капитал, оценочные резервы, резервы предстоящих расходов.
\end{abstract}

ANAL YSIS OF THE LEGAL FRAMEWORK FOR ACCOUNTING RESERVES

Putrenko A.V. undergraduate, Adyghe State University, Maikop

Ordynskaya M.E. Cand. Econ.Sci., associate professor, Adygei state university, Maikop

\begin{abstract}
The article analyzes the existing legal framework, regulating the issues of formation and use of reserves in organizations. The relevance of this issue is related to the frequent changes made to the regulations, a significant difference between the accounting and tax accounting in terms of the creation and use of reserves.
\end{abstract}

Key words: business accounting, tax accounting, reserve, capital reserves, valuation reserves, reserves for future expenses.

Термин «резерв» достаточно часто встречается в научной и специальной экономической литературе. Происходит он либо от французского «reserve», т.е. запас, либо от латинского «reservo», т.е. сберегаю, сохраняю. [3, с. 290]

Следует иметь в виду, что данный термин применяется в двух смыслах. Во-первых, под резервами понимаются запасы ресурсов, необходимые для бесперебойной работы организации, создаваемые целенаправленно на случай дополнительной потребности в них. Во-вторых, под резервами зачастую имеют ввиду неиспользованные возможности повышения эффективности производства. Это так называемые экономические резервы.

Таким образом, понятие резерва двойственно: с одной стороны, это запасы, а с другой стороны - потенциальные возможности использования.
Определение резервов дают многие экономисты-бухгалтеры, затрагивая разные аспекты этой проблемы и рассматривая резервы именно как особый объект бухгалтерского учета.

Проанализируем определения резервов, которые были сформулированы различными авторами.

В большом бухгалтерском словаре под ред. А.Н. Азриляна дано следующее определение резервов: «это обособленная часть активов, которая конщентрируется в резервных (страховых) фондах и предназначается для покрытия непредвиденных потребностей, расходов для подстраховки рисков» [1, с. 395].

Соколов Я.В. определяет резервы как накопления для покрытия ожидаемых и строго определенных расходов организации [12, с. 288]. 
Бабаев Ю.А. отмечает, что «резервы создаются для уточнения оценки отдельных статей бухгалтерского учета и покрытия предстоящих расходов и платежей〉 [2, с. 141]

Итак, в основе понятия «резерв» находятся такие отношения, которые возникают в связи со страхованием рисков, связанных с финансово-хозяйственной деятельностью, а также отражением факторов и результатов этой деятельности в учете. Следует понимать, что резервы не выражаются запасом денежных средств или иных ценностей в натуральном или стоимостном измерителе, а резервируют финансовый результат и одновременно уточняют оценку учетных объектов [5, с. 63].

В настоящее время разрешено формирование резервного капитала, оценочных резервов и резервов предстоящих расходов [4, с. 158].

Резервный капитал призван обеспечивать интересы собственников организации, создается для покрытия убытков организации, погашения облигаций и выкупа собственных акций посредством отчислений из чистой прибыли. Его учет осуществляется на счете 82 «Резервный капитал».

Оценочные резервы, представляют собой корректировки балансовой стоимости активов или обязательств из-за появления новой информации. В отечественных стандартах учету оценочных резервов уделяется довольно много внимания, для них в Плане счетов выделены отдельные счета. В п. 3 ПБУ 21/2008 названы элементы оценочных резервов. Итак, к оценочным резервам относятся: резерв по сомнительным долгам (счет 63 «Резервы по сомнительным долгам»); резерв под обесценение финансовых вложений (счет 59 «Резервы под обесценение финансовых вложений»); резерв под снижение стоимости материальных ценностей (счет 14 «Резервы под снижение стоимости материальных ценностей»).

Резерв по снижение стоимости материальных ценностей регламентирован п. 25 ПБУ 5/01.
Создание резерва под обесценение финансовых вложений регламентируется п. 38 ПБУ 19/02. Формирование резерва по сомнительным долгам осуществляется в соответствии с п. 70 Положения №34н. Все они создаются за счет финансовых результатов

Резервы предстоящих затрат создаются посредством начисления производственных затрат равными частями равномерно в течение отчетного периода на основе плановых величин. Для их учета используется счет 96 «езервы предстоящих расходов», по которому можно создавать следующие виды резервов: резерв предстоящей оплаты отпусков работникам организации; резерв на выплату ежегодного вознаграждения за выслугу лет; резерв производственных затрат по подготовительным работам в связи с сезонным характером производства; резерв на ремонт основных средств; резерв предстоящих затрат на рекультивацию земель и осуществление иных природоохранных мероприятий; резерв на гарантийный ремонт и гарантийное обслуживание [6, c.170].

Итак, обобщим в виде таблицы отечественную систему нормативно-правового регулирования резервов.

Изначально, в ПБУ 8/01 «Условные факты хозяйственной деятельности» говорилось, что все существенные последствия условных фактов должны быть отражены в бухгалтерской отчетности. В том варианте ПБУ резерв не выделялся как отдельный вид обязательства, хотя и было указано, что он создаётся в связи с существующими на отчётную дату условными обязательствами.

Условные обязательства связаны с возможностью уменьшения экономических выгод организации в будущем, а рассматриваемый резерв подразумевает накопление средств за счет финансовых итогов деятельности для покрытия определенных потерь. 


\section{Таблица 1-Система нормативно-правового регулирования резервов в РФ}

\begin{tabular}{|l|l|}
\hline \multicolumn{1}{|c|}{$\begin{array}{c}\text { Элемент системы } \\
\text { резервирования }\end{array}$} & \multicolumn{1}{|c|}{ Нормативно-правовой акт } \\
\hline Резервный капитал & $\begin{array}{l}\text { Положение по ведению бухгалтерского учета и бухгалтерской } \\
\text { отчетности в Российской Федерации [11] }\end{array}$ \\
\hline Оценочные резервы & $\begin{array}{l}\text { ПБУ 21/08 «Изменения оценочных значений» [10] } \\
\text { ПБУ 5/01 «Учет МПЗ» [7] } \\
\text { ПБУ 19/02 «Учет финансовых вложений» [9] } \\
\text { Положение по ведению бухгалтерского учета и бухгалтерской } \\
\text { отчетности в Российской Федерации [11] }\end{array}$ \\
\hline $\begin{array}{l}\text { Оценочные } \\
\text { обязательства }\end{array}$ & $\begin{array}{l}\text { ПБУ 8//2010 «Оценочные обязательства, условные обязательства и } \\
\text { условные активы» [8] }\end{array}$ \\
\hline
\end{tabular}

2010 г. связан с существенными изменениями, которые были внесены нормативно-правовую базу в части учета резервов. Новое ПБУ 8/2010 не предусматривает создание каких-либо резервов под условные обязательства [8].

Серьезные изменения произошли в учете резервов предстоящих расходов. Это было связано с отменой п. 72 Положения №34н, который содержал перечень резервов предстоящих расходов и давал право создавать резервы этой группы. В положениях и методических указаниях по бухгалтерскому учету упоминаний об этих резервах нет. Однако, в План счетов и Инструкцию по его применению соответствующие изменения внесены не были.

На счете 96 в соответствии ПБУ 8/2010 отражаются оценочные обязательства организации. Но оценочные обязательства и резервы предстоящих затрат различаются по своему назначению. В основе формирования оценочных обязательств лежит оценка ожидаемой суммы кредиторской задолженности, право на получение которой имеется вследствие свершившихся действий или событий. В отличие от предстоящих расходов, при начислении оценочных обязательств обеспечение точности расчета соответствующих величин превалирует над принципом равномерности распределения планируемых затрат. Помимо этого, период начисления оценочных обязательств связан с моментом возникновения прав на получение соответствующих сумм в будущем и может не соответствовать календарному году. Следовательно, эти учетные категории представляют собой совершенно разные группы резервов. Например, оценочное обязательство по оплате отпусков и резерв по предстоящей оплате отпусков - это два разных объекта учета.

В конечном счете, создание резервов в бухгалтерском учете призвано повысить достоверность информации, представляемой в бухгалтерской финансовой отчетности [6, с. 170].

Создание резервом для налогового учета регламентируется Налоговым кодексом. При этом могут быть созданы: резервы по сомнительным долгам (ст. 266 НК РФ); резервы по гарантийному ремонту и гарантийному обслуживанию (ст. 267 НК РФ); резервы по обеспечению социальной защиты инвалидов (ст. 267.1 НК РФ); резервы на научные исследования и опытно-конструкторские разработки - НИОКР (ст. 267.2 НК РФ); резервы предстоящих расходов некоммерческих организаций (ст. 267.3 НК РФ); резервы предстоящих расходов, связанных с завершением деятельности по добыче углеводородного сырья на новом морском месторождении углеводородного сырья (ст. 267.4 НК РФ); резервы предстоящих расходов на оплату отпусков и ежегодного вознаграждения за выслугу лет (ст. 324.1 НК РФ) [6, с.170]. 
Из вышесказанного можно сделать вывод о том, что только три резерва создаются и в бухгалтерском, и в налоговом учете. Это резерв по сомнительным долгам, по гарантийному ремонту и обслуживанию, на предстоящую оплату отпусков

Следует отметить тот факт, что в учетной практике российских предприятий резервы создаются крайне редко вследствие того, что создание резервов требует от бухгалтера специальных профессиональных компетенций и повышает трудоемкость учетного процесса.
Формируются, в основном, только обязательные резервы (под обесценение финансовых вложений, по сомнительным долгам). К числу потенциально обязательных резервов можно отнести резервы на предстоящие расходы на оплату отпусков, выплату ежегодного вознаграждения за выслугу лет. Так, с 01.01.2013 г. в России планировалось введение нового учетного стандарта - ПБУ «Учет вознаграждений работникам», аналога МСФО (IAS) 19 «Вознаграждения работникам». Однако это пока так и осталось проектом.

\section{ЛИТЕРАТУРА}

1. Азрилян, А.Н. Большой бухгалтерский словарь. - М.: Институт новой экономики, 1999 - 574 c.

2. Бабаева, Ю.А. Бухгалтерский учет: учебник для вузов. - М.: ЮНИТИ-ДАНА, 2002. $-476 \mathrm{c}$.

3. Левкутная, Т.В. Резервы как объект бухгалтерского учета / Т.В. Левкутная, А.Е. Шевелев // Современные проблемы науки и образования, 2012 . №3 - С. 290.

4. Мизиковский, И.Ф. Концепция объективизации резервов в бухгалтерском учете / И.Ф. Мизиковский, Е.П. Поликарпова // Синергия учета, анализа и аудита в обеспечении экономической безопасности бизнеса и государства: сборник материалов II международной межвузовской научно-практической конференции, посвященной памяти проф. Петровой В.И. и проф. Баканова М.И. - 2016. - С.158-165.

5. Ордынская, М.Е. Методология учета оценочных резервов и оценочных обязательств / М.Е. Ордынская, Т.А. Силина, С.В. Карпенко // Научные труды SWorld. Выпуск 1(42). Том 8. Иваново: Научный мир, 2016 - С.63-72.

6. Ордынская, М.Е. Сравнительный анализ налогового и бухгалтерского учета резервов организаций в РФ / М.Е. Ордынская, Т.А. Силина, С.В. Карпенко // Научный взгляд в будущее. Выпуск 1(1). Том 5. - Одесса: КУПРИЕНКО С.В., 2016 - С.168174.

7. Положение по бухгалтерскому учету «Учет материально-производственных запасов» (ПБУ 5/01): Приказ Минфина РФ от 09.06.2001 г. №44н. (ред. от 16.05.2016 г.) // СПС «Консультант Плюс». - Москва, 2016.

8. Положение по бухгалтерскому учету «Оценочные обязательства, условные обязательства и условные активы» (ПБУ 8/2010): приказ Минфина РФ от 13.12.2010 г. №167н (ред. от 06.04.2015 г.) // СПС «Консультант Плюс». - Москва, 2016.

9. Положение по бухгалтерскому учету «Учет финансовых вложений» (ПБУ 19/02): приказ Минфина РФ от 10.12.2002 г. №126н. (ред. от 06.04.2015 г.) // СПС «Консультант Плюс». - Москва, 2016.

10. Положение по бухгалтерскому учету «Изменения оценочных значений» (ПБУ 21/08) : приказ Минфина РФ от 06.10.2008 г. №106н. (ред. от 06.04.2015 г.) // СПС «Консультант Плюс». - Москва, 2016. 
11. Положение по ведению бухгалтерского учета и бухгалтерской отчетности в Российской Федерации: приказ Минфина РФ от 29.07.1998 г. №34н. (ред. от 24.12.2010 г., с изм. от 08.07.2016 г.) // СПС «КонсультантПлюс». - Москва, 2016.

12. Соколов, Я.В. Основы теории бухгалтерского учета. - М.: Финансы и статистика, $2000-496$ c. 


\title{
ОСОБЕННОСТИ УЧЕТА ОПЕРАЦИЙ С ФИНАНСОВЫМИ ИНСТРУМЕНТАМИ
}

Самохвалова А.В.

Магистр, Кубанский государственный университет, г. Краснодар

Научный руководитель: Рябченко А. В.

к.э.н., доцент, Кубанский государственный университет, г. Краснодар

\begin{abstract}
Аннотация: В условиях мирового финансового кризиса вопросы понятия, классификащии и оценки финансовых инструментов становятся все более актуальными как для структур, регулирующих учет финансовых инструментов в международном масштабе, так и бухгалтерам, аудиторам и пользователям бухгалтерской отчетности.

Ключевые слова: Финансовые инструменты, акиии, деривативы, отчет о прибылях и убытках, финансовая отчетность, облигачии.
\end{abstract}

\section{FEATURES OF ACCOUNTING TRANSACTIONS WITH FINANCIAL INSTRUMENTS}

Samohvalova A.V.

Magistr, Kuban State University, Krasnodar Research supervisor: Ryabchenko A. V.

Cand.Econ.Sci., associate professor, Kuban State University, Krasnodar

\begin{abstract}
Amid the global financial crisis, questions the concepts of classification and measurement of financial instruments are becoming increasingly important for institutions that govern the accounting for financial instruments at the international level, as well as accountants, auditors and users of financial statements.

Keywords: Financial instruments, shares, derivatives, income statement, financial statements, bonds.
\end{abstract}

Рассмотрим определение финансового инструмента, который обозначает, что финансовый инструмент является договором, дающим начало финансовому активу одного предприя тия и финансовой ответственности или долевого инструмента другого предприятия [1].

Со ссылками на активы, обязательства и долевые инструменты, финансовые инструменты бывают отраженными (признанными) «на балансе» организации, и не отраженным и «на ее балансе». Финансовый актив или финансовое обязательство признается организацией в отчете о финансовом положении, если становятся стороной договорных положений финансового инструмента.

Например, когда счет выставлен на продажу товаров в кредит, предприятие, продавшее товары, имеет финансовый актив - дебиторскую задолженность - в то время как покупатель должен объяснить финансовую ответственность - кредиторская задолженность. Или когда предприятие увеличивает финансирование, выпуская обыкновенные акции. Или предприятие, покупающее акции, имеет финансовый актив - инвестиции - в то время как эмитент акций, увеличивший финансиров ание, должен учитывать долевой инструмент обыкновенный акционерный капитал. Или когда предприятие увеличивает финансирование, выпуская облигации (долговые обязательства). Предприятие, покупающее облигации - т.е. предоставляющее деньги - имеет финансовый актив - инвестиции - в то время как эмитент облигаций - т.е. заемщик, увеличивший финансирование - должен учитывать облигации как финансовую ответственность. Таким образом, когда речь идет об учете финансовых инструментов, - то это и инвести- 
ции в акции, инвестиции в облигации и дебиторскую задолженность (финансовые активы), и торговые кредиторские задолженности и долгосрочные кредиты (финансовые обязательства) и обыкновенный акционерный капитал (долевые инструменты), также к финансовым инструментам относятся деривативы.

В отношении того, как объяснить понятие финансовые инструменты, существуют различные проблемы вокруг их классификации.

В статье изучен учет долевых инструментов и финансовых обязательств. Когда предприятие увеличивает финансирование, то оно получает наличные средства взамен выпуска финансового инструмента.

Для предприятия, привлекающего финансирование, важно, чтобы инструмент был правильно классифицирован или как финансовая ответственность (долг) или как долевой инструмент (акции). Это различие важно, так как оно будет непосредственно влиять на решение пользователей которые используют финансовые отчеты для оценки финансового риска предприятия. Различие также повлияет на величину прибыли, поскольку финансовые затраты, связанные с финансовыми обязательствами, будут учитываться в отчете о финансовых результатах, таким образом уменьшая прибыль, в то время как дивиденды, выплаченные на обыкновенных акциях, являются увеличением прибыли, а не расходом.

При увеличении финансирования, выпущенный инструмент будет финансовой ответственностью, в противоположность тому, чтобы если это долевой инструмент, то возникает обязательство его возместить. Таким образом выпуск облигации (долговое обязательство) допускает возникновение финансовой ответственности, поскольку полученные суммы денег должны будут быть возмещены, в то время как выпуск обыкновенных акций создаст долевой инструмент.

Иногда возникает ситуация, когда финансовый инструмент выпущен, и содержит и элементы долга и собственного капитала. Примером этого является конвертируемая облигация - т.е. где облигация содержит вложенный дериватив в форме выбора преобразовать в акции, а не быть возмещенной наличными.

Долевые инструменты первоначально измеряются в справедливой стоимости.

Стоимость долевых инструментов повторно не изменяется. Любое изменение в справедливой стоимости акций не будет признано предприятием, поскольку прибыль или убыток рассчитан инвестором, владельцем акций. Дивиденды собственного капитала выплачив аются на усмотрение предприятия и составляются как сокращение нераспределенной прибыли, следовательно нет никакого изменения в балансовой стоимости долевых инструментов.

Если бы выпущенные акции были погашены, то в этом случае акции классифицировались как финансовые обязательства (долг), поскольку эмитент был бы обязан возместить суммы денег в будущем.

\section{ЛИТЕРАТУРА}

1. Международный стандарт финансовой отчетности (IAS) 39 «Финансовые инструменты: признание и оценка»: приказ Минфина РФ от 28.12.2015 г. № 217н (в ред. от 27.06 .16 г.) // СПС КонсультантПлюс. - Москва, 2016.

2. Аристова, К.О. Особенности влияния МСФО (IFRS) 15 на действующую модель признания выручки / К.О. Аристова, Е.В. Шматова // В сборнике: Экономика: Актуальные проблемы исследований на современном этапе: Материалы международной научно-практической конференции, 2016. - С. 39-45. 
3. Кутер, М.И. Теория многообразия балансов / М.И. Кутер, М.М. Гурская // Бухгалтерский учет, №48, 2003. №6. - С. 60-61.

4. Пономарева, Н.В. Особенности учета иностранной валюты в соответствии с МСФО // В сборнике: Стратегия развития учетно-аналитических и контрольных систем в механизме управления современными бизнес-процессами коммерческих организаций международный экономический форум «Бакановские чтения». - Орел, 2014. C. 90-93. 


\title{
К ВОПРОСУ УЧЕТА ЗАТРАТ НА ПРОИЗВОДСТВО ПРОДУКЦИИ ОБЩЕСТВЕННОГО ПИТАНИЯ
}

Сидорук Ю.В. студент, Кубанский государственный университет, г. Краснодар Погосян С.A. магистрант, Кубанский государственный университет, г. Краснодар Научный руководитель: Костюкова И.Н. к. э. н., доцент, Кубанский государственный университет, г. Краснодар

\begin{abstract}
Аннотация. Общественное питание - одна из наиболее сложных и значимых сфер обслуживания российской экономики. Главной особенностью бухгалтерского учета в общественном питании выступает одновременное использование счетов 20 «Основное производство» и 44 «Расходы на продажу». Рассматривается вопрос о правомерности отнесения затрат на оказание услуг общественного питания к незавершенному производству, проводится анализ положений МСФО и ПБУ.

Ключевые слова: бухгалтерский учет в общественном питании, учет готовой продукции, учет затрат на производство продукиии, незавершенное производство.
\end{abstract}

\section{THE QUESTION OF ACCOUNTING OF FOODSTUFF PRODUCTION EXPENSES}

Sidoruk Yu.V. student, Kuban state university, Krasnodar

Pogosyan S.A. magistrant, Kuban state university, Krasnodar

Research supervisor: Kostyukova I.N. cand. econ. sci., associate professor, Kuban state university, Krasnodar

\begin{abstract}
Catering is one of the most complex and important industries of the Russian economy. The main feature of accounting in public catering supports simultaneous use of accounts 20 "Basic production" and 44 "selling Expenses". Discusses the question of the legality of allocation of costs for the provision of catering services to work in progress, the analysis of IFRS and GAAP.

Key words: accounting in public catering, accounting of finished products, cost accounting for production, work in progress.
\end{abstract}

В настоящее время общественное питание одна из наиболее сложных и значимых сфер обслуживания российской экономики. Предприятия общественного питания выполняют важную роль в нашей повседневной жизни.

Наверное, не существует человека, который хотя бы раз в жизни не пользовался услугами общественного питания. Огромный спектр подобных заведений позволяет подобрать место, где можно перекусить быстро (кафе, уличные нестационарные закусочные и др.) или «со вкусом» посидеть. Можно пообедать недорого (комплексный ланч) или, заплатив большую сумму, в ресторане.
Как известно, услуги общественного питания признаются одним из видов предпринимательской деятельности, связанной с удовлетворением потребностей потребителей в питании и проведении досуга. Следует заметить, что организациям и индивидуальным предпринимателям, занимающимся подобным видом деятельности, никак не обойтись без надлежащего оперативного и бухгалтерского учета.

Порядок учета затрат на производство не совсем традиционен. Главной особенностью бухгалтерского учета в общественном питании выступает использование счета 20 «Ocновное производство» для калькулирования 
затрат производства и счета 44 «Расходы на продажу» - для издержек обращения.

Счет 20 «Основное производство» предназначен для обобщения информации о затратах основного производства на предприятиях общественного питания. На нем собирается информация о величине осуществленных затрат на производство готовых блюд, кулинарных изделий и напитков в разрезе стоимости сырья, необходимого для изготовления той или иной продукции. По дебету данного счета отражается стоимость сырья, поступившего в производство, то есть то сырье, которое передано в производство (кухню), а по кредиту стоимость сырья, израсходованного при приготовлении блюд, стоимость возвращенного сырья с кухни на склад, а также списание недостач и потерь продуктов.

Таким образом, по дебету счета 20 «Основное производство» можно увидеть только прямые затраты, связанные напрямую с выпуско м кулинарных изделий, выполнением работ и оказанием услуг, а по кредиту - суммы фактической себестоимости завершенных производством блюд. Остаток по счету на конец месяца показывает стоимость незавершенного производства, то есть стоимость блюд, не прошедших всех стадий технологической обработки.

В связи с тем, что предприятия общественного питания - это не производственные организации, а организации, оказывающие услуги населению, то возникает вопрос: можно ли отнести затраты по оказанию услуг к незавершенному производству.

В п. 63 Положения по ведению бухгалтерского учета и бухгалтерской отчетности в Российской Федерации сказано, что продукция (работы), не прошедшая всех стадий (фаз, переделов), предусмотренных технологическим процессом, а также изделия неукомплектованные, не прошедшие испытания и технической приемки, относят к незавершенному производству [1].

Как видим, указания на то, что услуга на определенной стадии может считаться незавершенным производством, российский нормативный правовой акт по бухгалтерскому учету не содержит. Зато такая оговорка представлена в п. 37 МСФО (IAS) 2 «Запасы»: «запасы поставщика услуг могут учитываться как незавершенное производство» [2]. Причем данные запасы включают в себя затраты на оказание услуг, в отношении которых предприятие еще не признало соответствующую выручку.

Остальные затраты, которые возникают в процессе деятельности организации по оказанию услуг общепита, отражаются на счете 44 «Расходы на продажу» и списываются с этого счета на увеличение расходов.

Счет 44 «Расходы на продажу» предназначе н для обобщения информации о расходах, связанных с продажей продукции, товаров, работ и услуг. По дебету данного счета собираются все производственные затраты, то есть отражаются данные о фактических издержках за отчетный месяц. Дебетовые суммы издержек обращения в части транспортных расходов распределяются между остатком непроданных и проданных на конец отчетного периода изделий собственного производства, а в конце отчетного периода частично или полностью списываются в дебет счета 90 «Продажи». При частичном списании издержек обращения возникает необходимость ежемесячно производить расчет. Особенностью данного расчета выступает то, что на него относятся только транспортные услуги, оказанные сторонними организациями. Затраты, произведенные собственными силами, в расчете не учитываются. Для удобства калькуляция издержек обращения на остаток изделий собственного производства обычно производят в специально разработанной для этих целей 
таблице. Предприятие общественного питания самостоятельно может выбрать метод списания расходов на продажу, закрепив его в своей учетной политике.

Следовательно, для расчета себестоимости готовых изделий к стоимости затраченных продуктов добавляют сумму издержек обращения в части транспортных расходов, относящихся к проданным блюдам. Полученную себестоимость доводят до продажной цены путем соответствующей наценки.

Предприятия общественного питания ежемесячно сопоставляют произведенные расходы с полученными доходами и выявляют результат своей деятельности. При этом в сравнении участвуют не все произведенные расходы, а только та их часть, которая относится к проданным изделиям собственного производства. Необходимость такого разграничения обусловлена следующим: товарноматериальные ценности должны показываться в бухгалтерском балансе торговой организации по их фактической стоимости, которая представляет собой сумму фактических затрат на их приобретение. Данные расходы отражаются при оприходовании сырья и товаров на счете 41 «Товары» в составе их закупочной стоимости. В то же время согласно ПБУ 5/01 «Учет материально-производственных запасов» затраты по заготовке и доставке товаров в торговой организации могут быть включены в состав издержек обращения и отражаться на счете 44 «Расходы на продажу».

Ежедневно, накануне дня приготовления пищи, заведующий производством составляет план-меню, в котором указываются наименования блюд, а также их номера согласно сборнику рецептур и технологической карточке, а также количество блюд, намечаемых к выпуску на следующий день.
План-меню составляется в одном экземпляре, подписывается заведующим производством и утверждается руководителем предприятия.

Заведующий производством составляет требование на продукты. Требование комплектуется с учетом потребности кухни в сырье (продуктах) на предстоящий день и остатков продуктов на начало текущего дня. Данное требование утверждается руководителем предприятия и служит основанием для выписки накладной на отпуск сырья (продуктов) со склада.

Дополнительный отпуск продуктов из склада на производство (кухню) в течение дня может происходить только по дополнительному требованию.

Поступающие на кухню продукты передаются под отчет заведующему производством. Поступление сырья из склада на кухню оформляется накладной. В кладовой сырье может отражаться по покупной или по продажной стоимости. Следует отметить, что учет сырья в ценах приобретения без добавления торговой наценки следует вести в кладовых предприятий, имеющих в подчинении различные типы (ресторан, кафе, бар, столовая, закусочная, магазин-кулинария и т.д.) и классы (рестораны и бары подразделяются на три класса: люкс, высший и первый).

Но несмотря на выбранный способ учета сырья на складе, на кухне продукты учитываются уже по продажным ценам, то есть по ценам приобретения с добавлением торговой наценки.

Таким образом, отрасль общественного питания имеет сложную технологическую цепочку, требующую тщательного учета сырья и готовых кулинарных изделий, поступающих и отпускаемых со склада, и постоянного контроля за правильностью ведения их учета. 
Учет затрат, включаемых в издержки обращения и производства предприятий общественного питания, должен помочь обеспечить своевременное, полное и достоверное отражение фактических расходов, а также контроль за использованием материальных, трудовых и финансовых ресурсов.

\section{ЛИТЕРАТУРА}

1. О введении международных стандартов финансовой отчетности и разъяснений международных стандартов финансовой отчетности на территории Российской Федерации и о признании утратившими силу некоторых приказов (отдельных положений приказов) Министерства финансов Российской Федерации: Приказ Минфина РФ от 28.12.15 г. №217н // СПС КонсультантПлюс. - Москва, 2016.

2. Положение по ведению бухгалтерского учета и бухгалтерской отчетности в РФ: Приказ Минфина РФ №34н от 29.07.98 г. (в ред. от 24.12.10 г.) // СПС КонсультантПлюс. - Москва, 2016.

3. Костюкова, И.Н. Идентификация и оценка запасов в соответствии с российскими и международными стандартами / И.Н. Костюкова, Д.В. Луговский, Р.А. Тхагапсо // Вестник Адыгейского государственного университета. - Серия 5: Экономика, 2014. № 3 (150). - C. 206-216.

4. Костюкова, И.Н. Понятие, виды и особенности учета тары и тарных материалов в торговых организациях / И.Н. Костюкова, Д.В. Луговский // Учет. Анализ. Аудит. 2016. № 5. - C. 106-121.

5. Силина, Т.А. Выбор метода оценки материалов как способ налоговой оптимизации в условиях инфляции / Силина Т.А., Андрюхина Д.В. // В сборнике: Наука. Образование. Молодежь Материалы XIII Международной научной конференции молодых ученых и аспирантов, 2016. - С 397-400

6. Ордынская, М.Е. Управление затратами на предприятии: учеб. пособие. - Майкоп: ЭлИТ, $2016 .-128$ с. 


\title{
БУХГАЛТЕРСКИЙ УЧЕТ ОСНОВНЫХ СРЕДСТВ В ГОСТИНИЧНО- РЕСТОРАННОМ БИЗНЕСЕ
}

Стакозов А.B. студент, Кубанский государственный университет, г. Краснодар Научный руководитель: Костюкова И.Н. к. э. н., доцент, Кубанский государственный университет, г. Краснодар

\begin{abstract}
Аннотация. В статье раскрыта специффика бухгалтерского учета основных средств в гостинично-ресторанном бизнесе и туризме. Описаны методы начисления амортизации, специфика проведения ремонтных работ. Перечислены виды основных средств, используемые в данной сфере, проанализированы положения основных нормативных документов, регулирующих бухгалтерский учет основных средств гостинищах и ресторанах.

Ключевые слова: гостиничный бизнес, ресторанный бизнес, основные средства, ремонт основных средств, учет основных средств, амортизация.
\end{abstract}

\section{PROPERTY ACCOUNTING IN HOTEL-RESTAURANT BUSINESS}

Stakozov A.V. student, Kuban state university, Krasnodar Research supervisor: Kostyukova I.N. cand. econ. sci., associate professor, Kuban state university, Krasnodar

\begin{abstract}
The article reveals the specifics of accounting of fixed assets in hotel and restaurant business and tourism. Described methods of depreciation, the specifics of the renovations. Lists the main tools used in this field, examined the provisions of the main normative documents regulating the accounting of fixed assets in hotels and restaurants.

Key words: hotel business, restaurant business, fixed assets repair of fixed assets, asset accounting, depreciation.
\end{abstract}

Гостинично-ресторанный бизнес активно развивается. Чем большее развитие получает отрасль, тем более сложным и ответственным в ней становится бухгалтерский учет. Бухгалтерский учет основных средств - одно из важнейших направлений деятельности любого предприятия. Данное направление всегда актуально. Получение достоверной информации об имуществе гостиниц и ресторанов обретает первостепенную роль именно сейчас, на этапе развития рыночных отношений. Искаженное представление информации об основных средствах в бухгалтерской отчетности приведет к ошибочному мнению о финансовом состоянии гостиницы и как следствие к принятию неверного решения пользователем данной отчетности. Учет основных средств один из трудоемких и ответственных участков работы бухгалтера и требует от него как творческих способностей, так и определенное количество знаний для оптимизации учета, вследствие этого часто совершаются ошибки именно в этом направлении. Именно поэтому и необходимо выявлять слабые участки бухгалтерского учета основных средств в гостинично-ресторанном бизнесе, совершенствовать данный процесс, а также оптимизировать порядок ведения учета в соответствии с законодательством РФ.

Исходя из норм, указанных в ПБУ 6/01 «Учет основных средств», основными средствами в ресторанно-гостиничном бизнесе и туризме, как правило, выступают:

1) транспортные средства; 
2) здания ресторанов, кафе, гостиниц, санаториев, турфирм, складов, прачечных, котельных;

3) трубопроводы, телефонные и электрические сети, теплотрассы;

4) мебель и хозяйственный инвентарь.

Часто в наличии имеются следующие виды объектов основных средств: спортивные площадки, многолетние насаждения, скульптуры, фонтаны, канализационные сооружения, артезианские скважины, сооружения водонасосных станций, трансформаторы, холодильные шкафы, печи, посудомоечные машины и др.

Руководство гостинищ, ресторанов и турфирм само определяет виды ремонта, модернизации, реконструкции в границах системы планово-предупредительных работ. Ремонтно-восстановительные работы бывают текущими и капитальными. Текущим ремонтом признаются работы, направленные на поддержание основных средств в рабочем состоянии. К нему можно отнести ремонт кровли, окон, оборудования, мебели, покраску стен и так далее. Капитальный ремонт подразумевает масштабные работы по смене устаревших конструкций, несущих стен, перепланировку, массовую модернизацию оборудования. При осуществлении ремонтных работ составляют дефектные ведомости различного вида, исходя из типа выполняемых работ для их точной классификации. После чего заполняется форма №OC-16 «Акт о выявленных дефектах оборудования». После обследования и составления дефектной ведомости принимают решение о ремонте, который должен быть выполнен собственными силами или силами подрядчика. Затем, при принятии решения о проведении ремонтных работ, следует выбрать метод осуществления ремонта. Его возможно провести как собственными силами организации, так и при помощи подрядчика. В бухгалтерском учете гостиничного бизнеса ремонтные затраты учитываются как работы по обычным видам деятельности. Стоимость ремонта зданий и сооружений гостиниц отражается в следующих унифицированных формах: форма №KС-2 «Акт о приемке выполненных работ, форма №КС-3 «Справка о стоимости выполненных работ и затрат».

Расходы на ремонт причисляют к прочим расходам для целей налогового учета. Расходы признают в том отчетном периоде, в котором они имели место, в сумме фактичес ких затрат.

Первоначальная стоимость основного средства в финансовом и налоговом учете увеличивается на сумму затрат по реконструкции и модернизации после их выполнения в случае если они привели улучшению ряда показателей функционирования объекта основных средств (к таким показателям можно отнести мощность, скорость, качество применения и срок полезного использования).

Затраты на достройку, дооборудование, реконструкцию, модернизацию объекта основных средств учитываются на счете 08 «Вложения во внеоборотные активы». После завершения работ затраты, учтенные на счете 08 «Вложения во внеоборотные активы», списывают в дебет счета 01 «Основные средства» или учитывают на этом счете обособленно. В последнем случае следует открыть отдельную инвентарную карточку на сумму произведенных затрат.

После выполнения реконструкции или модернизации срок полезного использования зданий, транспортных средств, холодильных шкафов и прочего может быть увеличен.

К распространенным затратам туристических фирм, ресторанов и гостиниц в электронной платежной системе относится подключение к сети Интернет, создание и поддержание Web-страницы. А учет расходов на подключение через выделенный канал зависит от того, как происходит подключение. Если фирма 
приобрела оборудование и кабель за свои средства, то расходы первоначально учитываются на счете 08 «Вложения во внеоборотные активы».

Гостиницы и рестораны нередко заключают договоры на техническое обслуживание оборудования, числящегося на их балансе. Список всего оборудования, подлежащего обслуживанию всегда приложен к договору. Стоимость обслуживания обычно формируется по каждой единице оборудования в отдельности. Но уже в актах выполненных работ прописывают не частную, а общую сумму обслуживания.

Время от времени следует проводить сверку фактического наличия основных средств, состоящих на обслуживании, с данными бухгалтерского учета.

В наше время трудно найти хотя бы одну гостиницу, для которой обустройство прилегающей территории не имело бы значения. Среди объектов наружного обустройства наиболее распространены различные виды архитектуры в виде скульптур, фонтанов, клумб, цветников, и прочих строений, декоративное оформление окружающих территорий, фасада гостиниц, лавки, урны и другое.

В ПБУ 6/01 «Учет основных средств» содержится информация, позволяющая делать выводы: признается ли объект внешнего благоустройства основным средством или нет. Можно выделить признаки основных средств, которым объект должен соответствовать:

1) возможно его использование сроком более 12 месяцев или в течение обычного операционного цикла, если тот превышает 12 месяцев;

2) объект внешнего благоустройства способен принос ить экономические выгоды в будущем;

3) перепродажа объекта в ближайшее время не планируе тся;

4) можно использовать для оказания услуг.
Такой объект можно принять к бухгалтерскому учету, если его первоначальная стоимость превышает 40000 p.

Согласно с п. 1 ст. 257 Налогового кодекса РФ как основные средства в целях налогообложения понимается часть имущества, используемого в качестве средств труда для производства и реализации товаров (выполнения работ, оказания услуг) или для управления организацией, первоначальной стоимостью более 100000 p.

Почти все работы, осуществляемые для благоустройства территории гостиницы, не считая уборки, отвечают требованиям, содержащимся в ПБУ 6/01 «Учет основных средств».

Согласно п. 5 ПБУ 6/01 «Учет основных средств» многолетние насаждения признаются основными средствами. Капитальные вложения в многолетние насаждения включаются в состав основных средств ежегодно в сумме затрат, относящихся к принятым в отчетном году в эксплуатацию площадям, независимо от даты завершения всей совокупности работ.

На сумму произведенных затрат делают записи по дебету счета учета основных средств и кредиту счета учета вложений во внеоборотные активы.

Бухгалтерский учет основных средств в гостинично-ресторанном бизнесе редко бывает идеально налажен. В первую очередь это касается сохранности основных средств, ведь чаще всего проводят лишь плановые инвентаризации раз в год, что слишком редко для этой сферы деятельности. В ресторанах и гостиницах необходимо проводить внеплановые выборочные проверки. В актах инвентаризации должны быть указаны:

1) дата проведения проверки;

2) способы оформления проверки;

3) состав комиссии.

После чего комиссия составляет протокол. 
Линейный способ начисления амортизации почти всегда используется в бухгалтерском учете гостиниц, но далеко не всегда он разумен, для многих объектов для их ускоренного обновления нужно применять способ уменьшаемого остатка (СВЧ печи, морозильные камеры).

В гостинично-ресторанном бизнесе распространена ошибка, связанная с формированием стоимости объектов основных средств: в первоначальную стоимость часто не включают ряд важных составляющих (стоимость услуг по оценке объектов основных средств, юридические услуги, транспортные расходы по доставке, монтажные работы по установке и другие).

Среди объектов основных средств, используемых в туризме есть некоторые виды, обладающие своей спецификой учета.

Важно отметить особенности учета инвентаря и хозяйственных принадлежностей, относящихся к основным средствам. Согласно П.4 ПБУ 6/01 в состав основных средств включается инвентарь и хозяйственные принадлежности, срок полезного использования которых превышает 12 месяцев. К ним можно причислить различные виды мебели, такие как диваны и шкафы, некоторые виды техники - стиральные машины и холодильники, газонокосилки, ноутбуки, средства пожаротушения, дорогую сантехнику. Однако в учетной политике организация может установить лимит стоимости, в рамках которого основные средства со сроком использования свыше 12 месяцев будут учитываться в составе материалов. Данный лимит не может быть выше 40000 руб. Рестораны, гостиницы и санатории с туристическими фирмами имеют в наличии различные виды автотранспорта: для экскурсий, для перевозки пассажиров, для перевозки продуктов, мебели и прочих перевозок.
Согласно п. 7 ПБУ 06/01 общая сумма всех затрат на покупку автомобиля признается первоначальной стоимостью. Такими затратами могут выступать: договорная стоимость имущества, услуги по доставке, доплата посредническим организациям, таможенные пошлины, различные затраты касающиеся регистрации и оформления документов и многие другие.

Почти всегда стоимостная величина стандартного комплекта инструментов и запасного колеса с покрышкой, ободной лентой и камерой.

Приобрести автомобиль для своих целей можно:

1) купив его (при этом фирма снизит налог на прибыль, ведь на стоимость автомобиля начисляется амортизация пропорциональ но снижающая налоговую базу по данному налогу);

2) приобретая посредством кредита или займа (в этом случае немалым плюсом выступает то, что выплата по задолженности производится через промежуток времени, что нередко выгодно, учитывая фактор инфляции);

3) взяв в лизинг (чаще всего в лизинг берут грузовики и автобусы, арендуют редко), учитывать на своем балансе могут обе стороны, и следует это определить в договоре, преимуществом лизинга является то, что амортизацию можно начислять гораздо быстрее, что выгодно стороне, у которой имущество учитывается на балансе, лизинговые платежи тоже снижают базу по налогу на прибыль.

В заключение стоит отметить важность и актуальность бухгалтерского учета основных средств в ресторанах и гостиницах. Чем выше их уровень, тем больше там числится объектов основных средств. Несправедливо считать учет вышеупомянутых объектов сугубо уделом производственных и сельскохозяйственных предприятий. 


\section{ЛИТЕРАТУРА}

1. Положение по ведению бухгалтерского учета и бухгалтерской отчетности в РФ: Приказ Минфина РФ от 29.07.98 г. №34н (в ред. от 24.12.10 г.) // СПС КонсультантПлюс. - Москва, 2016.

2. Положение по бухгалтерскому учету «Учетная политика организации» (ПБУ $1 / 08$ ): Приказ Минфина РФ от 06.10.08 г. №106н (в ред. от 18.12.12 г.) // СПС КонсультантПлюс. - Москва, 2016.

3. Положение по бухгалтерскому учету «Учет основных средств» (ПБУ 6/01): Приказ Минфина РФ от 30.03.01 г. №26н (в ред. от 24.12.10 г.) // СПС КонсультантПлюс. Москва, 2016.

4. Методические указания по бухгалтерскому учету основных средств: Приказ Минфина РФ от 13.10.03 г. №91н (в ред. от 24.12.10 г.) // СПС КонсультантПлюс. Москва, 2016.

5. План счетов бухгалтерского учета финансово -хозяйственной деятельнос ти предприятий и Инструкция по его применению: Приказ Минфина РФ от 31.10 .00 г. №94н (в ред. от 08.11.10 г.) // СПС КонсультантПлюс. - Москва, 2016.

6. Калибатов, 3.М. Бухгалтерский учет инвестиций в форме капитальных вложений / 3.М. Калибатов, И.Н. Костюкова // В сборнике: Экономика: актуальные проблемы исследований на современном этапе. Материалы международной научно-практической конференции. - Краснодар: Краснодарский центр научно-технической информации, 2016.- С. 191-196.

7. Луговский, Д.В. Резерв на ремонт основных средств: за и против // В сборнике: Экономика: актуальные проблемы исследований на современном этапе. Материалы международной научно-практической конференции. Краснодар: Краснодарский центр научно-технической информации, 2016. - С. 260-266.

8. Луговский, Д.В. Проблемы признания оценочных обязательств в части ремонта основных средств / Д.В. Луговский, Р.А. Тхагапсо, А.А. Шульга // Вестник Адыгейского государственного университета. Серия 5: Экономика, 2015. №2 (160). - С. $140-148$.

9. Луговский, Д.В. Бухгалтерский учет долгосрочных инвестиций / Д.В. Луговский, 3.А. Шеуджен // В сборнике: Апрельские научные чтения имени профессора Л.Т. Гиляровской. Материалы IV Международной научно-практической конференции. Министерство образования и науки РФ. - Воронеж: ФГБОУ ВО «Воронежский государственный университет», 2015. - С. 60-63. 


\title{
ОБ ОСОБЕННОСТИ ПРИМЕНЕНИЯ ТЕРРИТОРИАЛЬНЫХ РАЗЛИЧИЙ НАЛОГООБЛОЖЕНИЯ В НАЛОГОВОЙ ОПТИМИЗАЦИИ (НА ПРИМЕРЕ ЕНВД В ГОСТИНИЧНОМ БИЗНЕСЕ)
}

Тхакушинова С.A. студентка, Адыгейский государственный университет, г. Майкоп Научный руководитель: Силина Т.A. к.э.н., доцент, Адыгейский государственный университет, г. Майкоп

\begin{abstract}
Аннотация: В данной статье на примере единого налога на вмененньй доход (ЕНВД) рассмотрено влияние различий в элементах налогообложения на выбор размещчения гостиничных объектов. Показано значительное изменение величины ЕНВД для гостинии, ориентированных на гостей г. Майкопа, за счет расположения в прилегаюших поселениях. Ключевые слова: Единый налог на вмененный доход (ЕНВД), малый бизнес, гостиница, отель, туризм, налоговое планирование, налоговая оптимизащия
\end{abstract}

\section{ON THE FEATURES OF TERRITORIAL DISTINCTIONS OF THE TAXATION IN TAX OPTIMIZATION (ON THE EXAMPLE OF THE SINGLE TAX ON IMPUTED INCOME IN HOTEL BUSINESS)}

Tkhakushinova S. A. student, Adygei state university, Maikop Research supervisor: Silina T.A. Cand.Econ.Sci., associate professor, Adygei state university, Maikop

\begin{abstract}
In this article on the example of the single tax on imputed income (ENVD) influence of distinctions in taxation elements, at choice of placement of hotel objects is considered. Considerable change of size ENVD for the hotels focused on guests of Maikop at the expense of an arrangement in adjacent settlements is shown.

Keywords: the single tax on imputed income, hotel, small business, tourism, tax planning
\end{abstract}

В условиях экономической турбулентности создание нового предприятия должно базироваться на тщательном предварительном анализе внутренних и внешних факторов, оказывающих влияние на эффективность предпринимательской деятельности.

Уплата налоговых и иных обязательных платежей является одним из основных направлений использования финансовых ресурсов организации (предпринимателя), поэтому выбор налогового режима и оценка всех возможных способов оптимизации налоговых расходов являются тактически и стратегически важной задачей при осуществлении коммерческой деятельности.

Поскольку по ряду налогов (в т.ч. специальным налоговым режимам) субъекты РФ и муниципальные образования имеют право самостоятельно определять некоторые элементы налогообложения, одним из способов оптимизации налоговых расходов является выбор места размещения (регистрации) предприятия или организации. Ярким примером территориальных различий в налогообложении в России является единый налог на вмененный доход.

Гостиница (Отель) - предприятие, предоставляющее услуги размещения и, в большинстве случаев, услуги питания населению, имеющие службу приема и оборудование для оказания дополнительных услуг [1].

Единый налог на вмененный доход для отдельных видов деятельности (ЕНВД) представляет собой один из специальных налоговых режимов, предусмотренных в НК 
РФ (гл. 26.3) для субъектов малого бизнеса [2]. Среди тех, кто имеет право его применять, есть и гостиницы с площадью помещений для временного размещения и проживания, не превышающей $500 \mathrm{M}^{2}$.

В общем виде ежеквартальная сумма единого налога рассчитывается по формуле:

$$
\text { ЕНВД }=\text { БД*Фпок* } \kappa_{1} * K_{2} * 0,15,
$$

где БД - базовая доходность (рублей в месяц), установленная в НК РФ;

Фпок - физический показатель, характеризующий соответствующий вид деятельности. Для гостиниц это площадь спальных помещений в квадратных метрах;

К1 - коэффициент-дефлятор (на 2015 г. установлен в размере 1,798 );

К2 - корректирующий коэффициент, устанавливаемый органами муниципальных районов, городских округов.

Вопросы применения ЕНВД помимо НК РФ регулируются решениями (постановлениями) советов народных депутатов муниципального образования, где применяется данный налоговый режим. Для каждого муниципального образования установлены своизначения К2, величина которого зависит от численности жителей населенный пунктов [3, c. 10]. Отметим, что в отношении объектов для временного размещения проживающих, по нашему мнению, определяющими величину вмененного дохода, должны быть иные факторы (туристическая привлекательность территориального образования, промышленный и экономический потенциал и др.), поскольку местные жители услугами гостиниц пользуются редко.

В данной статье мы рассмотрели изменение налоговой нагрузки на гостиницу, уплачивающую ЕНВД, в зависимости от места ее размещения в пределах 20-30 км от центра г. Майкопа. Выбирались населенные пункты, которые расположены вблизи основных автомобильных трасс, это, в свою очередь обеспечивает достаточный поток клиентов за счет удобных для них маршрутов. В состав рассматриваемых территорий попали административно-территориальные

образования г. Майкопа и Майкопского района Республики Адыгея, а также Белореченского района Краснодарского края, последние рассматривались с точки зрения ориентации так же и на постояльцев из г. Белореченск.

Расчетпроведендля максимально допустимой площади помещений для временного размещения и проживания -500 м $^{2}$ (табл.).

Таблица 1 - Территориальная величина годового ЕНВД для гостиницы смаксимальной площадью помещений для временного размещения и проживания (500 $\left.\mathrm{M}^{2}\right)$

\begin{tabular}{|c|c|c|}
\hline Населенный пункт & $\mathrm{K} 2$ & Сумма налога, руб. \\
\hline \multicolumn{3}{|l|}{ MO Майкоn } \\
\hline г. Майкоп & 0,75 & 404550 \\
\hline ст. Ханская & 0,60 & 323640 \\
\hline п. Северный, Гавердовский, Родниковый & 0,45 & 242730 \\
\hline х. Веселый, Подгорный, Косинов & 0,30 & 161820 \\
\hline \multicolumn{3}{|l|}{ МО Майкопский район } \\
\hline $\begin{array}{l}\text { п. Табачный, х. Пролетарский, х. Северо-Восточные сады, п. Краснооктябрьский, } \\
\text { п. Удобный, п. Совхозный, ст. Кужорская, п. Тульский }\end{array}$ & 0,3 & 161820 \\
\hline х. Садовый, п. Победа, х. Грозный, п. Приречный, х. Советский, х. Грозный & 0,2 & 107880 \\
\hline \multicolumn{3}{|l|}{ МО Белореченский район } \\
\hline г. Белореченск & 0,700 & 377580 \\
\hline п. Родники, п. Южный & 0,610 & 329034 \\
\hline п. Восточный, х. Грушовый, п. Заречный, п. Новый, п. Садовый & 0,580 & 312852 \\
\hline
\end{tabular}

\footnotetext{
* Составлено автором
} 
При этом использовалась формула

исчисление единого налога за квартал:

$$
\text { ЕНВД }=1000 * 500 * 1,798 * К 2 * 0,15 \text {, }
$$

где К2 - корректирующий коэффициент, устанавливаемый органами муниципальных районов, городских округов.

Очевидно, что размещение гостиницы в том или ином муниципальном образовании значительно влияет на величину ЕНВД: годовая сумма налога может отличаться до 3,75 pas.

Таким образом, проведенные расчеты показали, что различные подходы субъектов РФ, а также муниципальных образований, могут использоваться хозяйствующим и субъектами в оптимизации своих налоговых платежей $[4$, с. 6], [5, с 210]. Так, более низкое значение К2 позволит высвободить часть финансовых ресурсов при уплате ЕНВД и направить их развитие деятельности, а удаленность от шумных потоков, расположение в тихом и живописном месте может стать конкурентным преимуществом гостиницы. Безусловно, далеко не каждый вид деятельности допускает налоговую оптимизацию путем изменения места размещения, поскольку налоговая экономия может оказаться значительно ниже потерь в виде недополученных доходов. Но такой инструмент всегда необходимо учитывать и соотносить потенциальный доход с возможностью налоговой оптимизации.

\section{ЛИТЕРАТУРА}

1.ГОСТ Р 53423-2009 Туристские услуги. Информация для потребителей. Общие требования [Электронный ресурс]. http://www.consultant.ru/cons/cgi/online.c gi ?req=doc \&base $=0 T N \& n=5002 \# 0$.

2. Налоговый кодекс Российской Федерации (часть вторая): федер. закон от 05.08.00 № 117-ФЗ РФ (в ред. от 05.04.2016) [Электронный ресурс]. - Режим доступа: http://mobileonline.garant.ru/\#/document/10900200/paragraph/1:9

3. Карпенко, С.В. Основы налогообложения малого бизнеса в России: учеб.пособие / С.В. Карпенко, Т.А. Силина. - Майкоп: Изд-во АГУ, 2015. - 284 с.

4. Карпенко, С.В. Сравнительная оценка налоговой нагрузки при применении единого налога на вмененный доход и патентной системы налогообложения / С.В. Карпенко, М.Е. Ордынская, Т.А. Силина // Вестник Адыгейского государственного университета. Сер. Экономика, 2015. Вып. 1 (155). - С. 201-212.

5. Силина, Т.А. Проблема обоснованности налоговой нагрузки при вмененном налогообложении / Т.А. Силина, С.В. Карпенко, С.А. Тхакушинова // Вестник Адыгейского государственного университета. Серия 5: Экономика, 2015. № 4 (170). - С. 259-266.

6. Силина, Т.А. Об особенностях единого налога на вмененный доход для отдельных видов деятельности в Республике Адыгея / T.А. Силина, С.А. Тхакушинова // Экономика и управление в современных условиях: проблемы и перспективы сб. науч. тр. по материалам II Междунар. науч.-практ. конф./под науч. ред. А.А. Тамова. Майкоп, 2015. - С. 297-304. 


\title{
МОДЕРНИЗАЦИЯ КОНТРОЛЬНО-КАССОВОЙ ТЕХНИКИ И ЕЕ ПРИМЕНЕНИЕ
}

Хатков М.А. студент, Адыгейского государственного университета, г. Майкоп Научный руководитель: Силина Т.А. к.э.н., доцент, Адыгейский государственный университет, г. Майкоп

\begin{abstract}
Аннотация: в статье рассмотрено определение контрольно-кассовой техники, нарушения в законодательстве о применении кассовых аппаратов и административная ответственность за их неприменение, положительные и отрицательные стороны ККТ, сущность онлайн касс и их постепенное внедрение.
\end{abstract}

Ключевые слова: контрольно-кассовая техника, онлайн касса, административная ответственность, бизнес, законопроект.

\section{MODERNIZATION OF CHECK-OUT EQUIPMENT AND ITS APPLICATION}

Khatkov M.A. student, Adyge state university, Maykop Research supervisor: Silina T.A. Cand.Econ.Sci., associate professor, Adyge state university, Maykop

\begin{abstract}
: the article describes definition of check-out equipment, violation of the law on the use of cash registers and administrative responsibility for their non-use, the positive and negative aspects of the CCT, the essence of online cash desk and their gradual implementation.

Keywords: Check-out equipment, online cash desk, administrative responsibility, business, law.
\end{abstract}

Контрольно-кассовая техника необходима всем организациям и индивидуаль ным предпринимателям для проведения, как наличных денежных расчетов, так и расчетов с использованием денежных карт для осуществления продажи товаров, выполнения работ и оказания услуг.

На сегодняшний день тема модернизации ККТ имеет большую актуальность. Необходимость изменения приема и учета денежных средств, увеличение мобильности кассовых аппаратов

ИX многофункцио нальности и надежност и привело к появления онлайн касс, способных решить все вышеперечисленные требования. Таким образом, улучшенная функцио нальность контрольно-кассовой техники, увеличит мобильность, надежность совершаемых кассовых операций. Сократится количество проверок, но увеличится их результативность.
Реализуя онлайн кассы, налоговые органы смогли добиться довольно высокого результата снижения количества проверок, которые с 2011 по 2015 год уменьшились с 278 до 173 тысяч, что составило 38\%. Тем временем результативность проверок повысилась с 54 до 86 процентов.

Согласно Федеральному закону от 03.07.2016 № 290-Ф3 с 1 февраля 2017 года вместо привычных нам ККТ к ИФНС будут подключать только онлайн-кассы. А к 1 июля 2017 года представители абсолютно всего бизнеса, как малого, так и крупного, должны обновить (или модернизировать) старые ККТ на новое онлайн оборудование.

Онлайн кассы позволят отправлять информацию обо всех кассовых операция х компании налоговикам в режиме реального времени. Теперь чек будет не только в бумажном виде, но так же и в электроном, который можно будет получить по почте или 
CMC [1].

В соответствии с письмом Минфина РФ от 30.03.2016 № $03-01-$ 15/17988 налогоплательщики ЕНВД и патента, которым при некоторых условиях разрешено вообще не использовать кассовый аппарат, должны будут к 1 июля 2018 года в обязательном порядке перейти на онлайн ККТ. При этом расходы на переоборудование можно будет поставить в вычет по налогу [2].

Еще в 2003 году появилась потребность изменений в работе кассовой технике. Прошло много лет, и с изменением в законе Ф3-54 «О применении контрольно-кассовой техники», кассы станут порядком удобнее.

Для проведения такой модернизации в законе должны быть определенные показатели ее успешности. В этих целях с 2014 по 2015 год в Москве, Подмосковье, Калужской области и Татарстане был проведен запланированный эксперимент. Суть эксперимента состояла во внедрении новой ККТ - онлайн кассы. Более 4000 касс из 1000 компаний модернизировали путем оснащения модулем, передающим данные в ФНС. Результаты данного эксперимента были признаны успешными и стали большим толчком появления нового законопроекта [3].

Закон предусматривает следующие основные положения:

— Обязательная передача информации о расчетах через операторов фискальных данных в ФНС России.

- Возможность осуществления всех регистрационных действий с контрольнокассовой техники и иного юридически значимого документооборота по вопросам ее применения через личный кабинет на сайте ФНС России.

- Возможность изготовление кассовых чеков и бланков строгой отчетности дается только кассовым аппаратам с дальнейшим их направлением в электронной форме на абонентский номер или электронную почту покупателя. Теперь под кассовым чеком понимается бланк строгой отчетности.

- Обязательное применение кассовых аппаратов при оказании услуг, а также плательщиками единого налога на вмененный доход и патента.

- Необходимое применение фискального накопителя, а так же возможность его замены один раз в три года плательщиками ЕНВД и патента, а также сферы услуг. Закон не ограничивает предельные сроки применения фискального накопителя.

- Для регистрации кассового аппарата в ФНС России не обязательно техническое обслуживание.

- Проведение экспертизы произведенных кассовых аппаратов и технических средств операторов фискальных данных.

- Поэкземплярный учет ФНС России произведенных кассовых аппаратов и фискальных накопителей в форме реестров.

- При отсутствии интернета возможность применения ККТ в автономном режиме.

- Новые формы контрольных мероприятий, возможность запроса в банках информации по счетам в ходе оперативных проверок.

- Нерезкий и поэтапный переход к новому порядку применения контрольно-кассовой техники.

Во многих отдаленных местностях есть проблема обеспечения интернетом. В этим местах работа ККТ будет происходить автономно без передачи данных о продажах онлайн. Законное на то право получат только некоторые населенные пункты, списки которых сформируются позже [4].

Этапы перехода на онлайн кассы:

1) Начиная с $15.07 .16 \quad$ г., будет осуществляться добровольный переход на онлайн кассы. 
2) Начиная с 1.02 .17 г., подключение к ИФНС будет только для онлайн класс.

3) Начиная с 1.07.17 г., весь бизнес будет обязан перейти на новую ККТ - онлайн кассы.
4) Начиная
c
1.07 .18
г., все

налогоплательщики ЕНВД и патента будут обязаны применять онлайн кассы.

Подводя итоги можно выделить список обязанностей, необходимый для соблюдения с 1 июля 2017 года (патент и ЕНВД с 1 июля 2018 года) [5]:

1. Необходимо модернизировать фискальную технику, если это возможно, либо приобрести новую.

2. Необходимо зарегистрировать ККТ в налоговой либо перерегистрировать.

3. Необходимо заключить договор об обработке фискальных данных с одним из ОФД (оператором фискальных данных)
4. Необходимо обеспечивать исправную работу ККТ и передачу каждого чека в ОФД, который затем передает эти данные в налоговую.

5. Необходимо высылать клиенту чек в электронном виде или, по его требованию, выдавать бумажный.

6. Необходимо один раз в 15 месяцев производить замену блока фискальной памяти.

\section{7. Необходимо} контролировать сохранность фискальных накопителей не менее 5 лет с даты их регистрации в налоговых органах.

Переход на онлайн кассы постепенно приведет к тому, что серый бизнес будет постепенно вымываться, и на рынке будет восстанавливаться нормальная здоровая конкуренция.

\section{ЛИТЕРАТУРА}

1.Федеральная налоговая служба. Новый порядок применения ККТ. [Электронный ресурс]. - Режим доступа: https://www.nalog.ru/rn77/taxation/reference_work/newkkt/.

2. Налоги и бухгалтерия. Онлайн кассы 2017 года. [Электронный ресурс]. - Режим доступа: http://ip-spravka.ru/news/online-kassa-2016

3. Применение ККТ. [Электронный ресурс]. - Режим доступа: http://www.moysklad.ru/izmenenija-v-54-fz/.

4. Кассовые аппараты с 2016 года. [Электронный ресурс]. - Режим доступа: http://www.moysklad.ru/izmenenija-v-54-fz/kassovye-apparaty-s-2016-goda/.

5. Автоматизация бизнеса. [Электронный ресурс]. - Режим доступа: http://www.1 cab.ru/ab/news/Utochnenysrokivstupleniyavsilupopravokk54FZOprimeneni ikontrolnokassovoytekhniki/.

6. Карпенко, С.В. Развитие государственного контроля доходов налогоплательщиков в современной России / С.В. Карпенко, Т.А. Силина // Современный научный вестник, 2016. Т. 10. - С. 85-89.

7. Силина, Т.А. Бухгалтерское программное обеспечение: проблемы выбора и освоения / Т.А. Силина, М.Е. Ордынская, С.В. Карпенко // Sworld: сб. науч. тр., 2012. Т. 18. № 1. - C. $5-7$.

8. Цирульникова, К.М. Проблемы и преимущества перехода на облачную бухгалтерию / К.М. Цирульникова, Т.А. Силина // Экономика: актуальные проблемы исследований на современном этапе: материалы междунар. науч.-практ. конф., 2016. - С. 216 220 . 
9. Налоговый кодекс Российской Федерации (часть вторая): Федеральный закон от 05.08.2000 № 117-Ф3 (в ред. от 22.05.2003) // СПС «КонсультантПлюс»- Москва, 2016.

10. Налоговый кодекс Российской Федерации (часть вторая): Федеральный закон от 05.08.2000 № 117-Ф3 (в ред. от 03.07.2016) // СПС «КонсультантПлюс» - Москва, 2016. 


\title{
БУХГАЛТЕРСКИЙ УЧЕТ ВЫРУЧКИ: МЕЖДУНАРОДНЫЙ ПОДХОД
}

Хашиг И.О. студентка, Адыгейский государственнылй университет, г. Майкоп Бекирова К.Н. к.э.н., доиент, Адыгейский государственный университет, г. Майкоп

\begin{abstract}
Аннотация: В представленной статье раскрываются положения нового международного стандарта финансовой отчетности по признанию выручки МСФО (IFRS) 15 «Bыручка по договорам с покупателями». В ходе анализа выявлено влияние изменений на учет финансовых результатов деятельности экономических субъектов в связи с принятием нового МСФО.

Ключевые слова: Выручка, МСФО, договор с покупателем, дополнительные затраты, активьь.
\end{abstract}

REVENUE ACCOUNTING: INTERNATIONAL APPROACH.

Khashig I.O. student, Adygei state university, Maikop

Bekirova K.N. Cand.Econ.Sci., associate professor, Adygei state university, Maikop

\begin{abstract}
In the provided article provisions of a new international accounting standard on a revenue recognition of IFRS (IFRS) 15 "Revenue" reveal. During the analysis influence of changes on accounting of financial results of activities of economic actors in connection with adoption of new IFRS is revealed.
\end{abstract}

Keywords: Revenue, IFRS, the contract with the buyer, the additional costs, assets.

Проводя анализ финансового положения организации, наравне с чистой прибылью выручку считают важнейшей статьей финансовой отчетности. В то же время без оценки выручки, которая, в свою очередь, занимает наиболее значительную статью отчета о совокупном доходе, чистая прибыль не может быть достоверно определена. Инвесторы, кредиторы и другие пользователи финансовой отчетности при оценке финансового состояния организации сначала рассчитывают величину и структуру выручки, которая признается в текущем отчетном периоде, включая сравнение с предыдущим отчетным периодом, а также с выручкой иных сравниваемых организаций. В условия повышения значимости международных стандартов для национальной системы бухгалтерского учета и финансово й отчетности оценка международного подхода к отражению выручки организации является крайне актуальной.

В мае 2015 г. Совет по МСФО издал новый стандарт МСФО (IFRS) 15 «Выручка по договорам с покупателями», который должен был вступить в силу в отношении годовых отчетных периодов, которые начинаются с 1 января 2017 г. или после данной даты. Но уже в сентябре 2015 г. Совет выпустил поправку, в соответствии с которой данная дата была перенесена на 1 января 2018 г. Но до этой даты применение стандарта возможно по желанию организации, т.е. законодательно допускается его досрочное применение.

С вступлением в силу МСФО (IFRS) 15 утратят силу МСФО (IAS) 18 «Выручка» и МСФО (IAS) 11 «Договоры на строительство», равно как и несколько разъяснений (КРМФО (IFRIC) 13 «Программы лояльности клиентов», КРМФО 
(IFRIC) 15 «Соглашения на строительство объектов недвижимости», КРМФО (IFRIC) 18 «Передача активов от клиентов», ПКР (SIC) 31 «Выручка - бартерные операции, включающие рекламные услуги»).

MCФO (IFRS) 15 охватывает не только те новые договоры, которые заключены со дня вступления в силу МСФО (IFRS) 15, но и на уже заключенные договоры, которые не будут осуществлены к дате утверждения МСФО.

Цель настоящего стандарта состоит в установлении принципов, которых обязана придерживаться компания при представлении необходимой и полезной финансовой отчетности заинтересованным пользователям, в которой раскрывается информация о формах, сроках и неопределенности возникновения, а также о величине выручки и денежных потоков, которые обусловлены договором с покупателями.

В соответствии с МСФО 15 во время заключения договора организация обязана оценивать товары или услуги, которые были обещаны в соответствии с договором с покупателем, и установить каждое обещание передать покупателю как обязанность к исполнению:

1) товар или услугу (или набор товаров или услуг), которые являются отличимыми;

2) группа различных товаров или услуг, которые являются практически сходными и передаются покупателю по сходной схеме.

Экономический субъект должен принимать к учету выручку, когда (или по мере того, как) он исполняет обязанность посредством передачи обещанного товара или услуги (т.е. актива) покупателю. Актив передается, когда (или по мере того, как) покупатель приобретает контроль над таким активом [4]. Затраты по договорам с покупателями - это дополнительные (incremental) затраты, кото- рые связаны не только с заключением договоров с покупателями, но и с исполнением таких договоров.

Данные активы амортизируются на постоянной основе в течение, согласованного со схемой передачи тех товаров или услуг периода, к которым они напрямую относятся [1].

МСФО 15 используется для учета затрат, относящихся к выполнению договора. Но если эти затраты относятся к сфере применения иных функционирующих стандартов финансовой отчетности (например, МСФО (IAS) 2 «Запасы», МСФО (IAS) 16 «Основные средства», МСФО (IAS) 38 «Нематериальные активы») [4].

По части дополнительных затрат, которые сопряжены с заключением договоров с покупателями, МСФО 15 указывает, что, если экономический субъект предполагает возмещение этих затрат в дальнейшем и если период их амортизации больше года они признаю тся как активы. Но в том случае, когда их амортизации меньше года, они признаются как расходы.

Когда одновременно выполняются все следующие условия, то относящиеся на выполнение договоров с покупателями расходы, признаются в качестве активов:

1) относятся напрямую на предполагаемый или существующий договором, который организация может конкретно определить;

2) улучшают либо создают запасы организации, которые в дальнейшем будут направляться на выполнения обязательств по договоpaм;

3) в дальнейшем предполагается данные затраты возместить.

Это, к примеру, такие затраты как:

1) прямые материальные затраты;

2) затраты по оплате труда;

3) разделение накладных затрат, которые напрямую связаны с договором; 
4) затраты, подлежащие к возмещению покупателем;

5) другие затраты, появившиеся лишь по причине того, что был заключен договор с покупателем [4].

Целью информации, которая раскрывается в соответствии с МСФО 15, является предоставление пользователям отчетности возможности понять характер, величину и момент принятия к учету выручки, а также неопределенность, связанную с выручкой и денежными потоками, возникающими в результате исполнения обязательств по договорам с покупателями. Подобными представлениям и данных могут быть:

1) выручка, которая признана в соответствии с договором с покупателем, включая разделение выручки на элементы;

2) балансы по договорам;

3) выручка, которая признается в отчетном году, которая была включена во входящие остатки по договорным обязательствам;

4) выручка, признанная в отчетном периоде по договорным обязательствам, исполненным в предыдущих периодах;

5) форму товаров и услуг, которые обещаны к передаче по договорам;

6) обязательства по возвратам и возмещениям и прочим подобным обязательствам;

7) типы гарантий и других подобных обязательств;

8) прочее.

Организация отражает в отчете о финансовом состоянии как договорной актив или договорное обязательство данные о выполнении условий договоров с покупателями, в зависимости от уровня выполнения обязательств экономическим субъектом и свершения платежей покупателями в пределах договоров.

Отражается отдельно как дебиторская задолженность любое безоговорочное право на вознаграждение [1].
В том случае, когда организация передала контроль покупателю над соответствующим товаром или услугой, он совершил предоплату, в отчете о финансовом положении представляется договорное обязательство.

Но если же покупатель пока не осуществил платеж за передачу товара или услуги соответствующее вознаграждение, то в отчете о финансовом состоянии отражаются:

1. Право экономического субъекта на вознаграждение в обмен на товары или услуги, которые были переданы покупателю, которое обусловлено причиной иной, чем течение времени - договорной актив;

2. Безоговорочное право на вознаграждение, которое не зависит от течения времени, т.е. как дебиторская задолженность.

Необходимо отражать договорной актив и дебиторскую задолженность и любое обесценение, относящееся к ним, в соответствии с МСФО (IFRS) 9 «Финансовые инструменты».

Следует признавать как расходы от обесценения соответствующую разницу между первоначально признанной суммой выручки и суммой дебиторской задолженности.

МСФО 15 окажет влияние на экономические субъекты, но в разной степени, с учетом вида их деятельности.

К примеру, кредитные организации, как ожидается, будут подвержены в наименьшей мере, из-за того, что МСФО 15 не охватывает процентный доход, который составляет наибольшую часть дохода банка, равно как и на доход от дивидендов.

МСФО 15 в наибольшей степени, как ожидается, окажет влияние на деятельность, которая связана со строительством, фармацевтикой, сделками с недвижимостью, управлением активами, франчайзингом, разработкой программного обеспечения, телекоммуникациями, включая мобильные сети и кабельные линии связи [2]. 
В зависимости от вида деятельности организации-продавца тоже может зависеть степень раскрываемой информации.

Наиболее существенно МСФО 15 повлияет на договоры с многочисленными поставками, многоэлементные договора, которые включают поставку, настройку, разработку дизайна, последоговорное обслуживание и установку обновлений. Указанные элементы могут представлять собой отдельные обязательства, которые подлежат исполнению и на них понадобится распределять цену сделки на основе иной цены продажи элемента.

Договоры, которые предусматривают изменения в цене в зависимости от наступле ния событий, наличия права на возврат, ценообразования, базирующегося на дисконтах или степени выполнения целей, необходимо будет анализировать с точки зрения переменного вознаграждения, применяя предположения и анализ, включать его в общую цену сделки и отражать в отчетности в качестве элемента выручки [1].

Необходимым становится выявление затрат в отношении затрат на потерю трудовых ресурсов и материальных из-за нерациональной, нерентабельной и нерезультативной деятельности, которые невозможно капитализировать, а также капитализируемых затрат например, на обучение (learning curve costs), на активацию и представление. Следует определять и представлять в информационную систему базис для амортизации этих затрат например, в зависимости от срока действия договора, при этом разграничив договоры со сроком действия свыше года и до года (в этом случае затраты относятся на расходы).

Возникает необходимость в первую очередь проанализ ировать:

1) наиболее значимые виды потоков выручки, а также оценить основные формы договоров, непосредственно образующих данную выручку, уделяя особое внимание переходящим договорам на долгосрочной основе, в части необходимости внесения в них изменений и потенциальной интеграции их существенных условий, влияющих на признание договорных активов, договорных обязательств и выручки, в учетную систему; возможно, потребуются дополнительные знания в области национального и международного законодательства в части подлежащих исполнению обязательств по договорам с покупателями;

2) необходимость внесения изменений в информационные системы сведений о договорах, которые, согласно МСФО 15, существенны в части признания выручки, а также в системы внутренних контролей, в ключевые показатели рентабельности (KPI), системы вознаграждения и премирования, дивидендную политику;

3) необходимость корректировки степени взаимодействия и информационного обмена между учетными работниками и работниками, которые несут ответственность за продажи. Он требуется для точного и соответствующего признания выручки в установленный момент времени или по мере исполнения обязательств по договору, исполнения требующих раскрытий, а так же в части договорных активов и договорных обязательств;

4) степень влияния новых методов к признанию выручки на финансовый результат, показатели финансового положения, активы и обязательства, в том числе с точки зрения инвесторов, а также выполнение соглашения.

Стандарт требует, чтобы организации раскрывали достаточно информации, которая позволит всем заинтересованным пользователям финансовой отчетности понять характер, распределение во времени, сумму, величину, стоимость и неопределенность выручки и денежных 
потоков, исходящих из договоров с сохранив возможность его досрочного покупателями.

использования, компаниям рационально

Невзирая на то, что после длительных преждевременно разработать подходы к его обсуждений Совет по МСФО отложил применению.

принятие стандарта на 1 января 2018 г.,

\section{ЛИТЕРАТУРА}

1. Гражданский Кодекс Российской Федерации (часть четвертая): Федеральный закон от 18.12.2006 г. №230-Ф3 (в ред. от 03.07.2016 г.) // СПС КонсультантПлюс. Москва, 2016.

2. Налоговый Кодекс Российской Федерации (часть вторая): Федеральный закон от 05.08.2000 г. №117-Ф3 (ред. от 19.05.2010 г.) // СПС КонсультантПлюс. - Москва, 2016.

3. Об утверждении Программы реформирования бухгалтерского учета в соответствии с международными стандартами финансовой отчетности: Постановление Правительства РФ №283 от 06.03.1998 // СПС КонсультантПлюс. - Москва, 2016.

4. Международный стандарт финансовой отчетности (IFRS) 15 «Выручка по договорам с покупателями» (введен в действие на территории Российской Федерации Приказом Минфина России от 27.06.2016 №98н) // СПС КонсультантПлюс.- Москва, 2016. 


\title{
ВЗАИМОДЕЙСТВИЕ АУДИТА И ЭКОНОМИЧЕСКОГО АНАЛИЗА
}

Хоретлева Б.М.

студентка, Адыгейский государственный университет, г. Майкоп

Научный руководитель: Таусова И.Ф.

к.э.н., доиент, Адыгейский государственный университет, г. Майкоп

\begin{abstract}
Аннотация: В исследовании было проанализировано понятие «аудит». Данное понятие было раскрыто на законодательном уровне, а также рассмотрено с различных точек зрения авторов в экономической литературе. Также было рассмотрено понятие экономического анализа и его предмет. В работе были приведены иели и задачи как аудита, так и экономического анализа. В результате проведенного исследования, был сделан вывод, что экономический анализ и аудит по сути имеют разное направление и ичели, но при этом тесно переплетаются в экономической жизни.
\end{abstract}

Ключевые слова: экономический анализ, аудит, аналитические процедуры.

\section{INTERACTION OF AUDIT AND ECONOMIC ANALYSIS}

Horetleva B.M. student, Adyghe state university, Maykop

Research supervisor: Tausova I.F. Cand.Econ.Sci., associate professor, Adyghe state university, Maykop

\begin{abstract}
The term "audit» has been analyzed in the study. This concept was revealed at the legislative level, and also considered from various points of view of the authors in the economic literature. It was also discussed the concept of economic analysis and its object. In this paper we were presented the goals and objectives as the audit and economic analysis. As a result of the study, it was concluded that the economic analysis and audit in fact have a different direction and purpose, but are closely intertwined in economic life.
\end{abstract}

Keywords: economic analysis, audit, analytical procedures.

В настоящее время существует проблема определения степени взаимодействия экономического анализа и аудита. В исследовании были рассмотрены базовые понятия этих двух наук.

Понятие «аудит» закреплено на законодательном уровне, а именно в Федеральном законе от 30.12.2008 г. № 307 Ф3 (ред. от 03.07.2016 г.) «Об аудиторской деятельности». По мнению законодателей аудит представляет собой независимую проверку бухгалтерской (финансовой) отчетности аудируемого лица в целях выражения мнения о достоверности такой отчетности.

При этом в экономической литературе, посвященной аудиту, даны различные по формулировке определения, но близких по существу. К примеру, Аксененко А. Ф. считает, что аудит - это независимая экспертиза, анализ публичной отчетности организации [1].

Из определений аудита вытекает его основная цель - установление достоверности финансовой отчетности субъектов хозяйствования при достоверности хозяйственных операций законодательству РФ.

Для достижения данной цели перед аудитором стоят следующие задачи:

1) оценить уровень бухгалтерского учета, квалификации кадров, правиль ности и законности отражения фактов хозяйственно й жизни;

2) оказать помощь руководству аудируемого лица по устранению недостатков, особенно 
существенных нарушений, которые повлияли на финансовые результаты;

3) выявить факты не только прошлых лет и существующих в данный момент положений, но и ориентировать руководства проверяемой организации на будущие события, которые способны повлиять на хозяйственную деятельность и конечный результат;

4) оказать помощь организациям по защите их интересов в налоговых органах и арбитражных судах.

При осуществлении профессионально й аудиторской деятельности аудитору необходимо получить информацию о состоянии бизнеса клиента и перспективах его функционирования. Данный аспект закреплен в федеральном правиле (стандарте) аудиторской деятельности №8 «Понимание деятельности аудируемого лица, среды, в которой она осуществляется, и оценка рисков существенного искажения аудируемой финансовой (бухгалтерской) отчетности».

Среди процедур, рекомендуемых стандартом, особое место занимают аналитические процедуры. Их назначение состоит в выявлении показателей, коэффициентов и тенденций, сигнализирующих о ситуациях, при которых возникают проблемы, влияющие на достоверность отчетности проверяемого лица.

Переходя к понятию экономического анализа, можно сказать, что анализ, в общем понимании, - это синтез содержания и формы человеческого мышления. Он комплексно изучается многими науками. Но анализ экономики, анализ хозяйственно й деятельности и ее конечных результатов - это область исключительно экономического анализа.

Экономический анализ - как практика, есть вид управленческой деятельности, предшествующий принятию управленческих решений и сводящийся К обоснованию решений на базе имеющиеся информации. Экономический анализ оказывает влияние на повышение экономической эффективности деятельности организации, укрепление ее финансового состояния.

В этой связи под предметом экономического анализа чаще всего понимают хозяйственный процесс предприятий, объединений, ассоциаций конечные финансовые результаты их деятельности, складывающиеся под воздействием объективных и субъективных факторов, получающие отражение через систему экономической информации.

Целью экономического анализа является обнаружение и использование резервов повышения эффективности деятельности предприятия, обеспечение рентабельно й работы организации.

Задачами экономического анализа являются: - повышение научных экономически обоснованных бизнес-планов, бизнеспроцессов и нормативов (в процессе их разработки);

- объективное и всестороннее исследование выполнение бизнес планов, а также бизнес процессов и соблюдение нормативов (по данным учета и отчетности); - определение результативности использования трудовых, материальных и финансовых ресурсов;

- контроль за осуществлением требованиям коммерческого расчета;

- выявление и измерение внутренних резервов на всех стадиях производственного процесса;

- проверка оптимальности управленческих решений;

- прогнозирование ожидаемых результатов хозяйственной деятельности.

Тем самым подводя итог, можно сказать, что анализ направлен на прогнозирование деятельности организации, а аудит на 
констатацию достоверности учета и формируется оценка достоверности отчетности. Главная функция анализа - проверяемого объекта учета. Данная оценка прогнозирование, аудита - фискальная . Аналитик опирается на текущие факты является косвенным свидетельством, на основе которого аудитор принимает решение экономической жизни и планирует будущее, а аудитор опирается на прошедшие событие и дает им оценку. Это их принципиальное отличие друг от друга.

Многие авторы высказывали мнение о взаимодействии аудита и анализа. Например, Перминова К. К. указывает на применения аудитором аналитических процедур в ходе аудита, таких как:

1. Анализ взаимосвязей бухгалтерской отчетности и натуральных показателей;

2. Сравнение фактических данных с данными за предыдущие периоды;

3. Анализ изменений в течении времени данных бухгалтерской отчетности;

4. Изучение различных отклонений и причин возникновений [4].

Необходимость во всестороннем анализе аудируемой организации возникает уже на предварительной стадии любой аудиторской проверки. Входе подготовки к проверке в соответствии со стандартом аудиторской деятельности, аудитор должен ознакомится с финансово-хозяйственной деятельностью экономического субъекта и иметь информацию о внешних и внутренних факторах, влияющих на его хозяйственную деятельности. В результате анализа

о необходимости применения других аудиторских процедур [5].

На стадии детальной проверки анализ служит для снижения риска необнаружения каких-либо отклонений.

На завершающей стадии аудита анализ применяется для того, чтобы аудитор в ходе оценки результатов проведенного аудита мог обобщить данные и сделать выводы.

Также Потапова О. С. рассматривает применение конкретных коэффициентов экономического анализа при анализе финансовой отчетности. Таких как коэффициент текущей и абсолютной ликвидности, коэффициент автономии и др. [6].

Таким образом, аудит не может существовать обособленно от анализа, поскольку при аудите применяются аналитические процедуры. И анализ не может обходиться без аудита, поскольку аналитик не может строить прогноз на недостоверных данных фактов хозяйственной деятельности. Подводя итог, можно сказать, что экономический анализ и аудит, по сути, имеют разное направление и цели, но при этом тесно переплетаются в экономической жизни.

\section{ЛИТЕРАТУРА}

1.Аксененко, А. Ф. Аудит: современная организация и развитие // Бухгалтерский учет, 2004. № 4. - C. 7-9.

2. Бондарев, П. В. Место и роль анализа в аудите // Проблемы и перспективы развития рынка аудиторских услуг России. - Курск: Курская государственная сельскохозяйственная академия, 2015.- С. 26-28.

3. Говдя, В.В. Исследование аналитических данных с помощью методов и приемов внутреннего аудита / В.В. Говдя, Т.А. Силина // Нормативные акты для бухгалтера Краснодарского края, 2007. № 7. - С. 15-18.

4. Ларичев, А. Ю. Экономический анализ в налоговом аудите. - М.: Финансовая академия при Правительстве Российской Федерации, 2005. - С. 20. 
5. Перминова, К. К. Применение методов экономического анализа в аудите // Бухгалтерский учет, управление и финансы: Перспективы развития в условиях экономической нестабильности. - Саратов: Саратовский социально-экономический институт (филиал) федерального государственного бюджетного образовательного учреждения высшего образования «Российский экономический университет им. Г. В. Плеханова», 2016. - С. 134-138.

6. Таусова, И.Ф. Концепции аудиторской деятельности: задачи, проблемы, решения // Приоритетные научные направления: от теории к практике, 2015. - С. 173-175.

7. Потапова, О. С. Использование результатов экономического анализа в аудите // Проблемы и перспективы развития рынка аудиторских услуг России. - Курск: Курская государственная сельскохозяйственная академия им. профессора И. И. Иванова, 2015. - C. $148-151$. 


\title{
ОСОБЕННОСТИ ФИНАНСОВОЙ ОТЧЕТНОСТИ В ЗАРУБЕЖНЫХ СТРАНАХ
}

Хоретлева Б.М., Мирзова С.Г. студентка, Адыгейский государственнылй университет, г. Майкоп Научный руководитель: Водождокова 3.А. к.э.н., доиент, Адыгейский государственный университет, г. Майкоп

\begin{abstract}
Аннотация: B статье обобщен зарубежный опыт составления финансовой отчетности организаций, указаны специифические особенности учетных систем Германии, Франции и США. В статье отражена тенденция сближения европейских национальных систем учета в рамках МСФО.

Ключевые слова: бухгалтерская отчетность, бухгалтерский баланс, отчет о прибылях и убытках, публичная отчетность
\end{abstract}

\section{FEATURES OF FINANCIAL STATEMENTS IN FOREIGN COUNTRIES}

Horetleva B.M., Mirsova S.G. student, Adyghe state university, Maykop Research supervisor: Vodozhdokova Z.A. Cand.Econ.Sci., associate professor, Adyghe state university, Maykop

\begin{abstract}
The article summarizes the international experience of the financial statements of entities listed specific features of accounting systems of Germany, France and the United States. The article reflects the trend of convergence of European national accounting systems under IFRS. Keywords: financial statements, balance sheet, profit and loss statement, public reporting
\end{abstract}

С недавних пор тенденцией, имеющей первостепенное значение, стала гармонизация бухгалтерского учета. Она подразумевает распространение знаний и успехов одних стран в практике составления финансовой отчетности других на основе Международных стандартов финансово й отчетности. Исследование практики ведения бухгалтерского учета за рубежом позволяет улучшить национальную систему учета. В процессе исследования выявляется большой список правил и принципов ведения бухгалтерского учета, поэтому целесообразно выбрать лишь то лучшее, что впоследствии можно применить в национальных условиях.

Состояние национальных систем
бухгалтерского учета и отчетности той или иной страны зависят от уровня экономического развития, а также исторических традиций этой страны. Поэтому экономически развитые страны отличаются самым высоким уровнем развития системы учета и финансовой отчетности. [3]

В соответствии с Концептуальным и основами США финансовая отчетность информирует реальных и потенциальных инвесторов, кредиторов, а также других пользователей. Полученная информация необходима, чтобы принять рациональные инвестиционные, кредитные и другие решения. Термин «другие пользователи» означает сотрудников и клиентов компании, государственные органы и общество в целом. В Америке «другие пользователи» считаются второстепенным и пользователями финансовой отчетности. Во-первых, это связано с тем, что эта категория пользователей не принимает такие важные решения, как приобретение или продажа ценных бумаг компании; они не участвуют в согласовании условий кредитования компании. Во-вторых, цели предоставления финансовых отчетов для работников и клиентов компании, а также общества невозможно четко определить. 
Такая ситуация типична и для других стран англо-американской системы учета [1].

В европейских странах наблюдается другая картина. Так, во Франции с 1977 года действует закон, в соответствии с которым крупные французские компании обязаны раз в год представлять советам работников, так называемый «общественный (социальный) баланс». Показателями баланса являются движение персонала по категориям, заработная плата и социальные отчисления, охрана труда, подготовка персонала, условия жизни персонала и др. Схожий подход к предоставлению такой информации применяют и другие страны Европы, такие, как Германия и Скандинавские страны. В Англии руководство компании имеет выбор: раскрывать данную информацию работникам или нет, а также самостоятельно решает в какой форме. Аналогичная ситуация характерна для Австралии и Новой Зеландии [3].

Нормативные акты развитых стран уделяют особое внимание регламентации состава и содержания финансовой отчетности. Законодательство разрабатывает перечень обязательных статей для компаний любого размера. Вдобавок, компаниям разрешено применять дополнительные статьи, если известно, что пользователи отчетности нуждаются в раскрытии этой информации. Как показывает практика, во многих зарубежных странах публикация отчетности компаний способствует поддержанию имиджа их деловой активности. В результате непрерывного анализа показателей отчетности определяются рыночные курсы ценных бумаг, а сами компании выбирают платежеспособных партнеров.

Таблица 1 - Сравнительный анализ финансовой отчетности в зарубежных странах

\begin{tabular}{|l|c|c|c|c|c|c|}
\hline \multicolumn{1}{|c|}{ Формы отчетности } & США & Англия & Франция & Германия & Испания & Италия \\
\hline Балансовый отчет & + & + & + & + & + & + \\
\hline $\begin{array}{l}\text { Отчет о прибылях и } \\
\text { убытках }\end{array}$ & + & + & + & + & + & + \\
\hline $\begin{array}{l}\text { Отчет о накопленной } \\
\text { нераспределенной } \\
\text { прибыли }\end{array}$ & + & - & - & - & - & - \\
\hline $\begin{array}{l}\text { Отчет о движениях } \\
\text { денежных средств }\end{array}$ & + & - & + & - & - & - \\
\hline $\begin{array}{l}\text { Отчет об изменениях в } \\
\text { собственном капитале }\end{array}$ & + & - & + & - & - & - \\
\hline $\begin{array}{l}\text { Пояснительные записки к } \\
\text { отчетам (комментарии) }\end{array}$ & + & + & + & + & + & + \\
\hline Отчет руководителя & - & + & + & + & + & - \\
\hline $\begin{array}{l}\text { Отчет об использовании } \\
\text { прибыли }\end{array}$ & - & - & + & - & - & - \\
\hline
\end{tabular}

В состав финансовой американских компаний включаются следующие виды отчетов: баланс, отчет о финансовых результатах (отчет о прибылях и убытках), отчет отчетности нераспределенной прибыли; отчет о движении денежных средств, отчет об изменениях в собственном капитале, пояснительная записка, заключение аудиторской фирмы. 
В Америке существенным считается не формат предоставляемых отчетов, а объем информации, подлежащий раскрытию. Если компания сочтет это нужным, то она может полностью поменять форму предоставления отчетности. Ориентация отчетности на предоставление полезной информации, в сочетании со свободой в определении действительного характера раскрытия информации, приводит к тому, что раскрывается информация, связанная с принятием наиболее эффективного решения, т.е. релевантная, а аналитичность отчетов оказывается выше в силу отсутствия несущественной информации [1].

В финансовую отчетность Англии входят следующие документы: отчет о прибылях и убытках; балансовый отчет, подписанный директором; заключение аудитора, подписанное аудитором; отчет директора, подписанный должностным лицом компании; примечания к отчетности; сводный отчет.

Правила составления отчетности для французских компаний направлены на то, чтобы формировать входную информацию для национальной системы учета, с помощью которой государство контролирует экономику. Отчетность состоит из баланса, отчет о финансовых результатах, отчета о движении денежных средств (рекомендуется, но многие компании его не составляют), отчет об использовании прибыли, отчет руководителя, пояснения.

Публикуемая

отчетность акционерных обществ включает также отчет об изменениях в капитале. Обязательным является представление полугодовой отчетности акционерными обществами фондовой бирже и квартальной отчетности по продажам всеми компаниям и.

Для малых и средних французских компаний применяется сокращенная отчетность.

Статьи оборотного капитала довольно нередко классифицируются на две группы: ценности в наличии и ценности, подлежащие реализации. Первая группа включает средства в банке и кассах, тогда как вторая включает в себя сырье, материалы, незавершенное производство, готовые продукцию, задолженность дебиторов и ценные бумаги. В балансе многих организаций вторая группа (ценности в реализации) может быть поделена на две подгрупाы: ценности в эксплуатации и ценности, которые реализовываются в краткосрочный период. Ценности в эксплуатации включают материалы, сырье, готовые изделия, незавершенное производство, а ценности, реализуемые в короткие сроки - дебиторов и ценные бумаги.

В Германии в полный перечень документов, составляющих годовую отчетность, входят: баланс, отчет о прибылях и убытках, пояснительная записка, a также отчет руководства о состоянии компании и перспективах еe развития. Последний упомянутый документ представляет собой описание руководством компании основных внешних и внутренних фактов, которые повлияли на развитие компании в отчетном году. Кроме того в нем должны содержаться перспективы развития организации в обозримом будущем.

Годовая отчетность средних и крупных компании подлежит обязательной аудиторской проверке, осуществляемой независимыми аудиторами.

Финансовая отчетность Испании также состоит из баланса, отчета о прибылях и убытках, пояснительных записок к ним и отчета руководителя.

Информация, содержащаяся в сокращенном балансовом отчете, группируется в два раздела: актив и пассив. При осуществлении анализа актива, представляется возможность получить информацию о суммах основного и оборотного капитала, расходах на 
предваритель ную

оплату

краткосрочных

обязательствах

организации

и

Т.Д.

Проанализ ировав пассив, можно узнать сумму собственного капитала, отсроченной прибыли и резерва на непредвиденные ситуации и платежи, a также сумму долгосрочных обязательств организации [2].

Отчет о прибылях и убытках содержит информацию о совокупном доходе от основных видов деятельности, обычных финансовых операциях, о чрезвычайных операциях, и о результатах после уплаты налого [1].

Так же как и в Германии обязательной аудиторской проверке подлежат крупные и средние компании. К таковым относятся организации, которые не могут формировать сокращенный баланс и обязаны составлять его в полном объеме.

$\mathrm{B}$

Испании

организации, зарегистрированные на фондовой бирже, обязаны составлять сводную бухгалтерскую отчетность ежеквартально.

Бухгалтерские отчетные документы Италии включают в себя баланс, отчет о прибылях и убытках и комментарии к этим отчетам. Однако предоставлять их в полном объеме должны только крупные компании. Мелкие и средние же могут

ограничиться сокращенными вариантами.

В Италии балансовый отчет представляется горизонтально и аналогичен балансовому отчету, принятому в Германии. Отчет о прибылях и убытках составляется в вертикальном виде. Составной частью бухгалтерских отчетов являются комментарии.

Кроме указанных отчетных форм, финансовая отчетность зарубежных организаций большинства государств включает также подробные расшифровки практически по каждому бухгалтерскому счету, расчет и анализ важнейших
Экономических

показателей

работы

компании, основные инвестиционные проекты, которые предполагается осуществить в будущем отчетном периоде, а также другую важную информацию, которая может оказаться необходимой пользователям для всесторонней объективной оценки результатов работы компании в прошлом и для надежного прогноза эффективности его хозяйственной деятельности в будущем.

В некоторых странах бухгалтерская $\begin{array}{llll}\text { отчетность включает } & \text { отчет }\end{array}$ нераспределенно й прибыли, в котором детально отображаются направления ее использования на протяжении отчетного периода. Такой отчет, в частности, включен в состав финансовой отчетности американских компаний. Публикация отчета о нераспределенной прибыли дает возможность акционерам оценить состояние компании с точки зрения выплаты дивидендов, так как прибыль считается собственностью акционеров и возрастает от присоединения чистой прибыли или при аннулировании резервов, начисленных раньше из чистой прибыли.

Многие компании представляют, кроме финансовых отчетов, дополнительные отчеты, такие, как экономические отчеты, отчеты о добавленной стоимости, особенно в тех областях, где существенными являются экологические факторы и где работники считаются важной группой пользователей. Компании поощряются к предоставлению таких дополнительных отчетов, если руководство считает, что они помогут пользователям в принятии экономических решений.

Публичная финансовая отчетность, которая публикуется зарубежными компаниями, в особенности западными, иногда представляет собой ярко оформленные буклеты, которые, кроме самих форм бухгалтерских отчетов, 
заверенных аудитором, содержат много другой информации. Как правило, это обращения президента компании к акционерам, отчет совета директоров, анализ развития компании за предыдущие периоды, прогноз на ближайшие годы, описание размещения и размеров инвестиций, международных связей, информация о социальной политике компании с разными графиками, схемами, диаграммами, фотографиями и т.п. Такая информация не регулируется, а п педоставляется исключительно по усмотрению компании. Но именно она очень важна для пользователей как дополнительный источник данных для принятия решений [4].

Следовательно, каждая страна имеет свои особенности в порядке составления и представления финансовой отчетности.
Однако существует единый для всех комплект обязательных отчетов - это баланс, отчет о прибыли и убытках и примечания к ним. В большинстве случаев регламентируются лишь наиболее существенные элементы отчетов. А такие вопросы, как объем и сущность детализации отчета, включение в него специфической для данной компании информации, расчеты разнообразных показателей, отдаются на усмотрение самой компании. Но примечания в зарубежной практике учета являются основным источником информации о компании для внешних пользователей, в которых раскрывается вся существенная информация, которая повлияла на текущий финансовый результат и финансовое состояние, а также та, которая, как можно ожидать, повлияет на будущие события.

\section{ЛИТЕРАТУРА}

1.Баранов, А.В. Сравнительная характеристика формирования показателей отчетности о прибылях и убытках в отечественной зарубежной практике / А.В. Баранов, A.Е. Жминько // [Электронный peсурс]. - Режим доступа: http://finbuh.ru/text/108509-1.html.

2. Швецова, О. В. Сравнительная характеристика российских и зарубежных подходов к формированию информации о финансовых результатах в отчетности // Аудит и финансовый анализ, 2013. № 4.- С. 101-104.

3. Давыдова, В.В. Анализ финансовой отчетности: учебное пособие, изд. 2-ое исп. и доп. / В.В. Давыдова, Е.Г. Москалева, О.Р. Пронина, Л.А. Челмакина // - Саранск: Изд-во Мордовского ун-та. - 2011. - 176 с.

4. Манин, Н.В. Зарубежный опыт учета и анализа финансовых результатов организации / Н.В. Манин, М.О. Николаева // Молодой ученый, 2016. №6. - С. 498-501. 


\title{
НЕКОТОРЫЕ АСПЕКТЫ БУХГАЛТЕРСКОЙ ОТЧЕТНОСТИ МАЛЫХ ФОРМ БИЗНЕСА В ЗАРУБЕЖНОЙ ПРАКТИКЕ
}

Хоретлева Б.М., Мирзова С.Г. студентка, Адыгейский государственный университет, г. Майкоп Научный руководитель: Водождокова 3.А. к.э.н., доиент, Адыгейский государственный университет, г. Майкоп

\begin{abstract}
Аннотация: B статье рассмотрены особенности составления финансовой отчетности на мальхх и средних предприятиях во Франции, США, Италии, Испании. В статье определеньл критерии отнесения экономических субъектов к малому и среднему бизнесу в этих странах. Произведено сравнение состава отчетности мальх предприятий по странам. Ключевые слова: бухгалтерский учет, зарубежный опыт, малый бизнес, сокращенная финансовая отчетность.
\end{abstract}

\section{SOME ASPECTS OF ACCOUNTING REPORTS OF SMALL FORMS OF BUSINESS IN FOREIGN PRACTICE}

Horetleva B.M., Mirsova S.G. student, Adyghe state university, Maykop Research supervisor: Vodozhdokova Z.A. Cand.Econ.Sci., associate professor, Adyghe state university, Maykop

\begin{abstract}
The article describes the features of the financial reporting in small and medium-sized enterprises in France, USA, Italy, Spain. The article defines the criteria for classifying economic entities to small and medium-sized businesses in these countries. The comparison of the composition of small businesses reporting by countries.

Keywords: accounting, foreign experience, small business, condensed financial statements.
\end{abstract}

Динамично развивающийся сектор малого и среднего предпринимательства (далее сектор МСП), с одной стороны, - символ свободной конкуренции, который вносит заметный вклад в устойчивый экономический рост государства, а с другой - подтверждение успешной политики страны по созданию комфортных условий для ведения бизнеса.

Для успешной деятельности малых предприятий требуется полная, достоверная и своевременно поступающая учетная информация. Бухгалтерский учет на предприятия х малого бизнеса непрерывно рационализ ируется, одновременно подстраиваясь под нестабиль ную экономическую коньюнктуру.

Для проведения исследования были отобраны следующие страны: Франция , США, Италия, Испания. Во Франции 
- валюта баланса без учета накопленных убытков составляет не более 4840 тыс. евро;

- выручки за год представляет собой сумму, которая не превышает 9680 тыс. евро;

- среднесписочная

численность

сотрудников за год не превышает 50 человек.

Организация относится к разряду средних компаний в случае, если:

- валюта баланса без учета накопленных убытков составляет не более 19250 тыс. евро;

- выручка за год представляет собой сумму, которая не превышает 38500 тыс. евро;

\section{- среднесписочная}

численнос ть

сотрудников за год не превышает 250 человек [1].

Если показатели организации превышают соответствующие показатели средней компаний, она относится к разряду крупных.

Малые компании обладают рядом послаблений в предоставлении финансово й отчетности. Так, организация, относящаяся к разряду малых компаний, может публиковать отчетность в сокращенном виде и не предоставлять ее подробную детализацию. В частности, она не обязана перечислять крупных дебиторов и кредиторов, составлять пояснительную записку. Кроме того, она освобождена от формирования отчета о движении основных средств, отчета о движениях денежных средств и отчета об основных результатах и перспектив ах деятельности.

США считаются одной из самых экономически развитых стран в мире. Важным элементом экономики США является развитый сектор МСП. Среди всех фирм, действующих на территории Соединенных Штатов, 99\% составляют малые и средние предприятия. Важно отметить, что в Соединенных Штатах нет дифференциации на малые и средние предприятия: они объединены в одну группу - малый бизнес (Small Business). Количественным критерием отнесения предприятй производственных и добывающих отраслей к малому бизнесу является среднее число работников, которое не должно превышать 500 чел [1].

Сравнительная характерис тика бухгалтерской отчетности разных стран приведена в таблице 1.

\section{Таблица 1 - Сравнение состава бухгалтерской отчетности для малых и средних} предприятий разных стран

\begin{tabular}{|l|c|c|c|c|c|}
\hline $\begin{array}{c}\text { Состав бухгалтерской } \\
\text { отчетности для малых и } \\
\text { средних предприятий }\end{array}$ & Германия & Испания & Россия & Италия & США \\
\hline 1.Бухгалтерский баланс & + & + & + & + & + \\
\hline $\begin{array}{l}\text {.Отчет о финансовых } \\
\text { результатах }\end{array}$ & - & + & + & + & + \\
\hline $\begin{array}{l}\text { 3. Отчет о движении } \\
\text { денежных средств }\end{array}$ & - & - & + & - & + \\
\hline $\begin{array}{l}\text { 4.Отчет об изменениях } \\
\text { капитала }\end{array}$ & - & - & - & - & + \\
\hline $\begin{array}{l}\text { 5.Пояснительная } \\
\text { записка }\end{array}$ & - & + & - & + & + \\
\hline
\end{tabular}


В Испании допускается составление сокращенного балансового отчета в случае если:

- общий объем активов не превышает 1млн. 382 тыс. евро;

- общий объем реализации не превышает 2 млн. 884 тыс. евро;

— количество работников не превышает 50 человек [1].

Информация, содержащаяся в сокращенном балансовом отчете, группируется в два раздела: актив и пассив. При осуществлении анализа актива представляется возможность получить информацию о суммах основного и оборотного капитала, расходах на предварительную оплату, краткосрочных обязательствах организации и т.д. Проанализировав пассив, можно узнать сумму собственного капитала, отсроченной прибыли и резерва на непредвиденные ситуации и платежи, а также сумму долгосрочных обязательств организации.

Также возможно составление сокращенного варианта отчета о прибылях и убытках, если показатели организации удовлетворяют следующим критериям:

- общий объем активов не превышает 5 млн. 529 тыс. евро;

- общий объем реализации не превышает 11 млн. 539 тыс. евро;

— количество работников не превышает 250 человек.

Отчет о прибылях и убытках содержит информацию о совокупном доходе от основных видов деятельности, обычных финансовых операциях, о чрезвычайных операциях, и о результатах после уплаты налогов.

Часто организации оказываются в таких ситуациях, когда нужно подавать и полный балансовый отчет, и комментарии, и сокращенную форму о прибылях и убытках. В таких случаях структура обеих форм одинакова. Разница заключается лишь только в объеме предоставляемых сведений и степени их детализации.

В Италии бухгалтерские отчетные документы предоставлять в полном объеме должны только крупные компании. Мелкие и средние же могут ограничиться сокращенными вариантами. К крупным организациям относятся компании, показатели деятельности которых превосходят два из трех установленных ограничений:

— общий объем активов - 1 млн. 92 тыс. дол.;

— общий объем реализации -2 млн. 184 тыс. дол.;

- среднесписочная численность работников - 50 человек.

Подведем итоги проведенного исследования.

1. В развитых странах система отнесения экономических субъектов к малому и среднему бизнесу основывается на сочетании количественных (численность наемных работников, общая годовая выручка, общая стоимость активов или валюта баланса) и качественных (структура собственности, вид деятельности и др.) критериев. Но значения этих критериев в разных странах сильно различаются, поэтому можно сделать вывод о несопоставимости общих экономических показателей развития малого и среднего бизнеса в международном масштабе.

2. На сегодняшний день все больше стран, составляя учетные стандарты для экономических субъектов, учитывают размер бизнеса, такая дифференциация получила еще большее распространение с вступлением в силу МСФО для малых и средних предприятий. Многие государства устанавливают автономные стандарты учета и отчетности для отдельных групп экономических субъектов, содержащие упрощенные требования к порядку формирования информации в рамках системы 
бухгалтерского учета. Такой подход позволяет компаниям, на которые ориентированы указанные стандарты, значительно сократить издержки на осуществление своей управленческой деятельности.

3. Ведение бухгалтерского учета для малых предприятий в проанализированных странах является обязательным.
4. Результаты проведенного исследования могут быть учтены при разработке и внедрении упрощенных правил бухгалтерского учета и отчетности малых и средних предприятий как одной из мер государственной политики по поддержке малого и среднего бизнеса в Российской Федерации [1].

\section{ЛИТЕРАТУРА}

1.Вершинина, А.П. Малый бизнес: критерии отнесения и классификация // Вестник Волжского университета им. В.Н. Татищева, 2014. № 2. - С. 76-85.

2. Ионова, Т. Основы бухгалтерского учета и отчетности в Германии // Сборник статей о праве Германии, 2015. Выпуск № 1. - С. 237-255.

3. Козменкова, С.В. Упрощенные правила бухгалтерского учета и отчетности для малых и средних предприятий в в / Е.С Крупинова, С.В. Козменкова // Международный бухгалтерский учет, 2015. №40 (382) - C.72-74.

4. Артюхова, К.Ю. Особенности бухгалтерского учета субъектов малого бизнеса на основе анализа РСБУ/ К.Ю. Артюхова, Т.А. Силина // Экономика: актуальные проблемы исследований на современном этапе, 2016. - С. 45-49.

5. Водождокова, 3.А. Методика анализа финансовой отчетности субъектов малого бизнеса / 3.А. Водождокова, А. А. Емыкова // Проблемы и перспективы социально-экономического развития регионов Юга России: сборник научных трудов по материалам I Всероссийской научно-практической конференции. Майкоп: Изд-во АГУ, 2014 - C.119-124.

6. Водождокова 3.А. Проблемы анализа финансового состояния организаций малого бизнеса // Проблемы и перспективы социально-экономического развития регионов Юга России: сборник научных трудов по материалам II Всероссийской научно -практической конференции. - Майкоп: АГУ, 2015 - С.197-199. 


\section{РАЗДЕЛ IV}

\section{АКТУАЛЬНЫЕ ВОПРОСЫ ЭКОНОМИЧЕСКОЙ ТЕОРИИ}




\title{
ОСНОВНЫЕ ПРИНЦИПЫ, НАПРАВЛЕНИЯ И ИМПЕРАТИВЫ ИСПОЛЬЗОВАНИЯ
} МЕХАНИЗМА ГОСУДАРСТВЕННО-ЧАСТНОГО ПАРТНЕРСТВА НА МЕЗОУРОВНЕ

Пииканокова Н. И.

кандидат экономических наук, профессор,
Адыгейский государственный университет, г. Майкоп

Шалатов В. В.

кандидат экономических наук, дочент, Адыгейский государственный университет, г. Майкоп

\begin{abstract}
Аннотация: в статье представлен авторский подход к определению содержания и систематизации основных принщипов, направлений и императив использования механизма государственно-частного партнерства на мезоуровне.

Ключевые слова: принщип, императив, механизм государственно-частного партнерства, мезоуровень.
\end{abstract}

\section{THE MAIN PRINCIPLES, DIRECTIONS AND IMPERATIVES OF USING THE MECHANISM OF PUBLIC-PRIVATE PARTNERSHIPS AT THE MESO-LEVEL}

Pshikanokova N. I. Candidate of Economic Sciences, Professor,

Adyghe State University, Maikop

Shalatov $V . V$.

Candidate of Economic Sciences, Associate Professor,

Adyghe State University, Maikop

\begin{abstract}
: the article presents the author's approach to the definition of the content and systematize the main principles, directions and the imperative of using the mechanism of public-private partnerships at the meso-level.

Keywords: principle, imperative, the mechanism of public-private partnerships, meso-level.
\end{abstract}

В условиях, когда на федеральном уровне еще не полностью сформирована законодательная, нормативная использования методическая база партнерства, государственно-частного формировании принципов и императив применения такого механизма принадлежит региональным органам государственной власти.

Целью государственно-частного партнерства в регионах Российской Федерации является объединение материально-про изводственных, финансовых и организационных ресурсов, находящихся в их собственности, а также привлечение финансовых средств и других ресурсов из внебюджетных источников для реализации общественно значимых проектов и программ в экономике, социальной сфере, природоохранной деятельности.

Реализация механизма государственночастного партнерства в регионах может положительно повлиять на:

- масштабы и объемы частных инвестицүий для реализации общественно значимых проектов и программ;

- эффективность использования имущзества и организационных ресурсов, находямегося в региональной собственности;

- эффективность использования средств региональных бюджетов; 
- развитие инновационной экономики, техническое и технологчческое развитие общественно значимых сфер, отраслей и отдельных производств в регионах;

- повышение уровня занятости, повышение уровня и качества жизни населения в регионаx.

Участие в реализации общественно значимых проектов и программ, с использованием механизма государственночастного партнерства, регионов и хозяйствующих субъектов, независимо от масштаба и вида их деятельности, должно основываться на определенных принципах:

1) принцип законности - соблюдение прав и законных интересов сторон, участвующих в реализации общественно значимых проектов и программ, с использованием механизма государственно-частного партнерства;

2) принцип равноправия сторон - равные условия участия в реализации общественно значимых проектов и программ, с использованием механизма государственночастного партнерства, обеспечивающие конкурентную среду;

3) принцип добросовестного и взаимовыгодного сотрудничества сторон в реализации общественно значимых проектов и программ, с использованием механизма государственно-частного партнерства;

4) принцип эффективности реализации общественно значимых проектов и программ, с использованием механизма государственночастного партнерства;

5) принцип консолидация материально производственных, финансовых и организационных ресурсов сторон для реализации общественно значимых проектов и программ, с использованием механизма государственно-частного партнерства;

6) принцип разделения ответственности, рисков и достигнутых финансовоэкономических, социальных и других результатов между сторонами, участвующим и в реализации общественно значимых проектов и программ, с использованием механизма государственно-частного партнерства;

7) принцип транспарентности деятельности сторон, участвующих в реализации общественно значимых проектов и программ, с использованием механизма государственно частного партнерства.

Общественно значимые проекты и программы, реализация которых на мезоуровне, осуществляется на основе соглашений (договоров) о государственно частном партнерстве между регионами и частным бизнесом, могут быть направлены на развитие:

- транспорта и транспортной инфраструктуры;

- жилищного строительства и жилищунокоммунального хозяйства;

- системы энергоснабжения, включая энергогенерирующие системы и системы передачи и трансформачии энергии;

- гидротехнической и природоохранной инфраструктуры;

- систем связи, телекоммуникаций, сети Интернет и локальных компьютерных сетей;

- сферы обшественного сектора;

- сельскохозяйственного производства, переработки, хранения, мелкооптовой и оптовой торговли сельскохозяйственной продукцุией.

В то же время государственная поддержка расширения сферы использования механизма государственно-частного партнерства в регионах может осуществляться с учетом преференций фискального и монетарного характера.

Для эффективного использования механизма государственно-частного партнерства на мезоуровне необходимо формирование его внутренней структуры, институализация ее 
отдельных элементов.

\section{Внутренняя структура механизма}

государственно-частного партнерства в регионах в контексте рассматриваемой проблемы должна опираться на ряд императив:

- организацуионно-управленческий - должен быть создан специальный орган регионального государственного управления механизмом государственно-частного партнерства, для обеспечения его эффективного функционирования;

- инвестициионно-финансовыц̆ - в механизм государственно-частного партнерств а должны быть встроены инвестиционные и финансовые институты, обслуживающие инвестиционные и финансовые потоки, возникающие как внутри, так и между контуром механизма государственно-частного партнерства и внешней, по отношению к нему, средой. В мировой практике имеются разнообразные схемы подключения к осуществлению проектов и программ государственно-частного партнерства различных страховых компаний, государственных и частных инвестиционных фондов и т. п. Они отработаны в международных финансовых организациях, таких, как, например, Всемирный банк, Европейский банк реконструкции и развития, Азиатский банк инфраструктурных инвестиций и др.;

- системно-интеграционныц - в механизме государственно-частного партнерств а должны быть представлены структуры, выполняющие функции системного интегратора при разработке и реализации общественно значимых проектов и программ, предполагающих вовлечение нескольких государственных органов власти. Это могут быть, отбираемые на конкурсной основе, негосударственные коммерческие организации, ясно представляющие свою социальную миссию и обладающие многолетним опытом успешного взаимодействия с государственными структурами в разработке и реализации общественно значимых проектов и программ;

- консалтинговый (консультативного обеспечения) - в механизме государственно-частного партнерства должна быть максимально широко представлена региональная сеть консалтинговых и экспертных организаций, обеспечивающих независимую оценку и обоснованные рекомендации по выбору и применению конкретных механизмов государственно частного партнерства при реализации тех или иных общественно значимых проектов и программ, а также их правовое обоснование и сопровождение;

- информацчионно-коммуникацчионный - в механизм государственно-частного партнерства на региональном уровне должна быть включена, специально созданная, справочная информацио нно-коммуникацио нная сеть, для обслуживания общественно значимых и других проектов и программ государственночастного партнерства и обеспечивающая формирование привлекательного имиджа этих проектов в соответствии с их социальной значимостью и степенью воздействия на общественные интересы. Эта система может включать, например, в открытом доступе электронную базу нормативных правовых актов и данных по проектам и программам государственно-частного партнерства, находящимся на различных стадиях реализации, систему мониторинга и информационного сопровождения хода реализации проектов и программ государственно-частного партнерства, открытый правовой Интернет-сайт или портал, содержащий структурированную базу нормативных правовых документов, регулирующих вопросы в сфере государственно-частного партнерства, периодическое издание, освещающее актуальные проблемы функцио ниро в ания и развития механизма государственночастного партнерства в регионе, стране и за 
рубежом, и т. д.;

- институцииональныци - представляет собой необходимость образования нового некоммерческого института (пула, клуба, ассоциации, лиги или иного подобного образования), объединяющего на началах добровольного членства частные фирмы, выступающие партнерами региональных органов власти при реализации различных общественно значимых проектов и программ;

- кадровый (обеспечения профессионально подготовленными человеческими ресурсами) - предполагает создание системы подготовки специалистов по управлению проектами и программами, реализуемыми на основе механизма государственно-частного партнерства . Для этого необходимо создать и аккредитовать в установленном порядке учебный центр дополнительного профессионального образования, либо использовать возможности региональных вузов, разработать учебные программы и курсы, системы и порядок сертификации и итоговой аттестации обучающихся и, собственно, осуществить обучение достаточного числа специалистов;

- социальныци - предполагает встраивание интересов, так называемой, «третьей стороны» государственно-частного партнерства (непосредственных потребителей товаров и услуг, производимых в рамках соответствующих проектов и программ, получателей социальных трансфертов - население региона) в его механизм.

Резюмируя вышеизложенное, отметим, что повышение эффективности реализации механизма государственно-частного партнерства на мезоуровне возможно по таким направлениям как:

1) переход от программного бюджетного финансирования к долгосрочному проектному инвестированию из внебюджетных источников программ;

2) усиление банковского контроля эффективности использования инвестиций и страхованию проектных рисков и отказ от административного контроля;

3) повышение прозрачности конкурсных процедур, что позволяет снизить уровень коррупщии;

4) оптимизация системы бюджетного финансирования на кратко и среднесрочный периоды.

\section{ЛИТЕРАТУРА}

1. Кабашкин, В. А. Государственно-частное партнерство в регионах Российской Федерации. - М.: Дело, 2010-225 с.

2. Шалатов, В. В. Использование механизма государственно-частного партнерства при реализации социально-экономических проектов на региональном и муниципаль ном уровнях // Социальная политика и социология, 2013. № 2-2 (93). - С. 116-128. 


\title{
МОНЕТАРНОЕ СТИМУЛИРОВАНИЕ ДЕЛОВОЙ АКТИВНОСТИ МАЛОГО И СРЕДНЕГО БИЗНЕСА
}

Хатков М.A. студент, Адыгейский государственный университет, г. Майкоп Научный руководитель: Гишева С.Ш., к.э.н., Адыгейский государственный университет, г. Майкоп

\begin{abstract}
Аннотация: В статье представлено монетарное стимулирование деловой активности МСБ в Российской Федерации.

Ключевые слова: Экономический рост, деловая активность, малый и средний бизнес, денежно-кредитная политика, инфлячия, ключевая ставка.
\end{abstract}

\section{MONETARY STIMULATION OF BUSINESS ACTIVITY OF SMALL AND MEDIUM BUSINESS}

Khatkov M.A.

Student, Adygea state university, Maikop Research supervisor: Gisheva Saida Shumafovna Cand.Econ.Sci., Adygea state university, Maikop

\begin{abstract}
The article describes the monetary stimulation of business activity of small and medium business in the Russian Federation.

Keywords: Economic growth, business activity, small and medium business, monetary policy, inflation, key rate.
\end{abstract}

Экономический спад, последовавший за снижением цен на сырьевые товары российского экспорта в 2014 году, и предшествующая ему затухающая экономическая динамика выявили глубокие внутренние структурные проблемы российской экономики, ее уязвимость к изменению внешних факторов и необходимость смены модели экономического развития России в целях обеспечения высоких темпов экономического роста, повышения уровня и качества жизни населения страны.

Деятельность органов государственного управления, регуляторов и всех участников экономических отношений на всех уровнях, в том числе и Банка России, будет определять тренд развития российской экономики, эффективность перехода от углеводородной к инвестиционно-инновационной модели экономического роста через формирование его генераторов и создание благоприятной среды для роста деловой активности.

Одним из генераторов российского экономического роста должен стать малый и средний бизнес (далее МСБ), долю которого необходимо увеличить в экономике (в ВВП) как минимум вдвое (с 21\% до 45-50\%) [1].

Серьезное падение настроений в малом и среднем предпринимательстве (далее МСП) наблюдалось в конще 2014 года, после чего возобновление падения наблюдалось в конце 2015 года. Последние три квартала текущего 2016 года оптимизм МСБ растет: растут темпы найма сотрудников и темпы роста заработных плат, восстановились объемы продаж на предкризисном уровне 2014 года.
Президент
«Опоры
России»

(Общероссийской общественной организации МСП) Александр Калинин обеспокоен отсутствием у бизнеса готовности к инвестициям [2].

Основной параметр цикличности развития экономики - это уровень и динамика 
инвестиционных расходов. Действительно, пока бизнес не начнет диверсифицировать и инвестировать в собственные технологии, в новую собственную продукцию, реального экономического роста не будет.

Таким образом, нужны дополнительные стимулы для расширения бизнеса, собственных производств, для роста деловой активности МСБ как детерминанты положительной экономической динамики основных макроэкономических показателей [7].

Так, Указом Президента Российской Федерации от 05.06.2015г. №287 «О мерах по дальнейшему развитию малого и среднего предпринимательства» создано Акционерное общество «Федеральная корпорация по развитию малого и среднего предпринимательства» (Корпорация МСП) в целях осуществления деятельности по развитию малого и среднего предпринимательства, координации оказания поддержки субъектам МСП.

Единственный учредитель и акционер корпорации МСП - Российская Федерация в лице Федерального агентства по управлению государственным имуществом [3].

Одной из важнейших задач Корпорации МСП является обеспечение субъектов малого и среднего предпринимательства доступным и кредитными ресурсами.

Совместно с Минэкономразвития России и Банком России Корпорация МСП разработала Программу стимулирования кредитования субъектов МСП, реализующих проекты в приоритетных отраслях, которая фиксирует процентную ставку по кредитам в сумме не менее 10 млн. рублей для субъектов:

— малого бизнеса - на уровне 10,6\% годовых;

- среднего бизнеса - 9,6\% годовых.

Предоставление таких льготных кредитов в рамках Программы значительно расширяет возможности в обеспечении доступности долгосрочного инвестиционного и оборотного кредитования для малого и среднего бизнеса при реализации в приоритетных отраслях значимых проектов: приобретение основных средств, модернизация и реконструкция производства, запуск новых проектов, а также пополнение оборотных средств.

Приоритетные отрасли в рамках Программы:

- сельское хозяйство;

- промышленность;

- строительство;

— транспорт и связь;

- высокотехнологичные проекты;

—внутренний туризм;

- производство и распределение электроэнергии, газа и воды.

Кредитные организации, предоставляющие финанс ирование предпринимателям по Программе получают возможность рефинансирования в Банке России по ставке 6,5\% годовых, поэтому Программа получила второе название «Шесть с половиной».

В программе участвуют 21 уполномоченный банк, в том числе, ПАО Сбербанк, ПАО Банк ВТБ, ПАО ВТБ 24, АО «Россельхозбанк», АО «Альфа-Банк», ПАО «Промсвязьбанк», ПАО Росбанк, АО «Райффайзенбанк».

Сбербанк резко снизил ставки по своим кредитам для МСБ. Затем «ВТБ 24» и «Промсвязьбанк» сделали то же самое. Таким образом, ситуация с доступностью денег существенно улучшается.

Также интересна совместная программа «Доступный кредит для МСП», реализуемая Фондом развития Дальнего Востока (ФРДВ) и Сбербанком. Первыми получателями стали предприниматель из Хабаровского края и компании из Камчатского края и Сахалинс ко й области. Объем первых трех одобренных кредитов составил 190 млн. рублей, 70 из 
которых предоставил ФРДВ. Процентная ставка составила от $10,4 \%$ до $12,5 \%$.

Экономика не имеет шансов на устойчивый экономический рост при высокой инфляции и стандартных ставках кредитования 13-15\%.

Основные проекты в обрабатывающей промышленности, а также научнотехнические, инфраструктурные, являются долгосрочными и не могут быстро окупиться.

Крупным предприятиям не имеет смысла брать кредиты, поскольку экономика не растет. В России отсутствуют растущие рынки, кроме сельского хозяйства, пищевой, лесной и химической промышленности.

Поэтому рентабельным и безрисковым для кредитования банки считают малый бизнес, но две трети всего объема кредитования - это торговля, так как только она может быстро окупиться, если не обанкротится при резких неблагоприятных колебаниях конъюнктуры рынка.

По нашему мнению, ЦБ РФ явно преувеличивает инфляционные риски роста потребительского кредитования: за последние два года сильно упали импорт и внешний туризм, поэтому, сейчас, увеличивая потребление, люди будут в большей степени ориентироваться на российские товары и услуги, и прежде всего, на продовольствие и внутренний туризм.

Рынок потребительского кредитования растет на 2,5\% в год, при таких темпах прироста опасаться его перегрева нельзя.

Михаил Задорнов, Президент-председатель правления банка ВТБ 24, отмечает, что если Банк России сможет удержать инфляцию на уровне $3-4 \%$ хотя бы два года, это совершенно изменит поведение и бизнеса, и населения. В этом случае произойдет очень серьезный перелом в экономических моделях [4].

Банк России нацелен, прежде всего, на обеспечение внутренней экономической стабильности как важного условия для устойчивого экономического роста и снятия социальной напряженности.

Денежно-кредитная политика Банка России в рамках стратегии таргетирования инфляции наряду с другими мерами экономической политики сгладила негативное влияние внешних шоков на функционирование российской экономики и экономических агентов.

Центральный банк России обеспечивает монетарную составляющую новой модели роста экономики через реализацию следующих направлений:

- замедление инфляции и сохранение ее на уровне до 4\%;

- стимулирование сбережений домашних хозяйств, их защита от инфляционного обесценения;

- создание условий для трансформации сбережений в инвестиции.

Совет Директоров Банка России 16 сентября 2016 года принял решение снизить ключевую ставку до $10 \%$ годовых с учетом дезинфляции и снижения адаптивных инфляционных ожиданий, но при сохранении неустойчивой экономической активности. [5].

При принятии решения о ключевой ставке Банк России оценивает риски инфляции, соответствие динамики экономики и инфляции базовому прогнозу. Поддержание достигнутого уровня ключевой ставки планируется до конца 2016 года с возможностью ее снижения в I-II квартале 2017 года.

При сохранении умеренно жесткой денежно кредитной политики годовой темп прироста потребительских цен составит около 4,5\% в сентябре 2017 года и в дальнейшем снизится до целевого уровня 4\% в конще 2017 года [6]. 
Таблица1 - Размер ключевой ставки Банка России.

\begin{tabular}{|c|c|}
\hline $\begin{array}{c}\text { Дата } \\
\text { изменения }\end{array}$ & \% годовых \\
\hline 13.09 .2013 г. & 5,5 \\
\hline 03.03 .2014 г. & 7 \\
\hline 28.04 .2014 г. & 7,5 \\
\hline 28.07 .2014 г. & 8 \\
\hline 05.11 .2014 г. & 9,5 \\
\hline 12.12 .2014 г. & 10,5 \\
\hline 16.12 .2014 г. & 17 \\
\hline 02.02 .2015 г. & 15 \\
\hline 16.03 .2015 г. & 14 \\
\hline 05.05 .2015 г. & 12,5 \\
\hline 16.06 .2015 г. & 11,5 \\
\hline 03.08 .2015 г. & 11 \\
\hline 14.06 .2016 г. & 10,5 \\
\hline 19.09 .2016 г. & 10 \\
\hline
\end{tabular}

В условиях

макроэкономической при устранении излишних административных стабилизации рост масштабности и барьеров, а также при расширении доступа к эффективности государственной поддержки кредитным ресурсам в рамках монетарного малого и среднего бизнеса, налогового и стимулирования, улучшат инвестиционный правового регулирования их деятельности, климат и повысят деловую активность МСБ.

\section{ЛИТЕРАТУРА}

1. Агентство стратегических инициатив. Инвестиционный климат в России. [Электронный ресурс]. - Режим доступа: http://www.asi.ru.

2. Россия 24. Вести - экономика. Оптимизм малого и среднего бизнеса. [Электронный peсурс]. - Режим доступа: http://www.vestifinance.ru/articles/77577.

3. Торгово-промышленные ведомости. Бизнес в России. [Электронный ресурс]. - Peжим доступа: http://old.tpp-inform.ru/regions/6295.html.

4. Макроэкономика. Понижение инфляции. [Электронный ресурс]. - Режим доступа: www.banki.ru/news/lenta/?id=9330359.

5. Банковские термины. Ключевая ставка. [Электронный ресурс]. - Режим доступа: http://www.banki.ru/wikibank/klyuche vaya_stavka/.

6. Пресс-служба Банка России. Ключевая ставка. [Электронный ресурс]. - Режим дос тупа: http://www.cbr.ru/.

7. Шелехова, Л.В. Малый бизнес как фактор стабильности экономики региона (на материалах Республики Адыгея) / Л.В.Шелехова, К.А. Минченко // сборник научных трудов по материалам II Всероссийской научно-практической конференции «Проблемы и перспективы социально-экономического развития регионов Юга России». - Майкоп: Изд-во АГУ, 2015. - С. 158-164. 


\title{
ИНФОРМАЦИОННЫЕ УСЛУГИ КАК ВАЖНЕЙШАЯ ФОРМА СЕРВИСНОЙ ДЕЯТЕЛЬНОСТИ В СОВРЕМЕННЫХ УСЛОВИЯХ
}

Шитухина Н.С.

Соискатель, Майкопский государственный технологический университет, г. Майкоп Научный руководитель: Задорожная Л.И. д.э.н., профессор, Майкопский государственный технологический университет, г. Майкоп

\begin{abstract}
Аннотация: Рассматривается сущность, специфические особенности и структура информационных услуг. Обосновываются системный характер данных услуг и их ключевая роль в современной «экономике знаний».

Ключевые слова: информачия, информационные услуги, "общество знаний», информационно-коммуникационные технологии.
\end{abstract}

\section{INFORMATIONAL SERVICES AS AN IMPORTANT FORM OF SERVICE ACTIVITY UNDER THE MODERN CONDITIONS}

Shituhina N.S.

Competitor of the Maikop, State Tehcnological University, Maikop.

The Scientifical leader Zadorozhnaya L.I.

Doktor of Economical Sciences, Professor of MaikopState Tehcnological University. Maikop.

\begin{abstract}
The essence of the specific features and the structure of informational service is under consideration. The article bases the systematical nature of these services and their sourse role in the nowdauys «knowledge of economy».

Keywords: information, informational services, «knowledge society», informational and communicational technologies.
\end{abstract}

Возрастание экономической и социальной значимости деятельности, связанной с удовлетворением запросов потребителей в разнообразной информации, является одним из ключевых проявлений процесса формирования современной информационносервисной экономики. При этом данной деятельности присущ ряд специфических особенностей, обусловленных как организацией процесса ее осуществления, так и сущностными характеристикам и информации как ключевого ресурса общественно-экономического развития.

Характеризуя информацию как
экономический ресурс, М. Ю. Днепров указывает на ряд концептуальных положений, определяющих сущность данной категории при ее анализе в современных научных исследованиях [3]:

-информация рассматривается в качестве обособленного производственного фактора; -указывается на двойственную природу информации, которая, с одной стороны выступает как фактор производства, а с другой - как особая форма капитала;

-представление информации как экономического ресурса осуществляется в рамках трудовой теории стоимости, определяющей информацию в качестве одного из составных элементов процесса труда.

Важнейшей имманентно присущей информации чертой является нехарактерная для других факторов производства способность существовать вне контекста социально-эко номических отношений. При 
этом в структуре таких факторов производства как труд и капитал всегда присутствует информационная составляющая, а в предпринимательских способностях она становится доминирующей.

Особенно ощутимо значимость информации как фактора производства проявляется в условиях постиндустриального общества, которое зачастую определяется как общество информационное. Экономические блага в его рамках начинают рассматриваться в контексте их информационной природы, а значимость обладания данными благами определяется ценностью информации, которая в них содержится.

При этом производством информации, как правило, занимаются частные лица либо компании, несущие, как и в рамках любого производственного процесса, определенные издержки. Подобное положение приводит к тому, что, если раньше существовало отношение к информации как к безвозмездно распределяемому общественному благу, то в условиях информационного общества она становится товаром, имеющем соответствующую цену, которая формируется в процессе координации спроса и предложения на рынке информационных ресурсов [6].

К числу ключевых свойств информации можно отнести ее асимметрию, причинам и которой являются разнородность, неполнота и ограниченность информации. Указанное свойство находит свое проявление как в ее дифференциации владельцем информации, так и в процессе получения потребителем информации, в связи с чем условие доступа к информационным ресурсам выступает в качестве ограничителя либо, напротив, стимула деятельности в сфере предоставления интеллектуальных услуг. Данное обстоятельство определяет возникновение и функционирование рынка, в рамках которого существует конкуренция за доступ к информационным ресурсам. С другой стороны, все более активно развивается разнообразная деятельность по поиску, сбору, анализу и предоставлению потребителям необходимой информация, получившая наименование информационных услуг.

При этом в экономической литературе отсутствует четкое общепринятое определение термина «информационные услуги», происходит его отождествление с понятиями «информационные продукты» и «информационные товары» услуги, а в большинстве распространенных классификаций видов услуг информационные услуги не выделяются в отдельную категорию.

Отметим, что в Федеральном законе «Об информации, информатизации и защите информации» информационные услуги определены в качестве услуг, ориентированных на удовлетворение информацио нных потребностей пользователей путем предоставления информацио нных продуктов [1]. По мнению И.А. Коробейникова, под данным понятием подразумевается согласованный процесс создания потребительной стоимости, сформированной в результате целевого использования информационных продуктов, ориентированный на удовлетворение информацио нных потребностей экономических субъектов [4]. К информационным потребностям при этом можно отнести потребность в информации, потребность в доступе к информации, потребность в передаче информации, потребность в самовыражении, потребность в росте образовательного уровня, потребность во взаимодействии (общении) и т.д.

Разнообразие видов информацио нных потребностей обуславливает наличие 
различных видов информационных услуг. В этой связи, в частности, А.Л. Денисова подразделяет их на производственные, профессиональные, общественные и услуги в области связи [2].

А.В. Хорошилов и С.Н. Селетков следующим образом классифицируют информацио нные услуги: доступ к базам данных (в интерактивном режиме и режиме offline); пакетный доступ к базам данных; базы данных на носителях; консультации специалистов в сфере информационных ресурсов; обучение доступу к информационным ресурсам [7].

Ю.А. Сиднева, предлагая классифициров ать информационные услуги с функционально й точки зрения, выделяет такие их функции как создание информационного продукта на заказ, распространение информационных продуктов, консультационная функция, обеспечение обмена информацией и информационного взаимодействия различных субъектов.[5].

При этом к ключевым особенностям информационных услуг можно отнести следующие характеристики: наличие тесной взаимосвязи между информационным продуктом и информационной услугой; возможность многократного предоставления; наличие удаленного доступа к информационному продукту; возможность участия посредника в процессе взаимодействия продуцента и потребителя информационных услуг. В отношении данных услуг, предоставляемых с помощью современных информацио нно-коммуникацио нных технологий, специалисты значительно расширяют вышеприведенный перечень, добавляя следующие важнейшие черты [4]:

-формализованность - производство, реализация и потребление информационной услуги предполагает выполнение формализованных операций в контексте использования соответствующего технического обеспечения и инфраструктуры; -алгоритмичность - производство и реализация информационной услуги представляет собой последовательность осуществления алгоритмов исполнения данного процесса;

-машиноориентированность - перевод процесса производства, реализации и потребления информационных услуг в виртуальную сферу с использованием различных информационных систем;

-пролонгированность во времени - воспользоваться информационной услугой можно в регламентированное для этого продолжительное время;

-сохранность результатов производства, реализации и потребления информационной услуги - результаты сохраняются в виде использованных алгоритмов, ресурсов, запросов, инфраструктурных элементов, полученных результатов;

-глобальность

потребле ния информацио нных услуг, обусловленная всеобщим характером используемой информацио нно-коммуникацио нной инфраструктуры;

-комплексность производства, реализации и потребления информационных услуг потребляя конкретную информационную услугу, потребитель получает несколько сопутствующих услуг.

Таким образом, подводя итоги проведенного анализа, можно констатировать, что дефиниция «информационная услуга» является комплексным понятием, предполагающим сочетание таких образующих его сущностных элементов как востребованная потребителем и оплачиваемая деятельность; полезная работа по преобразованию данных в информацию с целью ее последующего предоставления потребителю; деятельность по комплектованию , систематизации и изложению знаний.

При этом для современной экономики характерна тенденция к постоянно му расширению и усложнение рынка 
информационных услуг, определяющая сервисной сферы современной «экономики постоянное увеличение их удельного веса и знаний». степени значимости в структуре элементов

\section{ЛИТЕРАТУРА}

1. Федеральный закон «Об информации, информатизации и защите информации» № 149-Ф3 от 27 июля 2006 г. // Собрание законодательства Российс кой Федерации, 1995 , № 8 . - C. 609.

2. Денисова, А.Л. Концепция качества информационных услуг. - М.: Международная академия информатизации, 1998 - 95 с.

3. Днепров, М.Ю. О методологических принципах исследования категории «информационный ресурс»// Материалы Пятой межрегиональной научной конференции «Студенческая наука - экономике России». - Ставрополь, 2005. - С. 189-191.

4. Корабейников, И.Н. Информационная услуга: понятия, особенности, качества // Вестник Оренбургского государственного университета, 2015, № 8. - С. 66-72.

5. Сиднева, Ю.Е. Информационные услуги в системе экономических отношений: теоретический аспект: дис. ... канд. экон. наук. Уфа, 2001. - 22 с.

6. Симонян, Д.Ф. Асимметрия информации как фактор неустойчивости предпринимательской структуры // Наука и образование: хозя йство и экономика; предпринимательств; право и управление, 2012, №7. - С. 94-99.

7. Хорошилов, А.В. Мировые информационные ресурсы./ А.В. Хорошилов, С.Н. Селетков // - СПб.: Питер, 2004. - 176 с. 


\section{РАЗДЕЛ V}

\section{ПРОБЛЕМЫ \\ ЭКОНОМИЧЕСКОГО \\ ОБРАЗОВАНИЯ В ВЫСШЕЙ \\ ШКОЛЕ В УСЛОВИЯХ \\ ИННОВАЦИОННОГО РАЗВИТИЯ}




\title{
НЕКОТОРЫЕ АСПЕКТЫ РR-СТРАТЕГИИ ПО ПРОДВИЖЕНИЮ НА РЫНКЕ ОБРАЗОВАТЕЛЬНЫХ УСЛУГ (НА ПРИМЕРЕ ФАКУЛЬТЕТА)
}

Кочконян В.А. студентка, Адыгейский государственный университет, г. Майкоп Научный руководитель: Бюллер Е. $A$. к.э.н., доцент, Адыгейский государственный университет, г. Майкоп

\begin{abstract}
Аннотация: В статье рассмотрены возможные рг-стратегии для факультета на примере АГУ, представлены данные о количестве поступивших за предшествующие три года. Ключевые слова: паблик рилейшнз, реклама, позитивный имидж, иелевая аудитория, связь с обшественностью.
\end{abstract}

\section{SOME ASPECTS OF PR STRATEG Y FOR PROMOTION IN THE MARKET OF EDUCATIONAL SERVICES (FOR EXAMPLE DEPARTMENT)}

Kochkonyan V.A. Second year student, Adygei state university, Maykop Scientific supervisor: Buller E.A. Cand.Econ.Sci., associate professor, Adygei state university, Maikop

\begin{abstract}
The article discusses the possible pr strategy for the faculty on the example of ASU, presented data on the number received for the previous three years

Keywords: public relations, advertising, positive image, target audience, communication with the public.
\end{abstract}

Во всех сферах человеческой деятельности PR приобрел колоссальное значение. Он определяется различной степенью для каждой отрасли человека отдельно, поддерживая связь с общественностью. В большей или меньшей степени он используется практически везде: политике, бизнесе, благотворительности и т.д.

Существует множество понятий PR. Французский исследователь, теоретик и практик PR считает, что «это поведенческая мораль групाы, стратегия и технология коммуникаций, подлинное приложение гуманитарных наук, имеющих целью установление и поддержание товарищеских отношений.».

Рекс Херлоу, старейший специалист по ПР из Сан-Франциско утверждает: «ПР - это одна из функций управления, способствующая установлению и поддержанию общения, взаимопонимания , расположения и сотрудничества между организацией и ее общественностью. Они включают в себя решение различных проблем: обеспечивают руководство организации информации об общественном мнении и оказываю ему помощь в выработке ответных мер; обеспечивают деятельность руководства в интересах общественности; поддерживают его в состоянии готовности к различным переменам, путем заблаговременного предвидения тенденций; используют исследование и открытое общение в качестве основных средств деятельности» [1].

Сэм Блэк утверждал: «Паблик рилейшнз это искусство и наука достижения гармонии посредством взаимопонимания, основанного на правде и полной информированности» [2].

Анализируя большинство понятий, можно сказать, что авторы рассматривают PR как деятельность по достижению позитивного имиджа, так или иначе во всех понятиях присутствует один и тот же смысл: наука, 
искусство и коммуникативная деятельность, направленная на создание и поддержание благоприятных отношений между субъектом PR и его общественностью на основе достоверной информации.

Как ранее говорилось, PR затрагивает различные сферы человеческой деятельности. На сегодняшний день определенная часть университетов вмешательстве

для

поддержания

И

увеличения поступающих абитуриентов. С данной проблемой столкнулся экономический факультет Адыгейского государственного университета. Для наглядности представим сформулированную таблицу о количестве поступивших за три последних года (20142016 гг.).

\section{Таблица 1 - Контингент обучающихся студентов на экономическом факультете АГУ на начало учебного года.}

\begin{tabular}{|l|c|c|c|}
\hline Учебный год & 2014 гг. & 2015 гг. & $2016 г$. \\
\hline Кол-во студентов & 163 & 137 & 61 \\
\hline
\end{tabular}

По данным таблицы, видны резкие изменения в количестве поступающих и обучающихся студентов на факультет среди первых курсов. Сокращение контингента обучающихся может привести к сокращению нагрузки профессорско-преподавательс кого состава, а следовательно некоторые направления факультета могут стать нерентабельны. В дальнейшем это может привести к понижению репутации факультета.

Для избегания этого PR поможет определить целевую аудиторию. В нашем случае это будут учащиеся школьных образовательных учреждений. Факультету при решении проблемы недобора абитуриентов или с ежегодным снижением набора поступающ их необходимо формировать устойчивые связи co школьниками. Предполагается, что основной акцент стоит делать на обучающихся сельских школ, так как для городских школьников горизонты открываются в больших городах, на что возможностей и способностей у них больше.

Обучающиеся 8-11 классов не всегда правильно понимают наименование направле ния подготовки. Для того, чтобы помочь школьникам понять сущность интересующей их

специальнос ти, необходимо устраивать с ними выездные встречи, на которых целесообразно рассказать им о факультете, о выдающихся выпускниках, а также о возможных местах работы. Будет лучше, если на контакт со школьникам и пойдут сами студенты, потому что информация уже будет восприниматься проще.

Очень важна связь с общественностью, возможно у заинтересовавшейся молодежи и их родителей возникнут вопросы, требующие ответов. Здесь тоже хорошо стоит подобрать средство для общения: телефон, электронная почта, прямой контакт с представителям и ВУЗа.

Так же на факультете можно создавать кружки экономической грамотности, проводить Олимпиады для школьников. На кружке экономической грамотности могут вестись дискуссии по различным темам: «Инфляция денег», «Себестоимость продукции» «Планирование семейного бюджета» и различные другие темы, которыми будут заинтересованы школьники, данное мероприятие полезно для обучающихся средних учебных заведениях: 
- расширяется базовый уровень знаний заинтересованных в кружке;

\section{- вырабатывается}

экономическое

мышление подрастающего поколения;

- расширяется кругозор;

— обучающиеся приобретают основные элементы экономической культуры.

Это полезно для факультета не только тем, что привлекается молодежь со школьной скамьи, но и тем, что формируется экономически грамотные абитуриенты, формируется бонус к имиджу.

Так же можно проводить открытые лекции, которыми заинтересованы школьники и не только. Это могут быть обычные лекции для студентов четвертыми парами, но в определенный день с определенно выбранно й темой. О лекции разглашает факультет, если темой лекции заинтересованы школьники и студенты других факультетов, то можно проводить уже отдельные лекции, не отвлекающие студентов экономического факультета.

Очень важно заинтересовать аудиторию, чтобы о ВУЗе и факультете узнали, как можно больше. Первым делом университет дает рекламу. В условиях мощной конкуренции рекомендуется не просто реклама, а сильнодействующая рекламная компания, грамотно организованная. Реклама в прессе это самый быстрый путь привлечения абитуриентов [3]. При правильной рекламной стратегии, чем чаще реклама повторяется, тем больше она оставляет шанс быть замеченной и быстрее привлечь абитуриентов в данный ВУЗ. Привлекая новых учащихся необходимо подчеркивать выгоды, говорить о том, что они лично получат, и что даст им университет в процессе обучения. Так же факультетам и специаль ностям необходимо охарактеризовать подчеркивать выгоды, реклама должно содержать информацию о том, что эти полезные услуги им принесут. Дать основательные причины поступить в университет по данной специальности.

Данные рекламы стоит распространять как на сайтах, социальных сетях, так и публиковать в газетах, вещать на радио, телевиденье, так как не все жители являются обладателями интернета.

Рассматривая проблему острого дефицита абитуриентов, мы можем говорить о том, что на сегодняшний день PR является необходимым для достижения поставленных целей факультетом, в данном положении. Через рекламу можно поднять имидж, увеличить круг заинтересовавшихся. Говоря о связи факультета с общественностью, хочется подчеркнуть, что основной целевой аудиторией являются школьники. И в поддержке долгосрочной связи с ней хочется видеть заинтересованным не только факультет, но и сам ВУЗ, так как факультет это его одна из составляющих частей.

\section{ЛИТЕРАТУРА}

1. Волкова, А. Н. Словарь терминов для PR-специалистов. - СПб.: 2010. - 78 с.

2. Кравченко, П. PR-проекты: цели меняются, коммуникации остаются // Всероссийский специализированный журнал «Пресс-служба», 2015. №1. - С. 48.

3. Марусева, И. В. Дипломное проектирование в области PR и рекламы. - M.: 2015. $751 \mathrm{c}$. 


\section{РОЛЬ СТУДЕНТОВ ЭКОНОМИЧЕСКОГО ФАКУЛЬТЕТА АГУ В ПРОФЕССИОНАЛЬНОМ ОРИЕНТИРОВАНИИ АБИТУРИЕНТОВ}

Оганнисян М.A.

студент экономического факультета; Адыгейский государственный университет, г. Майкоп

Научный руководитель: Тамов А. А проф., д.э.н., Адыгейский государственный университет, г. Майкоп

Аннотация. В статье раскрыта роль студентов в профессиональном ориентировании студентов на примере экономического факультета Адыгейского государственного университет.

Ключевые слова: профессиональное ориентирование, абитуриент, студент, проф. ориентирование.

\section{THE ROLE OF STUDENTS OF ECONOMIC FACULTY OF ASU} PROFESSIONAL ORIENTATION OF APPLICANTS

Ogannisyan M.A. student of the Faculty of Economics; Adyghe State University, Maikop Supervisor: Tamov A.A. Doctor of Economics, professor, Adygeya State University

Abstract: The article reveals the role of students in the professional orientation of students on an example of the economic faculty of the Adygeya State University.

Keywords: vocational guidance, applicants, students, prof. orientation.

В жизни экономического факультета и факультет АГУ получал около 80 бюджетных Адыгейского государственного университета мест и почти столько же набирали на 1 курс в целом важное место всегда занимала по бакалавриату и магистратуре, то в 2016 проблема количественного и качественного году впервые количество бюджетных мет набора абитурие нтов. уменьшилось до 18 (рис. 1).

Если в последние годы экономический

Рисунок 1. Количество бюджетных мест на экономическом факультете АГУ в 2013-2016 22. 
Справедливости ради отметим, что с такой ситуацией столкнулось большинство вузов страны. Так, в 2016 году в ведущих вузах краснодарского

края

и МГТУ

по картина, отображённая на рисунке 2 .

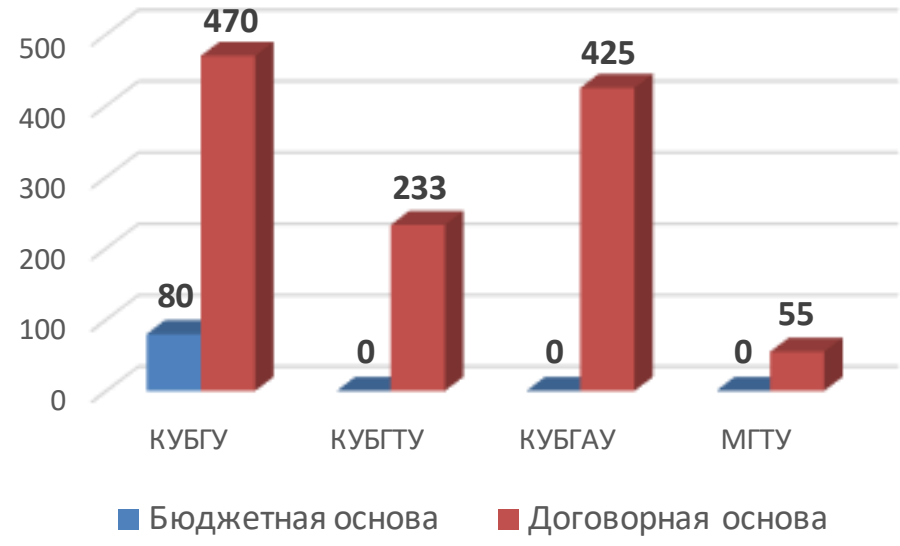

Рисунок 2. Количество бюджетных мест по экономическим специальностям в ведущичх вузах краснодарского края и МГТУ

Как видно из рисунка 2, указанные вузы Так, в Российском экономическом также испытывают сложность с набором аби- университете имени Г.В. Плеханова, ректор туриентов на экономические специальности, которого приезжал недавно в АГУ, количество ввиду малого количества бюджетных мест бюджетных мест в 2016 году составило 350 или их отсутствия. для обучения по 4 основным экономическим Есть, конечно, и противоположные примеры. направлениям (рисунок 3).

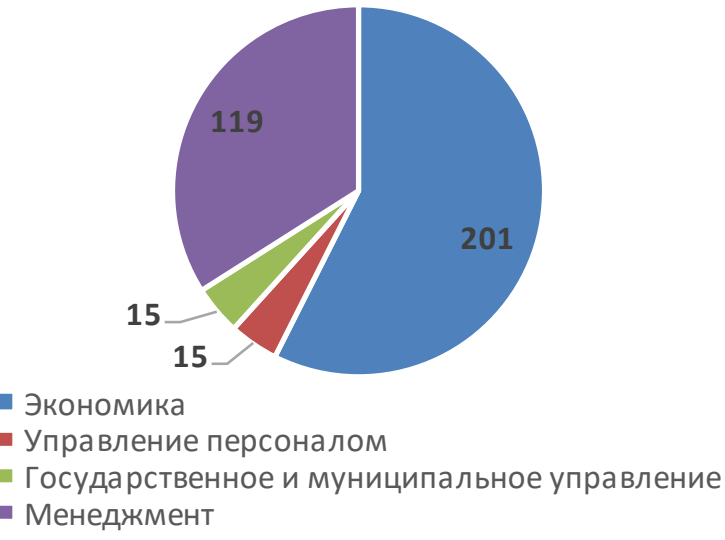

Рисунок 3. Распределение бюджетных мест по экономическим специальностям в РЭУ им. Г.В. Плеханова на 2016 год.

И хотя наш факультет набрал по очной форме обучения в текущем году все те же 80 коммерческих студентов бакалавров и магистрантов, сокращение бюджетных мест в 4 раза - это очень большая потеря. С учетом того, что на 2017 год выделено всего 20 бюджетных мест, а в последующие годы увеличения количества бюджетных мест, скорее всего, не будет, проблема коммерческого набора становится на обозримую перспективу ключевой.

Вот почему профориентационной работе было посвящено в октябре текущего года специальное заседание Ученого совета АГУ и заседание Ученого совета нашего факультета. Понятно, что в привлечении абитуриентов 
должны активно участвовать и студенты. Каждому следует внести свою посильную лепту. Причем, в рамках общего факультетского плана, где четко прописан сектор нашей ответственности.

Далее остановимся на том, что сделано нами, студентами факультета, в рамках этой работы и что предстоит еще сделать.

Прежде всего, мы оценили внешние вызовы.
Таковыми, на наш взгляд, являются перспективы дальнейшего сохранения влияния «демографической ямы» конца 90-х гг. и начала 2000-х гг,, учитывая, что в ближайшие три годак нам будут поступать те, кто родился в период с 1999 по 2001 гг., в годы наиболее сиЛьНОГО проявле ния демографической ямы (рис. 4).

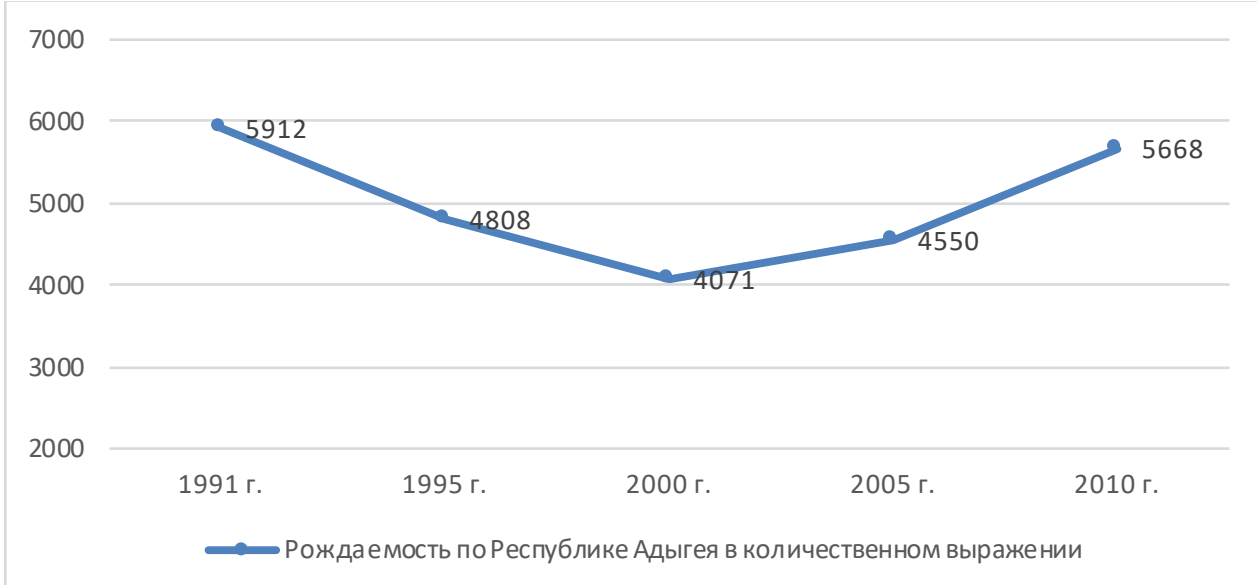

Рисунок 4. Рождаемость по Республике Адыгея в количественном выражении в период с 1991 по 201022.

Второй вызов связан с динамикой числа году.

абитуриентов, сдающих ЕГЭ по В этих условиях ключевой задачей является обществознанию. активизация работы по привлечению По данным Министерства образования внимания абитуриентов к нашему факультету. Республики Адыгея можно заметить, что До того, как они определятся с выбором тенденция сдачи ЕГЭ по обществознанию специальности и вуза, нужно довести до них неутешительна.

Как мы видим на рисунке 5, количество привлекательную и в то же время объективную информацию о факультете и абитуриентов, сдавших ЕГЭ по профильному предмету для поступления на наш факультет снизилось почти вдвое по отношению к 2014 специальностях, по которым обучаются студенты, а также о перспективах их трудоустройства.

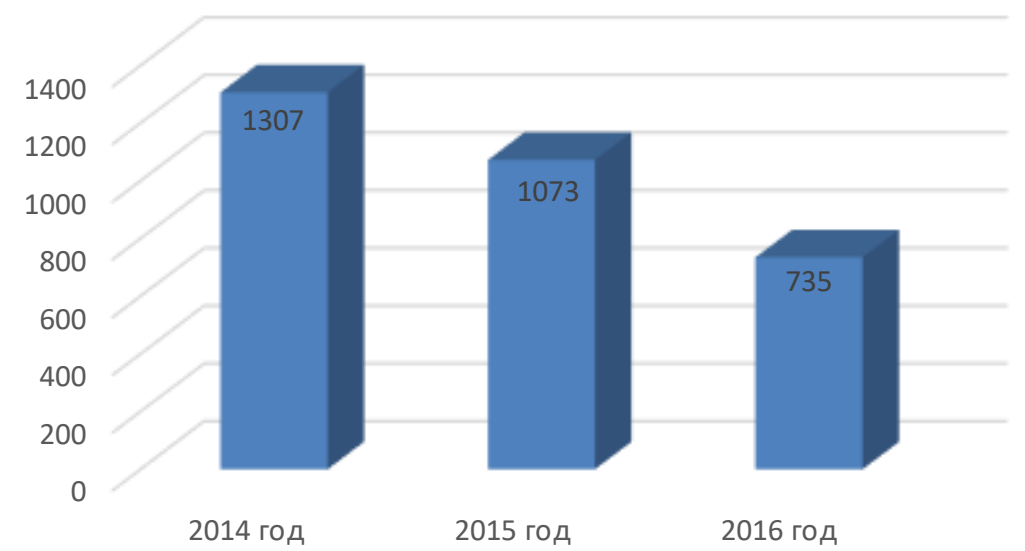

Рисунок 5. Количество выпускников, сдававщих ЕГЭ по обществознанию 2014-2016 22. 
Чтобы такая работа велась целенаправленно, на факультете студентов, охватив 70\% из них мы провели анкетирование уже обучающихся (рис. 6).

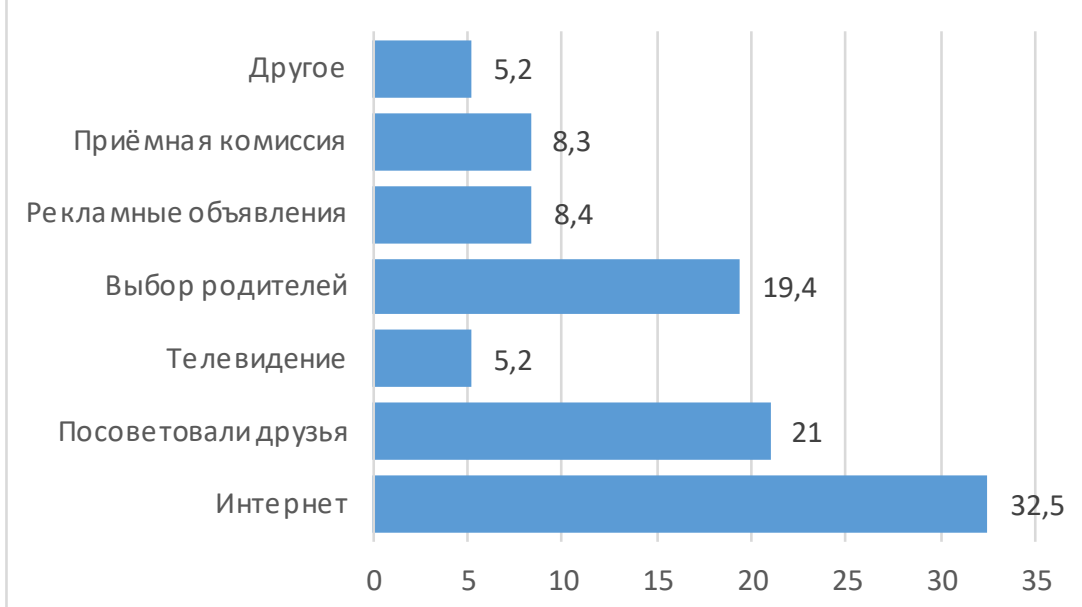

Рисунок 6. Ответы респондентов на вопрос: «Из каких источников

Вы узнали об экономическом факультете Адыгейского государственного университета? ».

Как видно из рисунка 6, большинство наших студентов, будучи абитуриентами, получали информацию о факультете из интернета. Выяснив это, мы активизировали работу в социальных сетях. В первую очередь, был сделан упор на нашу группу Vkontakte.

Месяц назад мы открыли свою страницу в Instagram, и на сегодня у нас уже более пятисот пользователей. Нами были выбраны именно эти две площадки, так как большинство абитуриентов и студентов активно ими пользуется. Для абитуриентов мы демонстрируем конкурент ные преимущества выбора экономического факультета АГУ, а для студентов публикуется новостная информация.

Ha наш взгляд, главная задача профориентационной работы состоит в том, чтобы донести до абитуриентов и их родителей главные конкурентные преимущества экономического факультета АГУ перед факультетами иных вузовконкурентов.
Среди

основных

конкурентных преимуществ можно выделить следующие:

- высокопрофессиональный преподавательский состав;

- неотъемлемым преимуществом экономического факультета Адыгейского государственного университета является новое здание, в котором есть все для организации учебного процесса на самом высоком уровне;

- наличие базовой кафедры и договоров с ведущими предприятиями и организациям и Адыгеи, где проходят практику и трудоустраиваются многие выпускники;

- наличие комфортных условий для проживания в общежитии;

- с 2017 года будут выделены 14 бюджетных мест для обучения по двум программам магистратуры;

- специальности, по которым ведётся подготовка на нашем факультете, по данным портала "Моё образование" относятся к самым престижным (рис. 7). 


\begin{tabular}{|c|c|c|}
\hline Место & Название специальности & $\begin{array}{c}\text { Рейтинговый } \\
\text { балл }\end{array}$ \\
\hline 1 & $\begin{array}{l}\text { Государственное и } \\
\frac{\text { муниципальное }}{\text { управление }}\end{array}$ & $100.0 \%$ \\
\hline 2 & Менеджмент & $98.7 \%$ \\
\hline 3 & Экономика & $77.3 \%$ \\
\hline 4 & Бизнес-информатика & $72.6 \%$ \\
\hline 5 & Юриспруденция & $71.0 \%$ \\
\hline 6 & $\begin{array}{l}\text { Реклама и связи с } \\
\underline{\text { общественностью }}\end{array}$ & $68.5 \%$ \\
\hline 7 & $\begin{array}{l}\text { Международные } \\
\text { отношения }\end{array}$ & $68.3 \%$ \\
\hline 8 & 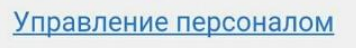 & $66.3 \%$ \\
\hline 9 & $\begin{array}{l}\text { Информатика и } \\
\text { вычислительная техника }\end{array}$ & $63.7 \%$ \\
\hline 10 & $\begin{array}{l}\text { Экономическая } \\
\underline{\text { безопасность }}\end{array}$ & $61.7 \%$ \\
\hline 11 & Гостиничное дело & $58.2 \%$ \\
\hline 12 & Лечебное дело & $58.2 \%$ \\
\hline 13 & Туризм & $57.9 \%$ \\
\hline
\end{tabular}

Рисунок 7. Данные портала «Моё образование» о рейтинге специальностей в Высших учебных заведениях.
На базе экономического факультета месяц назад была открыта школа молодого экономиста «АГУЭКОНОМ» для учащихся 10-11 классов. Слушатели школы получают углубленные знания основ современной экономической науки и необходимые навыки для успешной сдачи ЕГЭ по предмету «Обществознание» с целью поступления в лучшие вузы страны. И в первую очередь,- в АГУ, к нам на факультет.

А в целом, роль студентов факультета профессиональ ном ориентировании абитуриентов очень значима. И мы должны постараться, чтобы количество первокурсников на экономический факультет АГУ, несмотря на все сложности, из года в год только росло.

\section{ЛИТЕРАТУРА}

1. Официальный информационный портал Единного Государственного Экзамена [Электронный ресурс]. - Режим доступа: http://www.ege.edu.ru/ru/.

2. Шикина, Е.А. Особенности профессиональной ориентации выпускников школ: проблемы и решения // СЭПТП, 2012 , №6 - С.4. 
НЕТВОРКИНГ КАК СЕТЕВАЯ ФОРМА ОРГАНИЗАЦИИ ЭКОНОМИЧЕСКОГО ОБРАЗОВАНИЯ

Шелехова Л.В.

д.п.н., доиент, Адыгейский государственный университет, г. Майкоп

Глебова К.А.

студент, Адыгейский государственный университет, г. Майкоп

Аннотация: В статье рассматривается нетворкинг как один из элементов электроннообразовательной среды в вузе, в том числе показана необходимость введения нетворкинга в образовательную систему в контексте современных глобализационных изменений.

Ключевые слова: нетворкинг, эффективная коммуникачия, «деловые соииальные сети», сетевое образование

NETWORKING AS A NETWORK FORM OF ORGANIZATION OF ECONOMIC EDUCATION

Shelekhova L.V. Doctor of Pedagogy, Assistant Professor, Adyghe State University, Maikop Glebova K.A. Student, Adyghe State University, Maikop

Abstract: The article deals with networking as one of the elements of the electronic educational environment at the university, including the necessity of introduction of networking in the education system in the context of contemporary globalization changes.

Keywords: networking, effective communication, «business social networks», network education

В системе современного высшего образования происходит ряд изменений: меняются принципы управления учреждениями высшего образования, внедряются системы внутреннего контроля качества, модифицируется учебный процесс с учетом электронно-образовательной среды, которая подразумевает систему горизонтальных и вертикальных целью обеспечения доступности качества образования для всех категорий студентов, способствует развитию социальных сетей в образовании. Сеть же предоставляет необходимые ресурсы для достижения положительных результатов, позволяет их (ресурсы) эффективно распределять внутри системы.

Учитывая, что нетворкинг (net - «сеть» и work - «работа») рассматривается в научной литературе как инструмент достижения личной цели в процессе взаимодействия людей посредством социальных сетей [1]. Мы рассмотрим его в данной статье, в контексте ст. 15 Федерального закона «Об образовании в Российской Федерации» [8], как один из элементов электронно-образователь но й среды в вузе. В учебном процессе networking выступает, прежде всего, как процесс, заключающийся в поиске и поддержании отношений, в которых взаимный обмен информацией и опытом способствует развитию и достижению успеха вовлеченных в него людей, что может быть реализовано с помощью социальных сетей.

Как научное течение, нетворкинг зародился в 70-е гг. XX века в Америке. Всё началось с так называемой «теории 6 рукопожатий», которая была предложена в 1969 году американскими психологами Стэнли Милгрэмом и Джеффри Трэверсом [5]. Данная концепщия гласит, что каждый человек опосредованно знаком с любым другим 
жителем планеты через цепочку общих знакомых, в среднем состоящую из пяти человек. Уже позже данную идею развили другие ученые (Дарси Резак, Кейт Феррации) и пришли к выводу, что с помощью «сети своих контактов» можно решить практически любую свою проблему. И при этом, чем больше ваша сеть, тем, соответственно, быстрее вы сможете найти человека, который будет способен вам помочь в той или иной жизненной ситуации [10].

Идея нетворкинга предусматривает наличие сети деловых контактов, которые являются значимыми для данной профессиональ но й деятельности и могут опираться на любую из сфер общественной жизни человека. В зависимости от сложившейся ситуации нетворкинг может быть разделен на:

1) нетворкинг «small talk» (личный), так называемая легкая беседа, разговор о погоде, о еде, о спорте, о политике, о хорошей книге или фильме, о любой другой теме, которая поможет понять, что вы нравитесь друг другу [7];

2) деловой нетворкинг - это разговор, зачастую, сухой, прямолинейный только о цифpax, только о бизнесе и ничего более, считается методом, который используется для создания деловых возможностей по сетям, объединяющим единомышленников .

В настоящее время значительные перемены социальной сферы и рынка труда привели к качественному изменению требований, предъявляемых к профессиональному уровню выпускников вузов, в том числе будущих экономистов. Чтобы обладать такими качествами как успешность и востребованность, человеку необходимо иметь определенные свойства личности, отвечающие навыкам деловой коммуникации [11]. Однако практика показывает, что именно с этим процессом возникают наибольшие сложности у выпускников вузов. Данная проблема объясняется тем, что на современном этапе развития образования у студентов не формируются навыки деловой коммуникации посредством интернеттехнологий. Поэтому по завершению обучения они сталкиваются с проблемами при трудоустройстве в своем регионе, так как им сложно продемонстрировать свои навыки потенциальным работодателям через сеть. Введение же нетворкинга в образовательную систему позволит решить данную проблему, так как нетворкинг - это, прежде всего, обучение общению и умению завести круг полезных знакомств, который студент может использовать на протяжении всей его жизни.

Нетворкинг учит не только активности и умению устанавливать новые контакты, но и позволяет развить ряд других полезных качеств и навыков у обучающихся:

1) способность устанавливать и поддерживать доверительные отношения независимо от географического положения, часовых поясов и культурных особенностей (сотрудничество);

2) способность сохранять чёткую цель, ориентиры и общую систему приоритетов (конвергенция);

3) способность выстраивать работу посредством чётко определённых функций и обязанностей совместно используемых инструментов, процессов и методов (координация);
4) способность
задействовать
знания, навыки и опыт всех членов и расширять возможности команды в целом (потенциал) [3].

Большинство людей полагают, что, чем больше знакомых у тебя будет, тем эффективнее будет работать система рукопожатий. Однако это не так. Нетворкинг - это как раз та сфера, в которой большую роль играет не количество, а качество [4]. В теории нетворкинга содержится ряд советов, изучение которых поможет студенту с первых минут знакомства расположить к себе 
человека, повысить эффективность своей коммуникации, а в дальнейшем суметь удержать при себе нужное лицо посредством интернет-технологий. Например, чтобы доказать свою надежность и избежать ошибок в будущем, по мнению L. Lyncha, следует соблюдать несколько простых правил. К ним относятся:

1) выполнение обещаний и данного слова;

2) надежное и качественное исполнение работы;

3) профессионализм в своей отрасли и связанных с ней в большей или меньшей степени областях;

4) толерантность по отношению к людям, которые кажутся неприятными, оставляя открытую дверь для совместных отношений;

5) избегать лжи [4].

Внедрение нетворкинга в образовательный процесс может происходить в следующих формах:

1) проведение тренингов по нетворкингу. Контакт-тренинги получили большое распространение ввиду того, что позволяют быстро и эффективно выходить на первых лиц и лиц, принимающих решения. На данных тренингах Вы научитесь использовать технологии нетворкинга, получите весомые конкурентные преимущества. Вы сможете легко устанавливать контакты на любых деловых мероприятия х, запоминаться другим людям, вести беседу в заданном направлении, собирать информацию из проверенных источников и становиться «своим» человеком для любых профессиональных сообществ и объединений. Данные тренинги готовятся и проводятся в корпоративном формате. Размер группы для тренинга колеблется от 3 до 15 человек [9];

2) организация специализированных площадок. На специально организованное пространство по нетворкингу могут приглашаться ра- ботодатели и будущие работники, обучающиеся, с целью ознакомления, обмена визитными карточками и установления контактов;

3 ) введение как модуля (части курса). В основе обучению нетворкинга должен быть не простой обмен учебной информацией, а обмен мыслями, идеями, интересами. Только в этом случае происходит интерпретация информации.

Не так давно начало развиваться такое направление, как «деловые социальные сети», которые ориентированы именно на поиск сотрудников, работы, новых партнёров и прочих бизнес-контактов. Наиболее популярные среди них:

1) «LinkedIn» (предоставляет возможность зарегистрированным пользователям создавать и поддерживать список деловых контактов, которые могут быть приглашены как из сайта, так и извне, в случае, когда пользователь не имеет прямой связи с нужным лицом, он может быть представленным через другой контакт);

2) «Viadeo» (главная отличительная особенность данной социальной сети в том, что Viadeo стараются учитывать менталитет и деловую этику каждой отдельной европейской страны, что является очень хорошим плюсом, ведь деловые отношения в России и, например, в Китае абсолютно разные);

3) «Профессионалы.ru» (российская социальная сеть, которая во многом похожа на западный аналог LinkedIn);

4) «Мой Круг» (данная социальная сеть стоит на грани между личной и профессиональной, тут смешаны как обычный поиск друзей, так и поиск деловых партнёров);

5) «Sрооо» (сеть создана специаль но для помощи в продвижении бизнеса в интернете опытным и неопытным предпринимателям);

6) «Деловой мир» (деловая социальная сеть рунета, предназначенная для решения наиболее важных и значимых задач в менеджменте, 
маркетинге, финансах, управлении персоналом, работе и карьере).

В рамках становления деловой коммуникации будущих экономистов, активное участие в выше перечисленных сетях может стать эффективным механизмом формирования их социально профессионально й мобильности, чTO является основой для формирования успешной деловой карьеры.

В век высоких технологий экономического развития сеть начинает завоевывать особое значение в контексте экономического образование. Мануэль Кастельс, профессор социологии и президент научной комиссии открытого университета Каталонии, воспринимает сети в качестве новой социальной культуры общества: «Сеть представляет собой набор взаимосвязанных узлов. Узел является точкой, где кривая пересекает себя. Сеть не имеет центра, просто узлы [2]». «Узлы» экономических университетов во всем мире способны обеспечить углубленную подготовку высококвалифицированных экономистов для нужд международных компаний.

Ведь особенностью мощного университета являются квалифицированные специалисты для современного общества. В связи с этим, современные учебные программы для будущих экономистов имеют высокий спрос во всем мире. Сетевой компонент академических программ предоставляет студентам диплом экономиста с возможностью улучшить свои навыки, используя ресурсы нескольких организаций, занимающихся образовательной деятельностью [2].

Сетевое образование не следует отождествлять с использованием компьютерной или торговой сети, в которых сетевая идеология и основная польза заключается в снижении совокупной стоимости владения компонентом сети. Образование в сетевой форме не сводится к использованию компьютера, а связано с иным содержанием и организацией, другим методическим и кадровым обеспечением всей образовательной инфраструктуры [6]. Речь идет о качественно новой «сетевой педагогике», в настоящее время практически не разработанной и не исследованной.

Одной из основных целей нетворкинга как средства сетевого экономического образования является «содействие мобильности путем преодоления препятствий эффективному осуществлению свободного передвижения» [6]. Для этого необходимо, чтобы уровни высшего образования во всех странах были максимально сходными, а выдаваемые по результатам обучения научные степени - наиболее прозрачными и легко сопоставимыми. Это, в свою очередь, напрямую связано с введением в вузах модульной системы обучения и специального приложения к диплому.

Достоинства сетевого образования в развитии горизонтальных сетевых технологий состоят в следующем:

1) расширение мобильности студентов и преподавателей, межинституциональное сотрудничество университетов;

2) единые принципы признания результатов обучения;

3) расширение доступа к высшему образованию;

4) обеспечение успешного трудоустройства выпускников вузов за счет того, что все академические степени и другие квалификации должны быть ориентированы на общеевропейский рынок труда [6].

Образовательные сети могут стать движущей силой, которая позволит повысить ряд макро и микроэкономических показателей страны. Высококвалифицированные специалисты 
пользуются большим спросом на рынке многих стран. В данном аспекте интеллектуальная работа выступает в качестве основы для развития инновационно й национальной экономики благосостояния.

Таким образом, одним из условий эффективного внедрения сетевой формы реализации образовательного процесса является рассмотрение мотивов всех участников, вовлеченных в сетевое обучение, - у управления, администрирования, методической работы, авторской работы, преподавания и т.п.

Самой важной характеристикой будущего образования является умение работать в коллаборации, то есть такое участие в совместной работе, когда ее цели и задачи в такой же степени становятся осознанными целями и задачами участвующих в работе лиц [6]. Казалось бы, зачем университе там сотрудничать в борьбе за одного и того же студента, но сочетание конкуренщии и сотрудничество отличает лидеров системы образования. Рассмотренный опыт показал, что существует, по крайней мере, три мотива для российских университетов участвовать в реализации сетевого образования, а именно:

1) возможность сконщентрировать усилия на совершенствовании достигнутого уровня развития за счет заимствования лучших образцов друг у друга;
2) сотрудничество в конкурентных условиях порождает инновации, что может привести к более эффективным схемам организации образовательного процесса;

3) работа в сети ведет к образованию единого российского научно-образовательного пространства, что поможет интеграции России в мировые процессы.

Как мы видим, нетворкинг является основой для продвижения многосторонних отношений в различные сферы деятельности, в том числе и в области образования. Ведь в XXI веке, когда глобализация затрагивает каждый аспект человеческой жизни, создание сетей становится наиболее актуальным. Однако, не следует понимать нетворкинг слишком узко, только как организацию мероприятий и обмен информацией и документами. Нетворкинг гораздо более широкое понятие, он направле н на стимулирование процессов взаимодействия между заинтересованным и учреждениями и их сотрудниками, между партнерами по международным проектам. Нетворкинг связан с нашей способностью изучать, применять, передавать и совместно использовать знания. Навыки нетворкинга можно совершенствовать, точно так же как и многие другие личные способности, а данные усовершенствования помогут наладить связи с международным научно-техническим сообществом в будущем.

\section{ЛИТЕРАТУРА}

1. Hadfield, M. What does the existing knowledge base tell us about the impact of networking and collaboration? A review of network-based innovations in education in the UK. Nottingham / M. Hadfield, M. Jopling, C. Noden, D. O’Leary, A. Stott // - UK: National College for School Leadership, 2006 - C. 57-58.

2. Ziyatdinova, J.N. Networking in Engineering Education: Case Study of Russia and Vietnam / J.N. Ziyatdinova, A. Sukhristina // Department of Foreign Languages for Professional Communication. [Электронный peсурс]. - Режим доступа: http://www.weef2015.eu/Proceedings_WEEF2015/proceedings/papers/Contribution 1305 .pdf. 
3. Как эффективно строить коммуникации в научно-исследовательских проектах [Электронный pecypc].

Режим

доступа: http://www.iate.obninsk.ru/files/u3/3_Networking\%20skills.pdf.

4. Крутиков, В.К. Нетворкинг - креативный навык, соединяющий / В.К. Крутиков, Ю.В. Зайцев, И.Е. Ефимова, И. Цоп-Петрова // Серия «Креативная экономика», 2015, №3 - C. 44-46.

5. Нетворкинг [Электронный ресурс $] . \quad-\quad$ Режим доступа: https://ru.wikipedia.org/wiki/\%D0\%9D\%D0\%B5\%D1\%82\%D0\%B2\%D0\%BE\%D1\%80 $\% \mathrm{D} 0 \% \mathrm{BA} \% \mathrm{D} 0 \% \mathrm{~B} 8 \% \mathrm{D} 0 \% \mathrm{BD} \% \mathrm{D} 0 \% \mathrm{~B} 3$.

6. Сетевое образование: лучшие отечественные и зарубежные практики [Электронный pecypc]. - Режим доступа: http://www.science-education.ru/ru/article/view?id=10981.

7. Сила нетворкинга, или как продавать, не продавая [Электронный ресурс]. - Режим доступа: http://finance.tut.by/news515503.html.

8. Статья 15. Сетевая форма реализации образовательных программ? [Электронный ресурс]. - Режим доступа: http://sudact.ru/law/federalnyi-zakon-ot-29122012-n-273-fzob/glava-2/statia-15/.

9. Тренинг по нетворкингу и установлению контакта [Электронный ресурс]. - Режим доступа: http://vision-trainings.ru/newtrainings-networkingtraining.

10. Что такое нетворкинг? [Электронный ресурс]. - Режим доступа: http://советстуденту.pф/samorazvitie/chto-takoe-netvorking/.

11. Shelekhova, L.V. Innovative Education as a Factor of Professional Mobility Formation with the Students of Economic Specialties //Review of Europe an Studies; Vol. 7, No. 6; 2015, - P.54-60. 


\section{РАЗДЕЛ VI}

\section{ЭКОНОМИКА ТРУДА}

И УПРАВЛЕНИЕ ПЕРСОНАЛОМ 


\title{
МОТИВАЦИЯ ПЕРСОНАЛА В УСЛОВИЯХ КРИЗИСА
}

Бюллер Е.A. к.э.н., доцент, Адыгейский государственный университет, г. Майкоп

Сиюхова А.к. студентка, Адыгейский государственный университет, г. Майкоп

Чич И.В.

студентка, Адыгейский государственный университет, г. Майкоп

\begin{abstract}
Аннотация. Кризисная ситуация в эконолике грозит предприятию не только финансовыми проблемами и утратой своих позищий на рынке, но и потерей квалифицированных кадров, без которых преодолеть кризис невозможно. Удержание ключевых сотрудников одна из основных задач менеджмента компании на этапе кризиса. Однако руководители большинства российских предприятий концентрируют своё внимание на управлении производством, маркетингом, финансами, в то время как совериенствованию системы мотивации персонала уделяется недостаточное внимание. В статье рассматриваются особенности мотивации персонала в условиях кризиса, принципь и методы материальной и нематериальной мотивации, обосновывается ее важность для организации.
\end{abstract}

Ключевые слова: кризис, персонал, предприятие, мотивация, стимулирование, демотивацุия.

\section{MOTIVATION OF STAFF IN A CRISIS}

Buller E.A.

Cand. Econ. Sci., associate professor, Adygei state university, Maikop

Siyukhova A.K.

Student, Adygei state university, Maikop

Chich I.V.

Student, Adygei state university, Maikop

\begin{abstract}
The crisis in the economy threatens the company not only with financial problems and loss of its market position but also with the loss of skilled personnel, without whom it is impossible to overcome the crisis. Retention of keyemployees is one of the major challenges for the company's management during the crisis. However, leaders of the majority of Russian enterprises concentrate on the production management, marketing, finances, giving insufficient attention to the improvement of the system of staffmotivation. The article considers the features of staff motivation in time of crisis, principles and methods of material and non-material motivation, justifies its importance to the enterprise.
\end{abstract}

Keywords: crisis, staff, enterprise, motivation, promotion, demotivation.

В условиях кризиса, один из самых сложных моментов для предприятия, как потеря квалифицированных кадров, превращает процесс его преодоления практически невозможным. Вследствие этого, основной задачей менеджмента на кризисном этапе выступает удержание ключевых работников. Однако руководители большинства российских предприятий акцентируют своё внимание на управление производством, маркетингом, финансами, а не на совершенствование системы мотивации персонала.

Это обуславливается тем, что руководители ошибочно полагают, что в кризисное время проблем с мотивацией и эффективной 
работой персонала не должно возникать, так как сотрудники, осознавая, что на их рабочее место претендуют тысячи уволенных, готовы работать за меньшую заработную плату. Таким образом, сам факт сохранения рабочего места сотруднику рассматривается как мотивация к более качественной и эффективной работе.

Но проблема заключается в том, что в условиях окружающей нестабильности и многочисленных сокращений сотрудников в большинстве областях экономики персонал оказался немотивирован. По данным Росстата РФ, число безработных в нашей стране к сентябрю 2016 г. составила 4,0 млн. человек (не изменившись по отношению к сентябрю 2015 г. - 4,0 млн. чел.), что составляет 5,2\% экономически активного населения. Так, процесс мотивации персонала в условия х кризиса следует модернизировать как в системе материального, так и нематериального стимулирования [3].

Главную роль в трудовой мотивации работников играет материальное вознаграждение, причем оно не должно выступать, только компенсацией времени, сил, интеллекта, которые тратятся работником в процессе достижении целей организации. Различные денежные вознаграждения, размеры и формы их получения работник будет воспринимать как доказательство того, что он ценен для организации, что существенно повлияет на его самооценку, повысит его заинтересованность и эффективность труда [5. С.12].

В условиях кризиса внутри личностная мотивация сотрудников подвергается изменениям.

Начинает доминировать мотивация избегания неудач, страх лишиться работы, уменьшение заработка. В таких случаях материальное стимулирование сотрудников должно осуществляться в соответствии со следующими принципами:
1. Следование такой тенденций, как переход от оплаты труда к оплате результата. При сокращении фиксированной части дохода, сотруднику следует предоставлять возможность зарабатывать больше посредством достижения целей, которые преследует компания. Такая зависимость заработной платы от результата повышает его заинтересованность и ответственность в достижении высших показателей работы предприятия, способствует более эффективному решению различного рода задач, расширяет уровень знаний [3. С. 53].

2. Своевременное информирование и разъяснение всем сотрудникам их личные цели, которые непосредственно напрямую связанны с целями и миссией бизнеса.

3. Донесение до всех сотрудников, из чего складывается их доход, за что они теперь получают вознаграждение.

Если руководитель замечает старание и каждое проявление активности работником и его поощряет, то его заинтересованность в работе соответственно повышается, их труд становится более результативным, а предприятие получает большую прибыль. Также, нельзя забывать о том, что материальное стимулирование должно быть выгодно как организации, так и самому сотруднику. Вследствие этого, следует учитывать правило, что сумма всех премиальных выплат при любом значении перевыполнения плановых показателей не может превышать сумму прибыли, полученной в результате применения данной системы.

4. Регулярный контроль результатов, достигнутых сотрудниками в форме отчетов, коллективных собраний, совещаний и др. Система материального стимулирования должна стимулировать сотрудников на достижение целей, поставленных руководством компании. При этом 
поставленные цели должны быть достаточно сложными, но достижимыми, в ином случае можно спровоцировать обратный эффект, и персонал может быть демотивирован.

Система мотивации персонала не будет достаточно эффективной, если она будет основываться только на материальных факторах (таких как зарплата, премии, поощрения) и не включать нематериальные мотивы. Ведь повысив заработную плату, сотрудники начнут привыкать к этому, и рано или поздно такая мера перестанет давать отдачу, на которую рассчитывает руководство компании. Более того, неоправданно завышенная зарплата начинает оказывать демотивирующее воздействие: зачем работать хорошо, когда можно работать плохо и зарабатывать больше?

К тому же из-за финансовых трудностей в период кризиса для большинства предприятий увеличение материальных вознаграждений для поощрения сотрудников «становится непозволительной роскошью». В связи с этим рациональное осуществление нематериальной мотивации позволит компании укрепить лояльность сотрудников, повысить их интерес к собственному профессионализму, уменьшить панические настроения в коллективе и, как следствие, повысить качество их профессионально й деятельности [6, С. 223].

Существуют различные

методы

нематериальной мотивации: доски и книги почета, гимны и флаги, конкурсы и переходящие кубки, памятные знаки, рейтинги, корпоративные мероприятия, устные поощрения и т. д. К тому же эффективны и психологические правила мотивации: уважение личности, искренняя в похвала, возможности для роста, поощрение групповой работы и сотрудничества и т.д. [7, 8].

В условиях кризиса также действенным орудием нематериальной мотивации персонала служит корпоративная культура.

Активность руководителя, создание боевого духа команды в период кризиса являются важнейшими условиями для осуществления успешного антикризисного управления . Встанут ли люди рядом со своими лидерами, останутся ли они преданны своему делу, сохранят ли они веру в успех - зависит от того, какой стиль управления будет выбран управляющей командой [8].

Важной составляющей

корпоратив но й культуры компании служит миссия компании. Она представляющая собой цель высокого уровня обобщения, отвечающая на вопрос: зачем нужна людям эта организация?

Формулирование миссии организации - это процесс коллективный.

Руководство, позволяющее персоналу участвовать в решении серьезных вопросов, получает цель, которая действительно учитывает ценности организации, а так же повышает интерес, мотивацию персонала. Персонал компании в таком случаи будет работать более усердно, так как к ним прислушивается руководство.

Четкое определение ценностей в формулировании миссии организации, позволяет привлечь людей с общими интересами, целями и ценностями. Так, процесс подбора персонала становиться проще, он более управляемый.

Если у компании уже сформулирована миссия, то в период кризиса ее необходимо дополнить, показать положительный настрой и уверенность руководства.

В периоды кризиса, компании не следует отказываться от корпоративных мероприятий. Просто провести их более экономично или же дать возможность персоналу проявить себя с творческой стороны и организовать "бюджетный праздник". Это очень важное составляющее, которое поднимает настроение, командный дух, объединяет 
коллектив в единое целое.

Кроме этого, не стоит забывать, что каждому человеку приятно, когда его труд ценится. То есть, руководству для нематериальной мотивации нужно поощрять сотрудников устно и письменно. Это: благодарности, грамоты, публичное признание заслуг и т.д. Bce это влияет на работоспособность и заинтересованность в продвижении вверх. Так же необходимо помнить, что чрезмерная похвала определенного человека, может демотивировать другого.

В кризисной ситуации руководство должно иметь разработанную стратегию, план действий выхода из сложившегося положения. Очень важно предоставить эту информацию персоналу, внести определенность и объяснить, насколько важна их задача. В противном случае, сотрудники не будут знать, что компания находится в кризисном положении, и не будут прилагать максимум усилий для решения проблем.

Кроме информирования важным является вовлечение персонала в процесс принятия решений, особенно тех, которые их касаются. Так руководство показывает, что мнение сотрудников важно и имеет большое значение. Ведь именно они находятся в лучшем положении для того, чтобы видеть самое оптимальное решение возникающих проблем. Поскольку

персонал непосредственно осуществляет производственный процесс и общается с потребителями. Таким образом, вовлечение сотрудников в процесс принятия решений очень важно, они способствуют качественному решению данных проблем.

В большинстве случаев, руководители не спрашивают мнение сотрудников, а если и спрашивают, то не берут в счет. Вовлечение же работников увеличивает их обязательства перед организацией и в то же самое время помогает упростить осуществление новой идеи организационных изменений, так как сотрудники понимают смысл перемен и поддерживают их.

Руководитель должен ежемесячно, а если необходимо и еженедельно общаться с сотрудниками, пока компания находится в кризисной ситуации. Обсуждать какие меры приняты, что подействовало, что нет. Выявить все плюсы и минусы, прислушиваясь к мнению персонала решить все возникающие проблемы. Регулярное информирование коллектива о том, что антикризисные меры и совместная работа приносят результаты, мотивирует людей на преодоление сложностей.

\section{ЛИТЕРАТУРА}

1. Гаги, В.А. Экономика и социология труда (социально-трудовые отношения // Учеб. пособие. - М.: Том. ун-та, 2013. - 340 с.

2. Львов, С. Незаменимые люди есть // Интернетжурнал «Управления компанией», 2013. № 5 [Электронный ресурс]. - Режим доступа: http://www.ckfin.ru/press/zhuk.shtml.

3. МОТ: статистика безработных за 2016г. [Электронный ресурс]. - Режим доступа: http://www.newsru.com/finance/27ian2016/mot.html.

4. Пустынникова, Ю. Система мотивации персонала в торговых компаниях [Электронный ресурс]. - Режим доступа: http://www.ippnou.ru/article.php?idarticle=000168 .

5. Сосновый, А. Разработка внутрифирменных систем оплаты труда, мотив ации и стимулирования персонала // Справочник по управлению персоналом, 2014. № 1. C.49-60. 
6. Самоукина, Н.В. Эффективная мотивация персонала. - М.: Вершина, 2014. - 224 с.

7. Управление персоналом в условиях кризиса // рекомендации для руководителя [Электронный ресурс]. - Режим доступа: http://samoukina.ru/press/press42.shtml.

8. Хайем, А. 17 способов повысить мотивацию сотрудников [Электронный ресурс].Режим

http://webinary.com.ua/publ/stati_sfery_hrm/17_sposobov_povysit_motivaciju_sotrudni kov/3-1-0-63.

9. Шелехова, Л.В. Особенности мотивации персонала в условиях кризиса / Л.В. Шелехова, В.Макаревич // сборник научных трудов по материалам II Всероссийской научно-практической конференции «Проблемы и перспективы социально-экономического развития регионов Юга России».- Майкоп: Изд-во АГУ, 2015.- С. 384-388. 


\title{
ТЕКСТОВОЕ ЭЛЕКТРОННОЕ ИЗДАНИЕ
}

НАУЧНОЕ ИЗДАНИЕ

\section{ПРОБЛЕМЫ И ПЕРСПЕКТИВЫ СОЦИАЛЬНО-ЭКОНОМИЧЕСКОГО РАЗВИТИЯ РЕГИОНОВ ЮГА РОССИИ}

СБОРНИК НАУЧНЫХ ТРУДОВ

\author{
по материалам \\ III Всероссийской \\ научно-практической \\ конференции
}

